Prepared in cooperation with the Oregon Water Resources Department

\title{
Ground-Water Hydrology of the Upper Klamath Basin, Oregon and California
}
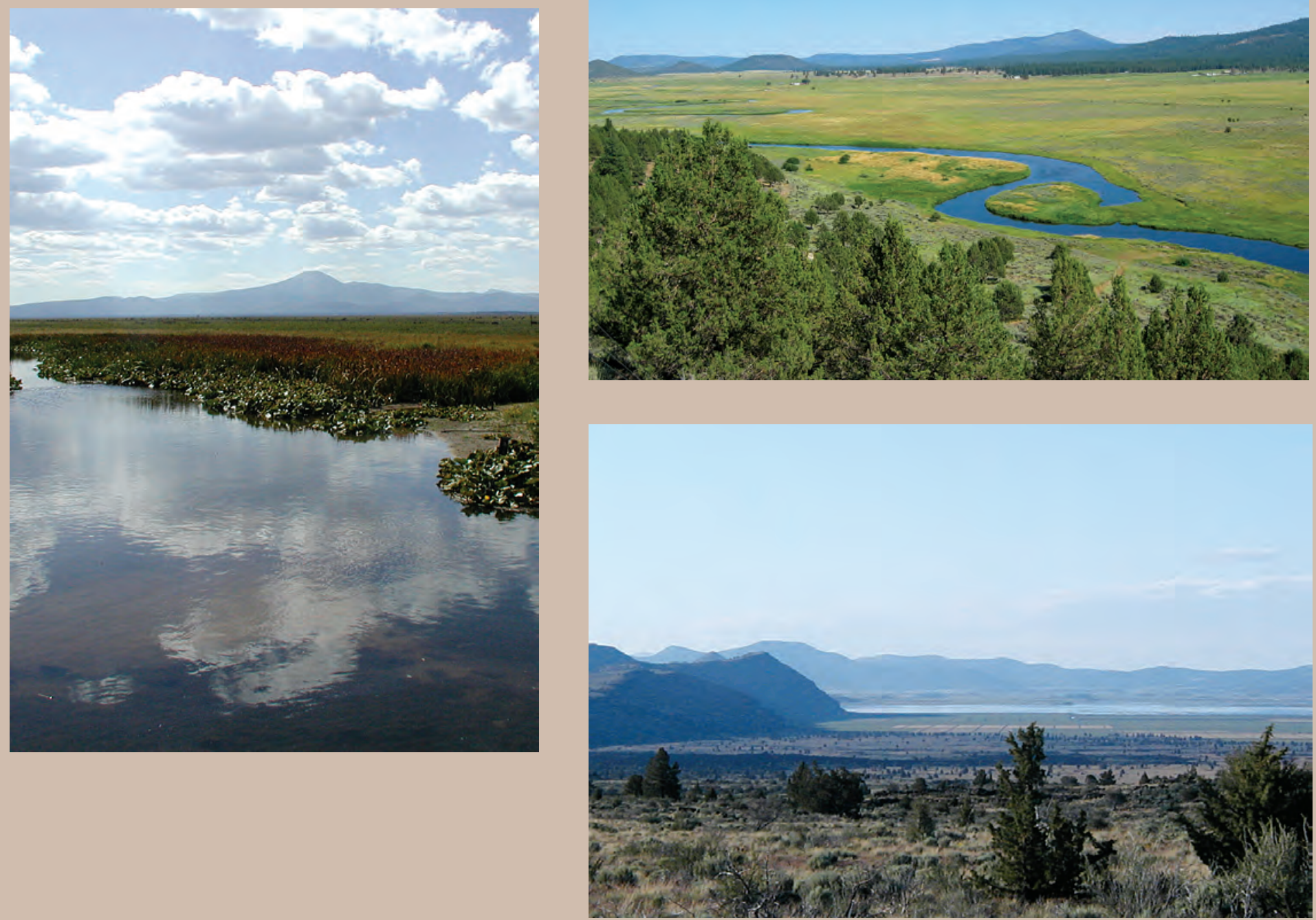

Scientific Investigations Report 2007-5050

Version 1.1, April 2010

U.S. Department of the Interior

U.S. Geological Survey 
Cover: Left, Klamath Marsh at Military Crossing, looking west, (photograph by Marshall Gannett); upper right, Sprague River Valley from Knot Tableland, looking southeast (photograph by Kenneth Lite); lower right, Sheepy Ridge (on the left) and the Tule Lake subbasin from Lava Beds National Monument, looking north (photograph by Marshall Gannett). 


\section{Ground-Water Hydrology of the Upper Klamath Basin, Oregon and California}

By Marshall W. Gannett, Kenneth E. Lite Jr., Jonathan L. La Marche, Bruce J. Fisher, and Danial J. Polette

Prepared in cooperation with the Oregon Water Resources Department

Scientific Investigations Report 2007-5050

Version 1.1, April 2010 


\section{U.S. Department of the Interior DIRK KEMPTHORNE, Secretary}

\section{U.S. Geological Survey \\ Mark D. Myers, Director}

U.S. Geological Survey, Reston, Virginia: 2007

Revised: 2010

For product and ordering information:

World Wide Web: http://www.usgs.gov/pubprod

Telephone: 1-888-ASK-USGS

For more information on the USGS--the Federal source for science about the Earth, its natural and living resources, natural hazards, and the environment:

World Wide Web: http://www.usgs.gov

Telephone: 1-888-ASK-USGS

Any use of trade, product, or firm names is for descriptive purposes only and does not imply endorsement by the U.S. Government.

Although this report is in the public domain, permission must be secured from the individual copyright owners to reproduce any copyrighted materials contained within this report.

Suggested citation:

Gannett, M.W., Lite, K.E. Jr., La Marche, J.L., Fisher, B.J., and Polette, D.J., 2007, Ground-water hydrology of the upper Klamath Basin, Oregon and California: U.S. Geological Survey Scientific Investigations Report 2007-5050, 84 p. 


\section{Contents}

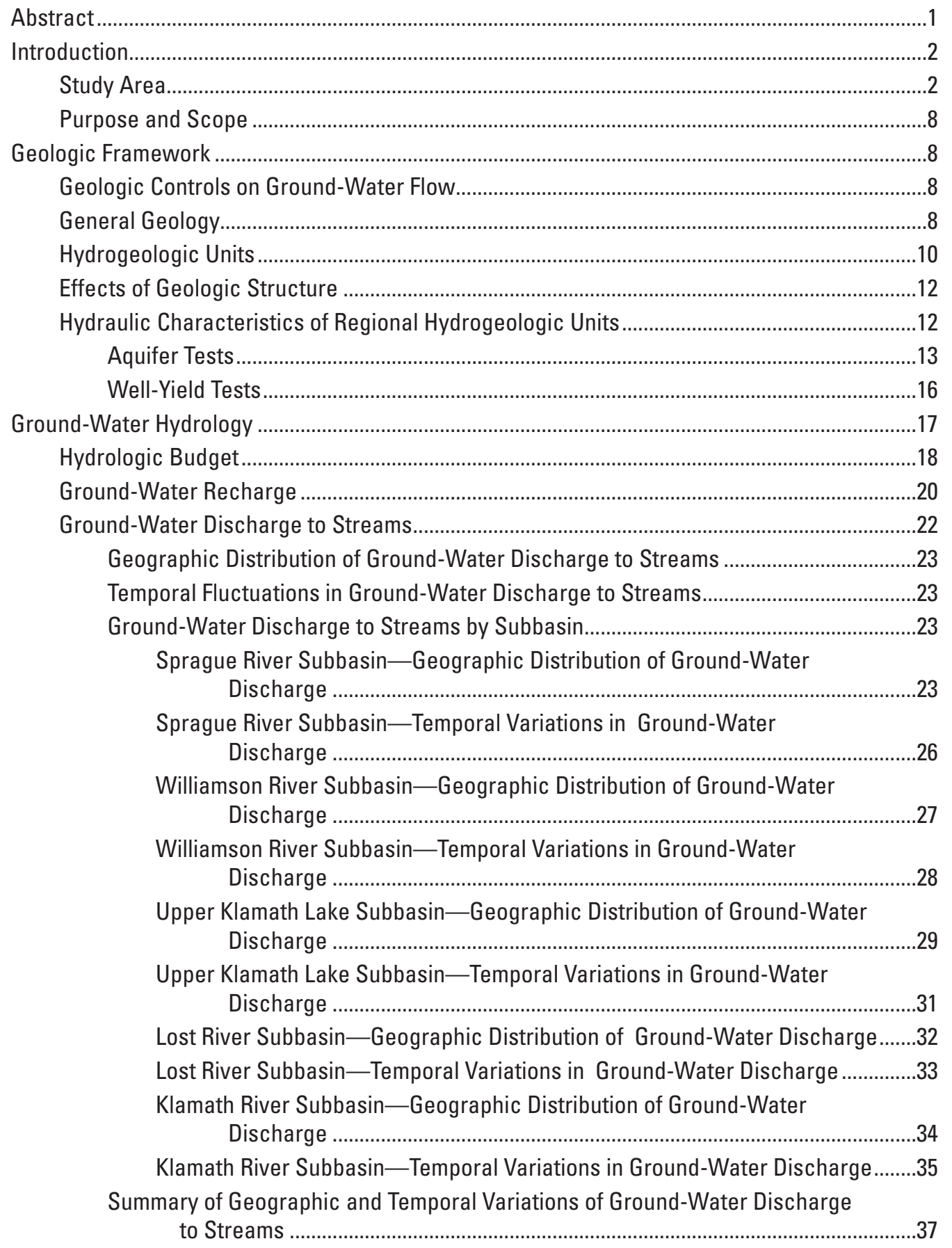




\section{Contents-Continued}

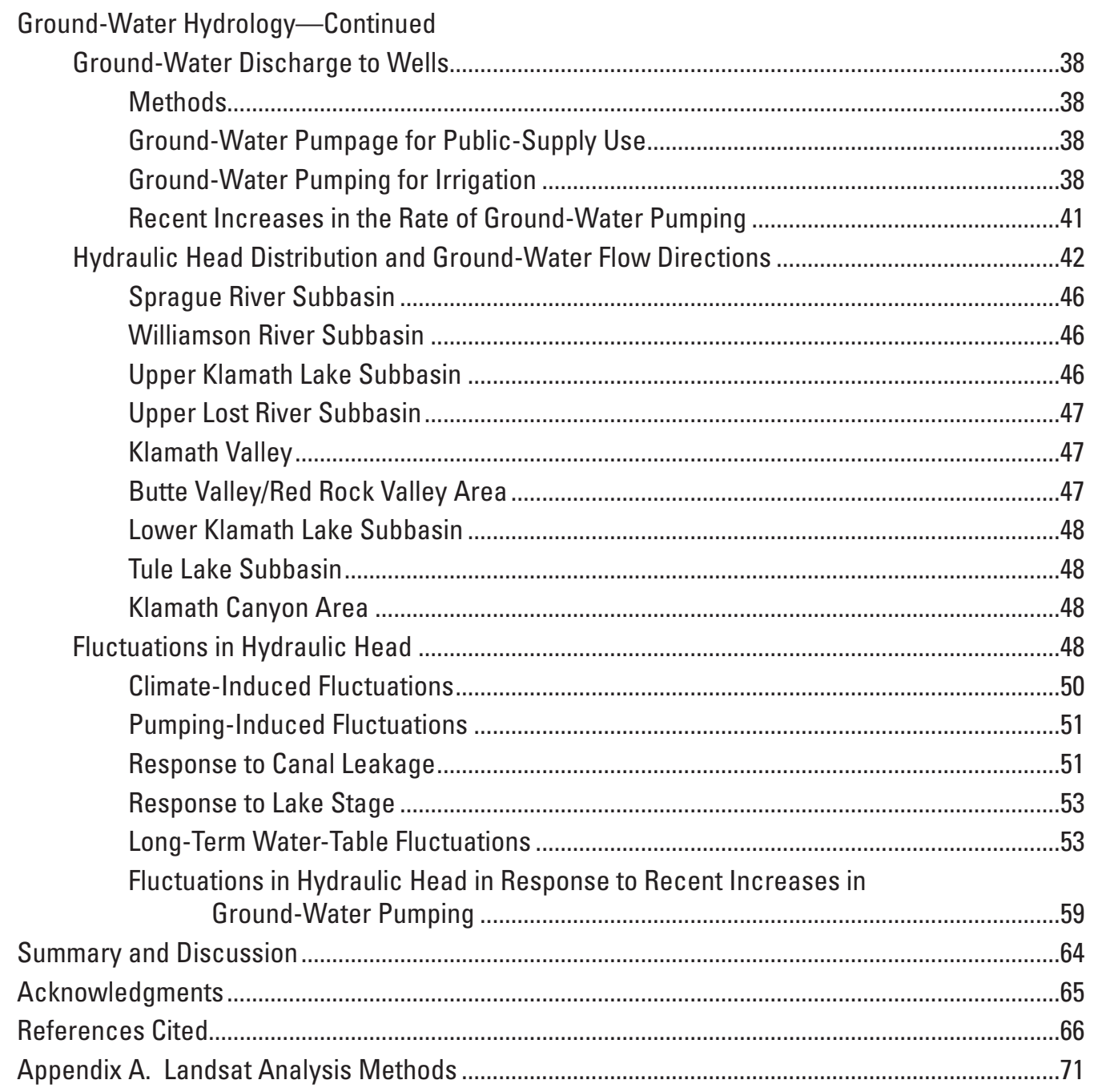




\section{Figures}

Figure 1. Map showing the upper Klamath Basin, Oregon and California, and major

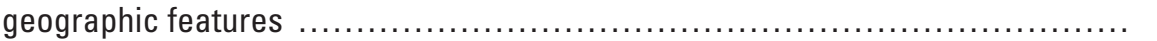

Figure 2. Map showing distribution of precipitation in the upper Klamath Basin, Oregon and California, and mean monthly precipitation at selected precipitation measurement stations

Figure 3. Map showing irrigated areas in the Bureau of Reclamation Klamath Project, Oregon and California

Figure 4. Map showing hydrogeologic units of the upper Klamath Basin, Oregon and California 11

Figure 5. Graph showing cumulative distribution of transmissivity values estimated from specific-capacity tests for wells producing from Quaternary sediment, Tertiary sedimentary rock, and Tertiary volcanic rock in the upper Klamath Basin, Oregon and California

Figure 6. Schematic representation of sources of ground-water recharge, flow paths, and mechanisms of ground-water discharge in the upper Klamath Basin, Oregon and California

Figure 7. Map showing principal areas of ground-water discharge to streams and major springs in the upper Klamath Basin, Oregon and California, and selected stream-gaging stations

Figure 8. Graph showing annual precipitation at Crater Lake National Park, Oregon, and the cumulative departure from average precipitation from 1932 to 2005

Figure 9. Graph showing september mean discharge of the Sprague River near Chiloquin, Oregon (USGS gaging station number 11501000), and the cumulative departure from average precipitation at Crater Lake, Oregon

Figure 10. Graph showing monthly mean discharge and September mean discharge of the Williamson River below Sheep Creek near Lenz, Oregon (USGS gaging station number 11491400), and the cumulative departure from average precipitation at Crater Lake, Oregon

Figure 11. Graph showing relation between the September mean discharge of the Williamson River below Sheep Creek near Lenz, Oregon (USGS gaging station number 11491400), and the cumulative departure from average precipitation at Crater Lake, Oregon

Figure 12. Graph showing discharge measurements of Spring Creek, estimated ground-water discharge to the lower Williamson River between Kirk and Chiloquin, and cumulative departure from average precipitation at Crater Lake, Oregon

Figure 13. Graph showing monthly mean discharge and January to March mean discharge of Annie Spring near Crater Lake, Oregon (USGS gaging station number 11503000), and the cumulative departure from average precipitation at Crater Lake 


\section{Figures-Continued}

Figure 14. Graph showing discharge of the Wood River as measured or estimated at various sites, and the cumulative departure from average precipitation at Crater Lake, Oregon

Figure 15. Graph showing discharge of Bonanza Springs and cumulative departure from average precipitation at Crater Lake, Oregon

Figure 16. Graph showing August mean gains in flow (a proxy for ground-water discharge) between Keno (USGS gaging station number 11509500) and the John C. Boyle power plant (11510700), estimates of inflow by PacifiCorp, and the cumulative departure from average precipitation at Crater Lake, Oregon

Figure 17. Graph showing September to November mean gains in flow (a proxy for ground-water discharge) between the John C. Boyle power plant (USGS station number 11510700) and Iron Gate Dam (11516530), and the cumulative departure from average precipitation at Crater Lake, Oregon

Figure 18. Map showing areas irrigated with ground water in the upper Klamath Basin, Oregon and California, during the $\mathbf{2 0 0 0}$ water year, and areas with primary ground-water irrigation rights in Oregon

Figure 19. Graph showing growth in total acreage with ground-water irrigation rights (primary and supplemental) in the upper Klamath Basin in Oregon through 2005

Figure 20. Maps showing distribution of ground-water pumping for the Bureau of Reclamation pilot water bank during water years 2003 and 2004, upper Klamath Basin, Oregon and California

Figure 21. Map showing generalized water-level contours and approximate directions of regional ground-water flow in the upper Klamath Basin, Oregon and California

Figure 22. Map showing selected observation wells in the upper Klamath Basin, Oregon and California

Figure 23. Graph showing water-level fluctuations in well 30S/07E-06AAA near Bear Creek northeast of Crater Lake, Oregon

Figure 24. Graph showing water-level fluctuations in well 36S/14E-25BCB near Bly and the cumulative departure from average precipitation at Crater Lake, Oregon

Figure 25. Graph showing water-level fluctuations in well 35S/12E-26DCD north of Beatty, Oregon

Figure 26. Graph showing water-level fluctuations in well 40S/12E-32CDB northwest of Malin, Oregon

Figure 27. Graph showing water-level fluctuations in well 40S/09E-28ADB on the southwest side of the Klamath Hills, Oregon, and monthly discharge in the nearby North Canal

Figure 28. Graph showing water-level fluctuations in shallow and deep water-bearing zones in double-completion well 39S/12E-35ABB near Lorella, Oregon

Figure 29. Graph showing water-level fluctuations in shallow and deep water-bearing zones in double-completion well 39S/12E-35ABB near Lorella, Oregon, with time scale expanded to show effects of nearby ground-water pumping 


\section{Figures-Continued}

Figure 30. Graph showing water-level fluctuations in well 35S/06E-10ACC near Pelican

Butte and stage in Upper Klamath Lake, Oregon 55

Figure 31. Graph showing water-level fluctuations in well 38S/09E-17CBC in the north part of Klamath Falls and stage in Upper Klamath Lake, Oregon

Figure 32. Graphs showing water-level fluctuations in wells 36S/14E-25BCB near Bly, $39 \mathrm{~S} / 11 \mathrm{E}-20 \mathrm{AAD}$ near Bonanza, and 41S/14E-08CCA in the southern Langell Valley, Oregon

Figure 33. Graphs showing water-level fluctuations in wells 36S/10E-14ACC and 36S/11E-20DCA in the Sprague River Valley, Oregon

Figure 34. Graph showing water-level fluctuations in well 46N/01E-06N01 in Butte Valley, California

Figure 35. Graphs showing water-level fluctuations in wells 40S/11E-11BAD in the southern Poe Valley and well 40S/12E-30DCB north of Malin, Oregon

Figure 36. Graphs showing water-level fluctuations in wells 39S/11E-26ABD and $39 \mathrm{~S} / 12 \mathrm{E}-35 \mathrm{ADD}$ in the western Langell Valley, Oregon

Figure 37. Graph showing water-level fluctuations in well 41S/09E-12AAB at the southern end of the Klamath Hills, Oregon

Figure 38. Map showing water-level decline between spring and fall 2004 in the Klamath Valley and Tule Lake areas, upper Klamath Basin, Oregon and California $\quad \ldots . . . .61$

Figure 39. Graph showing water-level fluctuations in well 48N/04E-35L02 near the town of Tulelake, California

Figure 40. Map showing water-level decline between spring 2001 and spring 2004 in the Klamath Valley and Tule Lake areas, Oregon and California

\section{Tables}

Table 1. Generalized hydrogeologic units in the upper Klamath Basin, Oregon and California

Table 2. Summary of selected aquifer tests, upper Klamath Basin, Oregon and California

Table 3. Estimates of major hydrologic budget elements of the upper Klamath Basin, Oregon and California

Table 4. Estimated ground-water pumping for irrigation in the upper Klamath Basin, Oregon and California, during water year 2000

Table 5. Ground-water pumping for the Bureau of Reclamation pilot water bank and ground-water acquisition program, upper Klamath Basin, Oregon and California

Table 6. Estimated ground-water discharge to principal stream reaches in the upper Klamath Basin, Oregon and California 


\title{
Conversion Factors and Datums
}

\author{
Conversion Factors
}

\begin{tabular}{|c|c|c|}
\hline Multiply & By & To obtain \\
\hline acre & 0.004047 & square kilometer $\left(\mathrm{km}^{2}\right)$ \\
\hline acre-foot (acre-ft) & 1,233 & cubic meter $\left(\mathrm{m}^{3}\right)$ \\
\hline acre-foot per year (acre-ft/yr) & 1,233 & cubic meter per year $\left(\mathrm{m}^{3} / \mathrm{yr}\right)$ \\
\hline cubic foot $\left(\mathrm{ft}^{3}\right)$ & 0.02832 & cubic meter $\left(\mathrm{m}^{3}\right)$ \\
\hline cubic foot per second $\left(\mathrm{ft}^{3} / \mathrm{s}\right)$ & 0.02832 & cubic meter per second $\left(\mathrm{m}^{3} / \mathrm{s}\right)$ \\
\hline $\begin{array}{l}\text { cubic foot per second per mile } \\
{\left[\left(\mathrm{ft}^{3} / \mathrm{s}\right) / \mathrm{mi}\right]}\end{array}$ & 0.0176 & $\begin{array}{l}\text { cubic meter per second per kilometer } \\
{\left[\left(\mathrm{m}^{3} / \mathrm{s}\right) / \mathrm{km}\right]}\end{array}$ \\
\hline foot $(\mathrm{ft})$ & 0.3048 & meter $(\mathrm{m})$ \\
\hline foot per day (ft/d) & 0.3048 & meter per day $(\mathrm{m} / \mathrm{d})$ \\
\hline foot per mile $(\mathrm{ft} / \mathrm{mi})$ & 0.1894 & meter per kilometer $(\mathrm{m} / \mathrm{km})$ \\
\hline foot squared per day $\left(\mathrm{ft}^{2} / \mathrm{d}\right)$ & 0.09290 & meter squared per day $\left(\mathrm{m}^{2} / \mathrm{d}\right)$ \\
\hline gallon (gal) & 3.785 & liter $(\mathrm{L})$ \\
\hline gallon per day per foot $[(\mathrm{gal} / \mathrm{d}) / \mathrm{ft}]$ & 0.01242 & $\begin{array}{l}\text { cubic meter per day per meter } \\
{\left[\left(\mathrm{m}^{3} / \mathrm{d}\right) / \mathrm{m}\right]}\end{array}$ \\
\hline gallon per minute (gal/min) & 0.06309 & liter per second $(\mathrm{L} / \mathrm{s})$ \\
\hline inch (in.) & 2.54 & centimeter $(\mathrm{cm})$ \\
\hline inch per year (in/yr) & 25.4 & millimeter per year $(\mathrm{mm} / \mathrm{yr})$ \\
\hline mile (mi) & 1.609 & kilometer $(\mathrm{km})$ \\
\hline million gallons (Mgal) & 3,785 & cubic meter $\left(\mathrm{m}^{3}\right)$ \\
\hline million gallons per day (Mgal/d) & 0.04381 & cubic meter per second $\left(\mathrm{m}^{3} / \mathrm{s}\right)$ \\
\hline square foot $\left(\mathrm{ft}^{2}\right)$ & 0.09290 & square meter $\left(\mathrm{m}^{2}\right)$ \\
\hline square mile $\left(\mathrm{mi}^{2}\right)$ & 2.590 & square kilometer $\left(\mathrm{km}^{2}\right)$ \\
\hline
\end{tabular}

Temperature in degrees Fahrenheit $\left({ }^{\circ} \mathrm{F}\right)$ may be converted to degrees Celsius $\left({ }^{\circ} \mathrm{C}\right)$ as follows:

$$
{ }^{\circ} \mathrm{C}=\left({ }^{\circ} \mathrm{F}-32\right) / 1.8 \text {. }
$$

Datums

Horizontal coordinate information is referenced to the North American Datum of 1927 (NAD 27).

Vertical coordinate information is referenced to the National Geodetic Vertical Datum of 1929 (NGVD 29). In this report, "altitude" refers to the distance above the vertical datum.

*Transmissivity: The standard unit for transmissivity is cubic foot per day per square foot times foot of aquifer thickness [(ft $\left.\left.\mathrm{ft}^{3} / \mathrm{d}\right) / \mathrm{ft}^{2}\right] \mathrm{ft}$. In this report, the mathematically reduced form, foot squared per day $\left(\mathrm{ft}^{2} / \mathrm{d}\right)$, is used for convenience. 


\section{Location System}

The system used for locating wells and springs in this report is based on the rectangular system for subdivision of public land. The States of Oregon and California are divided into 36 squaremile townships numbered according to their location relative to an east-west baseline and a north-south meridian. In Oregon, the Willamette base line and meridian are used, and in California, the Mount Diablo baseline and meridian are used. The position of a township is given by its north-south "Township" position relative to the baseline and its east-west "Range" position relative to the meridian. Each township is divided into 36 sections approximately 1 square mile (640-acre) in area and numbered from 1 to 36. For example, a well designated as 36S/11E20DCA is located in Township 36 south, Range 11 east, section 20. The three letters following the section number $(A, B, C$, or D) correspond to the location within the section; the first letter identifies the quarter section (160 acres), the second letter identifies the quarter-quarter section (40 acres), and the third letter identifies the quarter-quarter-quarter section (10 acres). Thus, well 20DCA is located in the NE quarter of the SW quarter of the SE quarter of section 20. When more than one designated well occurs in the quarter-quarter-quarter section, a serial number is appended. For some wells that were field located during previous studies or by the California Department of Water Resources, a different system of letters following the section number was used for the location within the section. This system assigns a letter to one of 16 quarter-quarter sections (40 acres) that divide the section. The location 20DCA corresponds to the location 20Q. When more than one designated well occurs in the quarter-quarter section, a serial number is appended.

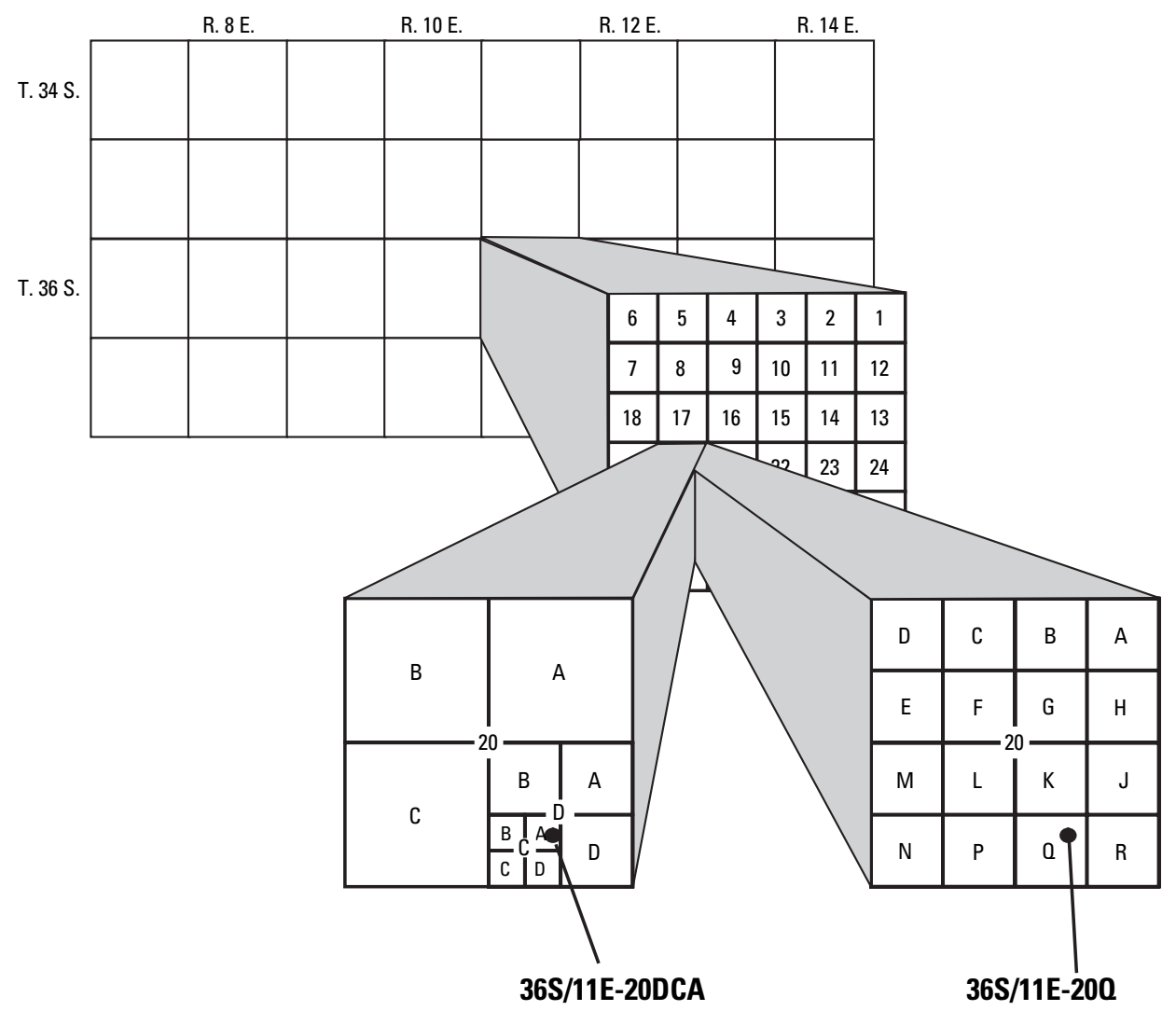




\section{Mapping Sources}

Base modified from U.S. Geological Survey 1:100,000 and 1:24,000 scale quadrangle maps. Relief from U.S. Geological Survey National Elevation Data Set 30 meter digital elevation model. Klamath Reclamation Project boundaries are from Bureau of Reclamation, Klamath Basin Area Office GIS data.

Vertical datum: National Geodetic Vertical Datum of 1929 (NGVD29)

Projection: Universal Transverse Mercator, Zone 10, 1927 North American Datum Ground-Water Hydrology of the Upper Klamath Basin, Oregon and California 


\title{
Ground-Water Hydrology of the Upper Klamath Basin, Oregon and California
}

\author{
By Marshall W. Gannett, Kenneth E. Lite Jr., Jonathan L. La Marche, Bruce J. Fisher, and Danial J. Polette
}

Abstract

The upper Klamath Basin spans the California-Oregon border from the flank of the Cascade Range eastward to the Basin and Range Province, and encompasses the Klamath River drainage basin above Iron Gate Dam. Most of the basin is semiarid, but the Cascade Range and uplands in the interior and eastern parts of the basin receive on average more than 30 inches of precipitation per year. The basin has several perennial streams with mean annual discharges of hundreds of cubic feet per second, and the Klamath River at Iron Gate Dam, which represents drainage from the entire upper basin, has a mean annual discharge of about 2,100 cubic feet per second. The basin once contained three large lakes: Upper and Lower Klamath Lakes and Tule Lake, each of which covered areas of 100 to 150 square miles, including extensive marginal wetlands. Lower Klamath Lake and Tule Lake have been mostly drained, and the former lake beds are now cultivated. Upper Klamath Lake remains, and is an important source of irrigation water. Much of the wetland surrounding Upper Klamath Lake has been diked and drained, although efforts are underway to restore large areas. Upper Klamath Lake and the remaining parts of Lower Klamath and Tule Lakes provide important wildlife habitat, and parts of each are included in the Klamath Basin National Wildlife Refuges Complex.

The upper Klamath Basin has a substantial regional ground-water flow system. The late Tertiary to Quaternary volcanic rocks that underlie the region are generally permeable, with transmissivity estimates ranging from 1,000 to 100,000 feet squared per day, and compose a system of variously interconnected aquifers. Interbedded with the volcanic rocks are late Tertiary sedimentary rocks composed primarily of fine-grained lake sediments and basin-filling deposits. These sedimentary deposits have generally low permeability, are not good aquifers, and probably restrict ground-water movement in some areas. The regional groundwater system is underlain and bounded on the east and west by older Tertiary volcanic and sedimentary rocks that have generally low permeability. Eight regional-scale hydrogeologic units are defined in the upper Klamath Basin on the basis of surficial geology and subsurface data.
Ground water flows from recharge areas in the Cascade Range and upland areas in the basin interior and eastern margins toward stream valleys and interior subbasins. Ground water discharges to streams throughout the basin, and most streams have some component of ground water (baseflow). Some streams, however, are predominantly ground-water fed and have relatively constant flows throughout the year. Large amounts of ground water discharge in the Wood River subbasin, the lower Williamson River area, and along the margin of the Cascade Range. Much of the inflow to Upper Klamath Lake can be attributed to ground-water discharge to streams and major spring complexes within a dozen or so miles from the lake. This large component of ground water buffers the lake somewhat from climate cycles. There are also ground-water discharge areas in the eastern parts of the basin, for example in the upper Williamson and Sprague River subbasins and in the Lost River subbasin at Bonanza Springs.

Irrigated agriculture is an integral part of the economy of the upper Klamath Basin. Although estimates vary somewhat, roughly 500,000 acres are irrigated in the upper Klamath Basin, about 190,000 acres of which are part of the Bureau of Reclamation Klamath Project. Most of this land is irrigated with surface water. Ground water has been used for many decades to irrigate areas where surface water is not available, for example outside of irrigation districts and stream valleys. Ground water has also been used as a supplemental source of water in areas where surface water supplies are limited and during droughts. Ground water use for irrigation has increased in recent years due to drought and shifts in surfacewater allocation from irrigation to instream uses. The shifts in surface-water allocation have resulted from efforts to improve habitat for fish listed under the Federal Endangered Species Act.

The ground-water system in the upper Klamath Basin responds to external stresses such as climate cycles, pumping, lake stage variations, and canal operation. This response is manifest as fluctuations in hydraulic head (as represented by fluctuations in the water-table surface) and variations in ground-water discharge to springs. Basinwide, decadal-scale climate cycles are the largest factor controlling head and discharge fluctuations. Climate-driven water-table fluctuations of more than 12 feet have been observed near the Cascade 
Range, and decadal-scale fluctuations of 5 feet are common throughout the basin. Ground-water discharge to springs and streams varies basinwide in response to decadal-scale climate cycles.

The response of the ground-water system to pumping is generally largest in areas where pumping occurs. Annual drawdown and recovery cycles of 1 to 10 feet are common in pumping areas. Long-term drawdown effects, where the water table has reached or is attempting to reach a new level in equilibrium with the pumping, are apparent in parts of the basin.

Since 2001, ground-water use in the upper Klamath Basin has increased by about 50 percent. Much of this increase has occurred in the area in and around the Bureau of Reclamation Klamath Project, roughly tripling ground-water pumping in that area. This focused increase in pumping has resulted in ground-water level declines in the pumped aquifer in excess of 10 to 15 feet over a large part of the Project between 2001 and 2004. If pumping rates of recent years are continued, the aquifer could achieve a new equilibrium; however, the final configuration of the water table (depth to water) and the spatial and temporal distribution of the resulting effects to streams are unknown. Historical water-level data suggest that the water table should recover from recent declines if pumping is reduced to pre-2001 rates.

\section{Introduction}

The upper Klamath Basin spans the Oregon-California border from the flank of the Cascade Range eastward to the high desert. Although much of the basin is high desert, the region receives considerable runoff from the Cascade Range and uplands to the east. As a result, the area has numerous perennial streams, large shallow lakes, and extensive wetlands, and the Klamath River has historically supported anadromous fish runs. Water in the basin is used for agricultural irrigation, for extensive waterfowl refuges, and to support aquatic wildlife in lakes and streams in the upper basin and downstream.

The agricultural economy of the upper Klamath Basin relies on irrigation water. Just over 500,000 acres are irrigated in the upper Klamath Basin, about 190,000 acres of which are within the Klamath Project developed and operated by the Bureau of Reclamation (Reclamation) (Burt and Freeman, 2003; Natural Resources Conservation Service, 2004). The principal source of water for the Bureau of Reclamation Klamath Project is Upper Klamath Lake. In recent years, Endangered Species Act biological opinions have required Reclamation to maintain certain lake levels in Upper Klamath Lake to protect habitat for endangered fish (specifically the Lost River and shortnose suckers) and at the same time maintain specified flows in the Klamath River below the lake and project diversions to provide habitat for listed salmon.
This shift in water management has resulted in increased demands for water. Owing to the limitations of other options, the increased demand has resulted in increased use of ground water in the basin. The problems associated with increased demands are exacerbated by drought.

The upper Klamath Basin has a substantial regional ground-water system, and ground water traditionally has been used for irrigation for many decades in certain areas. The changes in water management described above coupled with a series of dryer than average years have resulted in an approximately 50 percent increase in ground-water pumping in the basin since 2001. Most of this increase is focused in the area of the Klamath Project. Increased pumping has caused local water-level declines that have been problematic for some ground-water users and generated concern among resource management agencies and the community. In addition to the measured effects, the basic principles of hydrology require that the volume of ground-water pumped and used consumptively must be offset by changes in flow to or from other boundaries including streams.

The effects of large-scale ground-water pumping can spread beyond the pumping centers to other parts of the regional ground-water system. Prior to this study, the groundwater hydrology had been studied only in separate parts of the basin, with many areas left undescribed. Therefore, there was no basic framework with which to understand the potential regional effects of ground-water development in the basin and the broad ramifications of water-management decisions. In 1999, the U.S. Geological Survey (USGS) and the Oregon Water Resources Department (OWRD) began a cooperative study to (1) quantitatively characterize the regional groundwater flow system in the upper Klamath Basin and (2) develop a computer model to simulate regional ground-water flow that can be used to help understand the resource and test management scenarios. This report summarizes efforts to quantitatively characterize the ground-water hydrology.

\section{Study Area}

The upper Klamath Basin (fig. 1) comprises the entire drainage basin above Iron Gate Dam, including the internally drained Lost River and Butte Creek subbasins, and encompasses about 8,000 $\mathrm{mi}^{2}$ (square miles). Studyarea boundaries were defined to correspond to hydrologic boundaries across which ground-water flow can be estimated or assumed negligible. The southwestern boundary near Iron Gate Dam was selected because it corresponds with the transition from a geologic terrane dominated by permeable volcanic rock to a terrane dominated by older rock with much lower permeability. It is not likely that significant regional ground-water flow crosses this geologic boundary. The boundary between the regional flow systems in the upper Klamath Basin and the Deschutes and Fort Rock Basins to the north (not shown on fig. 1) is defined by a surface-water divide that roughly corresponds to the ground-water divide. 


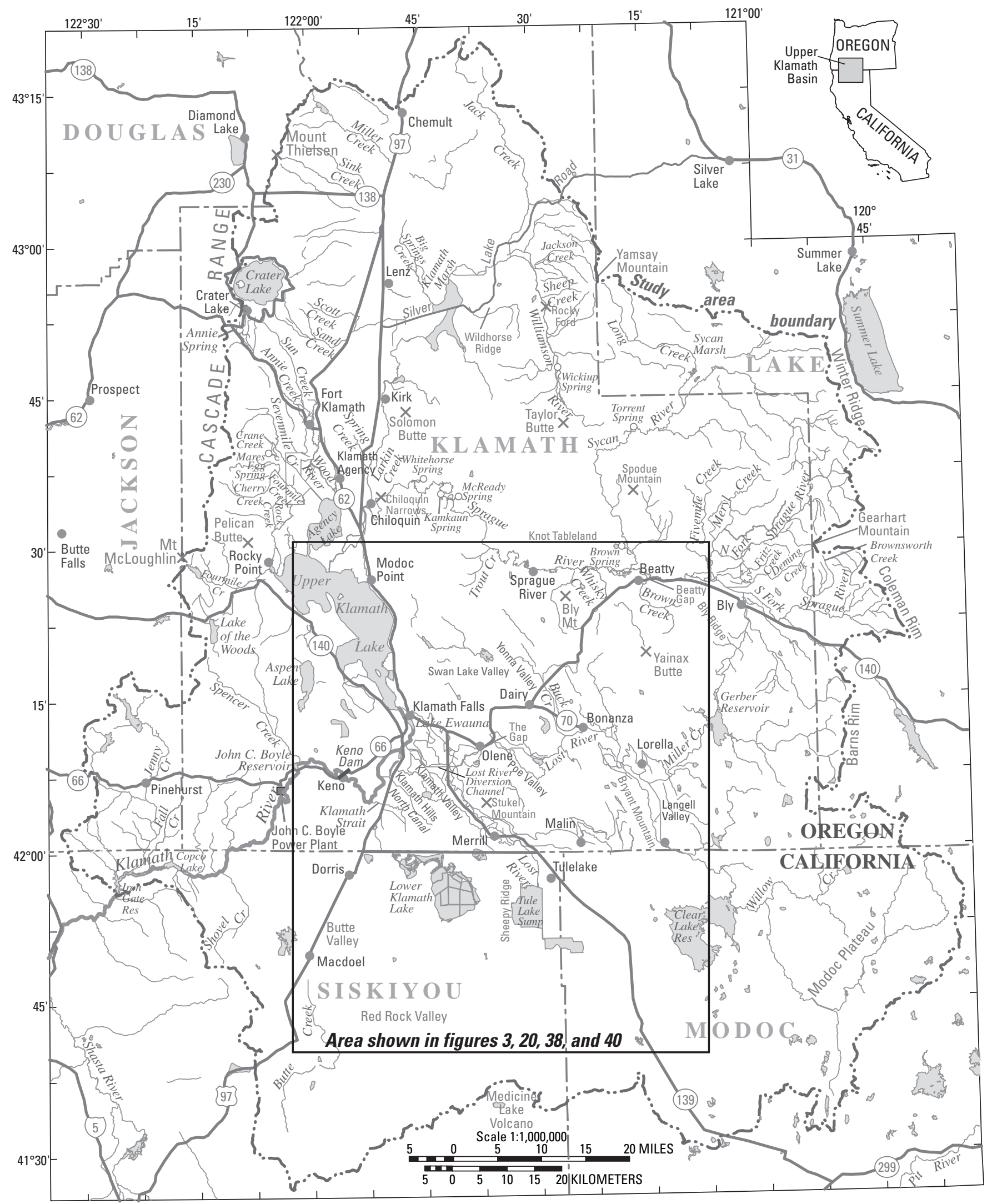

See table of contents for mapping sources

Figure 1. The upper Klamath Basin, Oregon and California, and major geographic features. 
This boundary is likely permeable. The boundary between the ground-water system of the upper Klamath Basin and that of the Pit River Basin to the south also is defined by a surfacewater divide in most places. The southern surface-water divide does not correspond to a ground-water divide in all places, as hydraulic head data indicate that there is southward flow of ground water from the upper Klamath Basin south of the Tule Lake subbasin toward the Pit River Basin. The eastern studyarea boundary corresponds to a surface-water divide and is characterized in many places by a transition to older geologic strata.

The upper Klamath Basin occupies a broad, faulted, volcanic plateau that spans the boundary between the Cascade Range and Basin and Range geologic provinces. The basin is bounded by the volcanic arc of the Cascade Range on the west, the Deschutes Basin to the north, the internally drained Silver Lake, Summer Lake, and Goose Lake Basins to the east, and the Pit River Basin to the south. The altitude of the Cascade Range along the western margin ranges from 5,000 to 7,000 ft (feet) with major peaks such as Mount McLoughlin and Mount Thielsen exceeding 9,000 ft. The interior parts of the basin are dominated by northwest-trending fault-bounded basins, typically several miles wide, with intervening uplands. Basin floors range in altitude from roughly 4,000 to $4,500 \mathrm{ft}$, and adjoining fault-block upland altitudes range from 4,500 to more than 5,000 ft. The northern and eastern parts of the upper Klamath Basin consist of a volcanic upland with numerous eruptive centers, including Yamsay and Gearhart Mountains, both of which exceed 8,000 ft. The southeastern margin of the upper Klamath Basin consists of a broad, rugged, volcanic upland known as the Modoc Plateau, where most of the land surface ranges from 4,500 to 5,000 ft. The southern margin of the basin is marked by the broad shield of Medicine Lake Volcano, which reaches an altitude of 7,913 ft.

The upper Klamath Basin is semiarid because the Cascade Range intercepts much of the moisture from the predominantly eastward moving Pacific weather systems. Mean annual precipitation (1961-90) ranges from 65.4 inches at Crater Lake National Park in the Cascade Range to 13.5 inches at Klamath Falls (fig. 2). Most precipitation occurs in the fall and winter. November through March precipitation accounts for 71 percent of the total at Crater Lake and 64 percent of the total at Klamath Falls. Most precipitation falls as snow at higher elevations. The interior parts of the basin are very dry during the spring and summer; mean monthly precipitation at Klamath Falls is less than 1 inch from April through October. Winters are generally cold, with January mean minimum and maximum temperatures of $20.3^{\circ} \mathrm{F}$ and $38.8^{\circ} \mathrm{F}$, respectively, at Klamath Falls and $17.5^{\circ} \mathrm{F}$ and $34.5^{\circ} \mathrm{F}$, respectively, at Crater Lake. Summers, in contrast, are warm, with July mean minimum and maximum temperatures of $50.8^{\circ} \mathrm{F}$ and $84.6^{\circ} \mathrm{F}$, respectively, at Klamath Falls and $39.8^{\circ} \mathrm{F}$ and $68.0^{\circ} \mathrm{F}$, respectively, at Crater Lake.

Principal streams in the upper Klamath Basin include the Williamson River, which drains the northern and eastern parts of the basin; the Sprague River (a tributary to the Williamson) which drains part of the eastern side of the basin; the Lost River, which drains the southeastern part of the basin; and the Klamath River (fig. 1). The Lost River subbasin is actually a closed stream basin. Prior to development, the river flowed to internally drained Tule Lake, although it occasionally received flow from the Klamath River during floods. The Lost River is now diverted just below Olene into a channel across a low divide to the Klamath River. Generally, little water from the Lost River drainage above the diversion channel now flows to the Tule Lake subbasin. The largest lake in the basin is Upper Klamath Lake, which has a surface area between 100 and 140 $\mathrm{mi}^{2}$ (including non-drained fringe wetlands) depending on stage (Hubbard, 1970; Snyder and Morace, 1997). Principal tributaries to Upper Klamath Lake include the Williamson River, the Wood River (which originates at a series of large springs north of the lake), and several streams emanating from the Cascade Range.

The 250-mi (mile)-long Klamath River begins at the outlet of Upper Klamath Lake, which is controlled by a dam. For the first mile downstream of the lake, the river is known as the Link River. About $1 \mathrm{mi}$ below the dam, the river flows into a 20-mi-long narrow reservoir behind Keno Dam known as Lake Ewauna. The dam for another impoundment, John C. Boyle Reservoir, is about 10 mi below Keno Dam. Below John C. Boyle Dam, the river enters a narrow canyon and flows freely about $20 \mathrm{mi}$ to Copco Lake (a reservoir) and immediately below that, Iron Gate Reservoir. Iron Gate Dam, at about river mile 190, marks the downstream boundary of the upper Klamath Basin. There are no impoundments on the Klamath River below Iron Gate Dam.

The surface hydrology of the upper Klamath Basin has been extensively modified by drainage of lakes and wetlands for agriculture and routing of irrigation water. Prior to development, the Tule Lake and Lower Klamath Lake subbasins contained large lakes fringed by extensive wetlands. Under natural conditions, the Lost River flowed from the upper Lost River subbasin through the gap near Olene and then south to Tule Lake. The Lost River system received flow from the Klamath River system during periods of flood. Prior to development of the Bureau of Reclamation Klamath Project, the high stage of Tule Lake was about 4,060 $\mathrm{ft}$ (La Rue, 1922). At this stage, the lake would cover an area exceeding 96,000 acres. Historical accounts indicate that at high stage Tule Lake drained into the lava flows along the southern margin. In the early 1900s, the U.S. Reclamation Service (predecessor to the Bureau of Reclamation) experimented with augmenting this subsurface drainage in early attempts to drain the lake. La Rue (1922) argued that the fact that the water of Tule Lake was fresh, and not saline, was proof that the lake "in the past had an outlet." Subsurface drainage is also suggested by the hydraulic head gradient that slopes southward away from the Tule Lake subbasin toward the Pit River Basin. In 1912, a canal and dam were completed that allowed the diversion of water from the Lost River to the Klamath River, cutting off the supply of water to Tule Lake. Most of the Tule Lake Basin was drained and is now 


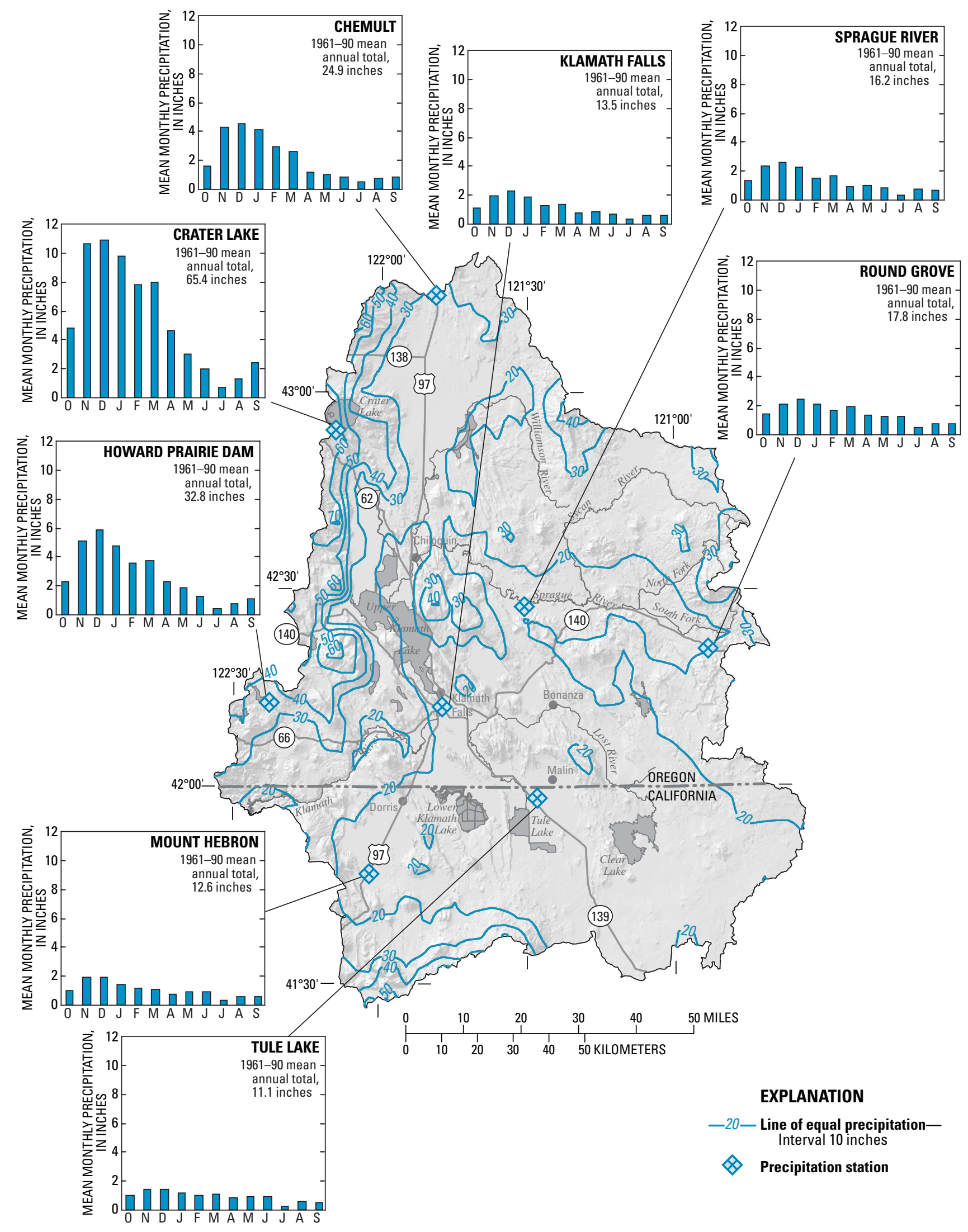

Figure 2. Distribution of precipitation in the upper Klamath Basin, Oregon and California, and mean monthly precipitation at selected precipitation measurement stations. (Data from Oregon State University PRISM Group, 2006; and Western Regional Climate Center, 2006.) 
under cultivation. The only remnant of the lake is the Tule Lake Sump in the southern and western parts of the basin that collect irrigation return flow. Since 1942, water from the sump has been pumped via tunnel through Sheepy Ridge into the Lower Klamath Lake subbasin. The Lower Klamath Lake subbasin once held a large lake-marsh complex that covered approximately 88,000 acres, about 58,000 acres of which were marginal wetlands with the remaining 30,000 acres open water (La Rue, 1922). Lower Klamath Lake was connected to the Klamath River through a channel known as the Klamath Strait, and probably through the expansive wetland that separated the lake from the river elsewhere. In the early 1900s, a railroad dike was constructed across the northwestern margin of the Lower Klamath Lake subbasin, cutting off flow between the lake and river except at the Klamath Strait. In 1917, the control structure at the Klamath Strait was closed, cutting off flow to the lake. As a result, Lower Klamath Lake is now largely drained, with much of the former lake bed and fringe wetlands under cultivation. Areas of open water remain in the Lower Klamath Lake Wildlife Refuge in the southern part of the subbasin.

Currently (2007), about 500,000 acres of agricultural land are irrigated in the upper Klamath Basin, roughly 190,000 of which are included in the Bureau of Reclamation Klamath Project (fig. 3) (Carlson and Todd, 2003; Natural Resources Conservation Service, 2004). This total does not include wildlife refuge areas within the Project.

The upper Klamath Basin is mostly forested (Loy and others, 2001). Forest trees in upland areas east of the Cascade Range are predominantly ponderosa pine, with areas of true fir and Douglas fir on Yamsay and Gearhart Mountains. Forests in the Cascade Range are composed primarily of mountain hemlock and red fir. Lower elevation uplands are dominated by lodgepole pine. Lowland forests consist largely of juniper and sagebrush with some juniper grasslands. Stream valleys and the broad, sediment-filled structural basins generally have extensive marshes, such as Sycan Marsh and Klamath Marsh, except at lower elevations, where the basins have been mostly converted to agricultural land (for example, the Wood River Valley, and the Lower Klamath Lake and Tule Lake subbasins).

The population of the upper Klamath Basin is approximately 70,000. Klamath County, most of which is in the upper Klamath Basin, had a population of 64,600 in 2003, most of which live in the Klamath Falls area (Oregon Blue Book, 2006). Few people live outside Klamath County in the Oregon part of the basin. The population in the California part of the upper Klamath Basin is difficult to estimate. Population in the block groups from the 2000 census that include the populated parts of Modoc and Siskiyou Counties in the basin is slightly more than 3,000. Some small settlements and ranches may not be included in these block groups.

Principal sectors of the economy in the upper Klamath Basin, in terms of output and employment, include forest products, agriculture, construction, retail, health care, and services (Weber and Sorte, 2003). In the agricultural sector, principal crops include (in approximate order, with largest acreages first) alfalfa hay, irrigated pasture, grains, and potatoes (Carlson and Todd, 2003; Siskiyou County, 2003). The proportions vary slightly between land inside and outside the Bureau of Reclamation Klamath Project, and between land in Oregon and California. Project lands in California tend to include more grains than alfalfa. Most agricultural land in the upper Klamath Basin (not including rangeland) is irrigated. A substantial part of the local economy, therefore, relies on irrigation water.

Irrigation water comes from a variety of sources in the upper Klamath Basin. Upstream of Upper Klamath Lake, in the Williamson, Sprague, and Wood River drainages, private (non-Project) irrigation water comes primarily from diversion of surface water from the main-stem streams or tributaries. A smaller amount of irrigation water is pumped from ground water, particularly in the Sprague River Valley and Klamath Marsh areas. In the Langell and Yonna Valleys of the upper Lost River subbasin, irrigation water comes from Clear Lake and Gerber Reservoirs. Irrigators use ground water and some surface water in Swan Lake Valley. Ground water is used for irrigation in areas not served by irrigation districts and to supplement surface-water supplies throughout the area.

South of Upper Klamath Lake, most irrigation water comes from the lake, which is the largest single source of irrigation water in the upper Klamath Basin. This area is the main part of the Bureau of Reclamation Klamath Project. Water is stored in and diverted from the lake to irrigate land south of Klamath Falls, including the Klamath Valley, Poe Valley (in the Lost River subbasin upstream of Olene Gap), and the Tule Lake subbasin. Irrigation return flow (water that originates in Upper Klamath Lake) that ends up in the Tule Lake Sump is pumped through Sheepy Ridge and used for irrigation and refuge use in the southern part of the Lower Klamath Lake subbasin. Water diverted from the Klamath River several miles downstream of the lake also is used for irrigation and refuges in the Lower Klamath Lake subbasin. Irrigation and refuge return flow in the Lower Klamath Lake subbasin is routed back up the Klamath Strait drain through a series of pumping stations to the Klamath River.

A certain amount of ground water is used for irrigation on land surrounding the Klamath Project upslope of the major canals. Principal areas of ground-water use surrounding the Project area include the southern end of the Klamath Hills, parts of the Klamath Valley, and the northern and eastern margins of the Tule Lake subbasin (fig. 1). Some ground water traditionally has been used for supplemental irrigation in the Project area. Increased water demand due to drought and requirements for a 100,000 acre-ft pilot water bank placed on Reclamation by the National Oceanic and Atmospheric Administration (NOAA) Fisheries 2002 biological opinion (National Marine Fisheries Service, 2002) have resulted in a marked increase in ground-water pumping in and around the Klamath Project since 2001. 


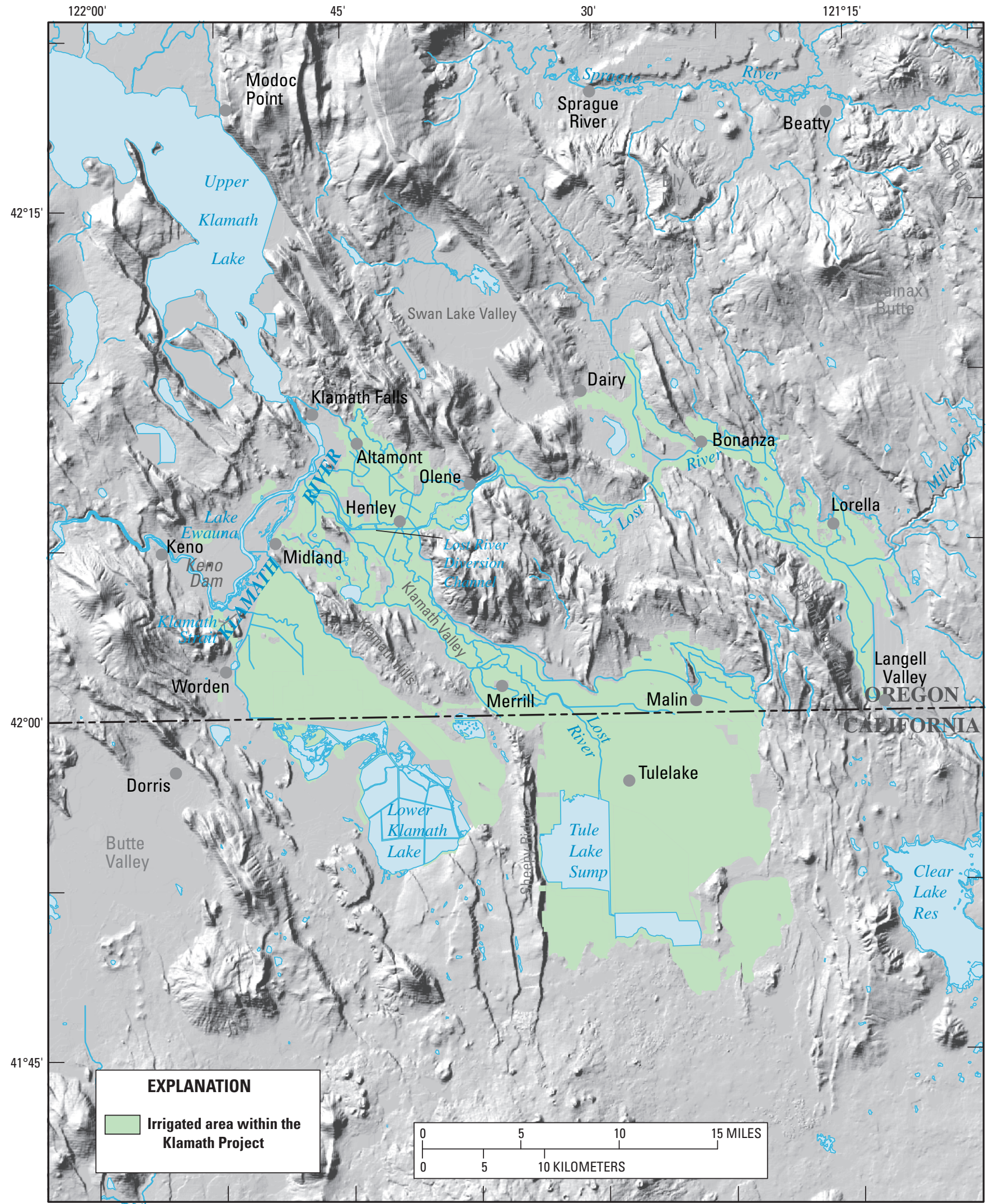

See table of contents for mapping sources

Figure 3. Irrigated areas in the Bureau of Reclamation Klamath Project, Oregon and California. 


\section{Purpose and Scope}

This report summarizes the present understanding of regional ground-water flow in the upper Klamath Basin resulting from the USGS-OWRD cooperative study. The report provides a description of the ground-water hydrology for resource managers, water users, and those with a general interest. It is also intended to provide sufficient quantitative information useful to hydrologists working in the basin, and to provide background for subsequent reports and investigations.

The report is regional in scope. Thus, data and analysis presented herein are intended to provide an understanding of the ground-water hydrology at a regional scale. Although the information and interpretations are useful for understanding the hydrologic setting of smaller areas, the ground-water hydrology of local areas is generally not discussed in detail.

The report covers many key aspects of the regional ground-water system. A summary of the geologic framework of the regional ground-water system is presented that is based on existing geologic mapping, field reconnaissance, radiometric age dates, and interpretation of lithologic data from more than 1,000 wells. A regional ground-water budget (including recharge and discharge), calculated from precipitation data, streamflow data, measured and estimated ground-water discharge to streams, and estimated evapotranspiration, also is provided. The distribution of hydraulic head, which controls ground-water flow directions, was estimated from water-level measurements in more than 1,000 wells, altitudes of gaining stream reaches, and altitudes of hundreds of springs mapped on USGS quadrangle maps. The response of the flow system to climate variations and pumping stresses was determined by using time-series waterlevel measurements from wells throughout the basin, with frequencies ranging from hours to months and periods ranging from years to decades, and from streamflow data.

\section{Geologic Framework}

\section{Geologic Controls on Ground-Water Flow}

The principal geologic factors that influence ground water are the porosity and permeability of the rock or sediment through which it flows. Porosity, in general terms, is the proportion of a rock or deposit that consists of open space. In a gravel deposit, this would be the proportion of the volume of the deposit represented by the space between the individual pebbles and cobbles. Permeability is a term used to describe the ease with which a fluid can move through a material such as rock or sedimentary deposits. Deposits with large interconnected open spaces, such as gravel, offer little resistance to ground-water flow and are, therefore, usually highly permeable. Rocks with few, very small, or poorly connected open spaces offer considerable resistance to ground-water flow and, therefore, have low permeability. The hydraulic characteristics of geologic materials vary between and within rock types. For example, in sedimentary deposits the permeability is a function of grain size and the range of grain sizes (the degree of sorting). Coarse, well-sorted gravel has much higher permeability than well-sorted sand. A wellsorted sand or gravel has a higher permeability than a deposit that is poorly sorted and has the open spaces between pebbles or sand grains filled with silt or clay. Clay-rich deposits generally have very low permeability. The permeability of lava flows also can vary markedly depending on the degree of fracturing. The highly fractured, rubbly zones at the tops and bottoms of lava flows and in interflow zones are often highly permeable, whereas the dense interior parts of lava flows can have very low permeability. Weathering and secondary mineralization, which often are a function of the age of the rock, can strongly influence permeability. Sedimentary deposits or lava flows in which the original open spaces have been filled with secondary minerals can have very low permeability.

Geologic properties that influence the movement of ground water within a flow system also can define the boundaries of the system. Geologic terranes consisting of predominantly low-permeability materials can form the boundaries of a regional flow system.

\section{General Geology}

The upper Klamath Basin has been a region of volcanic activity for at least 35 million yr (years) (Sherrod and Smith, 2000), resulting in complex assemblages of volcanic vents and lava flows, pyroclastic deposits, and volcanically derived sedimentary deposits. Volcanic and tectonic processes have created many of the present-day landforms in the basin. Glaciation and stream processes have subsequently modified the landscape in many places.

The upper Klamath Basin lies within two major geologic provinces, the Cascade Range and the Basin and Range Province (Orr and others, 1992). The processes that have operated in these provinces have overlapped and interacted in much of the upper Klamath Basin. The Cascade Range is a north-south trending zone of compositionally diverse volcanic eruptive centers and their deposits extending from northern California to southern British Columbia. The Cascade Range is subdivided between an older, highly eroded Western Cascades, and a younger, mostly constructional High Cascades. Prominent among the eruptive centers in the High Cascades of the Klamath Basin are large composite and shield volcanoes such as Mount Mazama (Crater Lake), Mount McLoughlin, and Medicine Lake Volcano. The Cascade Range has been impinged on its eastern side by the adjacent structurally dominated Basin and Range Province. The Basin and Range Province is a region of crustal extension characterized by subparallel, fault-bounded, down-dropped 
basins separated by fault-block ranges. Individual basins and intervening ranges are typically 10-20 mi across. The Basin and Range Province encompasses much of the interior of the Western United States, extending from central Oregon southward through Nevada and western Utah, into the southern parts of California, Arizona, and New Mexico. Although the Basin and Range Province is primarily structural, faulting has been accompanied by widespread volcanism.

The oldest rocks in the upper Klamath Basin study area are part of the Western Cascades subprovince and consist primarily of lava flows, andesitic mudflows, tuffaceous sedimentary rocks, and vent deposits. The Western Cascade rocks range in age from 20 to 33 million years (my) and are as much as 20,000 ft thick (Hammond, 1983; Vance, 1984). Rocks of the Western Cascades overlie pre-Tertiary rocks of the Klamath Mountains Province, just west of the study area. Western Cascades rocks have very low permeability because the tuffaceous materials are mostly devitrified (changed to clays and other minerals), and lava flows are weathered and contain abundant secondary minerals. Because of the low permeability, ground water does not easily move through the Western Cascades rocks, and the unit acts as a barrier to regional ground-water flow. The Western Cascades constitute part of the western boundary of the regional ground-water flow system. Western Cascade rocks dip toward the east and underlie the High Cascade deposits, and define the lower boundary of the regional flow system throughout that part of the study area.

The High Cascade subprovince ranges in age from late Miocene (7 my) to Recent; however, most rocks are Pliocene (5 my) to Recent in age (Mertzman, 2000). Deposits within the High Cascade subprovince in the study area mostly form constructional features and consist of volcanic vents and lava flows with relatively minor interbedded volcaniclastic and sedimentary deposits. An area of numerous late Miocene to Pliocene cinder cones extends from southwest of Butte Valley to northwest of Mt. Mazama (Crater Lake). Quaternary volcanic deposits are associated with a few volcanic centers concentrated in two general areas in the upper Klamath Basin: from Lake of the Woods north to Crater Lake and from Mt. Shasta (south of the study area) east to Medicine Lake Volcano. The High Cascades rocks are relatively thin in southern Oregon and northern California, typically measured in hundreds of feet thick, rather than thousands (Stan Mertzman, Franklin and Marshall College, written commun., 2003). High Cascade rocks unconformably overlie Western Cascade rocks and are very permeable, relative to the older rocks.

Basin and Range Province deposits in the study area range in age from middle Miocene (13 my) to Recent. The oldest rocks are middle to late Miocene in age, ranging from 13 to 8 my. These rocks are exposed just south of the study area in the Pit River Basin and are equivalent to the upper Cedarville Series of Russell (1928). In the study area, those rocks probably underlie the Pliocene age lavas south of Clear
Lake Reservoir. The older rocks in the Pit River Basin and bounding the eastern part of the study area are mostly silicic domes, flows, and pyroclastic deposits, which generally have low permeability (California Department of Water Resources, 1963) and typically are faulted and tilted.

Late Miocene to Pliocene volcanic rocks of the Basin and Range Province are the major water bearing rocks in the upper Klamath Basin study area. These units consist of volcanic vent deposits and flow rocks throughout the area east of Upper Klamath Lake and Lower Klamath Lake, and probably underlie most of the valley- and basin-fill deposits in the study area. Late Miocene to Pliocene rocks also form uplands along the eastern boundary of the study area, and form the plateau that extends from the Langell Valley south to the Pit River. The rocks are predominately basalt and basaltic andesite in composition, but silicic vents and lava flows occur locally, notably in the vicinity of Beatty, Oregon.

Tuff cones and tuff rings are the predominant volcanic vent form in the Sprague River subbasin between Chiloquin and Sprague River, Oregon. Tuff cones and rings form when rising magma comes in contact with water, resulting in explosive fragmentation of the volcanic material. The late Miocene to Pliocene rocks typically exhibit high to very high permeability. However, the permeability locally may be markedly reduced by secondary mineralization from hydrothermal alteration.

The volcanic rocks of the Basin and Range Province are interbedded with, and locally overlain by, late Miocene to Pliocene sedimentary rocks. The sedimentary rocks consist of tuffaceous sandstone, ashy diatomite, mudstone, siltstone, and some conglomerates. These units are exposed both in downdropped basins and in up-thrown mountain blocks, indicating that the deposits in part represent an earlier generation of sediment-filled basins have been subsequently faulted and uplifted. These sedimentary deposits are typically poor water producers, and often serve as confining layers for underlying volcanic aquifers.

The youngest stratigraphic unit in the upper Klamath Basin consists of late Pliocene to Recent sedimentary deposits. Those deposits include alluvium along modern flood plains, basin-fill deposits within active grabens, landslide deposits, and glacial drift and outwash. Very thick accumulations of silt, sand, clay, and diatomite underlie the westernmost basins, such as the Upper Klamath Lake, Lower Klamath Lake, Butte Valley, and Tule Lake subbasins. For example, up to $1,740 \mathrm{ft}$ of basin-fill sediment underlies the town of Tulelake, California. Sediment near the base of the deposit at Tulelake has been assigned an age of 3.3 my on the basis of radiometric ages of interbedded tephra, paleomagnetic data, and estimates of sedimentation rates (Adam and others, 1990). Gravity data suggest that the sediment-fill thickness may exceed 6,000 ft in the Lower Klamath Lake subbasin and may be in the range of 1,300 to 4,000 $\mathrm{ft}$ in the Upper Klamath Lake subbasin (Sammel and Peterson, 1976; Veen, 1981; Northwest Geophysical Associates Inc., 2002). 


\section{Hydrogeologic Units}

Hundreds of distinct and mappable geologic units have been identified by geologists in the upper Klamath Basin. Many of these geologic units have very similar hydrologic characteristics. For purposes of the description and analysis of regional ground-water flow, geologic units are typically combined into a smaller number of hydrogeologic units. Hydrogeologic units consist of groupings of geologic units that contain rock types of similar hydrologic characteristics and are distinct from other units. The geology of the upper Klamath Basin is herein generalized into eight hydrogeologic units (fig. 4 and table 1). Pre-Tertiary rocks are not exposed in outcrops or penetrated by wells in the study area and are not discussed.

Early to mid-Tertiary volcanics and sediments (Tovs), the oldest hydrogeologic unit in the study area, comprises Miocene and older lava and volcaniclastic rocks of the Western Cascade subprovince along the western margin of the study area, as well as older volcanic deposits beneath late Tertiary lavas along the eastern margin. The unit also includes older rocks exposed in the Pit River Basin southeast of the study area. The permeability of this unit is generally low due to weathering, hydrothermal alteration, and secondary mineralization. This unit is herein considered a boundary to the regional ground-water system of the upper Klamath Basin.

Late Tertiary volcaniclastic deposits (Tvpt) include palagonitized basaltic ash and lapilli deposits associated with eruptive centers. The hydrologic characteristics of this unit are not well known, but springs emerge from basal contact with unit Ts. This unit is most prominent in the Sprague River Valley.

Late Tertiary sedimentary rocks (Ts) consist predominately of fine-grained continental sedimentary deposits that include bedded diatomite, mudstone, siltstone, and sandstone. This unit has generally low permeability. These deposits occur throughout the central part of the upper Klamath Basin. They are exposed in uplands in interior parts of the basin and penetrated by wells in the river valleys. Lithologic logs of wells in the Sprague River Valley indicate that the thickness of these sedimentary deposits there locally exceeds $1,500 \mathrm{ft}$.

Late Tertiary volcanic rocks ( $\mathrm{Tv}$ ) consist predominately of basaltic and andesitic lava flows and vent deposits, but the unit includes local silicic domes and flows. This unit is locally affected by hydrothermal alteration and secondary mineralization. This is the most geographically extensive hydrogeologic unit, occurring throughout most of the upper Klamath Basin. The unit has moderate to high permeability and is by far the most widely developed aquifer unit in the study area.

Quaternary to late Tertiary sedimentary rocks (QTs) consist of medium- to coarse-grained unconsolidated to moderately indurated sedimentary deposits. The hydraulic characteristics of this unit are not well known, but lithologic descriptions on maps suggest that it is moderately permeable at some locations. This unit occurs locally in the western Wood River Valley, south of Klamath Falls, and in the uppermost Williamson River subbasin.

Quaternary volcanics (Qv) consist primarily of basaltic and andesitic lavas and vent deposits occurring in the Cascade Range and around Medicine Lake Volcano. These materials are generally highly permeable.

Quaternary volcaniclastic deposits (Qvp) consist primarily of pyroclastic flows and air-fall material (pumice ash and lapilli) deposited during the climactic eruption of Mt. Mazama that formed the caldera encompassing Crater Lake. This unit is most extensive in the Cascade Range around Crater Lake and in the upper Williamson River subbasin. As mapped (fig. 4), the unit also includes debris avalanche deposits in the Shasta River Valley outside of the study area. Minor Quaternary pyroclastic deposits occur on Medicine Lake Volcano and in Butte Valley. Air-fall deposits are highly permeable.

Quaternary sediments (Qs) include the alluvial deposits in principal stream valleys, glacial deposits in the Cascade Range, and basin-filling sediments in the major lake basins. The basin-filling deposits are generally fine grained and have low permeability. Coarse facies occur at some locations within the basin-filling deposits.

\section{EXPLANATION FOR FIGURE 4}

\section{Hydrogeologic unit present at land surface}

\begin{tabular}{|c|c|}
\hline Qs & Quaternary sedimentary deposits \\
\hline Qvp & Quaternary volcaniclastic deposits \\
\hline Ov & Quaternary volcanic rocks \\
\hline OTs & Quaternary to late Tertiary sedimentary rocks \\
\hline Ts & Late Tertiary sedimentary rocks \\
\hline Tvpt & Late Tertiary volcaniclastic rocks \\
\hline Tv & Late Tertiary volcanic rocks \\
\hline Tovs & Older Tertiary volcanic and sedimentary rocks \\
\hline pT & Pre-Tertiary rocks \\
\hline$\overline{-\ldots . .}$ & $\begin{array}{l}\text { Geologic fault, dashed where inferred, } \\
\text { dotted where concealed }\end{array}$ \\
\hline & $\begin{array}{l}\text { logy generalized from: } \\
\text { and Aune, 1958; } \\
\text { Iker, 1963; } \\
\text { ith and others, 1982; } \\
\text { gner and Saucedo, 1987; } \\
\text { errod, 1991; } \\
\text { cLeod and Sherrod, 1992; } \\
\text { errod and Pickthorn, 1992, and } \\
\text { errod and Smith, 2000. }\end{array}$ \\
\hline
\end{tabular}




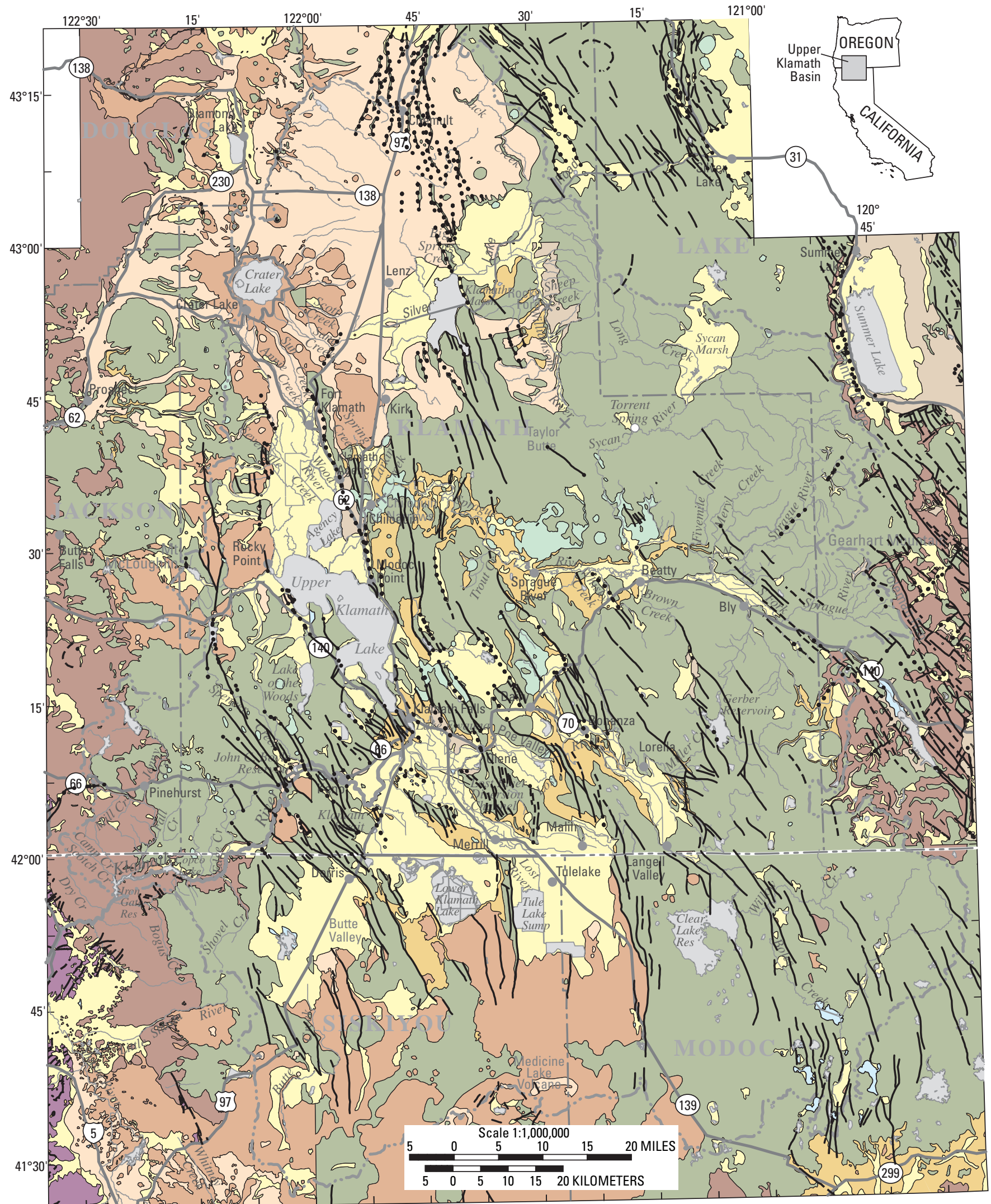

See table of contents for mapping sources

Figure 4. Hydrogeologic units of the upper Klamath Basin, Oregon and California. 
Table 1. Generalized hydrogeologic units in the upper Klamath Basin, Oregon and California.

\begin{tabular}{|c|c|c|}
\hline Hydrogeologic unit & Map symbol & Lithologic and hydrologic characteristics \\
\hline $\begin{array}{l}\text { Quaternary } \\
\text { volcaniclastic } \\
\text { deposits }\end{array}$ & Qvp & $\begin{array}{l}\text { Pyroclastic flows and air fall material (pumice, ash, and lapilli) deposited during the climactic eruption } \\
\text { of Mt. Mazama that formed Crater Lake, and debris avalanche deposits of the Shasta River Valley. Air } \\
\text { fall deposits are highly permeable. Pyroclastic flows and debris deposits may have low permeability. }\end{array}$ \\
\hline $\begin{array}{l}\text { Quaternary to } \\
\text { late Tertiary } \\
\text { sedimentary rocks }\end{array}$ & QTs & $\begin{array}{l}\text { Fine- to coarse-grained unconsolidated to moderately indurated sedimentary deposits. The hydraulic } \\
\text { characteristics of this unit are not well known but lithologic descriptions on maps suggest it may be } \\
\text { moderately permeable at some locations. This unit has very limited distribution. }\end{array}$ \\
\hline $\begin{array}{l}\text { Late Tertiary } \\
\text { sedimentary rocks }\end{array}$ & Ts & $\begin{array}{l}\text { Predominately fine-grained continental sedimentary deposits including bedded diatomite, mudstone, } \\
\text { siltstone, and sandstone. This unit has generally low permeability but contains permeable strata at } \\
\text { some locations. }\end{array}$ \\
\hline $\begin{array}{l}\text { Late Tertiary } \\
\text { volcanic rocks }\end{array}$ & $\mathrm{Tv}$ & $\begin{array}{l}\text { Predominantly basaltic and andesitic lava flows and vent deposits with lesser amounts of silicic domes } \\
\text { and flows. This unit has moderate to high permeability and is by far the most widely developed aquifer } \\
\text { unit in the study area. Permeability is locally diminished by hydrothermal alteration and secondary } \\
\text { mineralization. }\end{array}$ \\
\hline $\begin{array}{l}\text { Older Tertiary } \\
\text { volcanic and } \\
\text { sedimentary rocks }\end{array}$ & Tovs & $\begin{array}{l}\text { Miocene and older volcanic and volcaniclastic deposits. The permeability of this unit is generally low } \\
\text { due to weathering, hydrothermal alteration, and secondary mineralization. This unit is generally } \\
\text { considered a boundary to the regional ground-water system of the upper Klamath Basin. }\end{array}$ \\
\hline
\end{tabular}

\section{Effects of Geologic Structure}

Geologic structures, principally faults and fault zones, can influence ground-water flow. Fault zones can act as either barriers to or conduits for ground-water flow, depending on the material in and between the individual fault planes. Faults most commonly affect ground-water flow by juxtaposing rocks of contrasting permeability or by affecting the patterns of deposition. Structural basins caused by normal faulting, called grabens, can act as depositional centers for large thicknesses of sediment or lava that may influence regional ground-water flow. Faults do not always influence ground-water flow; there are regions in the upper Klamath Basin where ground-water flow appears unaffected by the presence of faults.

The area of the upper Klamath Basin lying east of the Cascade Range is a composite graben that forms the westernmost structural trough of the Basin and Range physiographic province (Sherrod and Pickthorn, 1992). The predominant fault direction is north-northwest, as shown in figure 4. According to Sherrod and Pickthorn (1992), offset across the faults range from less than $300 \mathrm{ft}$ in the central and eastern parts of the graben to about $6,000 \mathrm{ft}$ on faults southwest of Klamath Falls.

\section{Hydraulic Characteristics of Regional Hydrogeologic Units}

Geologic materials possess certain hydraulic characteristics that control the movement and storage of ground water. This section describes the basic parameters used to characterize aquifer hydraulic properties and presents estimates or ranges of values of those terms for some of the major geologic units in the upper Klamath Basin. A more thorough discussion of the terms used to describe the hydraulic characteristics of aquifers and aquifer materials can be found in any basic ground-water hydrology text such as Freeze and Cherry (1979), Fetter (1980), or Heath (1983).

The term "permeability" was introduced previously as a measure of the ease with which fluid can move through a particular rock type or deposit. Permeability is an intrinsic property of the rock type, and is independent of the fluid properties. In ground-water studies, the term "hydraulic conductivity" is used more commonly than "permeability" in quantitative discussions. The hydraulic conductivity includes both the properties of the rock (the intrinsic permeability) and the properties of the water, such as viscosity and density. 
Hydraulic conductivity is generally defined as the volume of water per unit time that will pass through a unit area of an aquifer material in response to a unit hydraulic head gradient. Hydraulic conductivity has the units of volume per unit time (such as cubic feet per day) per unit area (such as square feet), which simplifies by division to length per unit time (such as feet per day). Hydraulic conductivity values for aquifer materials commonly span several orders of magnitude from less than $0.1 \mathrm{ft} / \mathrm{d}$ for fine sand and silt to over $1,000 \mathrm{ft} / \mathrm{d}$ for well-sorted sand and gravel.

When discussing aquifers instead of rock types, the hydraulic conductivity is multiplied by the aquifer thickness resulting in a parameter known as "transmissivity." Transmissivity is defined as the volume of water per unit time that will flow through a unit width of an aquifer perpendicular to the flow direction in response to a unit hydraulic head gradient. Transmissivity has units of volume per unit time (such as cubic feet per day) per unit aquifer width (such as feet), which simplifies to length squared per unit time (such as feet squared per day $\left[\mathrm{ft}^{2} / \mathrm{d}\right]$ ).

Storage characteristics of an aquifer are described by a parameter known as the "storage coefficient." The storage coefficient is defined as the volume of water an aquifer releases from, or takes into, storage per unit area of aquifer per unit change in head. The volume of water has units of length cubed (such as cubic feet), the area has units of length squared (such as square feet), and the head change has units of length (such as feet). Thus, the storage coefficient is dimensionless. Storage coefficients typically span several orders of magnitude from $10^{-4}$ for aquifers with overlying confining units, to 0.1 for unconfined aquifers. Storage coefficients commonly fall between these two end members because aquifers often have varying degrees of confinement. Note that characterizing an aquifer as "confined" does not imply that it is not hydraulically connected to other aquifers or to surface water. The terms "confined" and "unconfined" describe the physics of the aquifer response to pumping at a particular location.

The hydraulic characteristics of subsurface materials are typically determined by conducting aquifer tests. An aquifer test consists of pumping a well at a constant rate and measuring the change in water level (the drawdown) with time in the pumping well and nearby non-pumping wells. The data collected allow generation of a curve showing the drawdown as a function of time. Similar data are collected after the pumping is stopped, allowing generation of a curve showing the water-level recovery as a function of time. Analysis of the drawdown and recovery curves in the pumped well and observation wells provides estimates of the transmissivity and storage coefficient of the aquifer. Aquifer characteristics also can be estimated from certain well-yield tests called "specific-capacity tests," sometimes conducted by drillers. Data from specific capacity tests that include a pumping rate, test duration, drawdown at the end of the test, and the well diameter can be used to estimate aquifer transmissivity.

\section{Aquifer Tests}

The results of 32 aquifer tests conducted in the upper Klamath Basin are summarized in table 2. The tests were conducted by the OWRD, the California Department of Water Resources (CDWR), private consultants, and the USGS. Pumping periods for the tests ranged from $12 \mathrm{hr}$ (hours) to 169 days, with most lasting 24 to $72 \mathrm{hr}$. All tests were conducted on wells with large yields ranging from about 1,000 to $10,000 \mathrm{gal} / \mathrm{min}$. Most tests are of wells that produce from Tertiary volcanic deposits (unit Tv on fig. 4) because it is the most productive and widespread water bearing unit. A smaller number of tests were of wells producing from Tertiary sedimentary deposits (unit Ts on fig. 4) or a mixture of Ts and Tv. It should be noted that the Tertiary sediments are very fine grained over most of the basin, and that wells producing large yields from that unit occur only in specific locations.

Data and details of the analyses for most of the tests are available from sources listed in table 2. Reanalysis of the aquifer tests listed in table 2 was beyond the scope of this study. For the most part, the results presented are directly from the source documents, except that values have been rounded to two significant figures. In some cases, as noted in table 2, results from certain observation wells or certain analyses that were considered problematic were not included. For example, anomalous results from observation wells that were open to different water-bearing zones or constructed differently from the pumped well were excluded. Results from pumped wells were excluded where well loss (excessive drawdown due to well inefficiency) appeared to affect the results.

Most aquifer tests show evidence of boundaries, complicated aquifer geometry, or possible double-porosity conditions where flow occurs in fractures and in the blocks between fractures. Many tests in Butte Valley and the Tule Lake, Lower Klamath Lake, Sprague River, and upper Lost River subbasins showed inflections in drawdown curves, suggesting the presence of no-flow boundaries. These no-flow boundaries were in some cases associated with faults. Such boundaries indicate that the Tertiary volcanic aquifer system is, at least locally, somewhat compartmentalized, with some resistance to flow between individual subregions. Some tests showed evidence of recharge boundaries. Recharge boundaries usually indicate that the cone of depression has expanded to an extent where it has intersected a source of recharge, for example a stream or canal. Given the stratigraphy of the areas tested, the pumping more likely was inducing flow from the overlying low-permeability sediments. Tests that showed evidence of recharge boundaries or leaking confining layers occurred in the Lower Klamath Lake and Lost River subbasins. Inflections in drawdown curves can also be caused by double porosity conditions (Moench, 1984; Weeks, 2005). 


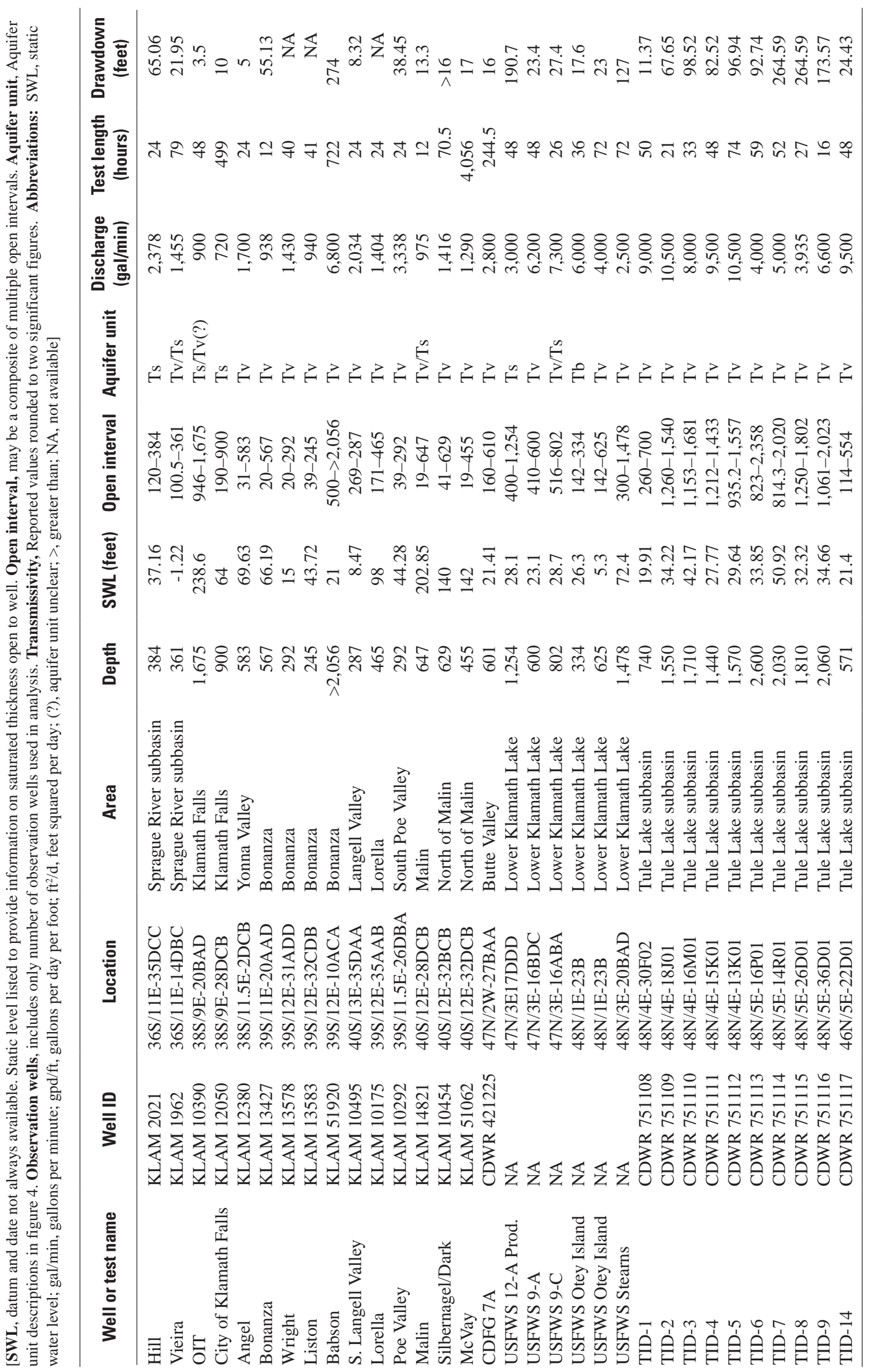




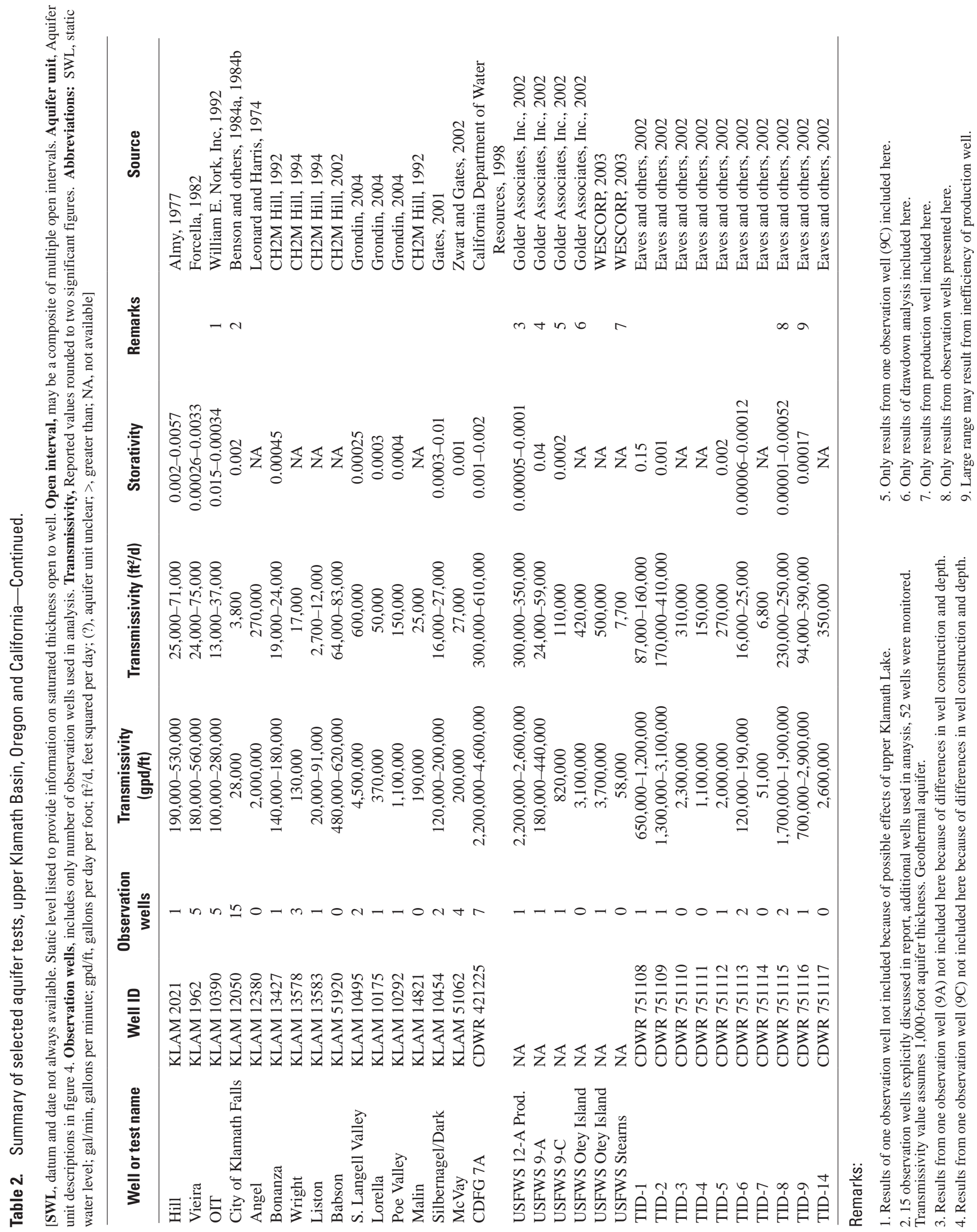


Aquifer tests show that the transmissivity of the Tertiary volcanics (predominantly basaltic lavas) varies widely, from 2,700 to $610,000 \mathrm{ft}^{2} / \mathrm{d}$, with most (the middle 50 percent) ranging from 24,000 to $270,000 \mathrm{ft}^{2} / \mathrm{d}$. The average transmissivity is about $170,000 \mathrm{ft}^{2} / \mathrm{d}$ and the median is about $90,000 \mathrm{ft}^{2} / \mathrm{d}$. Reported storage coefficients from aquifer tests in the Tertiary volcanics range from 0.00001 to 0.15 . The 0.15 figure is anomalous and likely due to a partially penetrating observation well and leakage from the confining layer. The middle 50 percent of the calculated storage coefficients in the Tertiary volcanics range from 0.00025 to 0.001 . The average value is 0.0012 and the median is about 0.0005 .

Although the number of aquifer tests in Tertiary sediments (or mixtures of the sediments and Tertiary lavas) is small ( $n=6$, not including the geothermal aquifer test), they provided information on the hydraulic characteristics of the coarse-grained facies of unit Ts. Transmissivity values range from 13,000 to $350,000 \mathrm{ft}^{2} / \mathrm{d}$, with most in the 25,000 to $75,000 \mathrm{ft}^{2} / \mathrm{d}$ range. The average value is about $100,000 \mathrm{ft}^{2} / \mathrm{d}$ and the median is $54,000 \mathrm{ft}^{2} / \mathrm{d}$. Storage coefficients range from 0.0005 to 0.015 with most ranging from about 0.0002 to 0.003 . Note that most Tertiary sedimentary rock in the basin consists of fine-grained lake deposits and has much lower transmissivity than determined from the tests discussed here.

In the early 1980s, the USGS conducted an aquifer test of the geothermal aquifer in Klamath Falls in collaboration with the Lawrence Berkeley Laboratory and the City of Klamath Falls (Benson and others, 1984a, b). The test consisted of four phases: a 1-week pre-test phase during which background water levels were monitored; a 21-day pumping phase during which a geothermal well (38S/09E-28DCB, KLAM 12050; table 2) was pumped at about $720 \mathrm{gal} / \mathrm{min}$ and the water discharged to an irrigation canal; a 30 day injection phase during which pumping continued (at about 660-695 gal/min) and the water injected into a second well (38S/09E-28DDD, KLAM 11940); and a 1-week recovery phase. Benson and others (1984a) analyzed the data from the test and calculated a permeability-thickness value (analagous to a transmissivity) of about $1.4 \times 10^{6}$ millidarcy-feet. This converts to a transmissivity of about $3,800 \mathrm{ft}^{2} / \mathrm{d}$. Analysis of the test indicated a storage coefficient of about 0.002 .

Results of the geothermal aquifer test are generally consistent with the other aquifer tests in table 2. The transmissivity value is at the lower end of the range of other tests, but this is not unexpected as the aquifer system pumped consists of interlayered lava and fine-grained sedimentary rock (unit Ts). A notable finding of this test is the apparent lack of boundaries encountered in an area crossed by several major basin-bounding faults. This is not, however, inconsistent with other hydrologic data that suggest ground water moves freely across similar faults at many locations.

\section{Well-Yield Tests}

Another source of information on subsurface hydraulic characteristics are the well-yield tests conducted by drillers and reported on the well logs submitted on completion of all new wells. Well-yield tests typically consist of a single drawdown measurement taken after a well has been pumped at a specified rate for a specified length of time, typically $1 \mathrm{hr}$. Well-yield tests allow determination of a well's specific capacity, which can be used to estimate transmissivity as described previously. Specific capacity is only a semiquantitative measure of well performance in that it can vary with pumping rate. Specific-capacity values can be used to calculate only rough estimates of the aquifer transmissivity and cannot be used to quantitatively derive aquifer storage characteristics. Although transmissivity values calculated from specific capacity tests are only approximate, they can be used to evaluate the relative differences in hydraulic characteristics between different geographic areas and different hydrogeologic units if data are available from a sufficient number of wells.

Specific-capacity data were analyzed from wells that were field inventoried for this study. Of the over 1,000 wells inventoried, only about 288 had sufficient information for analysis on their State water well reports. Transmissivity values were estimated from specific-capacity data using the Theis nonequilibrium equation (Theis, 1935). The wells analyzed were sorted by hydrogeologic units for comparison. Most wells analyzed produced from one of three units: Quaternary sedimentary deposits $(\mathrm{Qs})(\mathrm{n}=41)$, Tertiary sedimentary rocks $(\mathrm{Ts})(\mathrm{n}=48)$, and late Tertiary volcanic deposits $(\mathrm{Tv})(\mathrm{n}=173)$. Other units had too few tests for statistically meaningful comparisons. The cumulative frequencies of transmissivity estimates for the three major units are shown in figure 5. Wells producing from Quaternary sedimentary deposits and Tertiary sedimentary deposits have similar transmissivity distributions, with the former having slightly larger values. The median transmissivity for both units is about $200 \mathrm{ft}^{2} / \mathrm{d}$. The frequency distribution of transmissivities for the late Tertiary volcanic deposits is distinct from the other units, with values generally larger by more than an order of magnitude (fig. 5). The median transmissivity of Tertiary volcanic deposits is about $5,800 \mathrm{ft}^{2} / \mathrm{d}$.

The median transmissivity for late Tertiary volcanic deposits determined from specific-capacity tests $\left(6,300 \mathrm{ft}^{2} / \mathrm{d}\right)$ is lower than that calculated from aquifer tests (about $\left.90,000 \mathrm{ft}^{2} / \mathrm{d}\right)$. This is not unexpected for the following reasons: First, transmissivity values determined from single-well tests can be biased downward by excess drawdown in the pumped well due to well inefficiency (see Driscoll, 1986, p. 244). 


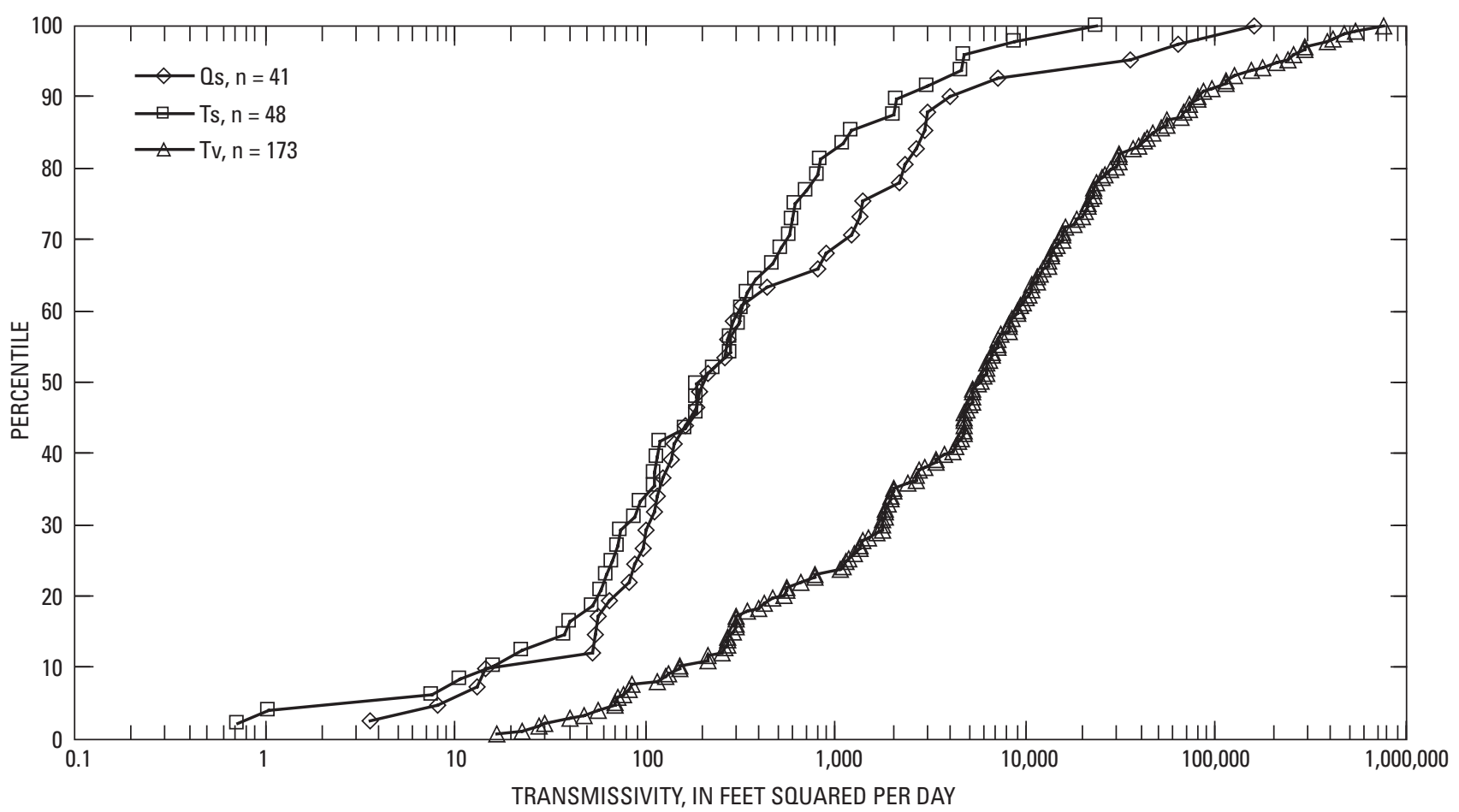

Figure 5. Cumulative distribution of transmissivity values estimated from specific-capacity tests for wells producing from Quaternary sediment, Tertiary sedimentary rock, and Tertiary volcanic rock in the upper Klamath Basin, Oregon and California.

Aquifer tests with observation wells are not affected by this phenomenon. Second, the large number of specific-capacity tests (173) represent a more or less random sampling of wells (and varying characteristics) in the unit. Aquifer tests, in contrast, are not random but tend to be conducted most commonly on high yielding wells for specific purposes. Regardless, transmissivity values calculated from both aquifer tests and specific-capacity tests are useful for understanding the hydraulic characteristics of hydrogeologic units and the differences between units.

\section{Ground-Water Hydrology}

Ground water moves from areas where it enters the ground, known as "recharge areas," to areas where it leaves the ground, known as "discharge areas." On a regional scale, recharge areas are typically high-elevation regions with large amounts of precipitation compared to surrounding areas. Ground water moves from recharge areas toward low-elevation areas in response to gravity. In low-elevation areas, ground water typically discharges to streams, lakes, or wetlands and then is returned to the atmosphere through evapotranspiration or leaves the basin as streamflow. Ground water can be removed anywhere along its flow path by wells.
Ground water moves in response to differences in hydraulic head, from areas of high head to areas of low head. In unconfined aquifers-those without overlying lowpermeability strata-hydraulic head can be thought of as the elevation of the water table. In confined aquifers, hydraulic head can be thought of as the elevation of the aquifer plus the pressure of the confined ground water. Maps of hydraulic head are useful for identifying recharge and discharge areas, and for indicating the direction of ground-water flow. Although the regional scale movement of ground water largely follows topography, the actual flow paths that the ground water follows and the rate of ground-water movement is controlled by the permeability of the geologic materials through which it flows. The rate of ground-water movement is proportional to the hydraulic head gradient and the permeability of the geologic materials.

Ground-water systems are dynamic, with rates of recharge and discharge and hydraulic head varying in response to external stresses. The largest external influence on ground-water systems is climate. Drought cycles cause large fluctuations in recharge, ground-water levels, and discharge to springs and streams. Human-caused stresses, such as pumping and artifical recharge from canal leakage and deep percolation of irrigation water, also affect the ground-water system. 


\section{Hydrologic Budget}

The hydrologic budget is the accounting of water moving into and out of a hydrologic system such as the upper Klamath Basin. A general hydrologic-budget equation is:

$\mathrm{PRECIP}+\mathrm{SW}_{\text {in }}+\mathrm{GW}_{\text {in }}=\mathrm{ET}+\mathrm{SW}_{\text {out }}+\mathrm{GW}_{\text {out }}+\Delta \mathrm{S},(1)$

Where

PRECIP is precipitation,

$\mathrm{SW}_{\text {in }}$ is the inflow of surface water,

$\mathrm{GW}_{\text {in }}$ is the subsurface inflow of ground water,

ET is total evapotranspiration,

$\mathrm{SW}_{\text {out }}$ is the out flow of surface water,

$\mathrm{GW}_{\text {out }}$ is the subsurface outflow of ground water, and

$\Delta \mathrm{S}$ is the change in water stored in the surface- and ground-water systems.

These individual terms may have multiple components. For example, ET includes the evapotranspiration from forests, wetlands, and agricultural crops. In the upper Klamath Basin, the largest terms are PRECIP, ET, and $\mathrm{SW}_{\text {out }}$. There is no evidence of subsurface ground-water flow into the basin $\left(\mathrm{GW}_{\text {in }}\right)$. Ground-water flow out $\left(\mathrm{GW}_{\text {out }}\right)$ toward the south is probable, but the amount is likely to be miniscule compared to other terms in the equation. The storage term $(\Delta S)$ includes both surface storage in reservoirs and subsurface storage of ground water in aquifers. When dealing with long-term, multiyear averages, changes in surface water storage are commonly negligible.

Long-term changes in ground-water storage are manifest as year-to-year changes in the water-table elevation. Longterm observation well data indicate that a slight, climaterelated decline has taken place in water levels in wells in the Klamath Basin since the 1950s. The magnitude of the decline varies spatially, but ranges from zero to about $10 \mathrm{ft}$ over 50 years. Larger declines have been measured near pumping centers, but are generally geographically restricted. The amount of water represented by the annual change in groundwater storage is small compared to the overall hydrologic budget. For example, assuming the change in storage occurred in the shallow, unconfined parts of the system and using a storage coefficient of 0.05 (a reasonable number for an unconfined volcanic aquifer), a decline of $5 \mathrm{ft}$ in 50 years averaged over the entire 8,000 $\mathrm{mi}^{2}$ upper Klamath Basin equates to an annual change in storage of about 26,000 acre-ft.

Some components of a hydrologic budget, such as streamflow, can be measured directly. Other components, such as evapotranspiration, are impractical or impossible to measure directly at useful scales and must be estimated or inferred from other measurements. This section presents a very general discussion of the hydrologic budget of the entire upper
Klamath Basin (summarized in table 3 ) to provide a context for a more detailed discussion of the hydrologic budget of the ground-water system. All figures presented in this section have associated uncertainty.

Data from the Oregon Climate Center PRISM Group (http://www.ocs.oregonstate.edu/prism/index.phtml, accessed September 20, 2006) indicates that precipitation in the upper Klamath Basin averages about 10 million acre-ft/yr (19712000 average). Of that amount, only about 1.5 million acre$\mathrm{ft} / \mathrm{yr}$ flows out of the basin past Iron Gate Dam (1961-2000 average; 1971-2000 average is 1.6 million acre-ft/yr). Most of the remaining 8.5 million acre-ft/yr returns to the atmosphere through evapotranspiration at the location where the precipitation falls. Some of the 8.5 million acre-ft/yr, however, returns to the atmosphere elsewhere in the basin after it has moved through the hydrologic system. An example of the latter case would be water diverted from streams or pumped from ground water that returns to the atmosphere through evapotranspiration from irrigated fields (this type of loss is often termed "consumptive use"). A small amount of water is exported from the basin. La Marche (2001) estimated water exports to the Rogue River Basin to average 0.027 million acre-ft/yr between 1960 and 1996

Burt and Freeman (2003) estimated that evapotranspiration from agricultural fields in the Klamath Project in 1999 and 2000 averaged 0.48 million acre-ft/yr (the 2001 estimates are not included here because of the cut off of irrigation water that year). Estimates by Cooper (2004) suggest that average annual agricultural consumptive use in the principal agricultural areas outside of the Klamath Project in Oregon (including the Williamson, Sprague, and Wood River subbasins) totals about 0.2 million acre-ft/yr. Consumptive use by ground-water irrigated agriculture outside of the Klamath Project in California (including areas in the Tule Lake and Butte Valley subbasins) is estimated to be about 0.072 million acre-ft/yr on the basis of data from the CDWR 2000 land use survey. Areas irrigated with surface water in California outside of the Project are small in comparison to ground-water irrigated areas and are not included in this total. There is also significant evapotranspiration from wetlands and open water in the upper Klamath Basin. Hubbard (1970) estimated that evapotranspiration from open water and the fringe wetlands of Upper Klamath Lake averaged 0.29 million acre-ft/yr from 1965 to 1967. Risley and Gannett (2006) estimated that evapotranspiration from the Tule Lake and Lower Klamath Lake refuges totaled about 0.22 million acre$\mathrm{ft} / \mathrm{yr}$ from 2003 to 2005. Average evapotranspiration in the Klamath Marsh area was estimated to be about 0.17 million acre-ft/yr using the method of Priestly and Taylor (1972) (Tim Mayer, U.S. Fish and Wildlife Service, written commun., 2005). Burt and Freeman (2003) estimated evapotranspiration from other surfaces in the Project area, including open water outside of refuges, urban areas, and undeveloped land to average about 0.082 million acre-ft/yr in 1999 and 2000. 
The source documents listed above all discuss uncertainty of the evapotranspiration estimates in general terms. Bert and Freeman (2003), however, provide a quantitative uncertainty assessment, and assign confidence intervals of plus or minus 14 to 20 percent for the estimates discussed here. Although the above list of evapotranspiration losses, which totals 1.5 million acre-ft/yr, is not exhaustive, it includes the bulk of consumptive uses in the nonupland parts of the basin. When this number is added to the streamflow out of the basin, about 7 million acre-ft/yr of precipitation (about 70 percent of the total precipitation) still leaves the basin through other avenues, principally as evapotranspiration to the atmosphere in upland areas.

A substantial proportion of the roughly 3 million acre-ft/yr that leaves the basin through streamflow or evapotranspiration in nonupland areas moves through the regional ground-water system. Equation 1 describes flow into and out of the entire upper Klamath Basin. Most flow into and out of the regional ground-water system occurs entirely within the basin. The hydrologic budget of the regional ground-water system can be described by the equation:

$$
\mathrm{RECH}+\mathrm{GW}_{\mathrm{in}}=\mathrm{GW}_{\text {dis }}+\mathrm{GW}_{\text {out }}+\Delta \mathrm{S} \text {, }
$$

where

RECH is ground-water recharge, and

$\mathrm{GW}_{\text {dis }}$ is ground-water discharge.

The largest terms in equation 2 are $\mathrm{RECH}$ and $\mathrm{GW}_{\text {dis }}$. Recharge (RECH) includes infiltration of precipitation, leakage from streams and canals, and deep percolation of irrigation water. Ground-water discharge $\left(\mathrm{GW}_{\text {dis }}\right)$ includes natural discharge of ground water to springs and streams, water consumed by plants with their roots extending to the water table, and by pumping of wells. A schematic depiction of a ground-water flow system is shown in figure 6 .

Table 3. Estimates of major hydrologic budget elements of the upper Klamath Basin, Oregon and California.

[ET, evapotranspiration; values in million acre feet per year; PRISM, Parameter-elevation Regressions on Independent Slopes Model (Oregon State University, PRISM Group, 2006); CDWR, California Department of Water Resources; USFWS, U.S. Fish and Wildlife Service; USGS, U.S. Geological Survey]

\begin{tabular}{|c|c|c|}
\hline Budget element & Value & Source and remarks \\
\hline $\begin{array}{l}\text { Precipitation } \\
\text { Subsurface inflow }\end{array}$ & $\begin{array}{l}10 \\
\text { unknown }\end{array}$ & $\begin{array}{l}\text { 1971-2000 average from PRISM } \\
\text { Assumed to be negligible }\end{array}$ \\
\hline Total inflow & 10 & \\
\hline
\end{tabular}

\begin{tabular}{|c|c|c|}
\hline \multicolumn{3}{|c|}{ Outflow } \\
\hline Subsurface outflow & unknown & Assumed to be negligible \\
\hline Surface outflow at Iron Gate Dam & 1.5 & 1961-2004 annual average (USGS gage data) \\
\hline \multicolumn{3}{|l|}{ ET from agricultural lands } \\
\hline Bureau of Reclamation Klamath & .48 & 1999 and 2000 average (Burt and Freeman, 2003) \\
\hline \multicolumn{3}{|l|}{ ET from major wetlands } \\
\hline Tule Lake and Klamath Refuge (not including open water) & .22 & 2003-05 average (Risley and Gannett, 2006) \\
\hline Upper Klamath Lake fringe wetlands & .29 & 1965-67 average (Hubbard, 1970) \\
\hline Klamath Marsh & .17 & $\begin{array}{l}\text { Estimated using the method of Priestly and Taylor (1972) (Tim } \\
\text { Mayer, U.S. Fish and Wildlife Service, written commun., } \\
\text { 2005) }\end{array}$ \\
\hline $\begin{array}{l}\text { Estimated ET from nonagricultural and upland areas outside } \\
\text { the Project }\end{array}$ & 7.0 & Total inflow minus outflow subtotal \\
\hline Total outflow & 10 & \\
\hline
\end{tabular}




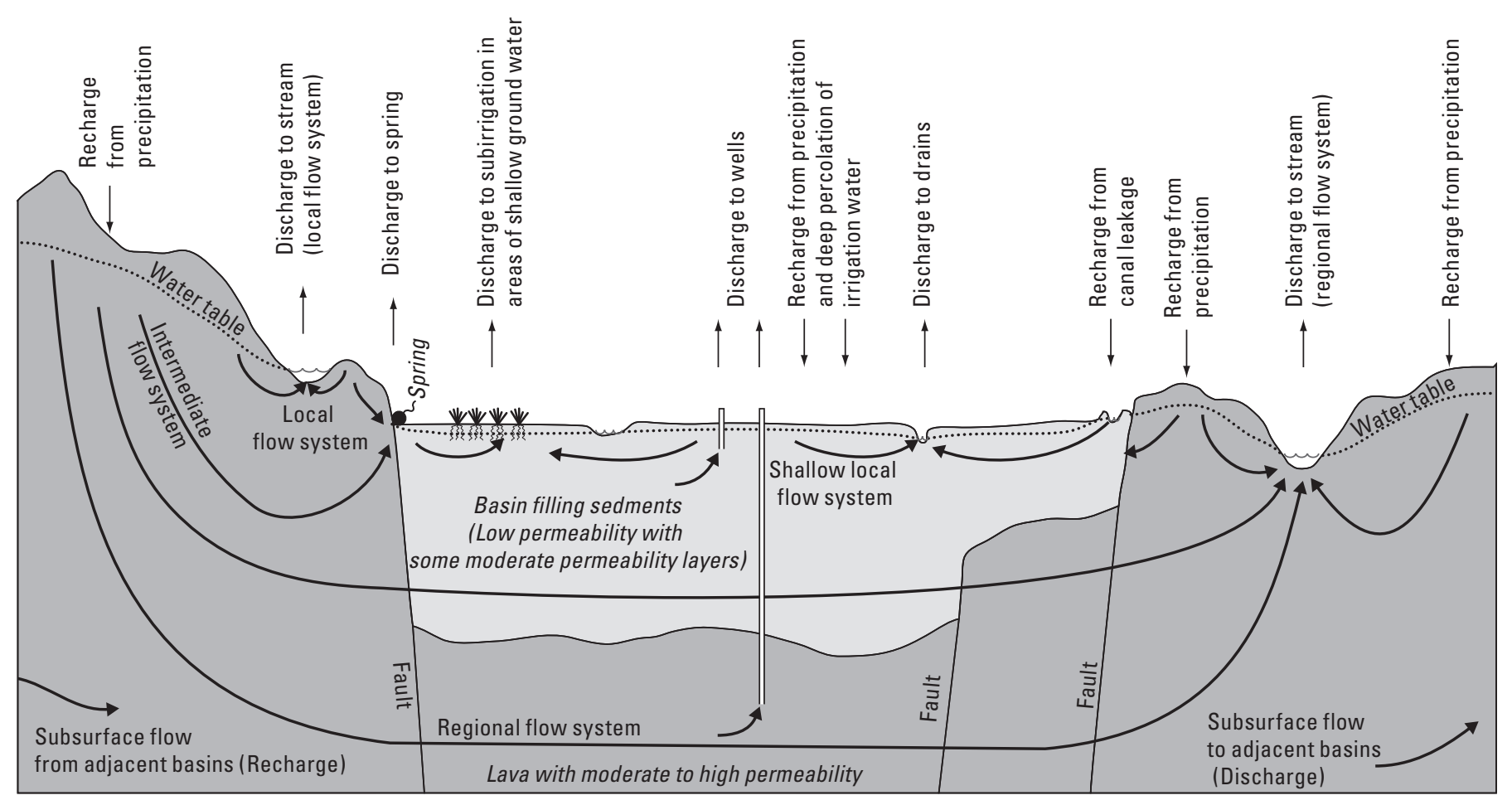

NOT TO SCALE

\section{RECHARGE $=$ DISCHARGE \pm CHANGE IN AQUIFER STORAGE}

Figure 6. Schematic representation of sources of ground-water recharge, flow paths, and mechanisms of ground-water discharge in the upper Klamath Basin, Oregon and California.

\section{Ground-Water Recharge}

Ground water originates as precipitation. Recharge is generally greatest in upland areas where the largest amount of precipitation occurs. The principal recharge areas in the upper Klamath Basin are the Cascade Range and uplands within and on the eastern margin of the basin. Only a fraction of the water that falls as precipitation, however, makes it to the groundwater system. Most either is returned to the atmosphere through evaporation from vegetative surfaces and transpiration by plants, or runs off. In areas where soils and underlying bedrock have low permeability, infiltrating precipitation tends to flow to streams. Such areas typically have well developed stream networks. In areas where soils and underlying bedrock are highly permeable, for example the young volcanic landscapes of the Cascade Range, water infiltrates more easily to the ground-water system. Young volcanic areas often have poorly developed stream networks as a result. Water that percolates through the soil to a depth beneath the root zone potentially can become ground water.
Although direct infiltration of precipitation is the principal source of recharge in the upper Klamath Basin, there are other sources. Stream leakage can be a source of groundwater recharge in areas where the elevation of the stream is higher than the water table and the streambed is permeable. For example, streams that enter the Klamath Marsh area from the Cascade Range in the northern part of the study area generally lose much or all of their flow into the highly permeable soil as they flow onto the pumice plain. No major streams in the upper Klamath Basin, however, are known to lose regionally significant water in this manner, and stream leakage probably is not a substantial source of recharge on a regional scale in the basin.

Irrigation activities also can result in artificial groundwater recharge. Irrigation canals typically lose some water to the shallow parts of the ground-water system. No measurements of canal leakage rates in the upper Klamath Basin were available or made during this study, but measurements exist for other areas. Canal leakage rates 
determined from ponding studies range from less than 1 to greater than $20\left(\mathrm{ft}^{3} / \mathrm{s}\right) / \mathrm{mi}$ in the upper Deschutes Basin, directly to the north of the Klamath Basin (Gannett and others, 2001). The large rates are from unlined canals in fractured lava. Rates in areas underlain by sedimentary deposits commonly range from less than 1 to $3\left(\mathrm{ft}^{3} / \mathrm{s}\right) / \mathrm{mi}$. Canal leakage rates in the Methow Valley of Washington range from 1.0 to $10.7\left(\mathrm{ft}^{3} / \mathrm{s}\right) / \mathrm{mi}$, and average $1.8\left(\mathrm{ft}^{3} / \mathrm{s}\right) / \mathrm{mi}$ (Konrad, 2003). Canal bed materials there include glaciofluvial deposits, colluvium, clay, and bedrock. In addition to canal leakage, water applied to fields can percolate beneath the root zone and into the shallow parts of the ground-water system. The amount of deep percolation of irrigation water depends on the irrigation method. Gannett and others (2001) estimated ground-water recharge from deep percolation of irrigation water in the upper Deschutes Basin to be about 49,000 acre$\mathrm{ft} / \mathrm{yr}$, or about 11 percent of the estimated water deliveries. Studies in the Amargosa Desert in Nevada resulted in estimates of deep percolation ranging from 8 to 16 percent of applied water (Stonestrom and others, 2003). No data are available to determine the amount of ground-water recharge from canal leakage and deep percolation of irrigation water in the upper Klamath Basin. However, ground-water recharge from irrigation activities is indicated because the water table in the shallow aquifers in the Project area rises during the irrigation season, and 2001 measurements showed the shallow water table declined when irrigation was severely curtailed in the Project area. Moreover, some deep irrigation wells also respond when canals of the Klamath Project start flowing in the spring (Bill Ehorn, California Department of Water Resources, written commun., 2002), indicating some recharge takes place, at least locally, to the deeper parts of the groundwater system from irrigation-related activities. Most irrigation in the upper Klamath Basin occurs in alluvial stream valleys and lake basins, and these areas are commonly crisscrossed by drains. Much of the water recharged to the shallow parts of ground-water system by irrigation activities likely discharges to the drain system (or streams) after traveling underground only a short distance (probably less than thousands of feet). Data are insufficient to estimate net regional ground-water recharge from irrigation activities in the upper Klamath Basin; however, the low permeability of the lake sediments that underlie most of the Klamath Project area suggests that ground-water movement from the water table in the Project area to the deeper, regional ground-water system is somewhat restricted and that canal leakage and deep percolation of irrigation water probably are not a significant source of recharge to the regional ground-water system.

Ground-water recharge cannot be directly measured at a regional scale. Regional ground-water recharge can be estimated, however, by measuring ground-water discharge, which can be measured or estimated with reasonable accuracy. Equation 2 shows that ground-water recharge to a system is equal to the discharge plus or minus any changes in storage. The long-term change in ground-water storage in the upper
Klamath Basin (as indicated by long-term water level data) is negligible compared to the annual ground-water budget, allowing recharge to be estimated by measuring or estimating components of discharge.

The principal avenues of ground-water discharge in the upper Klamath Basin are discharge to streams, evapotranspiration by plants with roots that penetrate to the water table (in a process known as "subirrigation"), and pumping. Ground-water discharge to streams is estimated to average about 1.8 million acre-ft/yr, or about $2,400 \mathrm{ft}^{3} / \mathrm{s}$.

Ground-water pumping in 2000, prior to the rapid increase starting in 2001, is estimated to have been about 0.15 acre-ft/yr. Ground-water discharge through subirrigation in areas where the water table is close to land surface is difficult to estimate because it often occurs in wetlands where water comes from both ground- and surface-water sources. Total evapotranspiration from Upper Klamath Lake and surrounding wetlands, the Tule Lake and Lower Klamath Lake Refuge wetlands, and Klamath Marsh is estimated to be roughly 0.7 million acre-ft/yr (table 3), a large amount of this, however, is supplied by surface water. Therefore, ground-water discharge through subirrigation is likely small compared to discharge to streams.

Given that regional-scale long-term changes in groundwater storage are small, average recharge to the regional ground-water system is assumed to be approximately equal to the estimated ground-water discharge to streams and wells of about 2 million acre-ft/yr (rounded up to reflect some evapotranspiration directly from the water table). This figure does not include recharge from irrigation activities in the Project or subsurface discharge to or recharge from adjacent basins.

Ground-water recharge from precipitation, therefore, is about 20 percent of the total precipitation basinwide. The exact percentage, however, varies spatially and temporally. Gannett and others (2001), working with a water-balance model developed by Boyd (1996), noted that ground-water recharge in the upper Deschutes Basin ranges from 5 to 70 percent depending on location. In the Cascade Range, where there is a large amount of precipitation, which far exceeds potential evapotranspiration, a large percentage enters the ground-water system. In contrast, only a small fraction of the precipitation recharges ground water in the very dry interior parts of the basin, where precipitation is a fraction of the potential evapotranspiration. Temporally, recharge varies seasonally and from year to year. Recharge from precipitation in mountainous areas, like the Cascade Range, occurs during spring snowmelt. Recharge from irrigation occurs during the irrigation season. The timing of recharge pulses from these sources can be seen in water level data from wells (discussed later). Recharge will vary from year to year depending on the annual precipitation. Estimated basinwide recharge in the upper Deschutes Basin ranged from less than $3 \mathrm{in} / \mathrm{yr}$ during the drought years of 1977 and 1994 to more than $20 \mathrm{in} / \mathrm{yr}$ in 1982 (Gannett and others, 2001). 


\section{Ground-Water Discharge to Streams}

Water flows to streams through a variety of mechanisms. For convenience, streamflow is often broken into three components: surface runoff, interflow, and baseflow. The surface runoff component reaches the stream through overland flow or flow in the top of the soil profile. Such flow is typically rapid, and is responsible for the rapid rise in streamflow during and immediately after storms or snowmelt. Interflow, also termed subsurface runoff, reaches the stream through flow in unsaturated or temporarily saturated zones in the upper soil layers. Baseflow generally is considered to be fed by ground-water discharge. Baseflow can originate from a variety of scales of ground-water flow, ranging from short, local flow paths to long and deep regional flow paths. Baseflow generally is the source of water in streams in the late summer and fall, when little or no precipitation or remaining snow are available to provide surface runoff or interflow.

The flow in some streams in the upper Klamath Basin consists entirely of ground-water discharge. Such streams are characterized by consistent year-round flow with little seasonal variability. An example of a typical ground-water-fed stream is the Wood River at Fort Klamath (USGS streamgaging station number 11504000), which during the period of record from 1913 to 1936 had a mean annual flow of $215 \mathrm{ft}^{3} / \mathrm{s}$ and a standard deviation of daily mean flows of only $58 \mathrm{ft}^{3} / \mathrm{s}$. The mean September flow of the Wood River was $199 \mathrm{ft}^{3} / \mathrm{s}$, or about 93 percent of the mean annual flow. Other streams, in contrast, have a relatively small component of ground-water discharge and consist predominantly of surface runoff. Such streams have large seasonal variability, with high flows during and immediately after rainfall or snowmelt followed by low or no flow during the dry periods of the year. Stream gaging data from the Sycan River below Snake Creek near Beatty (station 11499100) provide an example of a stream with a large component of surface runoff. During the period of record from 1973 to 2003 the Sycan River at this location had a mean annual flow of $152 \mathrm{ft}^{3} / \mathrm{s}$ and a standard deviation of daily mean flows of $282 \mathrm{ft}^{3} / \mathrm{s}$. The mean September flow of the Sycan River here is only $23 \mathrm{ft}^{3} / \mathrm{s}$, or about 15 percent of the mean annual flow. Most streams in the Klamath Basin exhibit all three components of discharge throughout the year. Identifying the amount of streamflow supplied by ground-water discharge is problematic during times of the year when there is substantial contribution from overland flow and interflow. However, in the late summer and fall, when there is scant precipitation and snow has melted, streamflow is composed largely of ground-water discharge. Exceptions to this generalization include streams receiving substantial irrigation return flow or water from reservoir releases. Where these exceptions do not occur, or can be accounted for, streamflow during the fall months (September-November) when precipitation, runoff, and interflow are nearly absent provides a good estimate of baseflow or ground-water discharge.
The location and quantity of ground-water discharge entering the stream network was estimated at numerous locations throughout the upper Klamath Basin (table 6, at back of report). Estimates are, for the most part, based on measurements of actual spring discharge or streamflow during late summer and fall. For some spring-dominated streams (Spring Creek, for example), streamflow over the entire year could have been used to determine ground-water discharge. However, to maintain consistency in the analysis, data from the fall months were used exclusively where possible. Some of the ground-water discharge estimates were based on the OWRD natural streamflow analysis for the Klamath Basin (Cooper, 2004). These estimates represent the median or typical flow for a particular month over a 30-year base period, from 1958 to 1997. For this study, the work was supplemented by additional analysis, streamflow measurements, and fieldwork performed from 1997 to 2005 . When possible, the estimate represents the typical ground-water discharge for the fall over a base period from 1958 to 1987. Selection of this base period is detailed in Cooper (2002). However, sometimes the available data at a location was insufficient to generate an estimate that represented the base period. In those cases, the estimate may not reflect the long-term average conditions. The data sources and techniques used to estimate ground-water discharge are listed for each reach in table 6.

Estimates of ground-water discharge have inherent uncertainty. One source of uncertainty is the streamflow measurements on which they are based. For example, records from stream gages are rated "excellent" when 95 percent of the daily discharge values are within 5 percent of the true value, "good" when 95 percent of the daily discharge values are within 10 percent of the true value, and "fair" when 95 percent of the daily discharge values are within 15 percent of the true value. Some of the estimates in table 6 are based on regression models where estimates are derived by comparing streamgage data that span periods that are short or outside of the base period, or miscellaneous measurements with longterm flow data from streams determined to be hydrologically representative of the stream in question. Regression models are another source of uncertainty. A detailed description of the regression analyses is available in Cooper (2004). Some ground-water discharge estimates in table 6 are based on single measurements or averages of multiple measurements and are not shifted to the base period. Consequently, there is uncertainty as to the degree to which they represent long-term average conditions. An assessment of the level of certainty of each estimate is included in table 6, and most figures are rounded to two significant figures. Rates of discharge at the large spring complexes responsible for most of the groundwater discharge in the basin are generally well known and have the least associated uncertainty. Although there may be uncertainty in the estimates of long-term average ground water discharging at certain locations, the presence of discharge at the listed locations is well established, and the general distribution and magnitude of ground-water discharge in the upper Klamath Basin is well understood. 


\section{Geographic Distribution of Ground-Water Discharge to Streams}

Ground-water discharge to major streams was estimated in five subregions. The subregions were based on the USGS 4th field Hydrologic Unit Code (HUC) with further analysis by smaller stream groupings in each subregion, based largely on 5th field HUCs. The five subregions are (1) Sprague River, (2) Williamson River, (3) Upper Klamath Lake, (4) Lost River, and (5) Klamath River.

The values in table 6 represent the estimated long-term average ground-water discharge (gains) to all major streams in the stream system, and therefore reflect most of the ground-water discharge to the streams. Average ground-water discharge into the stream network of the upper Klamath Basin (above Iron Gate Dam) totals about 2,400 $\mathrm{ft}^{3} / \mathrm{s}$ (1.8 million acre-ft/yr). This estimate includes gains to the Lost River, which are at least $195 \mathrm{ft}^{3} / \mathrm{s}$, but may be higher due to unknown gains to the river below Lost River Diversion Channel. Ground-water discharge directly to Lower Klamath Lake and the Tule Lake Sump was not estimated due to insufficient data.

Ground-water discharge varies from subbasin to subbasin, reflecting precipitation patterns as well as geologic controls on ground-water movement (fig. 7). The largest groundwater discharge areas are in the Lower Williamson, Wood River, Upper Klamath Lake, and Klamath River subbasins. Besides Upper Klamath Lake and parts of the Klamath River subbasins, the specific locations of ground-water discharge are largely known and the quality of the estimates is considered good. Estimates of ground-water discharge to marshes have larger uncertainty due to difficulties with mass balances.

\section{Temporal Fluctuations in Ground-Water Discharge to Streams}

Ground-water discharge to streams is not constant, but fluctuates with time in response to variations in recharge and, in some circumstances, ground-water pumping. In the upper Klamath Basin, varying recharge is the predominant cause of ground-water discharge fluctuations. Recharge varies in response to seasonal weather patterns (wet winters versus dry summers), as well as in response to decadal-scale drought cycles and longer-term climate trends. A graph of total annual precipitation at Crater Lake National Park (fig. 8) shows the year-to-year variations in precipitation and longer-term variations. A useful way to look at long-term climate cycles is a graph of the cumulative departure from average (fig. 8). Water-table fluctuations and variations in discharge often mimic this pattern. The precipitation at Crater Lake over the past several decades exhibits the pattern observed at other precipitation stations throughout the region and in streamflow and ground-water levels as well. Most notable is the dry period in the 1930s and early 1940s followed by a wet period in the late 1940s and 1950s. The pattern from the 1960s to the present is characterized by decadal scale drought cycles superimposed on an apparent drying trend. Generally dry periods include 1966 to 1968,1976 to 1981,1987 to 1994 , and 2000 to 2005.

The timing and magnitude of ground-water discharge fluctuations can vary depending on the scale of the flow system involved. Small-scale systems with flow paths of less than a few miles and catchments of 1 to $10 \mathrm{mi}^{2}$, for example the flow system feeding the springs at the head of Annie Creek near Crater Lake, fluctuate in response to present-year precipitation. Such features will have large discharge during wet years and small discharge during dry years. In contrast, large-scale flow systems with flow paths of tens of miles and catchments of hundreds of square miles, such as the lowelevation regional spring complexes feeding the Wood River or Spring Creek, respond more to longer-term climate signals. Instead of reflecting the year-to-year precipitation like small springs, large-scale systems tend to integrate precipitation over several years and follow a pattern similar to the cumulative departure from average precipitation (fig. 8).

Several techniques were used in this study to determine or evaluate variations in ground-water discharge. Ground-water discharge fluctuations were in some cases measured directly by gaging stations on streams that are solely spring fed. Such data are rare in the upper Klamath Basin. Ground-water discharge fluctuations were calculated in some areas where two or more gaging stations with overlapping records bracket a stream reach to which ground-water discharges. These types of data are available for several stream reaches in the upper Klamath Basin. The analyses in such situations, however, were complicated by ungaged diversions or tributary inflow. Information on ground-water discharge fluctuations also was provided by sets of miscellaneous streamflow measurements along reaches where ground water discharges. Many streams include surface runoff as well as a large component of groundwater discharge. Comparing late summer or fall flows (when streamflow is commonly composed largely of ground-water discharge) from year to year can provide useful information on temporal variations in ground-water discharge.

\section{Ground-Water Discharge to Streams by Subbasin}

\section{Sprague River Subbasin—Geographic Distribution of Ground-Water Discharge}

The Sprague River subbasin encompasses the entire drainage above its confluence with the Williamson River, including the Sycan River drainage basin (fig. 7). The subbasin includes many runoff-dominated streams in the volcanic upper watersheds as wells as isolated springs and ground-water-dominated streams in the sediment filled valleys in the lower reaches of tributaries and along the main stem. 


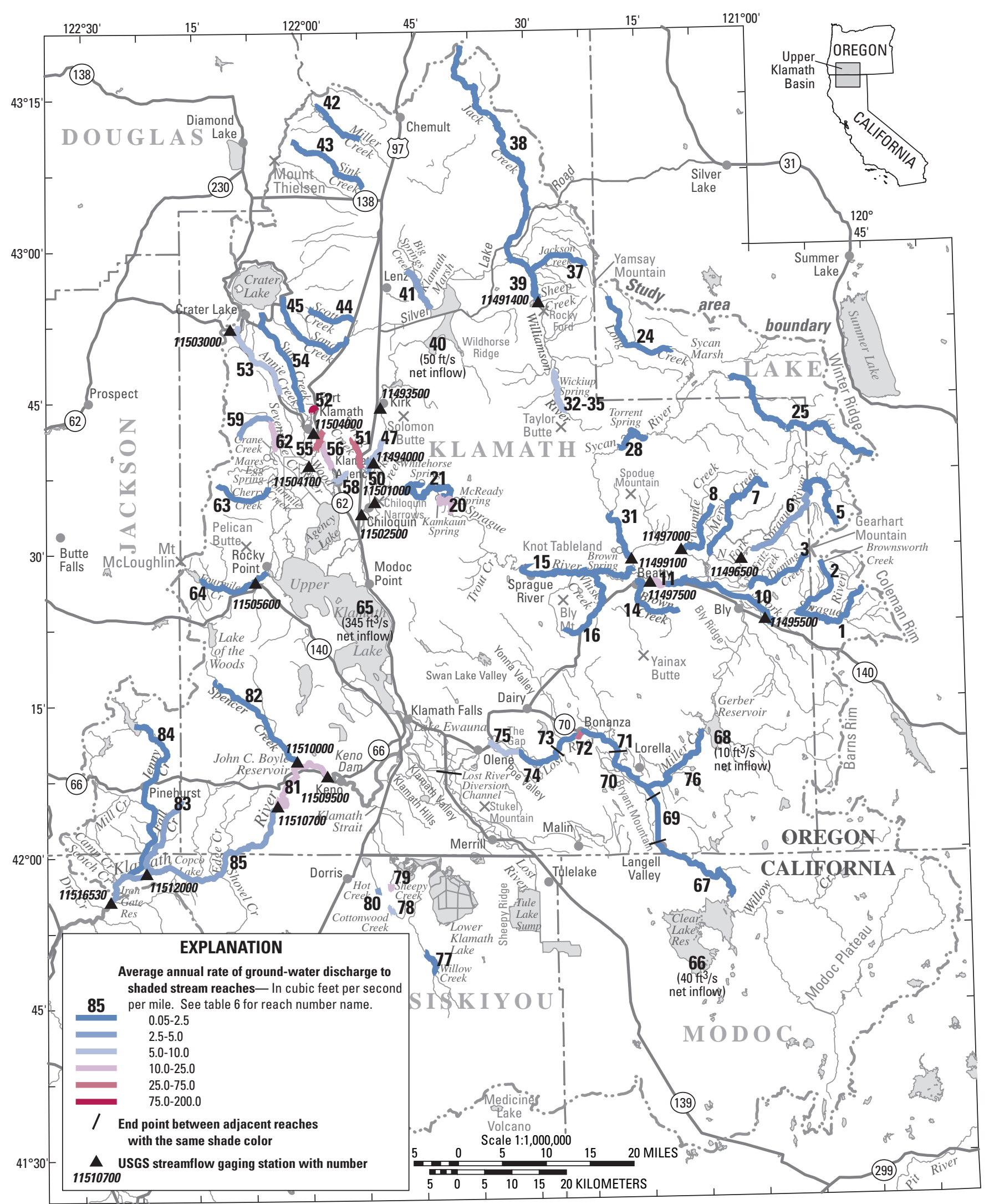

See table of contents for mapping sources

Figure 7. Principal areas of ground-water discharge to streams and major springs in the upper Klamath Basin, Oregon and California, and selected stream-gaging stations. Shading along main stem reaches represents ground-water discharge (in cubic feet per second per mile) averaged along the entire shaded reach. The actual location of ground-water discharge may be localized. Shading along headwater streams represents the ground-water discharge averaged over the shaded reach and includes ground-water discharge to tributaries. See table 6 for detailed descriptions of measurement locations. 


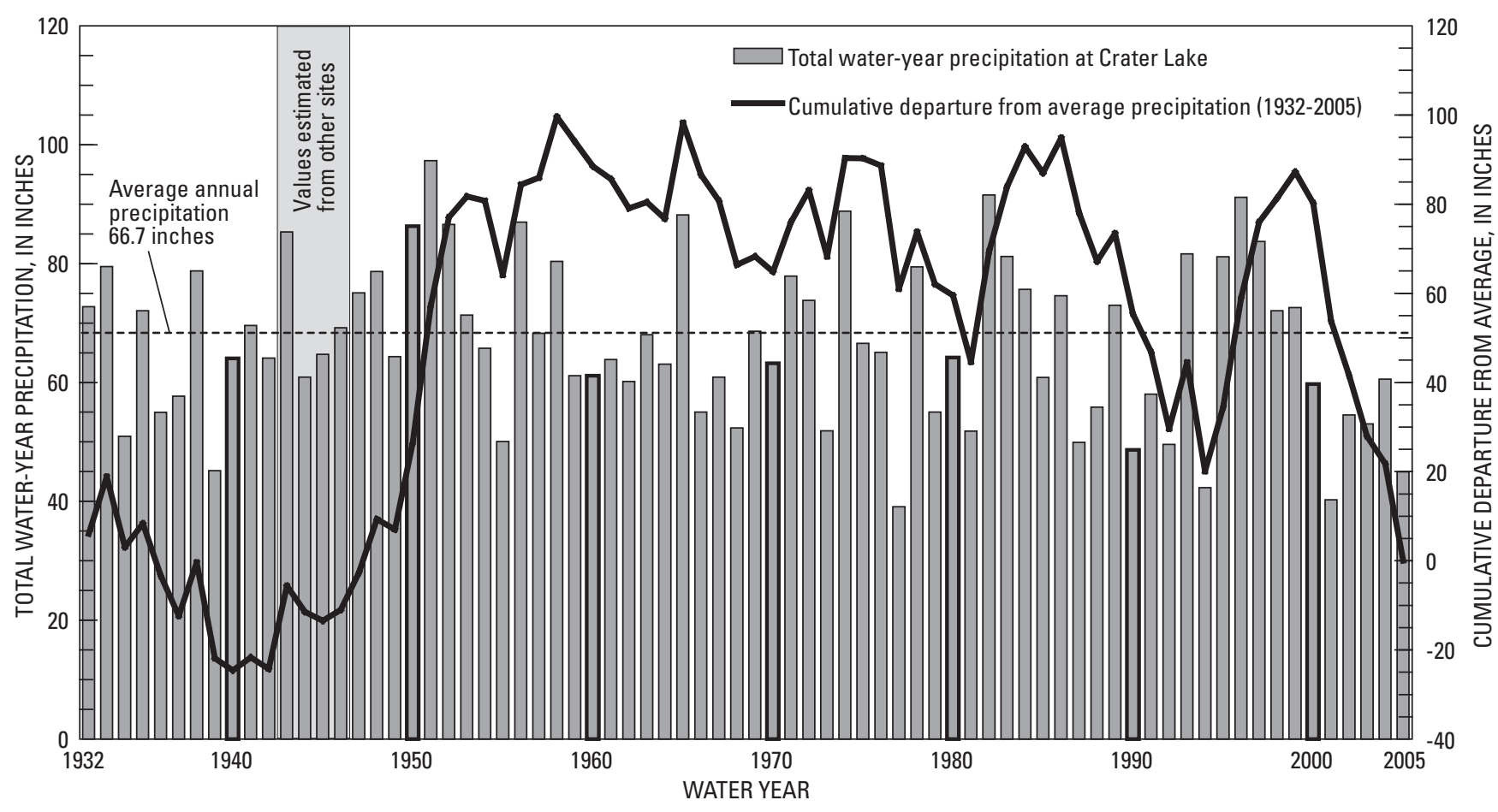

Figure 8. Annual precipitation at Crater Lake National Park, Oregon, and the cumulative departure from average precipitation from 1932 to 2005. (Data from Western Regional Climate Center, 2006.)

The Sprague River responds relatively quickly to precipitation and snowmelt events, with peaks commonly exceeding 2,500 $\mathrm{ft}^{3} / \mathrm{s}$ in April or May at the gaging station near Chiloquin (station 11501000). Mean monthly discharge at this location averages 1,300 ft $3 / \mathrm{s}$ during April and $300 \mathrm{ft}^{3} / \mathrm{s}$ during October. Major hydrologic features of the subbasin include the North and South Forks of the Sprague River, the Sycan River and Marsh, and Kamkaun Springs.

The Sprague River originates along the flanks of Gearheart Mountain and Coleman Rim in the highlands along the central-eastern edge of the upper Klamath Basin. From these highlands, the North and South Forks gain water from numerous tributaries as they flow down mountain canyons to the upper Sprague River Valley, above Beatty Gap. The hydrologic regimes of the North and South Forks have a pronounced runoff component and similar hydrographs near the uplands, with peaks occurring during snowmelt in the spring. However, above the Sprague River Valley, the North Fork gains significant ground water, whereas the South Fork does not.

From the confluence of the North and South Forks, the Sprague River meanders downstream through the narrowing upper Sprague River Valley, until it passes through Beatty Gap into the lower valley. Gains due to ground-water inflow occur in the upper valley, which contains both drained and un-drained wetlands. More ground-water discharge occurs to a spring complex (locally known as Medicine Springs) just downstream of Beatty Gap. From here, the Sprague River meanders through the lower Sprague River Valley for $75 \mathrm{mi}$, to its confluence with the Williamson River.
Aside from the runoff-driven Sycan River, tributaries north of the river and downstream of Beatty Gap are limited to a few unnamed ephemeral creeks draining the Knot Tableland and a few small springs near the mouth of the Sycan River. South of the river are four perennial and several ephemeral creeks. Three of the perennial creeks (Spring, Brown, and Whisky Creeks) are largely ground-water fed and lack a significant runoff component (fig. 7). (Note: The Spring Creek that is tributary to the Sprague River is too small to show at the scale of figures in this report. It enters the Sprague River just east of Brown Creek. The other Spring Creek mentioned in this report is tributary to the Williamson River.) An additional, but smaller amount of ground water discharges to Trout Creek as well as a few small springs near the mouth of Whisky Creek. Two large, isolated spring complexes, KamkaunMcReady and Whitehorse, farther downstream, are the only other ground-water discharge areas in the lower valley.

Ground-water discharge to the North and South Forks of the Sprague River (above the valley) was estimated using data from gaging stations with short periods of record and miscellaneous measurements made from 1992 to 2002. The spatial distribution of gains is relatively well known in the reaches and main tributaries of the North and South Forks (fig 7). However, the locations of specific springs have not been identified in either subbasin. Continuous and miscellaneous streamflow measurements were analyzed using index regression techniques on the North and South Forks to improve understanding of the temporal variability of groundwater discharge. Gains to the South Fork above the valley are 
about $24 \mathrm{ft}^{3} / \mathrm{s}$, with most ground-water discharge occurring above the confluence with Brownsworth Creek (table 6). On the basis of regional regression, Deming and Fritz Creeks are estimated to contribute an additional $5 \mathrm{ft}^{3} / \mathrm{s}$ of ground-water discharge to the system. Ground-water discharge to the North Fork is about $92 \mathrm{ft}^{3} / \mathrm{s}$, with one-third of the flow originating from Fivemile and Meryl Creeks. There are no direct inputs to the lower $10 \mathrm{mi}$ of the North Fork.

The spatial distribution of ground-water discharge in the Upper Sprague River Valley (from the confluence of the North and South Forks to Beatty Gap) is more uncertain. Although there are no identified springs in the area, synoptic measurements show about $52 \mathrm{ft}^{3} / \mathrm{s}$ of ground-water discharge along the 20-mi reach, including the main stem between Beatty Gap and the confluence of the North and South Forks, and the lower $11 \mathrm{mi}$ of the South Fork (table 6).

The Lower Sprague Valley is defined as the area between the mouth of the river and Beatty Gap. The locations of gains in this valley are well known from numerous sets of synoptic measurements. Gains total about $150 \mathrm{ft}^{3} / \mathrm{s}$. Ground water discharges directly to the river from the springs below Beatty Gap, Kamkaun, McReady, and White Horse Springs, as well as through tributaries at Whisky, Spring, and Brown Creeks. Even though ground-water discharge occurs at discrete locations, the locations can be lumped into two areas in the lower valley: (1) the valley between Whisky Creek and Beatty Gap ( $\left.75 \mathrm{ft}^{3} / \mathrm{s}\right)$, and (2) the valley near Kamkaun, Whitehorse, and McReady Springs ( $73 \mathrm{ft}^{3} / \mathrm{s}$ ) (fig. 7 and table 6). The temporal and spatial distribution of ground-water discharge in this subbasin is well understood given the multiple synoptic measurements made when the streamflow recorded at Chiloquin (11501000) was near the long-term average flow.

The Sycan River is the other main tributary to the Sprague River, but it contributes relatively little baseflow (historically about $30 \mathrm{ft}^{3} / \mathrm{s}$ ) given its drainage area of $563 \mathrm{mi}^{2}$. The Sycan River is a snowmelt-runoff dominated stream, with peak flows occurring during the spring freshet (March-June). Monthly mean flows at the gaging station near Beatty indicate spring runoff flows are significant $\left(400 \mathrm{ft}^{3} / \mathrm{s}\right)$, whereas fall baseflows are minimal. Most tributaries to the Sycan River are ephemeral, contributing flow only during snowmelt or precipitation events, with ground water being a minor contributor to streamflow.

The Sycan River originates in the forested uplands east of Sycan Marsh on the western side of Winter Ridge, and is the only perennial tributary to Sycan Marsh from the east. At this location, the river has the characteristics of a runoffdominated stream, with peak flows occurring during spring to early summer and comparatively small baseflows in the fall. Long Creek is the main tributary west of Sycan Marsh and has lower peak flows, but a larger component of ground-water discharge than the Sycan River above the marsh, even though the watershed has about one-half the area. Ground-water discharge to the Sycan River and Long Creek above Sycan Marsh totals about $24 \mathrm{ft}^{3} / \mathrm{s}$.
Preliminary hydrologic analysis of Sycan Marsh indicates that it is predominantly a surface-water dominated wetland. However, some ground water discharges to the marsh from numerous springs associated with a fen at the northern part of the marsh. Other than the Sycan River and Long Creek, most tributaries to the marsh are ephemeral, contributing flow only during snowmelt or precipitation events. Nested piezometers show a downward head gradient in most of the marsh, indicating that water moves from the surface downward (Leslie Bach, The Nature Conservancy, oral commun., 2005), which suggests that the marsh is an area of ground-water recharge.

The relation between the ground-water system and Sycan Marsh was evaluated by means of a water balance. Surface inflows and outflows from gaging station data were adjusted to the base period and then combined with precipitation and marsh evapotranspiration estimates to derive the ground-water gains or losses. The water balance resulted in a slight loss $(-10$ to $\left.-20 \mathrm{ft}^{3} / \mathrm{s}\right)$, suggesting that the marsh may be a ground-water recharge area. This is consistent with the downward head gradient seen in piezometer nests. This water balance has a large uncertainty because of the evapotranspiration and soil moisture terms.

The lower Sycan subbasin (area between the mouth and Sycan Marsh) has relatively little ground-water discharge $\left(21 \mathrm{ft}^{3} / \mathrm{s}\right)$, which occurs at two locations. The first is an isolated spring, Torrent Spring (12 ft $3 / \mathrm{s}$ ), $10 \mathrm{mi}$ downstream of Sycan Marsh. The second is from a number of springs, seeps, and creeks along the lower $10 \mathrm{mi}$ of the river (fig. 7 and table 6).

\section{Sprague River Subbasin-Temporal Variations in Ground-Water Discharge}

Quantifying the temporal variations in ground-water discharge in the Sprague River subbasin is difficult due to a lack of data. Ground water discharges to a variety of spring complexes and spring-fed streams in the basin. Present gaging stations in the Sprague River subbasin are not well suited to provide direct measurement of ground-water discharge variations because of the effects of diversion. However, some inferences can be made by evaluating late-season flows at gages on the main stem with long periods of record. Gaging stations at Beatty and near Chiloquin provide useful information. However, diversions, tributaries, and probable irrigation return flow affect measurements at these locations. At Beatty, September mean discharge, the best proxy available for baseflow above that location, varied from about $80 \mathrm{ft}^{3} / \mathrm{s}$ to about $180 \mathrm{ft}^{3} / \mathrm{s}$ during the period of record from 1954 to 1991 . September mean discharge near Chiloquin (fig. 9) ranged from less than $150 \mathrm{ft}^{3} / \mathrm{s}$ to greater than $350 \mathrm{ft}^{3} / \mathrm{s}$. Like other streams, the variations in September mean stream discharge generally follow climate cycles, with the highest flows following multiple wet years and the lowest flows following multiple dry years. 


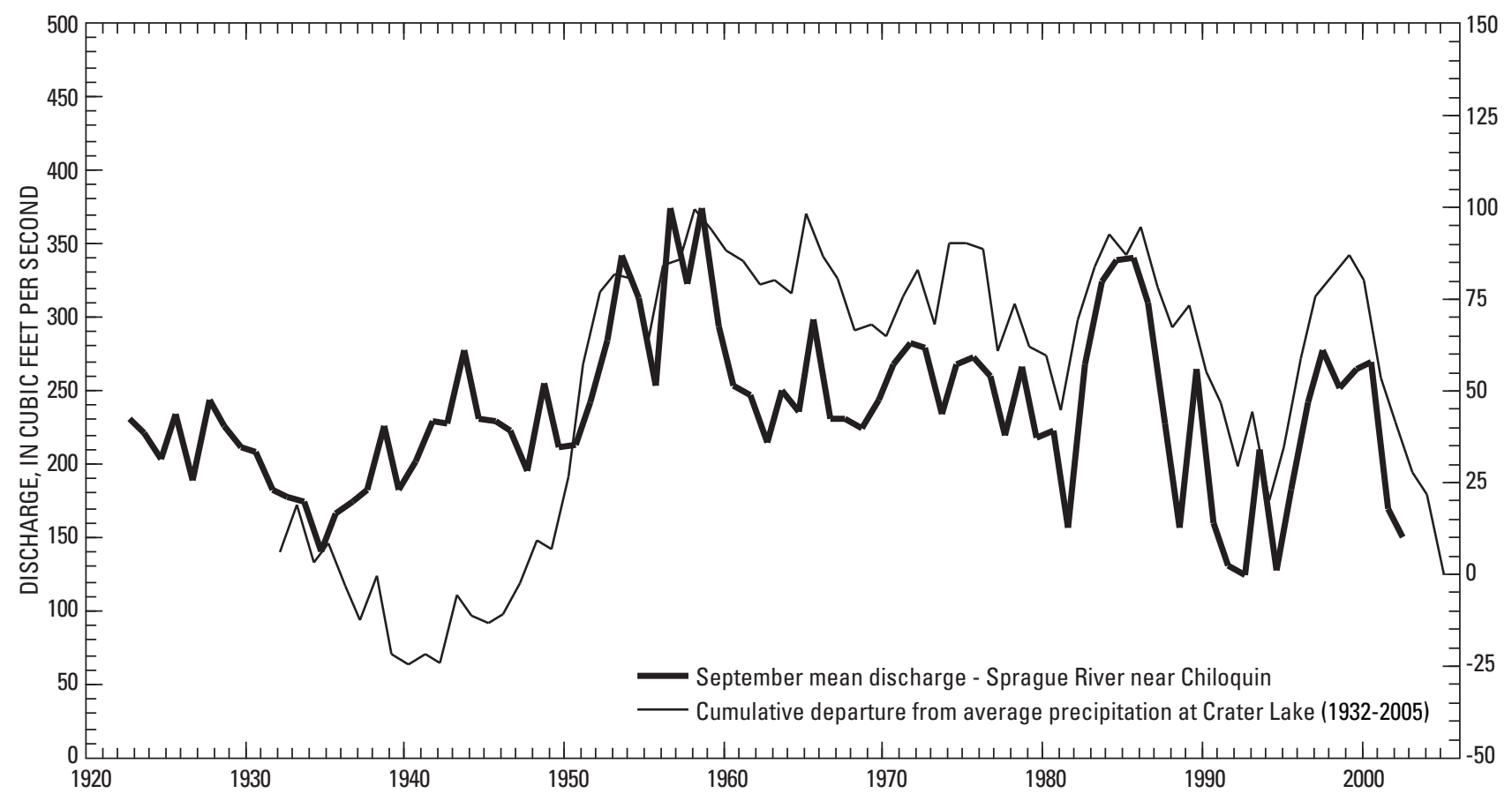

Figure 9. September mean discharge of the Sprague River near Chiloquin, Oregon (USGS gaging station number 11501000), and the cumulative departure from average precipitation at Crater Lake, Oregon.

\section{Williamson River Subbasin-Geographic Distribution of Ground-Water Discharge}

The Williamson River originates from springs just east and south of Taylor Butte. From its source, the river flows almost due north through a wide, sediment-filled valley for 35 mi before flowing west for $5 \mathrm{mi}$, where it historically spread over a delta into Klamath Marsh. The natural channel at the entrance to the marsh no longer exists, however, because the river has been diked and redirected. Most tributaries to the upper Williamson River originate along the flanks of Yamsay Mountain and the ridge to the south and are ephemeral, with flows occurring during spring snowmelt. However, significant springs contribute water directly to the upper Williamson River, which, as a result, has robust baseflow in addition to a runoff signal in its hydrograph during spring (fig. 10). Data recorded below Sheep Creek (station 11491400) indicates that flows average about $90 \mathrm{ft}^{3} / \mathrm{s}$ during spring and $57 \mathrm{ft}^{3} / \mathrm{s}$ in fall (table 6).

The spatial distribution of ground-water discharge to the Upper Williamson River has been largely identified from synoptic measurements (fig. 7 and table 6). Ground water discharges directly into the Upper Williamson River at several large springs upstream from the gage below Sheep Creek (station 11491400) and averages $54 \mathrm{ft}^{3} / \mathrm{s}$, with Wickiup Spring $\left(24 \mathrm{ft}^{3} / \mathrm{s}\right)$ being the largest single contributor (table 6). An additional $26 \mathrm{ft}^{3} / \mathrm{s}$ of gain occurs between Sheep Creek and the marsh. Total ground-water discharge in the area is about $80 \mathrm{ft}^{3} / \mathrm{s}$. The knowledge of the temporal variations in ground-water discharge to the Upper Williamson River is good upstream from the Sheep Creek gaging station owing to data from the long-term records at that site. However, between Sheep Creek and Klamath Marsh, no continuous streamflow record exists.

The only other perennial tributary that reaches Klamath Marsh is the spring-fed Big Springs Creek. However, even this creek may go dry during successive drought years (Newcomb and Hart, 1958). Surprisingly, Big Springs Creek shows a relatively flashy response to snowmelt and rainfall events that is atypical for spring-fed streams. Presumably, this rapid response is due to the ability of local rainfall and snowmelt to move easily through the very permeable pumice soils. Water in most other perennial streams draining to the marsh from the eastern side of the Cascades infiltrates into the pumice plain before reaching the marsh. Water in Sand and Scott Creeks would reach the marsh, but it is diverted to irrigate pasture lands on the western edge of the marsh.

Ground-water discharge to Big Springs, Sand, and Scott Creeks, and other tributaries west of Klamath Marsh, totals about $78 \mathrm{ft}^{3} / \mathrm{s}$. About $12 \mathrm{ft}^{3} / \mathrm{s}$ of the total discharge is to Miller and Sink Creeks, which lose their flow through infiltration into the pumice plain before reaching the marsh. Discharge to these streams was estimated from miscellaneous measurements and short-term gaging station data using index regression. All other tributaries are either ephemeral, or infiltrate into the pumice plain. 


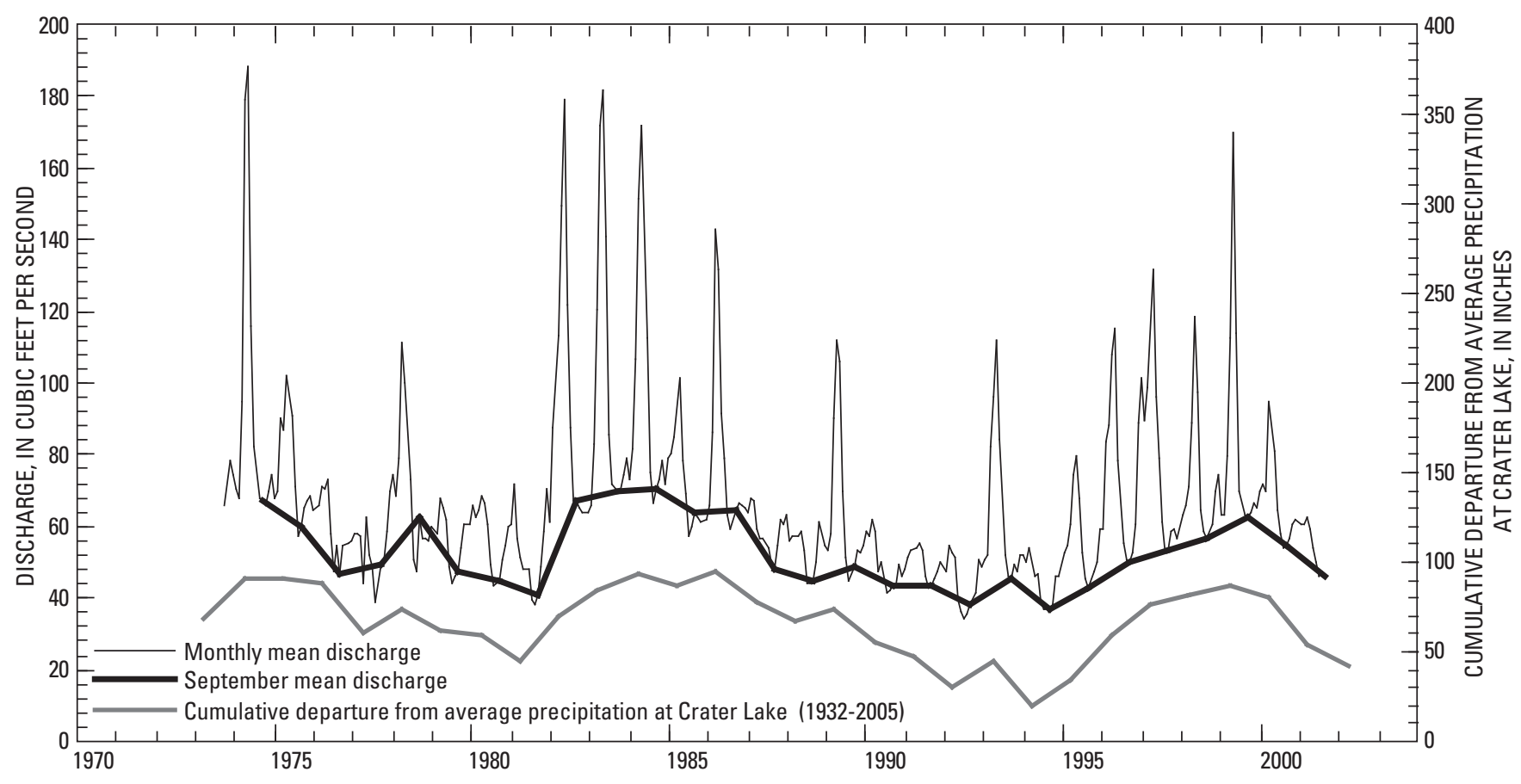

Figure 10. Monthly mean discharge and September mean discharge of the Williamson River below Sheep Creek near Lenz, Oregon (USGS gaging station number 11491400), and the cumulative departure from average precipitation at Crater Lake, Oregon.

A mass balance indicates that average net annual groundwater discharge directly to Klamath Marsh was approximately $50 \mathrm{ft}^{3} / \mathrm{s}$ between 1971 and 2000. This estimate is based on available gage data for tributary inputs, estimates for evapotranspiration, and direct precipitation on the marsh. The analysis assumes that the net change in water stored in the marsh during the 30 -year period was negligible. The spatial distribution of ground-water discharge directly to the marsh is unknown.

The hydrograph of the Williamson River at the outlet of Klamath Marsh near Kirk (station 11493500, not shown) has a runoff signal, presumably from ephemeral tributaries and direct local runoff from the marsh. Flow of the Williamson River at the outlet of the marsh ceases during most summers due to the large amount of evapotranspiration in the marsh.

South of the gaging station near Kirk (altitude 4,483 ft), the Williamson River descends into a narrow, steep canyon as it drops in elevation. Small seeps and springs appear in the canyon walls near an altitude of 4,220 ft. As the river exits the canyon, three spring-fed streams contribute most of the baseflow to the Williamson River: Spring Creek, Larkin Creek, and Larkin Springs. Hydrographs of the Williamson River below these streams and above the Sprague River show a system with a large component of ground-water discharge that responds relatively slowly to precipitation and snowmelt events and that has gradual accession and recession curves. Peak flows commonly exceed $1,000 \mathrm{ft}^{3} / \mathrm{s}$ and usually occur in March. Low flows consistently range near 300 to $350 \mathrm{ft}^{3} / \mathrm{s}$ and occur during summer. Gains to the river due to ground-water discharge below Klamath Marsh occur at Spring Creek (300 $\left.\mathrm{ft}^{3} / \mathrm{s}\right)$, Larkin Creek (10 $\left.\mathrm{ft}^{3} / \mathrm{s}\right)$, Larkin Springs (10 $\left.\mathrm{ft}^{3} / \mathrm{s}\right)$, and miscellaneous small springs $\left(28 \mathrm{ft}^{3} / \mathrm{s}\right)$ above Larkin Spring (table 6).

\section{Williamson River Subbasin-Temporal Variations in Ground-Water Discharge}

About 78 percent of the $67 \mathrm{ft}^{3} / \mathrm{s}$ mean annual discharge of the uppermost Williamson River is composed of ground water. Information on fluctuations in ground-water discharge to the upper Williamson River comes largely from the gage downstream from Sheep Creek (station 11491400) operated since 1974. August-September flow of the upper Williamson River, which is mostly spring discharge, averages $52 \mathrm{ft}^{3} / \mathrm{s}$. Synoptic measurements in November 2002 showed $54 \mathrm{ft}^{3} / \mathrm{s}$ ground-water discharge to the reach (table 6). A graph of monthly mean flows of the Williamson River below Sheep Creek (fig. 10) shows that the base flow, as represented by September mean discharge, varies by a factor of nearly 2 , from 37 to $70 \mathrm{ft}^{3} / \mathrm{s}$. Comparing September mean flows with precipitation at Crater Lake (fig. 10) shows that this variation correlates with climate cycles. A plot of September flow of the Williamson River at Lenz and the cumulative departure from average precipitation at Crater Lake shows a positive linear relation with a correlation coefficient of 0.79 (fig. 11). 


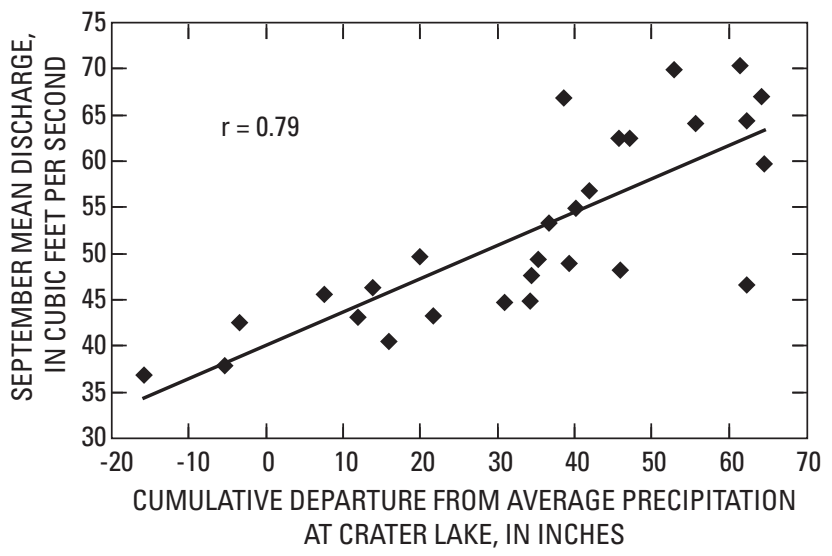

Figure 11. Relation between the September mean discharge of the Williamson River below Sheep Creek near Lenz, Oregon (USGS gaging station number 11491400), and the cumulative departure from average precipitation at Crater Lake, Oregon.

Part of the observed variation in September mean flow could be due to variations in surface-water diversions, which also are correlated with climate, as irrigation demands are less during wet periods and greater during dry periods. Given the small irrigated area above the gage (about 3,000 acres), the probable climate-driven variation in September diversions is small compared to the observed variations in streamflow. This indicates that most of the observed variation in September mean flow can be attributed to fluctuations in ground-water discharge.

Newcomb and Hart (1958) showed that ground-water discharge to Big Springs Creek varies from zero to about 90 $\mathrm{ft}^{3} / \mathrm{s}$ in response to drought cycles. Meinzer (1927) shows the discharge of Big Springs Creek decreasing from 61 to 11.6 $\mathrm{ft}^{3} / \mathrm{s}$ between 1914 and 1925 in a more or less linear manner in response to a general drying climate trend. La Marche (2002) noted that Big Springs Creek also shows seasonal fluctuations in response to annual snow melt. This suggests that Big Springs Creek is fed by a local, possibly perched, flow system.

The area of the lower Williamson River, between the gage at Kirk and the confluence with the Sprague River, is one of the major ground-water discharge areas in the upper Klamath Basin. About 86 percent of the ground-water discharge in this area is to Spring Creek, a short tributary to the Williamson River that is fed entirely by springs. The remaining groundwater discharge is to Larkin Creek, Larkin Springs, and other nearby springs.

Spring Creek is particularly important because it provides much of the flow to the Williamson River, an important source of water to Upper Klamath Lake, during summer. Many measurements of instantaneous streamflow have been made along Spring Creek during the past 100 years by the USGS and OWRD. Spring Creek flow varies with time and correlates with climate (fig. 12). The correlation coefficient between Spring Creek flow and the cumulative departure from average precipitation at Crater Lake between 1932 and 2002 is 0.72 . Spring Creek is unaffected by surface-water diversions, and ground-water pumpage in the area is not enough to cause the observed discharge variations.

A more continuous measure of the ground-water discharge variations in the area can be developed using data from streamflow gages on the Williamson River near Kirk (11493500), the Sprague River near Chiloquin (11501000), and the Williamson River below the Sprague River, near Chiloquin (11502500). If the streamflow at the former two gages is subtracted from the latter, the positive residual (indicating a gain in streamflow between the gages) is due primarily to ground-water discharge, most of which is from Spring Creek. The ground-water discharge in this area, on the basis of September mean flows, averages about $306 \mathrm{ft}^{3} / \mathrm{s}$, and ranges from about 250 to $400 \mathrm{ft}^{3} / \mathrm{s}$. The uncertainty of this estimate (on the basis of estimated gage error) is only about $\pm 30 \mathrm{ft}^{3} / \mathrm{s}$. This analysis is complicated by the fact that there are ungaged diversions from the Sprague River below the gage at Chiloquin, most notably the Modoc Irrigation District canal. Diversion records for the Modoc Canal are available from 1915 to 1924, as are miscellaneous discharge measurements throughout the 1980s. Measurements of September flow average about $25 \mathrm{ft}^{3} / \mathrm{s}$. Accounting for this ungaged diversion increases the average ground-water discharge in this area based on gage data to $331 \mathrm{ft}^{3} / \mathrm{s}$. This figure compares favorably with the $350 \mathrm{ft}^{3} / \mathrm{s}$ estimate based on synoptic and miscellaneous flow measurements. The temporal variations generally correspond to decadal precipitation cycles (fig. 12), and comparing the calculated September mean groundwater discharge and the cumulative departure from average precipitation at Crater Lake results in a correlation coefficient of about 0.68 .

\section{Upper Klamath Lake Subbasin-Geographic Distribution of Ground-Water Discharge}

The Upper Klamath Lake subbasin encompasses 723 $\mathrm{mi}^{2}$ above the outlet of Upper Klamath Lake, excluding the Williamson and Sprague drainages. The subbasin includes Upper Klamath Lake, the broad, flat Wood River valley to the north and the adjacent uplands including the Cascade Range to the west, Mt. Mazama (the Crater Lake highlands) to the north, and multiple fault-block mountains and the Williamson River delta to the east. The uplands on the eastern side rise abruptly from the valley floor along northsouth trending faults. The Wood River Valley is filled with Quaternary sediment, much of which is fine-grained and has low permeability. Major hydrologic features include the Wood River, Upper Klamath and Agency Lakes, and Sevenmile Creek. 


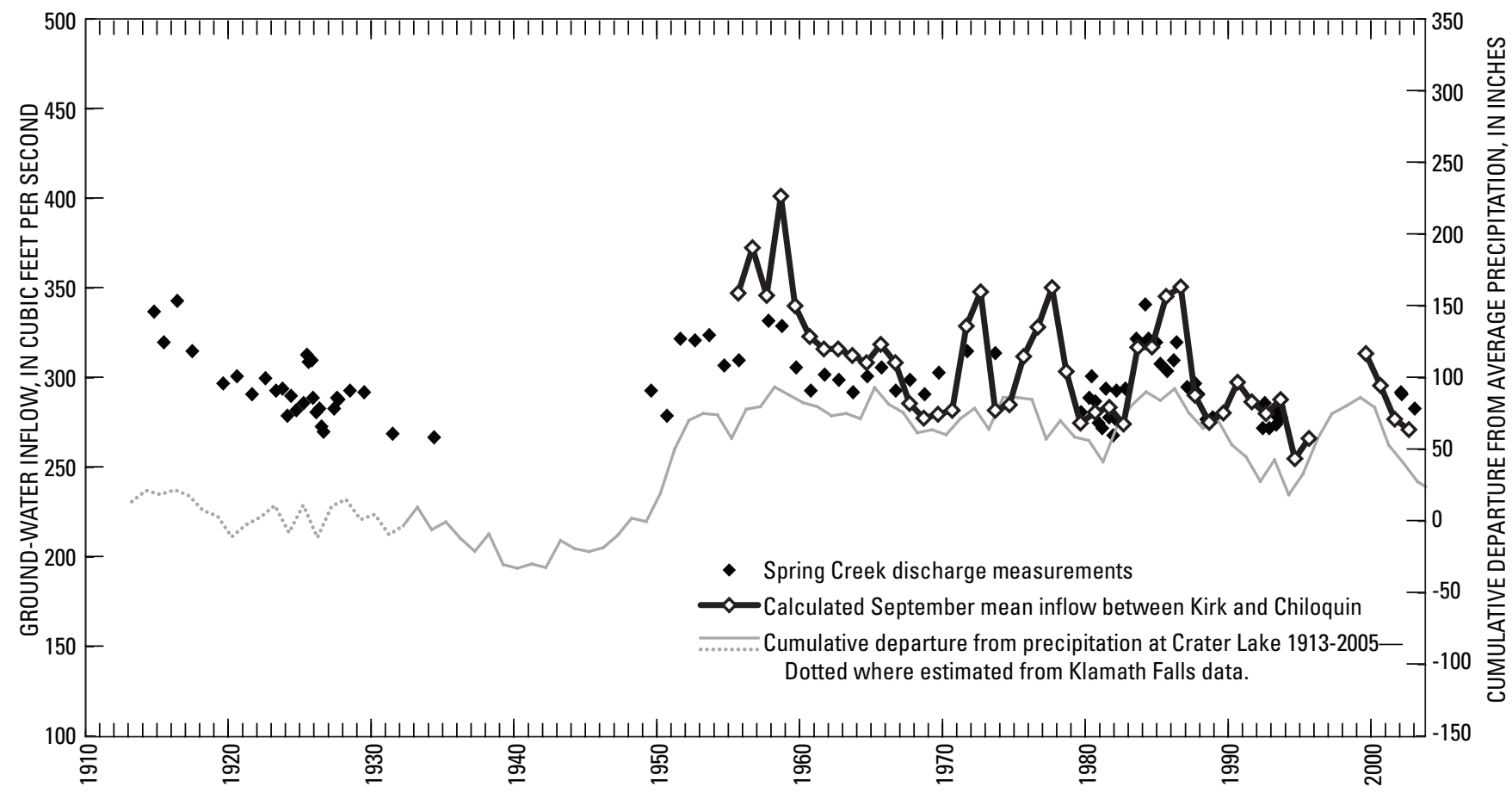

Figure 12. Discharge measurements of Spring Creek, estimated ground-water discharge to the lower Williamson River between Kirk and Chiloquin, and cumulative departure from average precipitation at Crater Lake, Oregon. (Spring Creek measurements from Hubbard and others, 1993, 1994; U.S. Geological Survey, various dates; and USGS and OWRD unpub. data; ground-water discharge estimated as the difference between the flow of the Williamson River below the Sprague River [gaging station 11502500] and the sum of flows of the Williamson River near Kirk [11493500] and the Sprague River near Chiloquin [11501000].)

The general hydrology of the subbasin is dominated by ground-water discharge from spring complexes coincident with fault scarps at the western and eastern edges of the Wood River Valley and Upper Klamath Lake (fig. 7). About one-half of the ground-water discharge in the subbasin occurs to the Wood River and its tributaries (table 6). Approximately onethird of the discharge occurs directly into Upper Klamath Lake at known and unknown locations. The remaining ground-water discharge occurs in the tributaries draining the eastern flank of the Cascade Range.

The Wood River receives the largest amount of ground water in the Upper Klamath Lake subbasin $\left(490 \mathrm{ft}^{3} / \mathrm{s}\right)$, with most of the discharge occurring at discrete spring complexes along the fault scarp on the eastern boundary of the valley (table 6). Two tributaries originating on the flanks of the Crater Lake highland, Annie and Sun Creeks, contribute roughly 14 percent of ground water discharged into the river. The estimates were derived from miscellaneous measurements taken in the Wood River subbasin, with subsequent regressions to index gages.

Ground water discharges from the Cascade Range to tributaries along the western margin of the subbasin at a rate of about $120 \mathrm{ft}^{3} / \mathrm{s}$ (table 6 ). The majority of that flow originates from tributary springs in the valley along the western fault scarp of the region. The creek with the largest watershed in this subarea, Fourmile Creek south of Pelican Butte, contributes only $2 \mathrm{ft}^{3} / \mathrm{s}$ of baseflow to the region. Estimates were derived from short-term gaging station records and regression to index stations elsewhere in the basin.

Ground-water inflow to Upper Klamath Lake was estimated using a monthly water balance for the 1965 through 1967 water years. Hubbard (1970) measured or calculated all tributary inflows and outflows from the lake, including streamflow, diversions, precipitation, evapotranspiration, and agricultural return flows. Hubbard's monthly estimates of ground-water inflow to the lake of averaged about $350 \mathrm{ft}^{3} / \mathrm{s}$ from 1965 to 1967 (the median value is about $330 \mathrm{ft}^{3} / \mathrm{s}$ ). This is about 15 percent of the $2,330 \mathrm{ft}^{3} / \mathrm{s}$ average total inflow to the lake during that period. Hubbard's estimated ground-water discharge to the lake compares favorably with estimates of the difference between Upper Klamath Lake inflows and outflows (such as, ground-water inflow) by others such as Cooper (2004) that cover a much longer base period (30 years compared to 3 years). Hubbard's estimate of average groundwater inflow was revised downward to about $320 \mathrm{ft}^{3} / \mathrm{s}$ by the Bureau of Reclamation (2005) using updated stage-capacity curves for the lake. Although many springs have been mapped around the margins of Upper Klamath Lake, their combined discharge is much less than the estimated ground-water inflow. Consequently, the spatial distribution of much of the groundwater inflow directly to the lake is unknown. 


\section{Upper Klamath Lake Subbasin-Temporal Variations in Ground-Water Discharge}

Temporal variations in ground-water discharge to Annie Spring can be evaluated using data from the gaging station (11503000) that has been operated on Annie Creek just below the spring since 1977 (fig. 13). The discharge from Annie Spring is small, averaging about $3 \mathrm{ft}^{3} / \mathrm{s}$. It is included here to illustrate the behavior of smaller flow systems. Annie Spring shows temporal variations that are different from those of the large-scale systems discussed previously. The lowest flows of large-scale spring systems are typically August through September. The lowest flows of Annie Creek, in contrast, are January through March. The likely cause is that Annie Spring is fed by ground water recently recharged and following very short flow paths, and consequently much of the water feeding the springs is frozen as snow during the winter months. The annual low flows of large-scale systems typically increase each year during periods of successive wetter-than-average years. This is less pronounced with Annie Creek. A graph of monthly and January to March mean flows of Annie Spring (fig. 13) shows that it peaks before the cumulative departure from average precipitation curve. This is because of the lack of storage effects in the small flow system. Annie Spring and similar small-scale flow systems in the upper Klamath Basin have the characteristics of runoff-dominated streams.
Gaging stations have been operated intermittently on the Wood River since 1913. However, data are not easily compared because the stations have been operated at different locations that are affected differently by tributary inflow, return flow, and diversion, and the periods of record are short, ranging from roughly 1 to 14 years. Although the gaging station data do not provide a continuous long-term record of ground-water discharge, they do provide useful information on the magnitude and timing of ground-water discharge fluctuations. A USGS gaging station at Fort Klamath (11504000) operated intermittently from 1913 to 1936 shows a probable drought-related decrease in annual mean flow from approximately 310 to $140 \mathrm{ft}^{3} / \mathrm{s}$ during its period of operation (fig. 14). Another USGS gaging station operated 4 mi south of Fort Klamath (11504100) from 1965 to 1967 shows a climate-related decrease in annual mean flow from 350 to $290 \mathrm{ft}^{3} / \mathrm{s}$ during that period. A gaging station was operated in the early 1990s, and recently near the headwaters springs of the Wood River (about 1 mile downstream at Dixon Road) by Graham Matthews and Associates (GMA). Variations in ground-water discharge to the Wood River headwater springs can be evaluated using the GMA data (provided by Graham Matthews, written commun., May 13, 2003) along with a multitude of miscellaneous instantaneous discharge measurements made over several decades by USGS and OWRD (fig. 14). The measurements near the headwaters

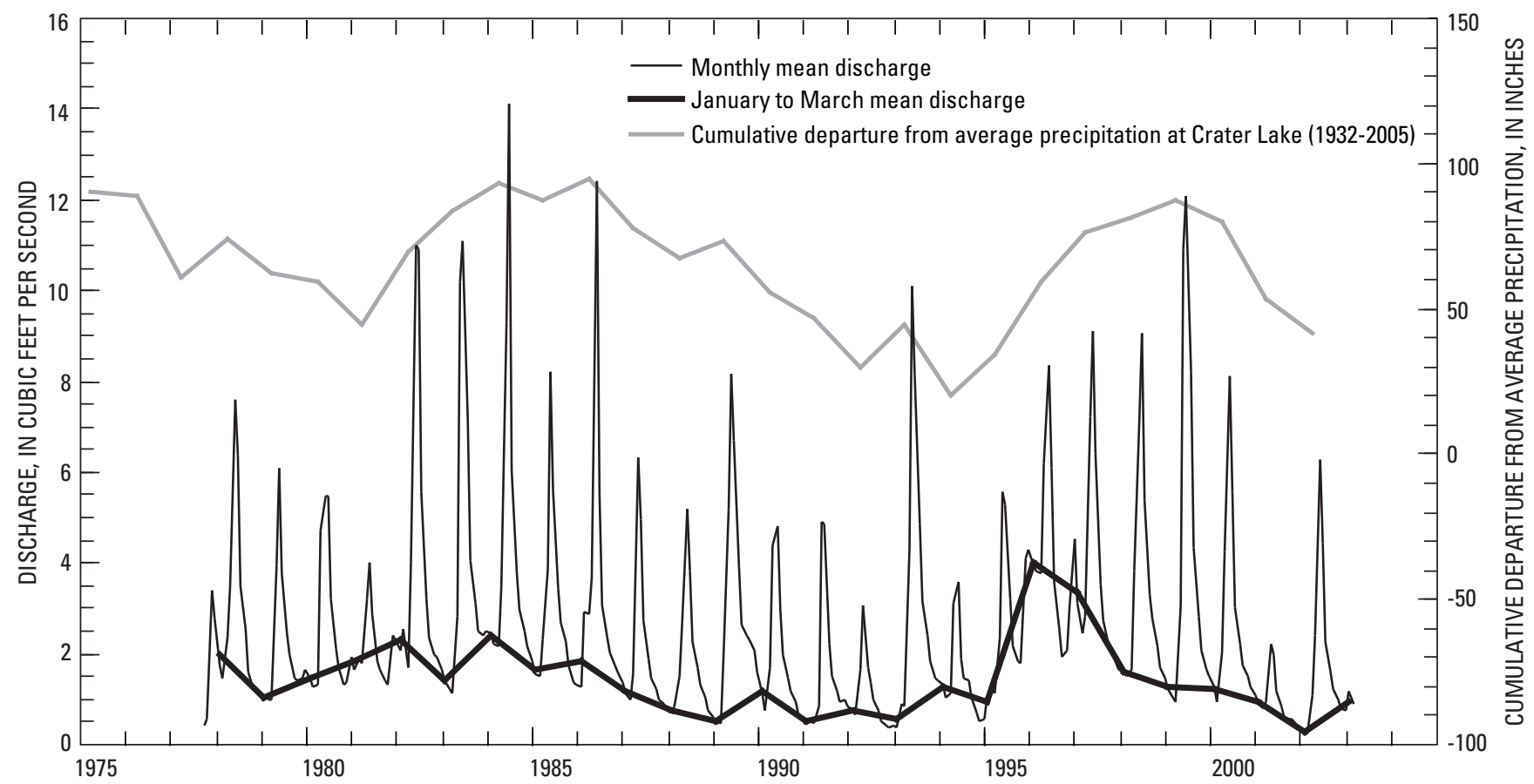

Figure 13. Monthly mean discharge and January to March mean discharge of Annie Spring near Crater Lake, Oregon (USGS gaging station number 11503000), and the cumulative departure from average precipitation at Crater Lake. 


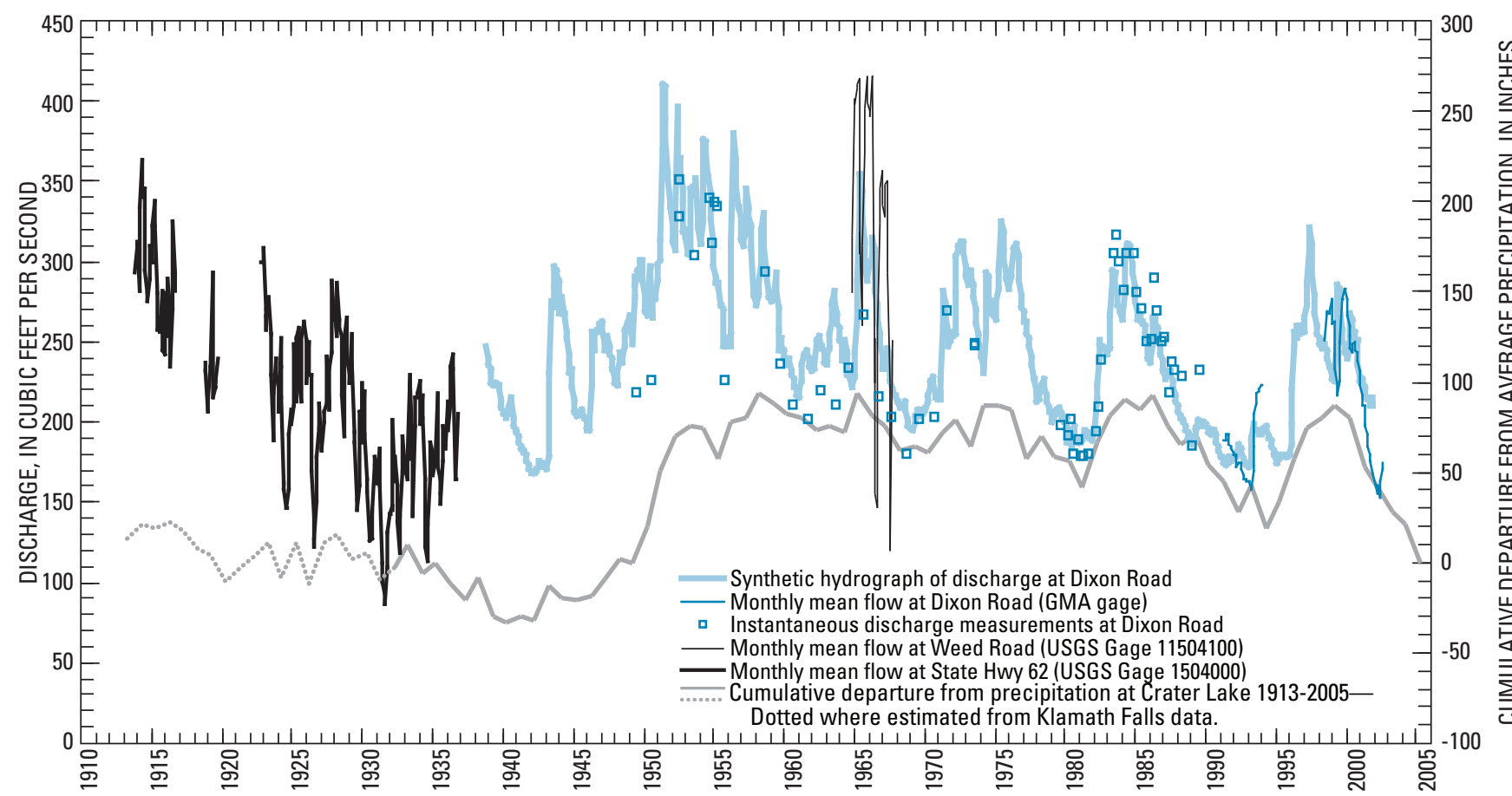

Figure 14. Discharge of the Wood River as measured or estimated at various sites, and the cumulative departure from average precipitation at Crater Lake, Oregon. (Monthly mean flow near headwaters from Graham Matthews, GMA, written commun. May 13, 2003; flow measurements near headwaters from USGS, various dates, and OWRD unpub. data; estimated discharge at Dixon road derived from regression with Fall River in upper Deschutes Basin [USGS gaging station 14057500], a similar size spring-fed stream.)

springs are largely unaffected by tributary inflow and diversions, and are not noticeably influenced by the presently small amount of ground-water pumping in the area. Variations in ground-water discharge to the Wood River headwater springs correlate well with the cumulative departure from average precipitation at Crater Lake $(r=0.75)$. Measurements show the discharge of Wood River near the headwaters springs increasing from 180 to $320 \mathrm{ft}^{3} / \mathrm{s}$ during wet conditions in the early 1980s, and then decreasing from 320 to $160 \mathrm{ft}^{3} / \mathrm{s}$ owing to drought in the late 1980 s and early 1990s. This reduction in ground-water discharge to this single spring complex applied over 1 year equates to 114,000 acre-ft of water.

A synthetic hydrograph of the Wood River near the headwaters springs can be created by using the relation between Wood River discharge measurements and concurrent daily mean flows from the gaging station on Fall River (14057500), a similar-scale spring-fed stream about $70 \mathrm{mi}$ north in the Deschutes Basin (fig. 14). The relation can be modeled using a second order polynomial with an $R^{2}$ of 0.80 . This synthetic hydrograph provides a reasonable depiction of the continuous temporal variations in the discharge of the Wood River headwaters springs.
Temporal variations in ground-water discharge directly to Upper Klamath Lake have not been measured. Given the magnitude of the inflow ( 320 to $350 \mathrm{ft}^{3} / \mathrm{s}$ ), temporal variations can be inferred from other springs in the area with comparable discharge rates and flow-path lengths (such as Wood River Springs).

\section{Lost River Subbasin—Geographic Distribution of Ground-Water Discharge}

The Lost River subbasin occupies about 1,650 $\mathrm{mi}^{2}$ southeast of Upper Klamath Lake. In its natural state, the Lost River subbasin had no outlet and it drained internally. Water occasionally flowed to the subbasin, however, from the Klamath River during floods through a slough connecting the two drainages south of Klamath Falls (La Rue, 1922). With the development of Reclamation's Klamath Project and the construction of the Lost River diversion dam and channel (fig. 3), controlled flow between the Klamath and Lost Rivers in both directions now occurs. Major hydrologic features in this subbasin include Clear Lake and Gerber Reservoirs in the uplands, the Lost River, and the Tule Lake Sump. 
The Lost River proper originates at the outlet of Clear Lake Reservoir in the southeastern part of the basin. From there the river flows northwest, dropping from the plateau containing Clear Lake into the Langell Valley where the river flows to the town of Bonanza. From there it flows west into Poe Valley and subsequently through Olene Gap into the Klamath Valley before turning southeast and terminating in the Tule Lake Sump in California.

The hydrology of the Lost River subbasin is runoff dominated above Clear Lake and Gerber Reservoirs. The drainage area of Clear Lake consists of a broad, low relief, volcanic plateau with a mean altitude of roughly 5,000 ft covering more than $750 \mathrm{mi}^{2}$ south and east of the lake. Only one perennial stream, Willow Creek, exists in the plateau. Values for monthly mean inflows to Clear Lake (calculated from a mass balance) show that high flows occur in March $\left(500 \mathrm{ft}^{3} / \mathrm{s}\right)$, whereas low flows occur in late summer $\left(30 \mathrm{ft}^{3} / \mathrm{s}\right)$. The lands draining to Gerber Reservoir are more mountainous than those draining to Clear Lake, but are geologically similar. Mean monthly inflows to Gerber Reservoir are highest in March $\left(280 \mathrm{ft}^{3} / \mathrm{s}\right)$ and lowest during the late summer (4-5 $\mathrm{ft}^{3} / \mathrm{s}$ ). Water from Gerber Reservoir flows to the Lost River via Miller Creek.

Several springs contribute flow to the Lost River subbasin in the sediment filled Langell, Yonna, and Poe valleys. Bonanza Spring, near the town of Bonanza, is a major contributor of baseflow to the river as are a series of springs adjacent to the river near Olene Gap.

Little historical data are available with which to estimate ground-water discharge in most of the Lost River subbasin. For Clear Lake and Gerber Reservoirs, USGS streamgaging data collected prior to the construction of the reservoirs were used along with inflows reported by Reclamation (Bureau of Reclamation, 1954, Appendix B) to estimate ground-water discharge during fall. The average discharge during the period of record was $40 \mathrm{ft}^{3} / \mathrm{s}$ and $10 \mathrm{ft}^{3} / \mathrm{s}$, respectively for the two reservoirs. Limited data for the remaining area are available from gages operated intermittently in the early 1900s and late 1990s on the Lost River. Sets of synoptic measurements (Leonard and Harris, 1974; Grondin 2004) were sufficient to determine the location of gains to the river below the reservoirs. These measurements demonstrate that most ground-water discharge into the Lost River proper occurs at two locations: Bonanza Springs and the area just upstream of Olene Gap. The overall gain to the river between Olene and the two reservoirs is about $140 \mathrm{ft}^{3} / \mathrm{s}$, largely on the basis of synoptic measurements. The temporal variability of groundwater inflow is poorly known owing to the short periods of record. Below Olene Gap, data were insufficient to estimate ground-water discharge to the river. Likewise, data were insufficient to estimate direct ground-water discharge to the Tule Lake Sump.

\section{Lost River Subbasin-Temporal Variations in Ground-Water Discharge}

Bonanza Springs is the only location in the Lost River subbasin where data are sufficient to evaluate temporal variations in ground-water discharge. These springs discharge from basalt to the Lost River. Twenty-one discharge measurements of the springs, made by USGS, OWRD, or Reclamation, are in the published and unpublished literature (fig 15). Discharge of the springs is in all cases determined by comparing the difference in streamflow of the Lost River upstream and downstream from the town of Bonanza. Many upstream measurements were made between 2 and $3 \mathrm{mi}$ from Bonanza, and some were made at a bridge about $5 \mathrm{mi}$ upstream. Downstream measurements all have been made about 3 mi downstream at Harpold Dam. Some determinations of spring flow account for all tributary inflows (including agricultural drains) and diversions between the upstream and downstream measurement sites. Other than Bonanza Springs, these gains and losses are minor outside of the irrigation season. Many determinations of spring flow include only the upstream and downstream measurements and measurement of the single major tributary, Buck Creek. Determinations of spring discharge made by comparing flows only at Keller Bridge, Buck Creek, and Harpold Dam outside of the irrigation season are considered reasonable because the spring discharge is much larger than the other stream gains and losses.

Discharge measurements of Bonanza Springs show considerable temporal variation (fig. 15). The largest measurement, $118 \mathrm{ft}^{3} / \mathrm{s}$ in October 1958, occurred after a 15 -year period of wetter-than-average weather. The smallest measurement, $38 \mathrm{ft}^{3} / \mathrm{s}$ in January 1992, occurred late in a drought that started in the mid-1980s. Overall, the pattern of spring discharge follows the general pattern of precipitation, reflecting drought cycles and a general drying trend since the late 1950s. Unfortunately, no measurements are available from the very dry period in the early 1940s. Bonanza Springs discharge is affected by climate, ground-water pumping, and artificial manipulation of the stage of the Lost River (Grondin, 2004). Discharge from the main spring can cease entirely during the irrigation season in dry years. Most measurements after 1960 (fig. 15) were made well after the irrigation season (December to April), so the system should have mostly recovered from the seasonal effects of pumping and diversion. Present information is insufficient, however, to determine precisely how much of the variation in spring discharge is natural and how much is related to pumping. 


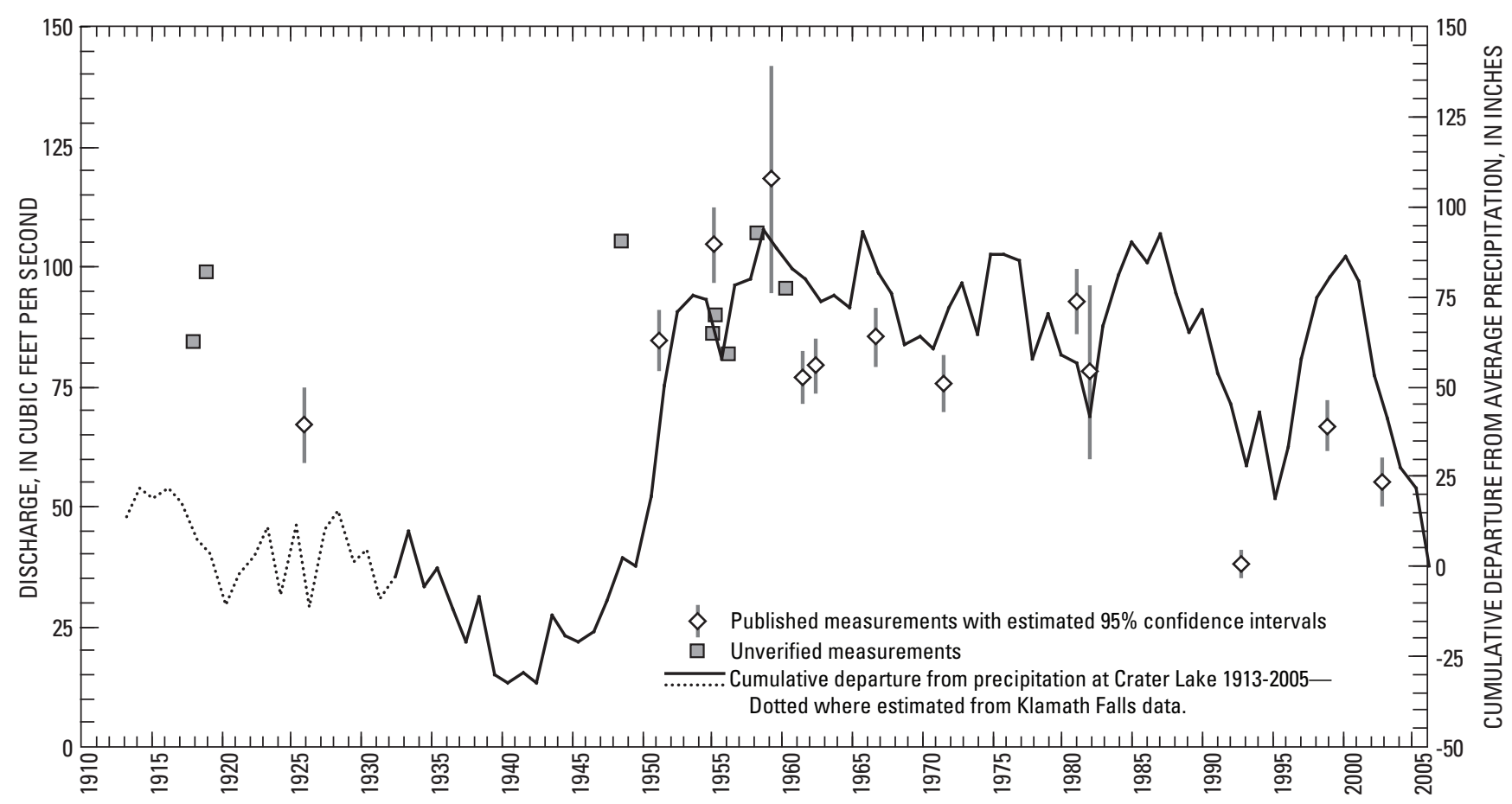

Figure 15. Discharge of Bonanza Springs and cumulative departure from average precipitation at Crater Lake, Oregon. (Sources of data: Meinzer, 1927; U.S. Geological Survey, 1956, 1960a; Leonard and Harris, 1974; Grondin, 2004; measurements labeled unverified appear in official State of Oregon correspondence and are attributed to Reclamation and USGS, but no original records were found.)

\section{Klamath River Subbasin-Geographic Distribution of Ground-Water Discharge}

The Klamath River subbasin encompasses the area between the outlet of Upper Klamath Lake and Iron Gate Dam. The main hydrologic features are John C. Boyle, Copco, and Iron Gate Reservoirs, Lake Ewauna, Lower Klamath Lake, and the Klamath River. The Klamath River begins at the outlet of Upper Klamath Lake, where, for the first mile or so, it is known as the Link River. From the dam, the Link River flows about $1 \mathrm{mi}$ through a narrow gorge into a broad, flat valley containing Lake Ewauna, the head of Klamath River proper. Lake Ewauna, impounded by Keno Dam, is a long, narrow reservoir that traverses the northern part of the Lower Klamath Lake subbasin.

Prior to development of the region, the Klamath River occasionally spilled across the low, nearly level divide into the Lost River subbasin during floods. La Rue (1922) hypothesized that water also may have flowed from the Lost River to the Klamath River subbasin during floods. Recent analysis of topographic mapping from the early 1900s, however, suggests that the Lost River was incised to the degree that flow from the Lost River system to the Klamath River subbasin was highly unlikely (Jon Hicks, Bureau of Reclamation, oral commun., 2006). Water also moved between the Klamath River and Lower Klamath Lake subbasin prior to development. Water flowed from the Klamath River into
Lower Klamath Lake during periods of high flow, usually in winter or spring. After high flows, water would flow out of the lake through the Klamath Strait back into the Klamath River. There is some uncertainty as to timing and duration of flow from the lake to the river, and it probably varied from year to year with hydrologic conditions (Weddell, 2000; Bureau of Reclamation, 2005). Flows into and out of the Lost River and Lower Klamath Lake subbasins are now controlled.

Downstream from Lake Ewauna and Keno Dam, the Klamath River enters a canyon and flows into John C. Boyle Reservoir (operated by PacifiCorp), near the confluence with Spencer Creek. Below John C. Boyle Dam, the river drops into another steep canyon. About 1 mile below the dam, a large spring complex contributes significant flow to the river. Numerous perennial streams originating from the High Cascades and older Western Cascades also add flow to the river between Keno and Iron Gate Dams. These tributaries are predominately runoff dominated; however several (for example, Spencer and Fall Creeks) have large components of ground-water discharge. Flows in the Klamath River above Iron Gate Dam are largely regulated by Reclamation and PacifiCorp impoundments, including Link River Dam at the outlet of Upper Klamath Lake. Gaging station data from below Iron Gate Dam (11516530) show a high mean monthly flow of $3,600 \mathrm{ft}^{3} / \mathrm{s}$ in March and a low mean monthly flow of $770 \mathrm{ft}^{3} / \mathrm{s}$ in August. 
Most ground-water discharge in this subbasin occurs along the Klamath River and principal tributaries. A small amount of ground water also discharges to springs southwest of Lower Klamath Lake. Ground-water discharge in the Klamath River subbasin was calculated directly from longterm streamflow data and corrected for reservoir storage in reaches of the Klamath River from the gaging station at Keno (11509500) to the gaging station below the John C. Boyle Power Plant (11510700) (about $5 \mathrm{mi}$ below the dam), and from that gage to the gage below Iron Gate Dam (11516530). Some short-term streamflow records available for tributaries were useful for discriminating ground-water discharge directly to the river from discharge to tributaries. Gains and losses between Link River Dam and Keno were not estimated owing to large uncertainties in the data in that reach. Discharge to springs southwest of Lower Klamath Lake was not measured for this study, but measurements are available from Wood (1960) and Reclamation records.

The largest source of ground-water discharge between the gage at Keno and the gage below the John C. Boyle Power Plant is a series of springs about a mile below the dam (fig. 7 and table 6). Although early references to these springs are scarce, Newcomb and Hart (1958) note that springs contribute "considerable inflow" to the river in this area. Their observations and those of local residents cited in their report predate construction of John C. Boyle Dam, indicating that these springs do not merely represent reservoir seepage. Records show that average gain from the springs is about $190 \mathrm{ft}^{3} / \mathrm{s}$ (table 6). The temporal variation in the discharge of these springs is well characterized. The baseflow of Spencer Creek, tributary to the Klamath River in this reach, is about $27 \mathrm{ft}^{3} / \mathrm{s}$.

Between the gage below the John C. Boyle Power Plant and that below Iron Gate Dam, gains averaged $140 \mathrm{ft}^{3} / \mathrm{s}$ from 1967 to 2000 (table 6). The spatial location of the groundwater discharge in this reach is not well known; however, there is evidence of inflow to the main stem of the Klamath River between river miles 207 and 213, roughly between Shovel and Rock Creeks. Thermal infrared remote sensing shows that the river cools in this reach, an indication of ground-water discharge (Watershed Sciences, 2002). This reach corresponds with the boundary between the High Cascade and Western Cascade subprovinces and is therefore an area of expected ground-water discharge. In addition, the reach traverses a large landslide complex with numerous mapped springs. Some inflow in this reach is due to tributary streams. Fall Creek, which drains an area dominated by rocks of the High Cascade subprovince, is the largest known contributor, with a baseflow of about $36 \mathrm{ft}^{3} / \mathrm{s}$, whereas the much larger Jenny Creek watershed, which is underlain largely by low-permeability older volcanic rocks, contributes only about $9 \mathrm{ft}^{3} / \mathrm{s}$. Flow data are sparse for the remaining tributaries in Oregon, but regional regression techniques show that these contributions probably amount to slightly greater than $1 \mathrm{ft}^{3} / \mathrm{s}$. The component of baseflow to the reach from California tributaries is unknown.

Ground water also discharges to a number of spring complexes southwest of Lower Klamath Lake (fig. 7 and table 6). Reclamation engineer Louis Hall made a reconnaissance of the Lower Klamath Lake subbasin in September 1908 during which he inventoried springs along the margin of the lake and estimated their discharge. His estimates of spring discharge to the lake total $104 \mathrm{ft}^{3} / \mathrm{s}$, although his estimating methods are not known (Tom Perry, Bureau of Reclamation, written commun., 2006). Wood (1960) made several measurements of discharge at three of the principal spring complexes during water year 1955 . $\mathrm{He}$ also reports CDWR observations that year for a fourth discharge measurement. Wood's measurements are not directly comparable to Hall's earlier estimates because of differences in locations; however, in cases where general comparisons can be made, Wood's measured flows appear to be about one-half of Hall's estimates. Averages of Wood's measurements total about $35 \mathrm{ft}^{3} / \mathrm{s}$. Some small seasonal variability is evident in the measurements, but the data are too sparse to define a pattern and identify the source of the variability. Measurements made in 1955 may reasonably represent the average flow during the early 1950s. Precipitation during water year 1955 was less than average, but 1953 and 1954 were close to the long-term average. Discharge of these springs probably is now less than it was in the mid-1950s, owing to dryer conditions in recent decades and increased ground-water development in the area.

\section{Klamath River Subbasin-Temporal Variations in Ground- Water Discharge}

The principal sources of data used to evaluate groundwater discharge variations in the Klamath River subbasin are stream-gaging stations at Keno (11509500), below the John C. Boyle power plant (11510700), and below Iron Gate Dam (11516530). These data are augmented with short-term gaging station records from Spencer and Fall Creeks (11510000 and 11512000 , respectively). Understanding ground-water discharge variations along the Klamath River, however, is complicated by inflow from ungaged tributaries, unmeasured diversions, and changes in reservoir storage.

Ground-water discharges to the Klamath River between the Keno gage and the gage below the John C. Boyle power plant. Nearly all of the discharge is from a spring complex near river mile 224 about 1 mi below the John C. Boyle Dam and about $3.5 \mathrm{mi}$ above the power plant. Thermal infrared remote sensing on July 15, 2002, showed that this spring complex cooled the river about $10^{\circ} \mathrm{F}$ (Watershed Sciences, 2002). Gage data indicate the flow in the river just below the springs was about $370 \mathrm{ft}^{3} / \mathrm{s}$ on that date. Temporal variations 
in net ground-water discharge to this reach can be evaluated by comparing August mean flows at the two gages and accounting for changes in storage of John C. Boyle Reservoir (reservoir data from Rob Allerman, PacifiCorp, written commun, 2002). August means were used to evaluate temporal variations here instead of the September-November means to minimize the effects of fall storms. This can be done because diversions are insignificant and the mean August inflow (240 $\mathrm{ft}^{3} / \mathrm{s}$ ) is reasonably close to the mean September-November inflow $\left(230 \mathrm{ft}^{3} / \mathrm{s}\right)$.

A graph showing the August mean net inflow to the reach between Keno and the gage below the John C. Boyle power plant (fig. 16) shows that ground-water discharge to this reach varied from less than $200 \mathrm{ft}^{3} / \mathrm{s}$ to greater than $300 \mathrm{ft}^{3} / \mathrm{s}$ during the period of record. The average error in the individual inflow estimates is approximately $\pm 50 \mathrm{ft}^{3} / \mathrm{s}$ on the basis of measurement error of the stream gages. The general pattern of ground-water discharge loosely follows the decadal cycles seen in precipitation, with the lowest inflows corresponding to extended periods of drought, but that correlation is low $(r=0.30)$.
Ground-water discharge also occurs to the Klamath River between the gaging station below the John C. Boyle power plant and the gaging station below Iron Gate Dam. Evaluating temporal variations in ground-water discharge to this reach is made difficult by ungaged tributary inflow and probable diversions. Moreover, calculated inflow values include cumulative errors in data from the two gaging stations and in storage measurements of two large reservoirs. As with the upstream reach, temporal variations in ground-water discharge can be evaluated by calculating the differences between flows at the two gages and accounting for changes in reservoir storage (fig. 16). September to November mean inflows are used here to minimize the effects of diversions.

Between 1967 and 2002, the September to November mean inflow between the gaging stations below the John C. Boyle power plant and Iron Gate Dam ranged from 30 to 330 $\mathrm{ft}^{3} / \mathrm{s}$, averaging $140 \mathrm{ft}^{3} / \mathrm{s}$ (fig. 17). About $45 \mathrm{ft}^{3} / \mathrm{s}$ if this inflow is from Fall and Jenny Creeks (table 6). The uncertainty of the inflow estimates due to measurement error is $\pm 110 \mathrm{ft}^{3} / \mathrm{s}$. The correlation between ground-water discharge and climate is not as apparent here as elsewhere in the basin owing to the small amount of net ground-water inflow relative to the streamflow measurement error.

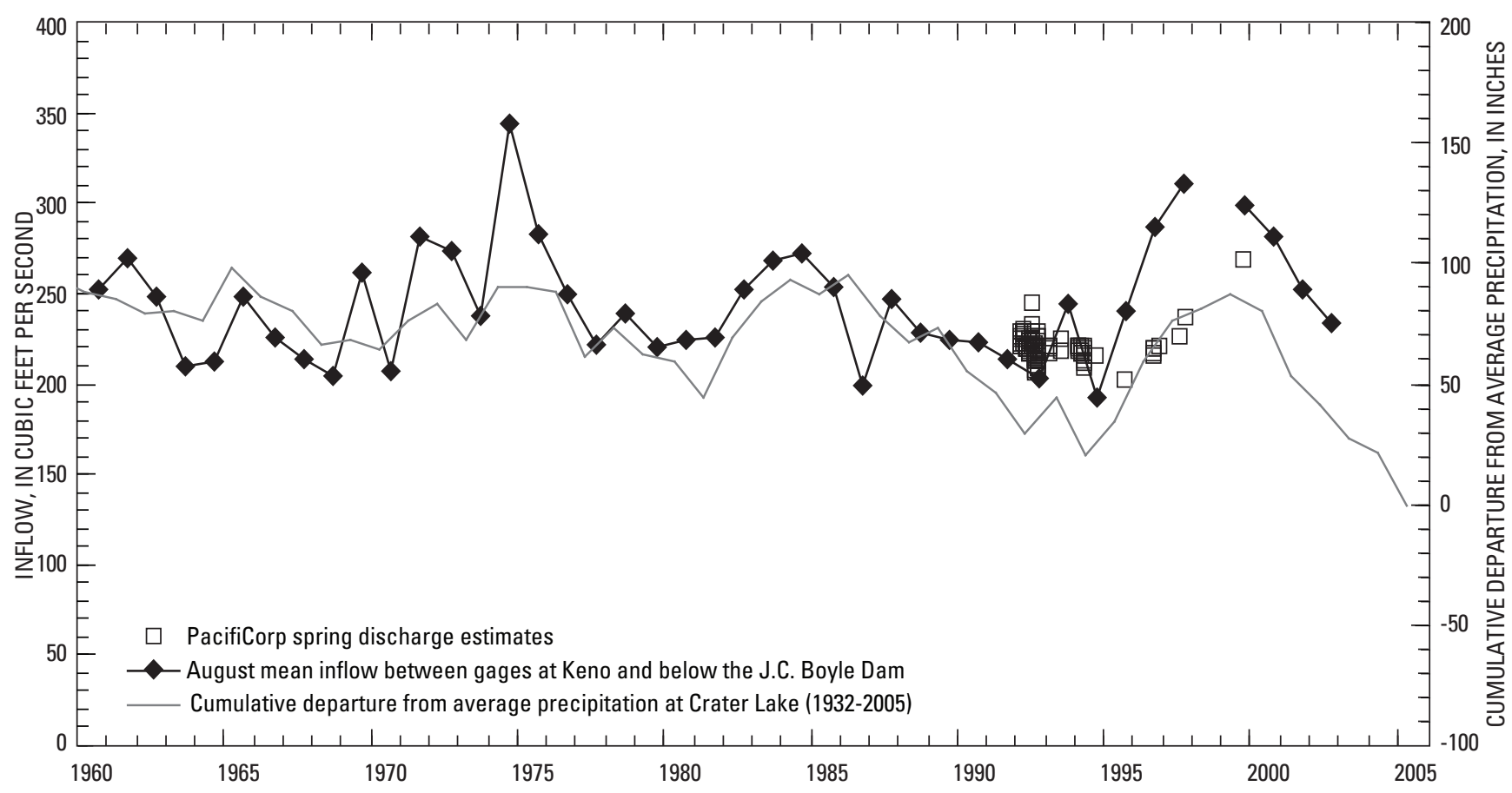

Figure 16. August mean gains in flow (a proxy for ground-water discharge) between Keno (USGS gaging station number $11509500)$ and the John C. Boyle power plant (11510700), estimates of inflow by PacifiCorp, and the cumulative departure from average precipitation at Crater Lake, Oregon. (PacifiCorp data from Rob Allerman, written commun., 2002). 


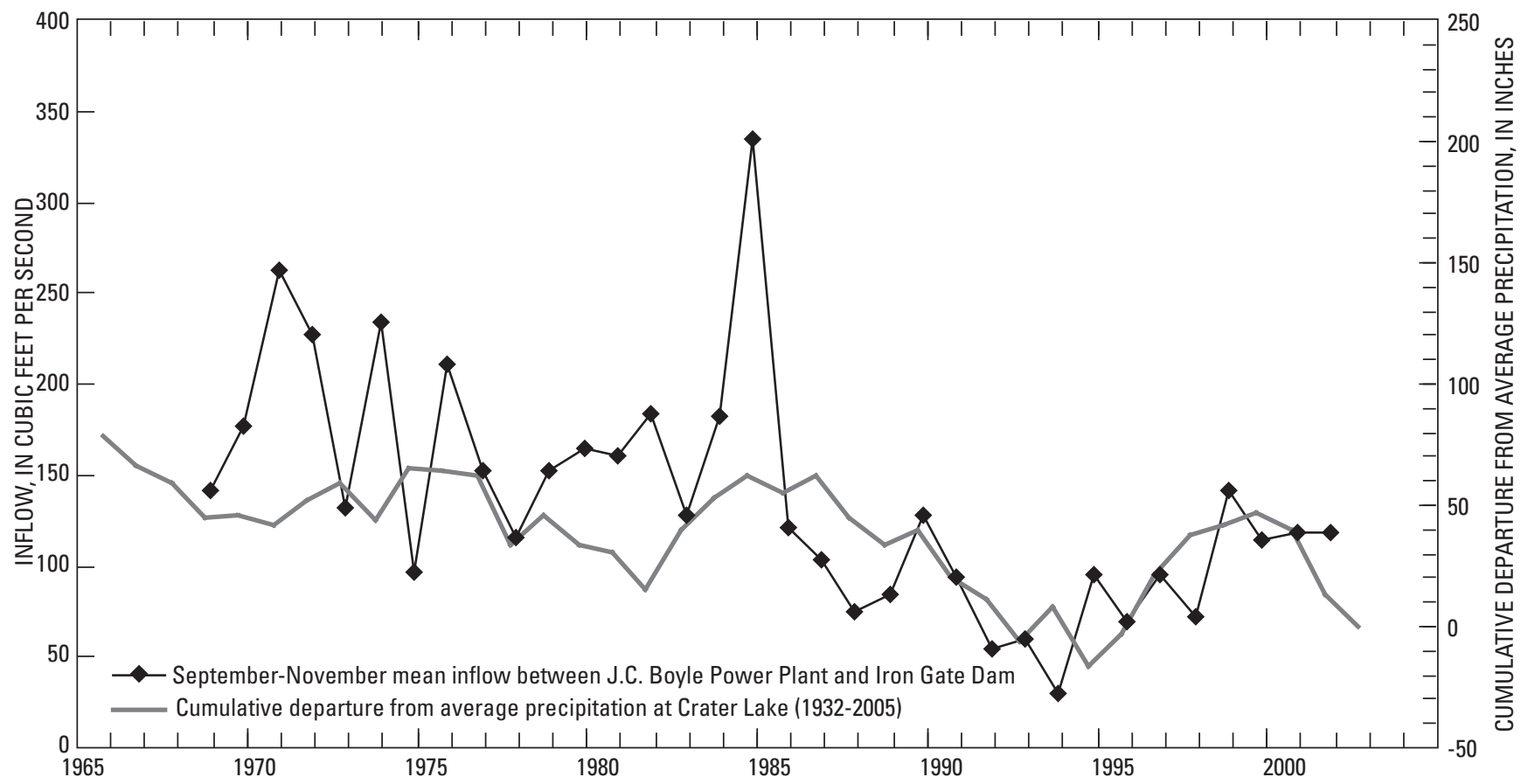

Figure 17. September to November mean gains in flow (a proxy for ground-water discharge) between the John C. Boyle power plant (USGS station number 11510700) and Iron Gate Dam (11516530), and the cumulative departure from average precipitation at Crater Lake, Oregon.

\section{Summary of Geographic and Temporal Variations of Ground-Water Discharge to Streams}

Analysis of streamflow data indicates that many streams in the upper Klamath Basin have a large component of ground water. Most streams throughout the world rely on groundwater discharge to support flows during the dry season. The upper Klamath Basin and other basins on the eastern flank of the Cascade Range are unique in that ground water discharge composes a large proportion of the total streamflow. This is attributable to the substantial regional ground-water system that exists in the permeable volcanic terrane. Some major streams in the basin, such as the Wood River and Spring Creek, are virtually entirely ground water fed. It has long been recognized that much of the water flowing into Upper Klamath Lake originates as ground-water discharge (Bureau of Reclamation, 1954, p. 150). Of the 2,200-2,300 $\mathrm{ft}^{3} / \mathrm{s}$ average total inflow to the lake (from Hubbard, 1970, and Reclamation records), at least 60 percent can be attributed to ground-water discharge in the Wood River subbasin and springs in the lower Sprague River drainage and the Williamson River drainage below Kirk. This quantity does not include ground-water discharge to upper parts of the Williamson and Sprague River systems, which would make the figure even larger. The large component of ground water in streamflow influences the hydrologic response of the basin to climate cycles, and has implications for flow forecasting (Risley and others, 2005).
Discharge from all major ground-water discharge areas in the basin fluctuates over time. Ground-water discharge fluctuations are primarily climate driven, and, therefore, discharge from the various sources tends to vary in unison. Owing to the effects of ground-water storage, regional-scale discharge areas integrate climate conditions over multiple years. Consequently, ground-water discharge fluctuations tend to follow a pattern similar to the cumulative departure from average precipitation. A practical implication of this observation is that ground-water discharge from storage may support robust streamflow during a dry year following a series of wet years. Conversely, it may take multiple years of average or above average conditions following a protracted drought to replace ground-water storage and return spring discharge (and hence, streamflow) to predrought conditions.

Ground-water discharge variations can represent substantial volumes of water on an annual basis. The combined ground-water discharge to the lower Williamson, Sprague, and Wood Rivers just upstream of Upper Klamath Lake can vary by at least $450 \mathrm{ft}^{3} / \mathrm{s}$ in response to climate cycles. This equates to an annual volume of 326,000 acre$\mathrm{ft}$. The actual variation in ground-water discharge to Upper Klamath Lake and its tributaries is larger, because the probable variations in ground-water discharge to Fort Creek, Crooked Creek, and springs discharging directly to the lake have not been included. Gaging station data show that net ground-water inflow to the Klamath River (and ground-water fed tributaries) between Keno and Iron Gate Dam probably varies at least 150 $\mathrm{ft}^{3} / \mathrm{s}$ in response to climate. 


\section{Ground-Water Discharge to Wells}

Ground water pumped from wells in the upper Klamath Basin is used primarily for public supply and agriculture. For public supply, ground water is provided by public or privately owned utilities for drinking, municipal, industrial, and commercial purposes. Most ground water pumped for irrigation is used for agriculture; however, some is used for irrigation of cemeteries, parks, and golf courses. The following discussion is limited to ground-water withdrawals for publicsupply and agricultural irrigation. Industrial and domestic withdrawals from individual private wells are not discussed because their proportion of the total ground-water use in the basin is small.

\section{Methods}

Ground-water pumping for public-supply and irrigation was estimated using different methods. Since 1985, OWRD has required public suppliers to report ground-water pumpage annually. Public suppliers in Oregon report monthly pumpage totals by individual well for each water year. The totals typically are based on direct flowmeter measurements or calculated from pumping rates and duration of pumping. The totals for this report were based on reported pumpage in 2000 . No pumpage data were available for the small California communities of Dorris, Macdoel, and Tulelake. Groundwater withdrawals for these suppliers were estimated using population data.

Neither Oregon nor California requires well owners to report ground-water withdrawals for irrigation. Some irrigators in Oregon report their yearly pumpage to OWRD either voluntarily or as required by conditions in their waterright permit, but such reporting is rare. The lack of any comprehensive reporting system by both States means that indirect methods based on water right information, satellite imagery, and land and water surveys must be used to estimate the rate and distribution of ground-water withdrawal.

\section{Ground-Water Pumpage for Public-Supply Use}

Ground water is the source of water supplied by eight public systems and one quasi-public system in the study area. Public suppliers of ground water include the communities of Klamath Falls, Bly, Chiloquin, Merrill, and Malin. One resort community northwest of Klamath Falls is considered a quasimunicipal system on the basis of the variety of water uses. Ground-water withdrawals for the communities of Dorris, Macdoel, and Tulelake were estimated using recent population totals and a per capita use of 150 gallons per day (according to the methods of Broad and Collins, 1996). Public-supply systems that served more than 25 people or had at least 15 connections pumped approximately $9.3 \mathrm{Mgal} / \mathrm{d}$ (million gallons per day) or about $14.4 \mathrm{ft}^{3} / \mathrm{s}$ in 2000 . By comparison, in the 5-year period from 1996 through 2000, public supply withdrawals in the basin averaged an estimated $8.2 \mathrm{Mgal} / \mathrm{d}$ $\left(12.7 \mathrm{ft}^{3} / \mathrm{s}\right)$. The City of Klamath Falls, with a population of 19,400 , accounted for 84 percent of the 2000 total, reporting withdrawals of $7.8 \mathrm{Mgal} / \mathrm{d}(12.1 \mathrm{ft} / \mathrm{s})$ from 9 city wells. Per capita use in cities such as Klamath Falls is larger than in rural areas and small towns due to the larger relative amount of commercial, industrial, and irrigation included.

\section{Ground-Water Pumping for Irrigation}

In Oregon, ground-water pumpage for irrigation was estimated by matching maps of primary and supplemental irrigation ground-water rights to areas that were determined to be irrigated by using a land-cover data set created from 30-meter resolution Landsat satellite imagery taken during the 2000 irrigation season. The Landsat image data were analyzed to help identify vegetation types and conditions (such as the stage of growth) in a process known as "classification." The ground-water rights data sets consisted of geographic information system (GIS) layers showing places of use (POUs) and points of appropriation (POAs), and were provided by the OWRD along with data from their Water Rights Information System. The POUs represent the fields where water is applied under the terms of the water right. That right might be a primary right for ground-water irrigation, or a supplemental right under which ground water is used to supplement a primary surface-water right on the same land. A water-right can cover a single tract or several tracts not necessarily adjacent to one another. POAs correspond to specific wells at particular locations on ground-water rights. A single ground-water right may include more than one well. Pumpage was estimated only for active primary and supplemental ground-water rights for irrigation outside of irrigation district boundaries. It was assumed that no primary ground-water rights are in areas included in irrigation districts within the Klamath Project, and that supplemental groundwater irrigation within irrigation districts was negligible in 2000.

The POU boundaries were overlaid with the lands determined to be irrigated using the classified Landsat imagery (fig. 18). The purpose of the overlay was to match specific water rights to irrigated areas shown on the land-cover map developed from the imagery. The results reveal which fields with ground-water rights were actually irrigated during the 2000 irrigation season. Partial overlay matches, where either the irrigated lands from the imagery did not completely fill a POU field boundary or the imagery showed many small blocks of irrigated areas within a field boundary, were evaluated individually and the acres included or dropped (considered irrigated or not irrigated) on the basis of specific criteria. Any irrigated fields smaller than 3 acres were eliminated. Ground-water pumpage used in irrigated areas was assigned to a specific well based on water right information. Where the land-cover data showed an obvious irrigated field (for 
example, from a center pivot) but no matching water right in the GIS data set, a withdrawal location based on the centroid of the field was used. In total, 19,250 acres of cropland in the upper Klamath Basin in Oregon was estimated to have been irrigated with ground water in 2000 , or about 30 percent of the 64,000 acres with Oregon primary ground-water rights evaluated in this analysis.

The estimation method produced a conservative number of irrigated acres and points of appropriation. The apparent low percentage of ground-water rights exercised in 2000 may be attributable to counting only the acres appearing to be irrigated on Landsat images rather than the total acreage carried on the water right, and editing criteria that were more likely to eliminate than include fields where evidence of irrigation was questionable on the satellite image. Any irrigation in areas not included in the OWRD digital water right POU maps is not included in the estimate. Estimates of pumpage within irrigation district boundaries under a pilot water bank and similar programs starting in 2001 are discussed in a separate section

The crop types in areas irrigated with ground water in Oregon were determined from the classified Landsat satellite imagery using the methodology described in appendix A. Specific crop types could not be reliably identified using the Landsat imagery. Five vegetative classes of crop types were identified, however, on the basis of spectral signatures and potential water requirements. The five classes are (1) alfalfa and irrigated grasses, (2) small grains, (3) onions and garlic, (4) potatoes and corn, and (5) strawberries.

About 40,000 acres were irrigated with ground water in the upper Klamath Basin in California during 2000. California water law does not require a permit or approval to withdraw ground water from wells (California State Water Resources Control Board, 1990). The estimation of ground-water withdrawals in this report relied primarily on data compiled from a comprehensive land and water survey by the CDWR's Northern District in summer 2000 for the State water plan update (Todd Hillaire, CWDR, written commun., April, 28, 2003). For each tract of land surveyed, CDWR determined the source of water, crop type and in most instances, the type of irrigation system used. The estimate in this report includes only those lands assessed through the survey as entirely or partially irrigated with ground water.

Irrigation water use on individual parcels was estimated based on the crop type, acreage, crop-water requirements, and irrigation method used. Alfalfa, pasture, grains, potatoes, onions, and garlic represented the predominant crop types, but mint, sunflowers, strawberries, and sugar beets also were grown. Crop-water requirements were derived using published data (Cuenca and others, 1992), evapotranspiration (ET) totals recorded at Bureau of Reclamation Agrimet sites in Klamath Falls and Worden, and information provided by State and county agricultural agencies. The irrigation seasons for certain crop types were determined from Agrimet data, interviews with county and State agricultural agencies, and from published crop reports by the U.S. Department of Agriculture (2004). Sprinkler application efficiency rates were not field measured but obtained from published sources, including King and others (1978) and from communication with State agricultural agents. Efficiencies assigned ranged from 45 percent for gravity systems, to 75 percent for most center pivots, to 90 percent for drip systems. Most groundwater irrigation was done using sprinkler systems. The average application efficiency was estimated to be about 72 percent. Withdrawals were computed by dividing the crop-water requirements by the irrigation method efficiency.

On lands with primary surface-water rights (outside of irrigation districts) and supplemental ground-water rights, the wells were assumed to have been used and were assigned 50 percent of the computed total irrigation requirement. About 620 acres with supplemental ground-water rights outside of irrigation districts were estimated to have been irrigated in 2000. This estimate may be conservative for reasons previously listed.

During the 2000 irrigation season, an estimated 150,000 acre-ft of ground water was pumped to irrigate about 59,600 acres (table 4 and fig. 18). In Oregon, 19,200 acres were irrigated with ground water (about 32 percent of the total), and 40,400 acres (68 percent of the total) were irrigated with ground water in California. Withdrawals in the Butte Valley were about 75,600 acre-ft, or 50 percent of the total in the upper Klamath Basin. All withdrawals for this subbasin were in California. Pumpage in the upper Lost River subbasin, which includes Swan Lake, Langell, Yonna, and Poe Valleys in Oregon, totaled about 28,800 acre-ft, or 19 percent of the total withdrawals. All irrigated acres for this subbasin were in Oregon. In the Sprague River Basin, approximately 11,600 acre-ft of water was pumped, about 8 percent of the total pumpage in the study area. Pumpage in the lower Lost River and Lower Klamath Lake subbasin, which span both States, totaled about 28,600 acre-ft, or about 19 percent of the total pumpage. Ground-water pumpage for irrigation in the Wood River subbasin totaled only about 1,100 acre-ft.

Table 4. Estimated ground-water pumping for irrigation in the upper Klamath Basin, Oregon and California, during water year 2000.

\begin{tabular}{lcc}
\hline \multicolumn{1}{c}{ Subbasin } & $\begin{array}{c}\text { Area irrigated } \\
\text { with ground water } \\
\text { (acres) }\end{array}$ & $\begin{array}{c}\text { Estimated } \\
\text { pumpage } \\
\text { (acre-feet) }\end{array}$ \\
\hline Upper Williamson River & 2,100 & 4,600 \\
Sprague River & 4,300 & 11,600 \\
Wood River & 360 & 1,100 \\
Upper Lost River & 10,500 & 28,800 \\
Lower Lost River & 4,700 & 11,500 \\
Lower Klamath Lake & 5,600 & 17,100 \\
Butte Valley & 32,000 & 75,600 \\
Total (rounded) & 59,600 & 150,000 \\
\hline
\end{tabular}




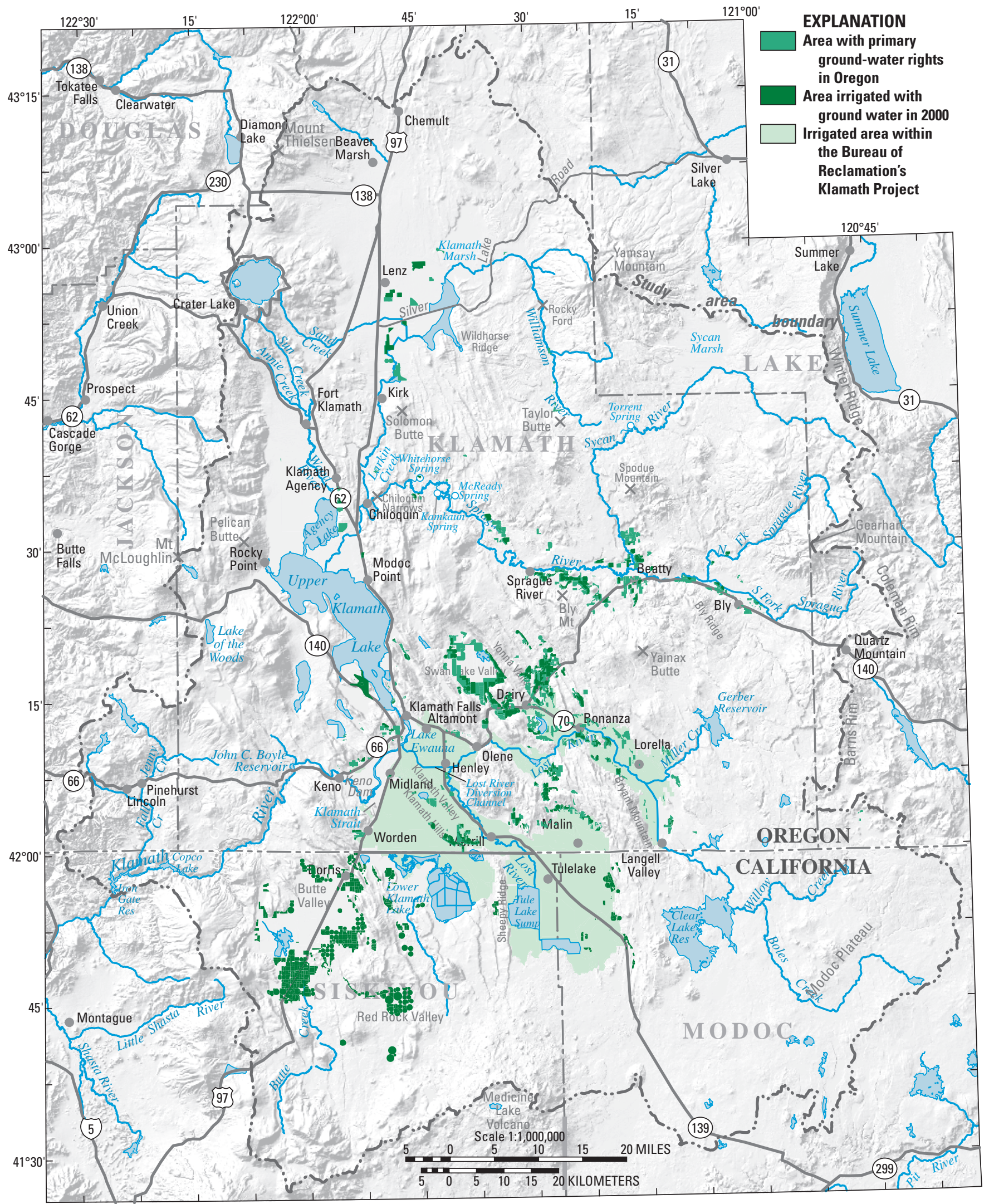

See table of contents for mapping sources

Figure 18. Areas irrigated with ground water in the upper Klamath Basin, Oregon and California, during the 2000 water year, and areas with primary ground-water irrigation rights in Oregon. 


\section{Recent Increases in the Rate of Ground-Water Pumping}

The number of acres irrigated with ground water in the Oregon part of the upper Klamath Basin increased by about 1,800 acres per year between 1950 and 2000. Figure 19 shows that the total acres in the Klamath Basin with primary ground-water rights in Oregon increased slowly with time, with periodic larger increases associated with droughts in the late 1960s, late 1970s, and early 1990s. Historical information on ground-water use in California was not readily available. Ground-water withdrawal in the entire upper Klamath Basin during water year 2000 is estimated to have been about 150,000 acre-ft (table 4). The amounts of historical supplemental ground-water pumping are not known, but generally are assumed to be a fraction of the total amount pumped. The number of acres with supplemental ground-water rights is less than one-half the number with primary rights, and supplemental ground-water use presumably occurs only during dry years or parts of irrigation seasons when surface water is not available.

Since 2001, there has been a marked increase in groundwater pumping in the upper Klamath Basin in response to changes in surface-water management and to a series of consecutive dryer-than-average years. The increase is largely due to government programs such as Reclamation's ground-water acquisition program in 2001 and pilot water bank in 2003, 2004, and 2005 designed to augment surfacewater supplies. The pilot water bank was mandated by the 2002 NOAA Fisheries Biological Opinion (National Marine Fisheries Service, 2002) regarding operation of the Klamath Project and its effects on Klamath River coho salmon.

Pumping for Reclamation programs, which accounts for most the new use, is metered and therefore reasonably well quantified. The amounts of pumping related to Reclamation programs are shown in table 5. Flow-meter data provided to Reclamation by well owners indicates that the total amounts of ground water pumped for the water bank in 2003 and 2004 were approximately 55,700 and 75,800 acre-ft respectively. The reported pumpage for the water bank in 2003 represents a 41-percent increase over the estimated pumping during 2000 in the upper Klamath Basin. The 2004 pumpage represents a 56-percent increase. The spatial distribution of 2003 and 2004 water-bank pumping is shown in figure 20. Most of this increased pumping (about 61,000 acre-ft) was in the lower Lost River and Lower Klamath Lake subbasins. Ground-water pumping in this area prior to 2001 is estimated to be about 28,600 acre-ft. Therefore, the additional 61,000 acre-ft of water-bank pumping during 2004 represents an approximate 3 -fold increase in the total ground-water use in that area. The response to this increased pumping is discussed in the section on hydraulic head fluctuations.

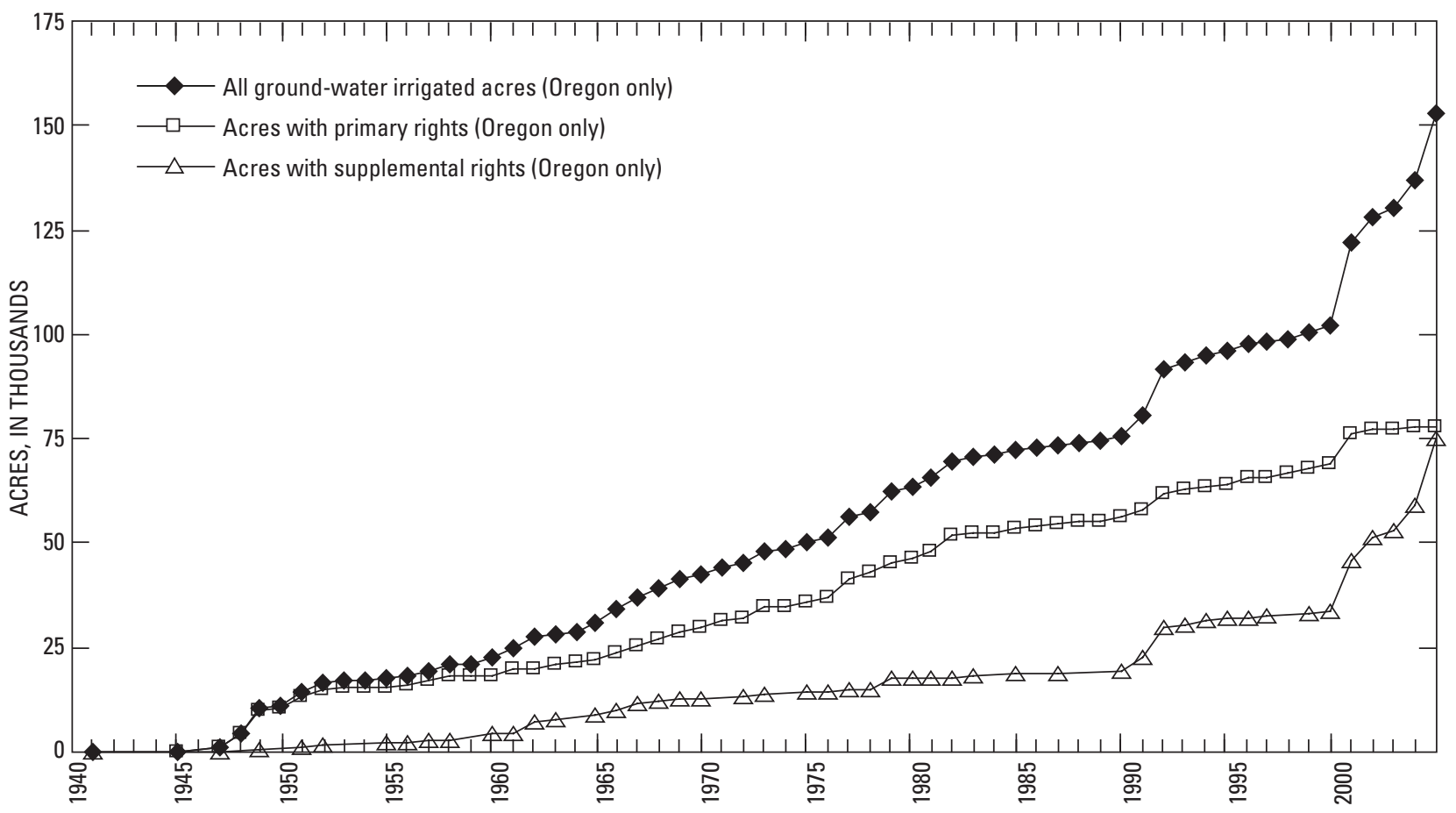

Figure 19. Growth in total acreage with ground-water irrigation rights (primary and supplemental) in the upper Klamath Basin in Oregon through 2005. 
Table 5. Ground-water pumping for the Bureau of Reclamation pilot water bank and ground-water acquisition program, upper Klamath Basin, Oregon and California.

[Data from Bureau of Reclamation and Oregon Water Resources Department. Values in acre-feet]

\begin{tabular}{lrrrc}
\hline \multirow{2}{*}{ Source } & \multicolumn{4}{c}{ Water year } \\
\cline { 2 - 5 } & $\mathbf{2 0 0 1}$ & $\mathbf{2 0 0 2}$ & $\mathbf{2 0 0 3}$ & $\mathbf{2 0 0 4}$ \\
\hline $\begin{array}{c}\text { Reported pumpage from } \\
\text { private wells }\end{array}$ & 59,000 & 0 & 38,900 & 62,900 \\
$\begin{array}{c}\text { Pumpage from Tule Lake } \\
\text { Irrigation District wells }\end{array}$ & 10,300 & 18,600 & 16,800 & 12,900 \\
Total $^{2}$ & 69,300 & 18,600 & 55,700 & 75,800 \\
\hline
\end{tabular}

${ }^{1}$ Includes some irrigation district wells in Oregon.

2 Totals include only pumpage related to government sponsored programs.

\section{Hydraulic Head Distribution and Ground-Water Flow Directions}

Hydraulic head provides the driving force for groundwater flow. Ground water flows from areas of high head toward areas of low head. The change of head with distance is referred to as the "head gradient." In the uppermost parts of aquifer systems, the head generally follows topography and is highest in upland areas, where recharge typically occurs, and lowest in lowland areas, where ground water typically discharges to streams. Hydraulic head often changes with depth as well as horizontally, so ground-water movement typically includes a vertical component of flow. Vertical head gradients are downward in recharge areas; as a result, the elevation of the static (nonpumping) water levels in wells in recharge areas decreases (becomes deeper) with increasing well depth. Head gradients are typically upward in discharge areas, causing the elevation of the static water levels in wells to increase (become shallower) with increasing well depth. If an upward vertical gradient is sufficient, wells of a certain depth may flow at the surface. Flowing artesian wells are common in parts of the Wood and Sprague River subbasins.

Knowing the distribution of hydraulic head is critical to understanding the directions of ground-water flow. Figure 21 shows the generalized hydraulic head distribution in the upper Klamath Basin. Information used to map hydraulic head is obtained from water wells, springs, and streams. The static water level in a well represents the hydraulic head in the aquifer at the depth of the open interval of the well. Water levels in wells open to more than one aquifer, or to large vertical thicknesses in a single aquifer, represent an average of the heads in the open interval. Springs also provide information on hydraulic head distribution, as springs represent places where the water table intersects land surface. Large-volume springs provide useful information on the head in the regional ground-water flow system. Stream reaches that gain flow from ground-water discharge also provide information on the hydraulic head distribution of the ground- water system. Streams that gain large volumes of water due to ground-water inflow are at or below the elevation of the head in the adjacent aquifer system. The mapping of the hydraulic head distribution in the upper Klamath Basin relied upon data from all of these sources. Water level measurements from approximately 1,000 field-located water wells provided most of the detailed information in populated parts of the basin. In sparsely populated and unpopulated parts of the basin, where wells are scarce, springs provided much of the information. Spring elevations generally were obtained from 1:24,000scale topographic maps. Gaining stream reaches were used to constrain head elevations in the Williamson River drainage, Wood River Valley, and in the Klamath River canyon below John C. Boyle Dam. Heads shown on figure 21 in the Lost River subbasin from the outlet of Clear Lake Reservoir (Malone Dam) to Olene Gap were modified from Grondin (2004), and contours in the Butte Valley area were modified from Wood (1960).

The head distribution depicted in figure 21 is a generalization. Limited available data prevented mapping all the complexities of the true head distribution. The map depicts the top of the saturated zone as closely as possible, and generally represents the water-table surface. For low-lying areas, the map is based on static water levels in wells and may not reflect water levels in temporarily saturated soil horizons in irrigated areas. For the Wood River subbasin, the map was drawn using wells penetrating an artesian aquifer, where the heads are locally above land surface. Contours are most detailed and have the smallest intervals in areas where data are plentiful, and more generalized with large intervals where data area sparse.

The highest water-level elevations in the upper Klamath Basin occur in the principal recharge areas. These include the Cascade Range, the highland around Medicine Lake Volcano, and uplands along the eastern margin of the basin, including Yamsay Mountain, Winter Ridge, Gearhart Mountain, and Coleman and Barns Rims. Ground water flows from the Cascade Range eastward toward the lower elevations of the basin. From Crater Lake, head gradients are toward Klamath Marsh and southeastward toward the Wood River valley. South of Crater Lake, ground water flows eastward toward the Wood River Valley and Upper Klamath Lake. Where the Klamath River cuts through the Cascade Range, ground-water flow is generally parallel to the axis of the range and toward the river. From the Medicine Lake highlands, ground water flows generally northward toward Butte Valley and the Lower Klamath and Tule Lake subbasins. Head gradients along the eastern margin of the basin are generally westward. From Yamsay Mountain, ground water flows westward toward the upper Williamson River, and southeastward toward Sycan Marsh. Ground water flows from the Gearhart Mountain area generally southwestward toward the Sycan and Sprague River drainages. From the Barns Rim area, ground water flows generally toward Gerber Reservoir and the upper Lost River. In the Modoc Plateau area east and south of Clear Lake, head gradients slope westward toward the Tule Lake subbasin. 


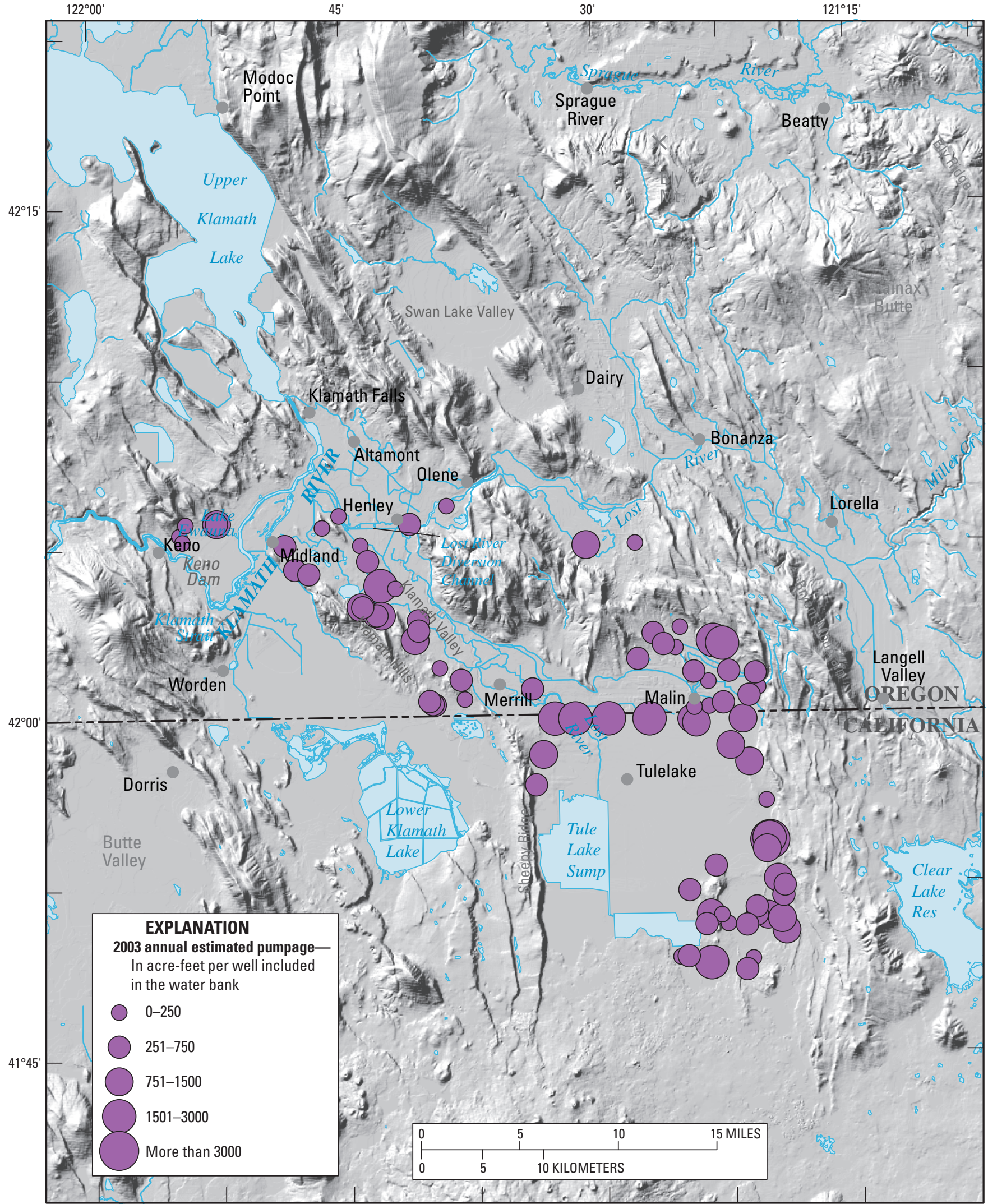

See table of contents for mapping sources

Figure 20. Distribution of ground-water pumping for the Bureau of Reclamation pilot water bank during water years 2003 and 2004, upper Klamath Basin, Oregon and California. (Data from Reclamation water bank records and OWRD meter readings.) 


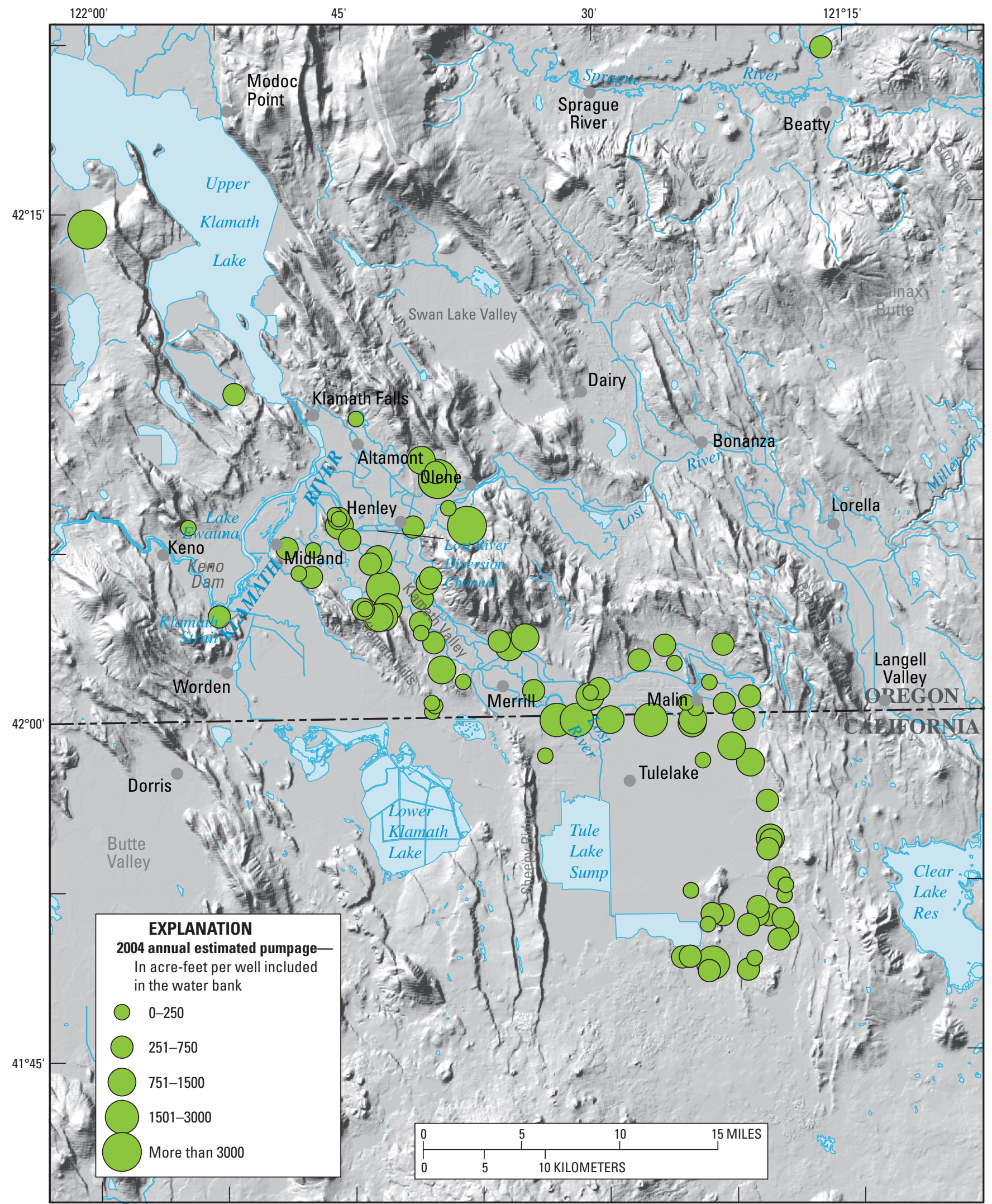

See table of contents for mapping sources

Figure 20.-Continued. 


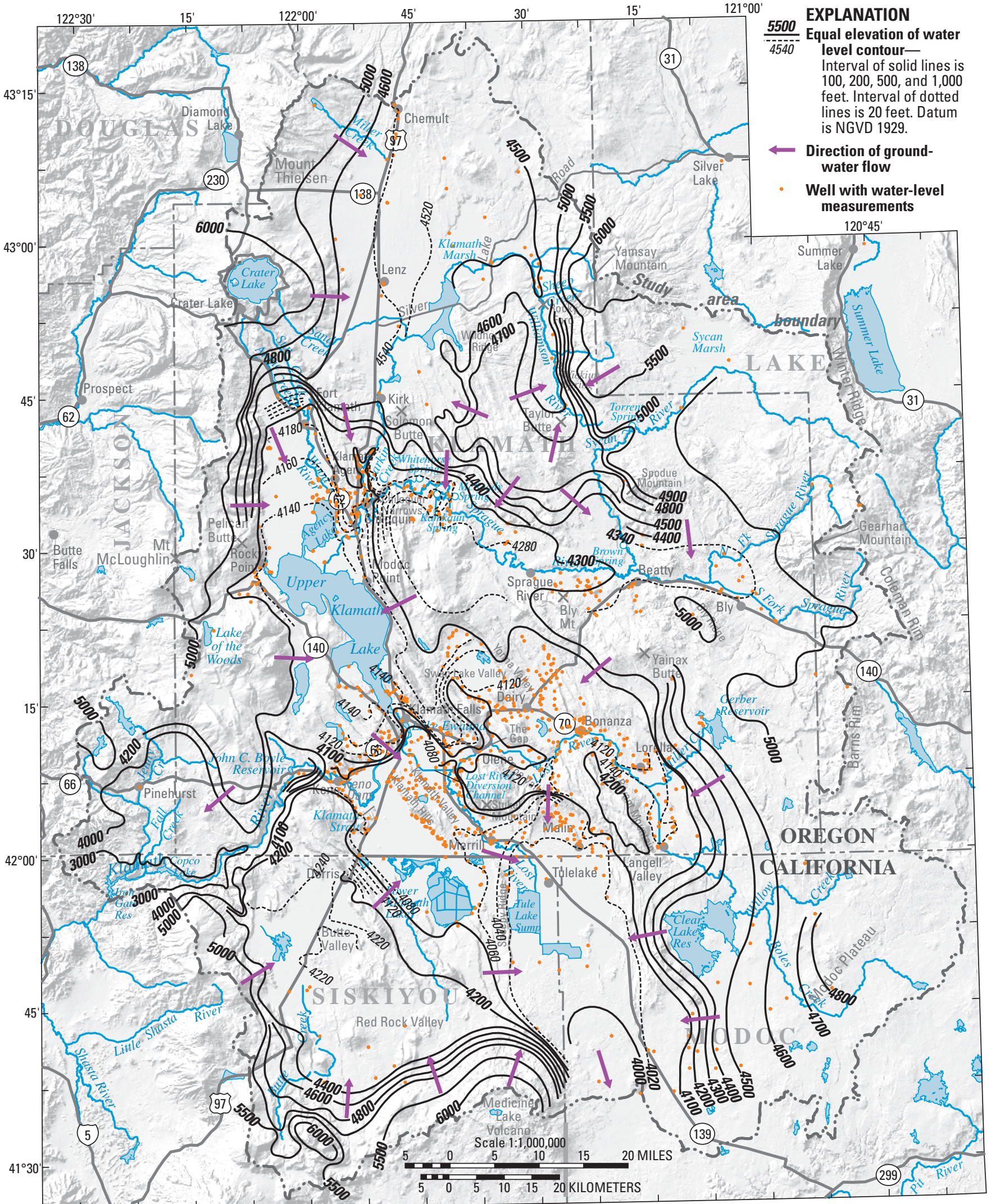

See table of contents for mapping sources

Figure 21. Generalized water-level contours and approximate directions of regional ground-water flow in the upper Klamath Basin, Oregon and California. 


\section{Sprague River Subbasin}

Hydraulic head data in the Sprague River subbasin are largely limited to valley bottoms and are sparse in upland areas. Head data from wells and springs indicate regional ground water flows generally westward from upland areas around Gearhart Mountain. Between Bly and Beatty, ground water flows toward the valley from local recharge areas around Yainax Butte. Ground water also flows toward this part of the valley from the north. These head gradients are consistent with the observed ground-water discharge to the river between Bly and Beatty. Head data also show ground water flowing toward the Whisky Creek area from Yainax Butte and Bly Mountain. Ground water discharges to streams in the Whisky Creek area. The general pattern of ground-water flow toward the valley occurs over most of the length of the Sprague River, although discharge occurs only at specific locations. An upward vertical head gradient occurs locally in the Sprague River Valley. Numerous flowing artesian wells have been mapped in the area between Beatty and the town of Sprague River (Leonard and Harris, 1974). The localized artesian aquifer consists of volcanic, fluvial, and volcaniclastic deposits confined by finegrained lacustrine deposits.

Wells are sparse in the Sycan River subbasin, so ground-water flow directions are inferred mostly from spring altitudes and topography. Ground water appears to flow from Winter Ridge and uplands south of Sycan Marsh generally westward. Ground water flows southeastward toward the Sycan River subbasin from Yamsay Mountain. North of Spodue Mountain, the head gradient is generally northward toward the Sycan River. This is consistent with the groundwater discharge at Torrent Spring. West and south of Spodue Mountain, ground water flows generally southward toward the Sprague River subbasin. Piezometer data from Sycan Marsh show a downward head gradient over most of the area (Leslie Bach, The Nature Conservancy, oral commun., 2005). At the northern end of Sycan Marsh an area on the valley floor contains numerous springs, indicating that upward head gradients occur locally.

\section{Williamson River Subbasin}

The Williamson River originates near Taylor Butte and flows generally northward between Yamsay Mountain and the faulted volcanic upland to the west. Two local recharge areas exist in the upper Williamson River drainage. Head data from wells and springs, along with precipitation data, indicate that Yamsay Mountain is a significant local recharge area and that ground water flows westward from Yamsay Mountain toward the upper Williamson River. Head data, mostly from springs, indicates that the faulted upland west of the uppermost Williamson River also is an area of local recharge, and that ground water flows from that area eastward toward the Williamson River. Head gradients sloping toward the Williamson River from both of these recharge areas causes the river to gain flow due to ground-water discharge in its uppermost reaches.

Data from wells and springs show that the head gradient slopes toward Klamath Marsh from recharge areas in the Cascade Range. Out on the broad plain east of the Cascade Range, the water table is relatively flat, sloping gently toward the marsh. Ground-water flow directions between Klamath Marsh and Kirk are poorly understood due to the lack of data. South of Kirk and west of Solomon Butte, a substantial southward head gradient exists, indicating that ground water flows from this area toward major discharge (spring) areas along the lower Williamson River and tributaries. Ground water also appears to flow south of Solomon Butte toward discharge areas along the lower Sprague River.

Upward vertical gradients are apparent locally in spring areas near the headwaters of the Williamson River and west of Klamath Marsh, where numerous flowing artesian wells have been mapped. Downward head gradients are apparent in well data along the Williamson River near Sheep Creek and in uplands north of the marsh. Well 28S/09E-20BAB northwest of the marsh had a water-level altitude of about 4,510 ft in July 2006 , below the altitude of nearby springs and at roughly the same altitude as the marsh. The water level altitude in well 28S/10E-27DBD was about 4,503 ft in April 2006, several feet below the water level in the marsh. This raises the possibility of subsurface drainage of the northern part of Klamath Marsh, at least during dry climate cycles.

The lower Williamson River (below Kirk) is one of the most significant ground-water discharge areas in the upper Klamath Basin. Between its descent from Kirk and the point where it emerges onto its delta, the Williamson River is largely confined to a relatively narrow valley. Head gradients slope toward the Williamson River in this area from the east and west

\section{Upper Klamath Lake Subbasin}

Well and spring data show that the head gradient slopes eastward from the Cascade Range toward the Wood River Valley north of Upper Klamath Lake. Consequently, many streams emerging from the Cascade Range have large baseflow, and several large springs discharge at the western edge of the valley. A steep gradient toward the basin from the east indicates the potential for ground-water flow across the bounding escarpments from uplands immediately to the east. This gradient from the east appears to extend southward at least to Modoc Point.

A southward hydraulic head gradient from Crater Lake extends to the northern edge of Agency Lake. Between Crater Lake and the northern end of the Wood River Valley, the gradient is 100 to $300 \mathrm{ft} / \mathrm{mi}$. The gradient decreases to about $40 \mathrm{ft} / \mathrm{mi}$ from the northern end of the valley to the area of Fort Klamath, where the gradient continues south at less than 
$5 \mathrm{ft} / \mathrm{mi}$. The head altitudes shown in the Wood River Valley on figure 21 represent water bearing strata (generally sand and pumice) in the upper 100-300 ft of the basin-fill deposits. These strata are overlain and confined by clay layers, resulting in artesian conditions, with heads above land surface over much of the area. This is the principal developed aquifer in the Wood River Valley.

Little head data exist for the ridge east of Upper Klamath Lake; however, springs along the margin of Upper Klamath Lake indicate a head gradient toward the lake, consistent with the area to the north. Head data in the Rocky Point area indicate a gradient toward the lake ranging from more than $100 \mathrm{ft} / \mathrm{mi}$ in the Cascade Range to about $15 \mathrm{ft} / \mathrm{mi}$ on the valley floor. The gradients toward Upper Klamath Lake from the north, east, and west suggest that ground water is discharging to the lake. South of Upper Klamath Lake, however, the head gradient slopes southeastward toward the Klamath River Valley and the Lower Klamath Lake subbasin.

\section{Upper Lost River Subbasin}

Much of head data and analysis for the upper Lost River subbasin are from Grondin (2004). The Lost River originates at Clear Lake Reservoir and winds through a complex of interconnected structural basins north to Bonanza, west to Olene Gap, and then generally southwestward to Tule Lake. Head gradients indicate that ground water flows generally toward the upper Lost River Valley from regional recharge areas to the east and from local recharge associated with Bryant Mountain and other uplands surrounding the subbasin. Although data are scarce, ground water appears also to flow from recharge areas associated with uplands around Yainax Butte and Bly Mountain. The hydraulic head gradient is exceedingly flat in the alluvial valleys of the upper Lost River subbasin; however, the water-table surface likely is variably influenced by pumping. Although the head gradient in the valley is small, it does indicate that ground water moves generally down valley.

Ground-water flow directions in structural valleys adjacent to the upper Lost River subbasin, such as Swan Lake and Yonna Valleys, appear to be generally toward the Lost River. One exception is the southernmost Poe Valley, where the head gradient slopes steeply southward toward the Tule Lake subbasin. Another exception is the southern part of Swan Lake Valley, where the gradient appears to slope steeply toward the southwest. The path that ground water follows out of the southwestern margin of the Swan Lake Valley is unclear, but most likely it is southward toward Olene Gap.

Vertical head gradients are variable in the upper Lost River subbasin. Grondin (2004) evaluated well log information, geophysical data, and water-level measurements, and found downward vertical gradients between basin-fill sediments and the underlying basalt to be common along valley margins and upward gradients in valley centers in the eastern Lost River subbasin. Vertical gradients within the sedimentary section or the basalt were not common. Downward vertical gradients were observed in the Swan Lake Valley, but heads in that area generally were above the elevation of the Lost River.

\section{Klamath Valley}

The Klamath Valley area comprises the Lost River drainage from Olene Gap to about Merrill and includes the area immediately south of Klamath Falls and northeast of the Klamath Hills. Ground water flows into the Klamath Valley from the area of Klamath Falls and the uplands to the southwest. Ground water also flows into the Klamath Valley from uplands to the northeast and the Olene Gap area. Local recharge creates a gradient toward the valley from the Klamath Hills as well. Within the Klamath Valley, ground water flows southeastward toward the Tule Lake subbasin. Head gradients on the valley floor are low, averaging 2-3 ft/mi. Southeast of Merrill and north of Sheepy Ridge, the head gradient steepens to about $20 \mathrm{ft} / \mathrm{mi}$. This steepening coincides with a possible subsurface extension of Sheepy Ridge and the margin of the Tule Lake structural basin.

\section{Butte Valley/Red Rock Valley Area}

Butte Valley is an internally drained structural basin. The head distribution in the Butte Valley area shown on figure 21 is modified from Wood (1960) and augmented in adjacent uplands using additional well and spring data. Since the creation of Wood's (1960) water-table map, water levels have declined in parts of Butte Valley as much as 15-25 ft in response to pumping and climate. Declines occurred primarily during 1975-1990 and since 2000. The declines appear to be localized, as water levels have been stable in other parts of Butte Valley. Localized declines since the 1950s have changed the configuration of the water-table surface in Butte Valley, but have not changed the overall regional ground-water flow directions.

Head data show a steep gradient toward Butte Valley from volcanic uplands to the south and west. Gradients from the uplands to the south and around Medicine Lake Volcano range from 100 to $300 \mathrm{ft} / \mathrm{mi}$. In the lower elevation parts of the Butte Valley/Red Rock Valley area, gradients flatten markedly to less than a few feet per mile. Water-table altitudes are between 4,200 and 4,230 ft over much of this area. The watertable surface is not smooth, but is affected by local geology, surface-water hydrology, and pumping. There is a regional northeastward slope to the gradient, indicating ground-water flow from the Butte Valley/Red Rock Valley area toward the Lower Klamath Lake subbasin across the intervening uplands. The gradient steepens beneath the intervening uplands to roughly $50 \mathrm{ft} / \mathrm{mi}$. 


\section{Lower Klamath Lake Subbasin}

Lower Klamath Lake occupies a structural basin bounded roughly by the Klamath River, the Klamath Hills, uplands to the southwest, and Sheepy Ridge. Hydraulic head data (fig. 21) indicate ground-water flow toward Lower Klamath Lake from uplands just north of the Klamath River. There also is flow from the Butte Valley/Red Rock Valley area southwest of the basin. Heads in the Lower Klamath Lake subbasin and Klamath Valley are similar; however, in the Klamath Hills, which separate the two subbasins, heads are slightly higher, indicating local recharge or regional discharge. The higher heads cause a small gradient toward the Lower Klamath Lake subbasin from the Klamath Hills.

The hydraulic head gradient is very small on the floor of the Lower Klamath Lake subbasin, sloping gently southeastward at 1 to $2 \mathrm{ft} / \mathrm{mi}$ over most of the area. East of the Lower Klamath Lake, near Sheepy Ridge, the gradient steepens to approximately $16 \mathrm{ft} / \mathrm{mi}$ toward the Tule Lake subbasin, indicating ground-water flow in that direction. This is consistent with isotopic data from deep wells in the Tule Lake subbasin, which indicate the deep aquifer there contains a fraction of water from the Lower Klamath Lake subbasin (Palmer and others, 2007).

\section{Tule Lake Subbasin}

Hydraulic head data from wells shows that ground water flows toward the Tule Lake subbasin from the north, east, and west. Ground water flows from the north from the Klamath Valley and southernmost Poe Valley. Ground water flows eastward from the Lower Klamath Lake subbasin into the Tule Lake subbasin as described in the preceding section. A relatively steep gradient of up to $100 \mathrm{ft} / \mathrm{mi}$ toward the Tule Lake subbasin occurs in the Clear Lake area and on the Modoc Plateau to the south. The ground-water flow directions inferred from hydraulic head gradients are consistent with isotopic data that suggest that water produced by deep wells in the Tule Lake subbasin originated as recharge in the interior and eastern parts of the upper Klamath Basin with a probable component of water from the Lower Klamath Lake subbasin (Palmer and others, 2007). Head gradients are small on the valley floor, being less than $1 \mathrm{ft} / \mathrm{mi}$ in much of the area. Analysis by CDWR (Eaves and others, 2002) indicates that the head gradients in lavas underlying basin-filling sediments slope gently toward the south at $2.5 \mathrm{ft} / \mathrm{mi}$ or less. Gradients are much smaller in the shallow water-bearing zones in the sedimentary section, and are generally toward the Tule Lake Sump. Head data from wells indicate ground-water flow southward out of the Tule Lake subbasin, east of Medicine Lake Volcano, toward the Pit River Basin south of the study area.
Subsurface drainage from the Tule Lake subbasin is consistent with historical observations in the area, many of which were summarized by La Rue (1922). Much of this evidence was manifest prior to the draining of Tule Lake, which covered an area of about $150 \mathrm{mi}^{2}$ prior to draining (according to a 1905 Reclamation survey map). La Rue cited Native American accounts of a whirlpool in the lake, and stated that at high stage water discharged into lava flows along the southern margin (a phenomenon common in the lavas of central Oregon). Early efforts to drain the lake included construction of pits in the lava designed to act as drains. La Rue noted that silt deposits in the lava slope southward, away from the lake. He also considered the fact that "waters of Tule Lake are fresh and the lake bed comparatively free of salts" as proof that the lake "in the past had an outlet."

\section{Klamath Canyon Area}

The Klamath Canyon area includes the reach of the Klamath River between John C. Boyle and Iron Gate Dams. Along most of this reach, the river occupies a steep-walled canyon as it cuts through the Cascade Range. The canyon widens between the upper end of Copco Lake reservoir and Iron Gate Dam, becoming narrow again downstream. Data from sparse wells and numerous springs indicate that ground water flows toward the river throughout the Klamath Canyon area.

\section{Fluctuations in Hydraulic Head}

Hydraulic head fluctuates with time in response to external stresses, the most important of which are variations in natural recharge from precipitation, pumping, lake stage, and recharge from canal leakage. These fluctuations are manifest as variations in the water levels in wells.

Ground-water-level fluctuation data are collected by taking multiple water-level measurements in the same well over a period of time. Multiple water-level measurements are available for 257 wells in the upper Klamath Basin. Observation wells are monitored periodically by the USGS, OWRD, and CDWR. Wells have been monitored for periods ranging from less than 1 year to more than 50 years, and measurements have been made at intervals ranging from once every 2 hours (using automated recording devices) to a few times a year. The short-interval measurements effectively create a continuous record of water-level fluctuations.

Ninety-one wells in the basin have been monitored by OWRD, some for periods greater than 50 years. Twenty wells with relatively long-term (10-50 years) records currently are being measured by OWRD (fig. 22). Measurements in those wells generally are made one to four times a year. Sixty-two 


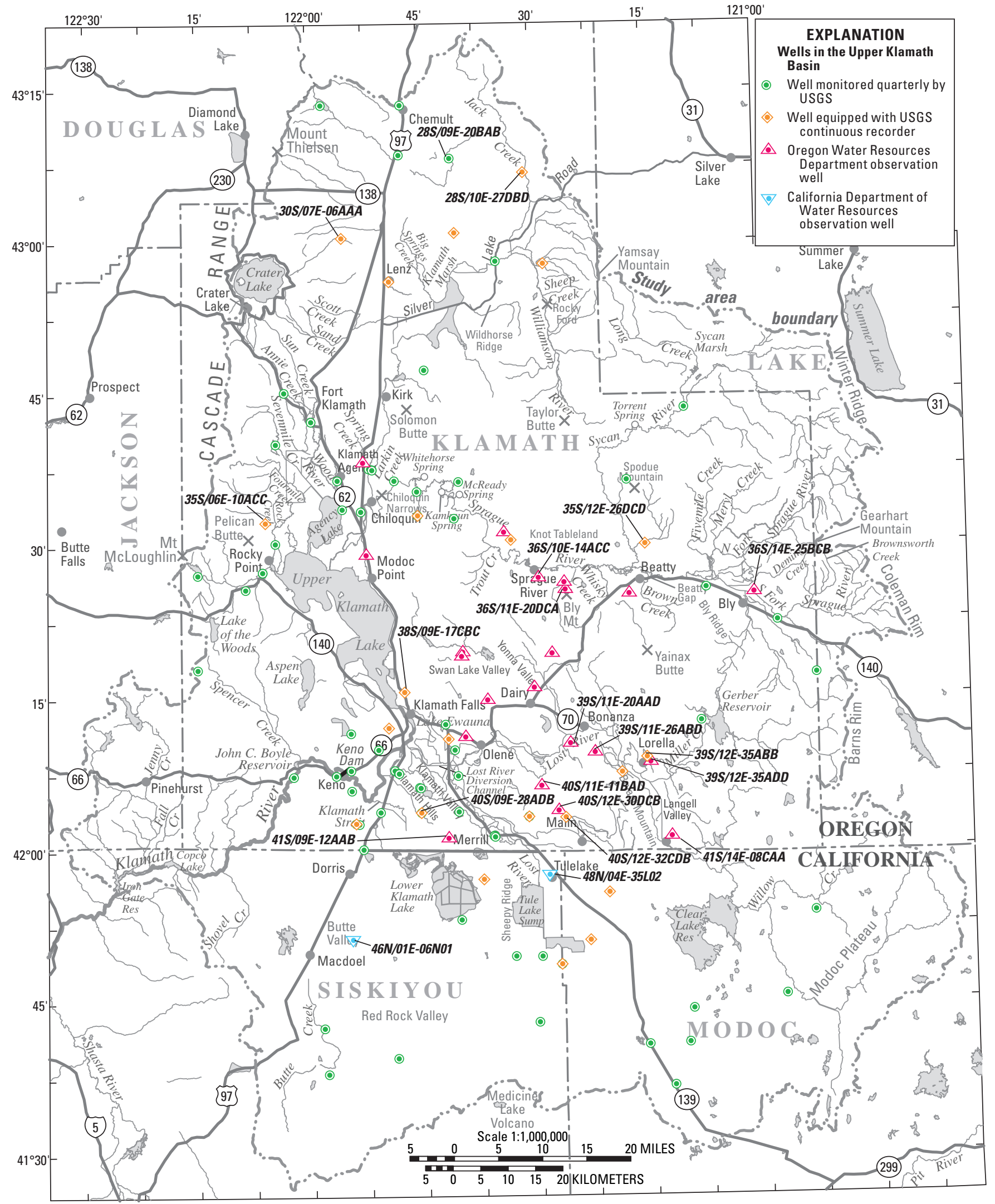

See table of contents for mapping sources

Figure 22. Selected observation wells in the upper Klamath Basin, Oregon and California. Location information is only shown for wells specifically referenced in this report. 
wells were measured quarterly during this study by the USGS for periods ranging from 1 to 6 years (fig. 22). Nineteen wells were instrumented with continuous recorders, devices that measure and record the water-level elevation every 2 hours. Graphs of water-level fluctuations in all of the wells monitored by the USGS are available on the USGS web site (http:// waterdata.usgs.gov/or/nwis/gw). Not all wells monitored in the upper Klamath Basin are shown in figure 22. Scores of additional wells have been or currently are monitored by the CDWR and the OWRD for specific purposes. Data from the wells shown in figure 22, which includes all wells monitored by the USGS, provide a comprehensive picture of the dynamic nature of the regional ground-water system.

\section{Climate-Induced Fluctuations}

Water levels in most wells fluctuate in response to natural, climate-induced changes in recharge. The greatest response to climate-induced water-level fluctuations in the upper Klamath Basin occurs in the Cascade Range. The response to diminished precipitation (and hence recharge) in the Cascade Range during the current drought cycle is exemplified by the hydrograph of well 30S/07E-06AAA on the lower eastern flank of the Crater Lake highlands (fig. 23). The water level in that well has declined approximately $12 \mathrm{ft}$ since 2000 because of climate-related decreased recharge. On the eastern side of the basin, a similar post-2000 trend exists in well 36S/14E$25 \mathrm{BCB}$ (fig. 24), but the magnitude of the recent decline is less. A comparison of these water-level fluctuations with precipitation at Crater Lake in the Cascade Range (fig. 24) shows that periods of rising ground-water levels generally correspond to periods of increasing precipitation, and falling water-levels correspond to periods of decreasing precipitation. Figure 24 also shows that the decadal drought cycles are responsible for the largest water-level fluctuations. During periods of abundant precipitation, the rate of ground-water recharge exceeds, at least temporarily, the rate of discharge. When ground-water recharge exceeds discharge, the amount of ground water in storage must increase, causing the water table to rise. During dry periods, in contrast, the rate of discharge exceeds the rate of recharge, and ground-water levels decline as a result.

Water table fluctuations in response to variations in recharge are most prominent in the Cascade Range, the primary recharge area. Climate-related fluctuations may be difficult to discern in some interior parts of the basin, for two reasons. First, precipitation and, hence, recharge are comparatively small in the interior parts of the basin, so climate-induced water-level fluctuations are correspondingly small. Second, water levels in these areas are affected by ground-water pumping, canal operation, and irrigation, the effects of which can mask the climate signal.

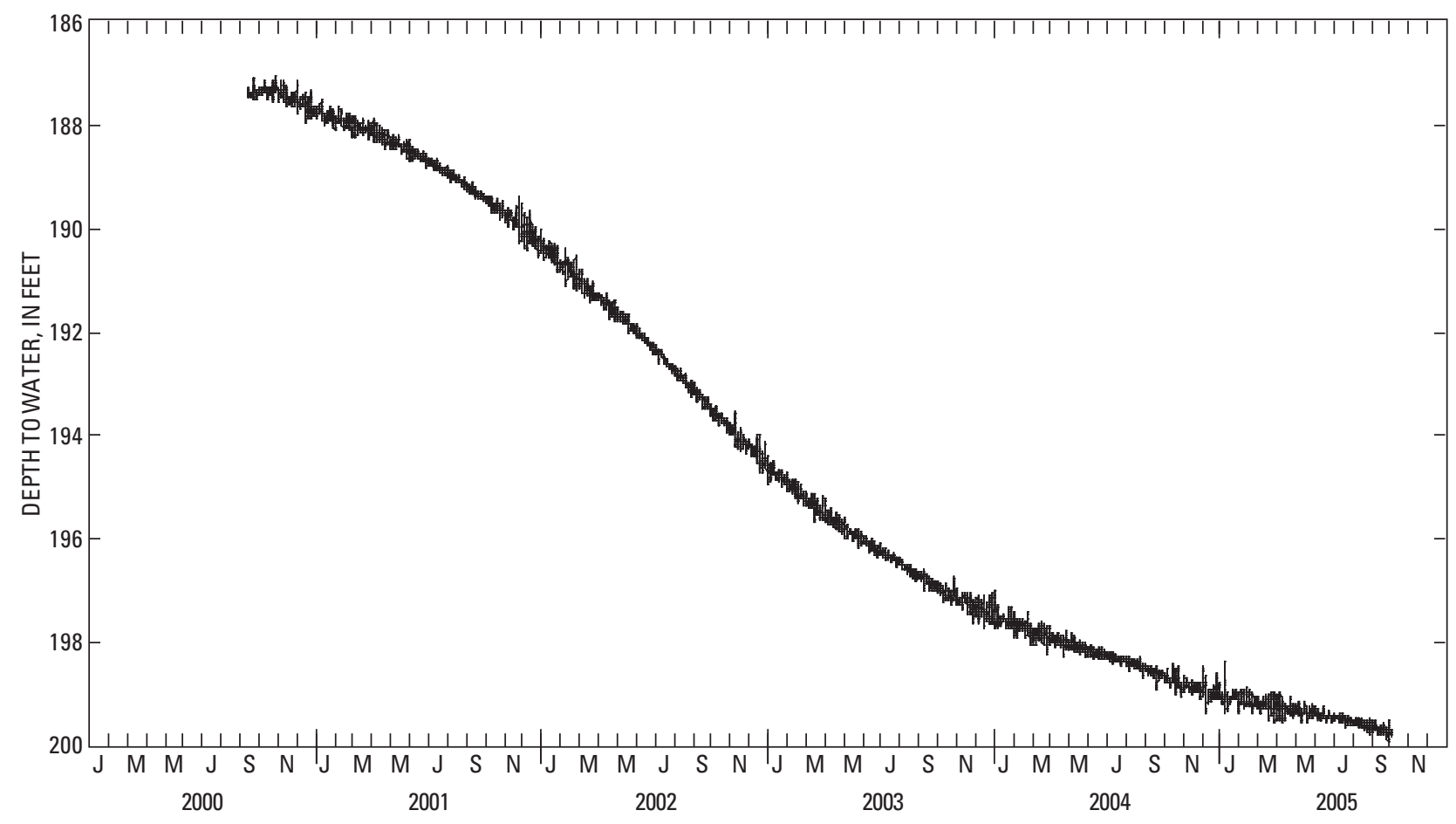

Figure 23. Water-level fluctuations in well 30S/07E-06AAA near Bear Creek northeast of Crater Lake, Oregon. 


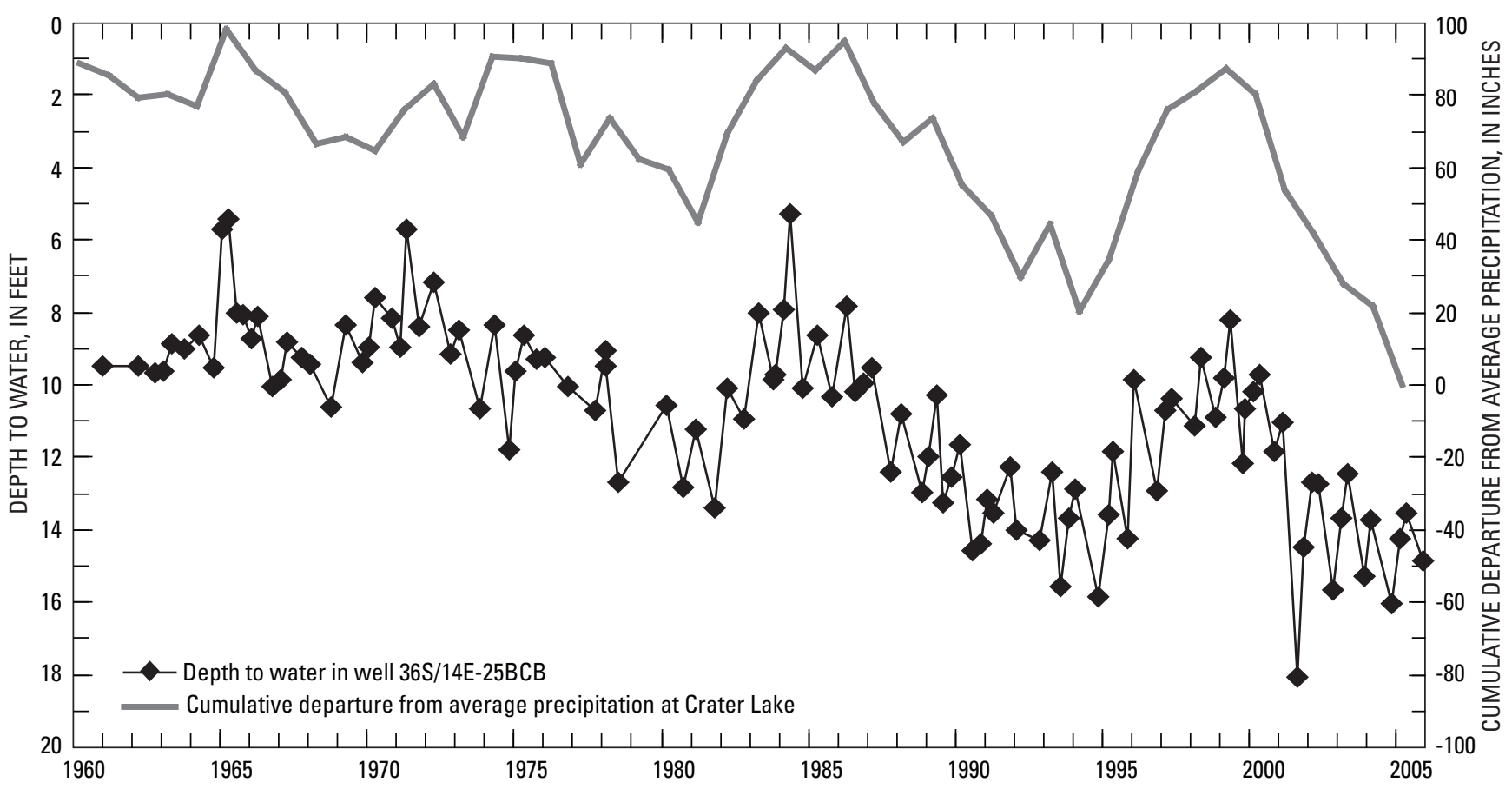

Figure 24. Water-level fluctuations in well 36S/14E-25BCB near Bly and the cumulative departure from average precipitation at Crater Lake, Oregon.

\section{Pumping-Induced Fluctuations}

When a well is pumped, the water table near the well declines due to the removal of ground water from storage. A conical depression centered on the well develops on the water table (or potentiometric surface in the case of a confined aquifer) and expands until it captures sufficient discharge and (or) induces enough new recharge to equal the pumping rate. After pumping ceases, the water table recovers as the aquifer returns to pre-pumping conditions. Key factors that determine the magnitude of water-table fluctuations caused by pumping are the aquifer characteristics, the rate and duration of pumping, the presence of aquifer boundaries, and the number of wells affecting the water table in a given area. In aquifers that have low permeability, pumping-induced water-table fluctuations can be large and even interfere with the operation of nearby wells. If the long-term average pumping rate exceeds the rate at which the aquifer can supply water, water levels will not recover fully and long-term water-level declines will occur.

Seasonal pumping affects many wells throughout the upper Klamath Basin. Water-level fluctuations from pumping generally range from a few feet to $20 \mathrm{ft}$. Pumping effects can be seen in the hydrographs for a well 35S/12E-26DCD near Beatty (fig. 25) and well 40S/12E-32CDB near Malin (fig. 26). Hydrographs for both wells have a steep drawdown curve during the summer followed by a broad recovery curve that rises throughout the winter and spring. Hydrographs for the wells in figures 25 and 26 also show slight year-to-year declines, probably due to a combination of pumping and climate.

\section{Response to Canal Leakage}

Water-level fluctuations due to irrigation-canal leakage occur in many wells throughout the irrigated areas in the central part of the study area, with water levels rising during the irrigation season when canals are flowing, and falling when canals are dry. The magnitude of these annual fluctuations varies with the proximity of the well to the canal, the depth of the well, and the local geology. Annual fluctuations due to canal leakage of more than $10 \mathrm{ft}$ have been documented (fig. 27), although fluctuations in the range of 4 to $5 \mathrm{ft}$ are more common.

The water-level response in well 40S/09E-28ADB (fig. 27) is an example of canal and drain influences on wells open to sedimentary materials. This well is constructed into late Tertiary sediment on the northwest flank of the Klamath Hills, about $900 \mathrm{ft}$ from the North Canal. The North Canal is diverted directly from the Klamath River and operates almost continuously. Although the water-level in the well responds to the canal operation nearly year-round, the response is most prevalent during the summer irrigation season. Note that the ground-water response to canal leakage was almost nonexistent in 2001, when no water flowed through the Klamath Project canals for most of the irrigation season (fig. 27).

Ground-water levels can respond rapidly to canal leakage, even at considerable depths, particularly in areas where fractured lava is the predominant rock type. Well 39S/12E-35ABB was constructed to allow separate waterlevel measurements in two distinct water-bearing intervals. 


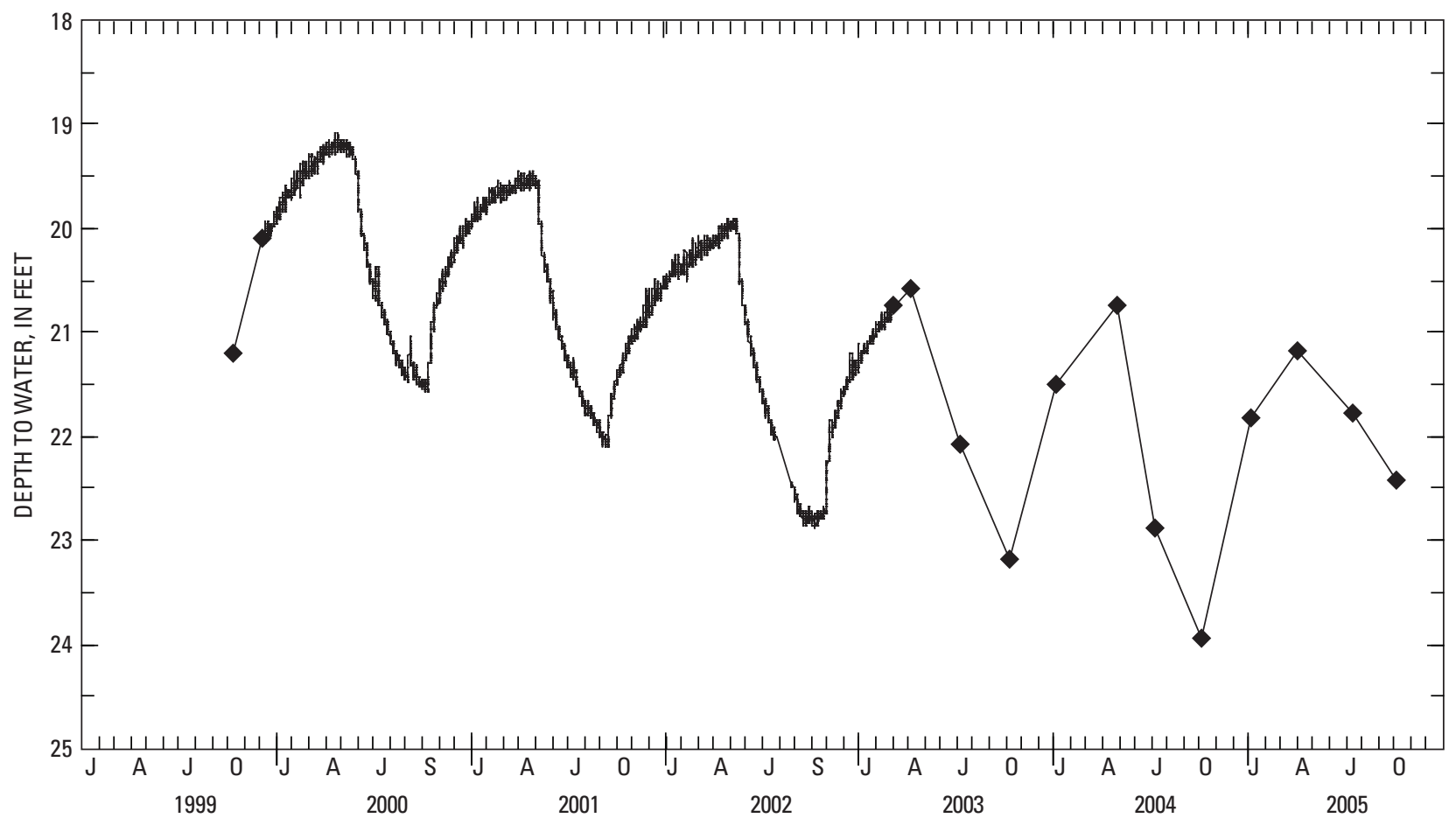

Figure 25. Water-level fluctuations in well 35S/12E-26DCD north of Beatty, Oregon.

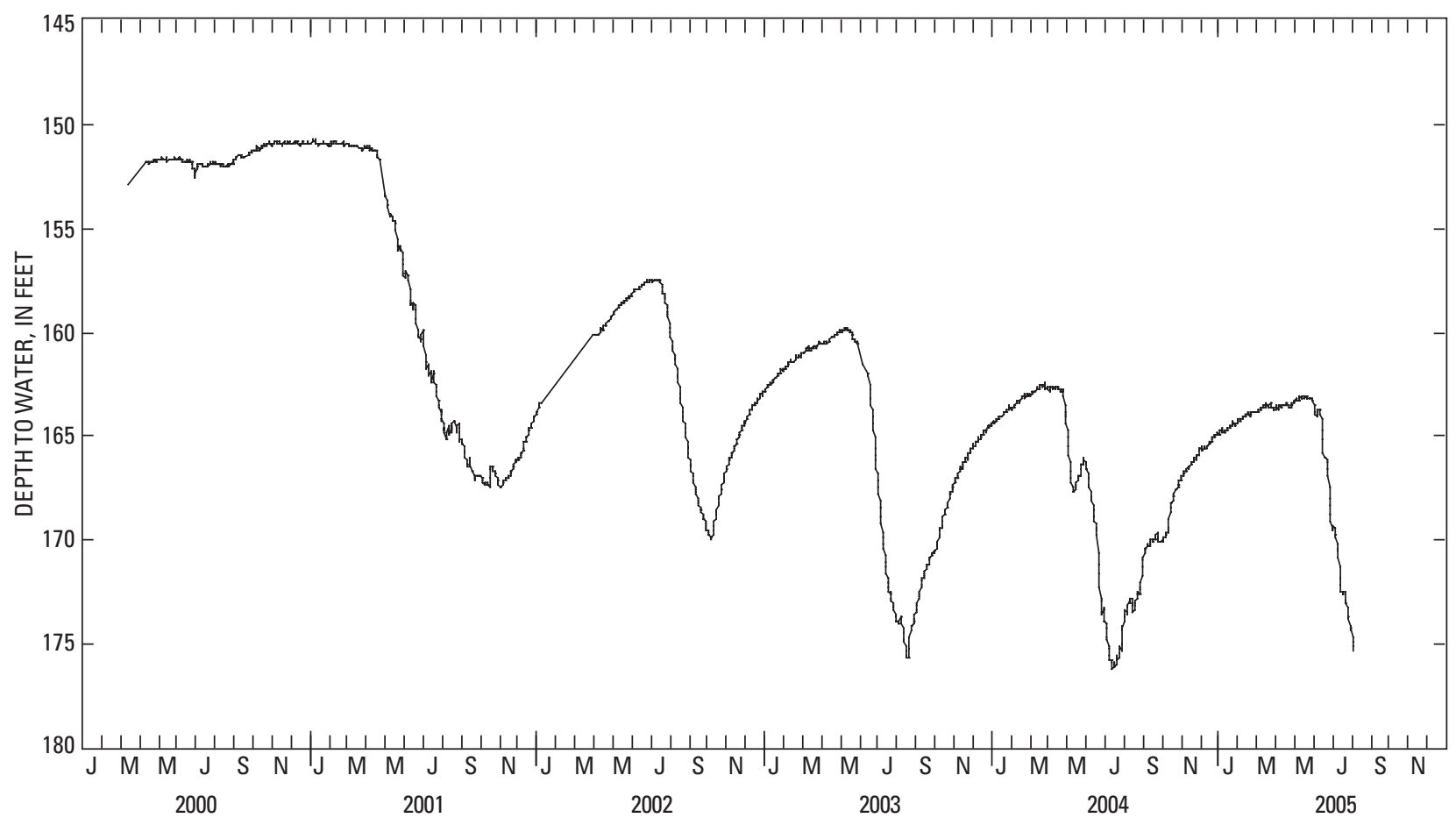

Figure 26. Water-level fluctuations in well 40S/12E-32CDB northwest of Malin, Oregon. 


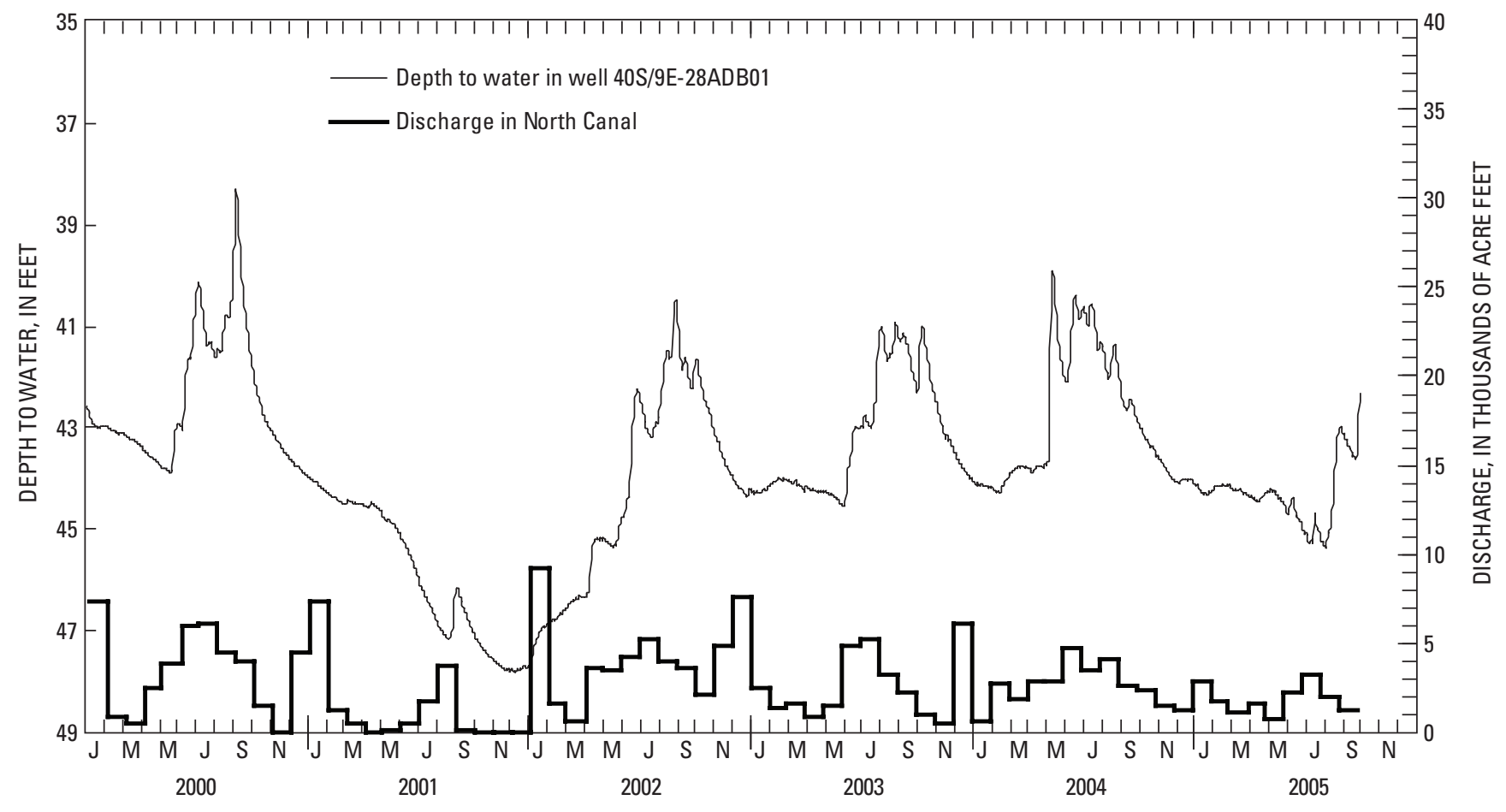

Figure 27. Water-level fluctuations in well 40S/09E-28ADB on the southwest side of the Klamath Hills, Oregon, and monthly discharge in the nearby North Canal.

The upper interval, which responds primarily to the canal operation, is open from 92 to $516 \mathrm{ft}$ below land surface. The main water-bearing zone is in pyroclastic material between 305 and $360 \mathrm{ft}$ below land surface, and is overlain by lava flows. The water level in the upper interval of this well responds in a matter of days to the operation of the Langell Valley Irrigation District canal system (fig. 28). The water level starts to rise shortly after the canals start flowing, peaking late in the irrigation season, and dropping soon after canals are shut off for the season. The rapid response of the water table to canal leakage at such depth likely is due to rapid downward movement of water through interconnected vertical fractures in the lava flows. The lower water-bearing interval in the observation well is open from 950 to $1,005 \mathrm{ft}$ below land surface, and is not influenced by canal operation. Both the upper and lower water-bearing zones in this well respond to the pumping effects of nearby wells (fig. 29). Individual wells can respond to both canal operation and pumping.

\section{Response to Lake Stage}

As previously discussed, ground water discharges to Upper Klamath Lake. The lake, therefore, represents a local boundary to the regional ground-water system. As a result, water levels in most wells near the lake track variations in lake stage. The water-level in well 35S/06E-10ACC (fig. 30), drilled on the lower northeast flank of Pelican Butte, closely follows the stage in Upper Klamath Lake. The well, about
$3,500 \mathrm{ft}$ from the shoreline of the lake, is constructed into layered lava flows that are saturated below a depth of about $470 \mathrm{ft}$ (altitude 4,140). Well 38S/09E-17CBC, located near the Oregon Institute of Technology campus in Klamath Falls, also fluctuates with the stage of Upper Klamath Lake (fig. 31). The well is about $5,200 \mathrm{ft}$ from the lake, and is constructed into interbedded sediment and lava to a total depth of $425 \mathrm{ft}$.

\section{Long-Term Water-Table Fluctuations}

Water levels in wells in the upper Klamath Basin that have been monitored for several decades show fluctuations in response to many of the stresses just discussed. In addition, measurements in most of the wells also reflect decadal scale, wet-dry climate cycles, with some showing the effects of multiyear pumping stresses. Water level trends observed near Bly (well 36S/14E-25BCB), Bonanza (well 39S/11E-20AAD), and the southern Langell Valley (well 41S/14E-08CAA) exemplify areas where ground-water levels are responding mostly to variations in recharge (climate) (fig. 32), showing decadal scale fluctuations of 4-5 ft.

The ground-water flow system appears to be responding to prolonged pumping stresses in several other areas in the upper Klamath Basin, including the area between the communities of Sprague River and Beatty, parts of Butte Valley, south Poe Valley and the area of the Shasta View Irrigation District just north of Malin, parts of west Langell Valley, an area east of Lorella, and the Klamath Valley. 


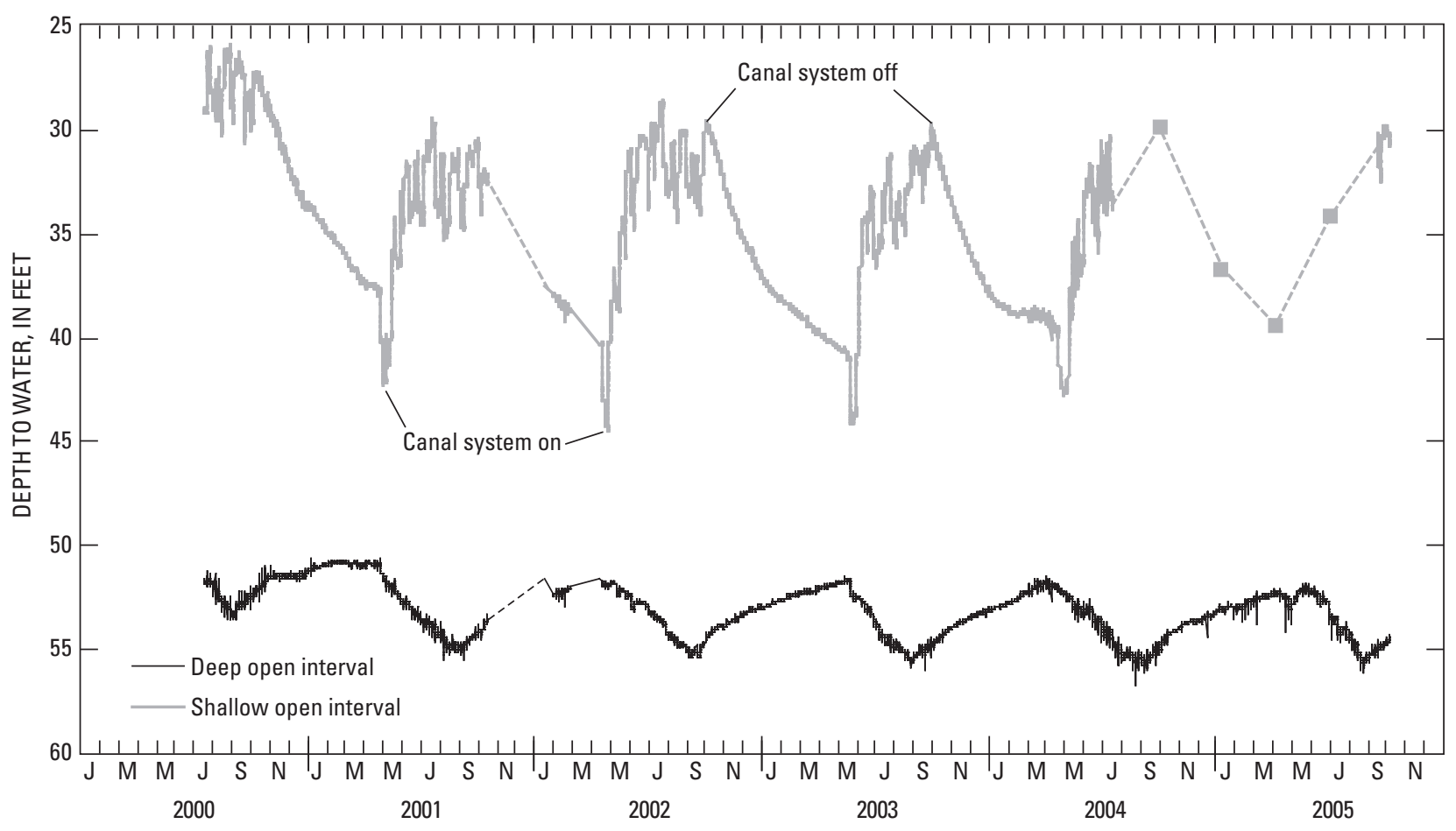

Figure 28. Water-level fluctuations in shallow and deep water-bearing zones in double-completion well 39S/12E$35 \mathrm{ABB}$ near Lorella, Oregon.

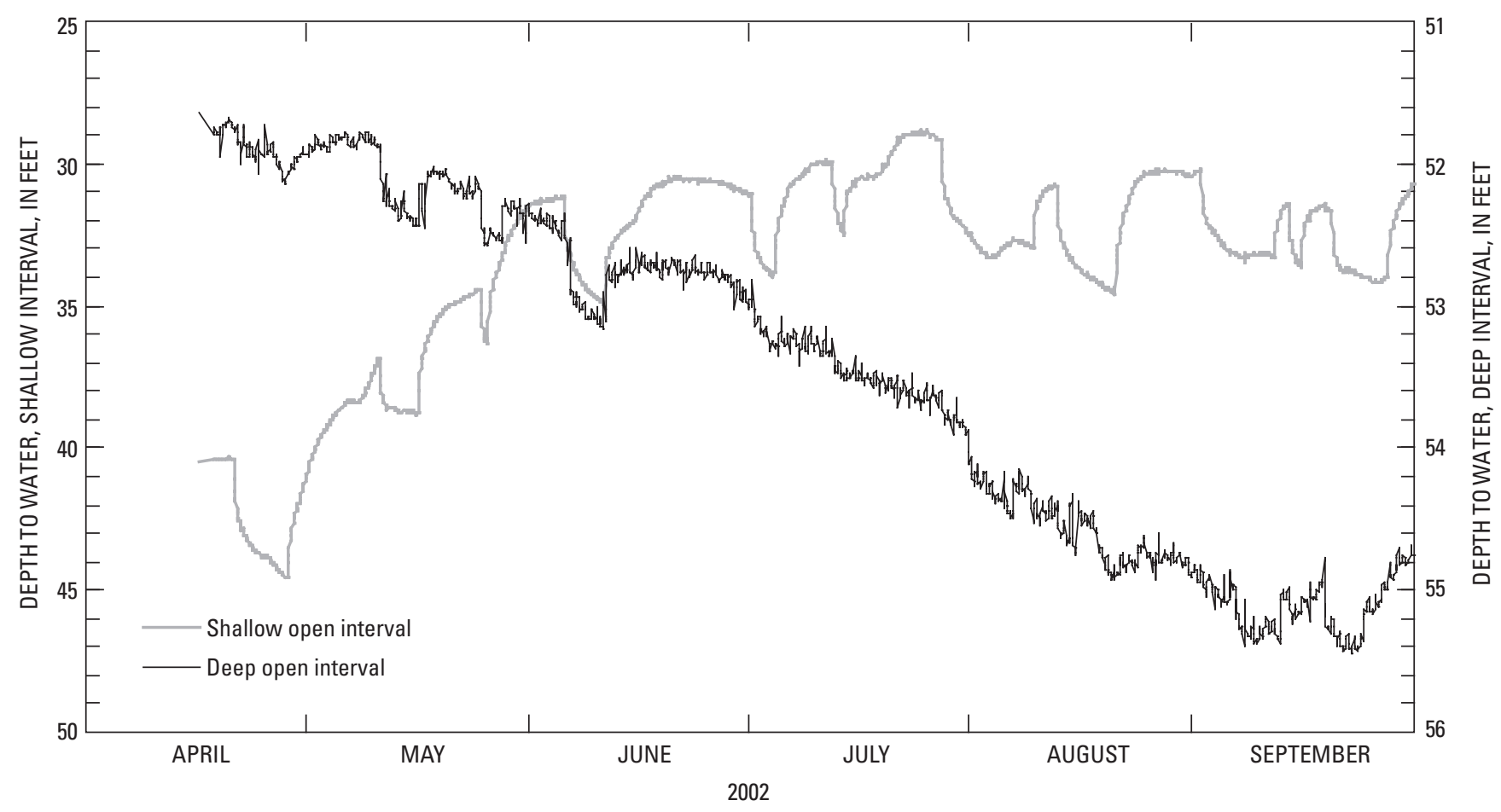

Figure 29. Water-level fluctuations in shallow and deep water-bearing zones in double-completion well 39S/12E35ABB near Lorella, Oregon, with time scale expanded to show effects of nearby ground-water pumping. 


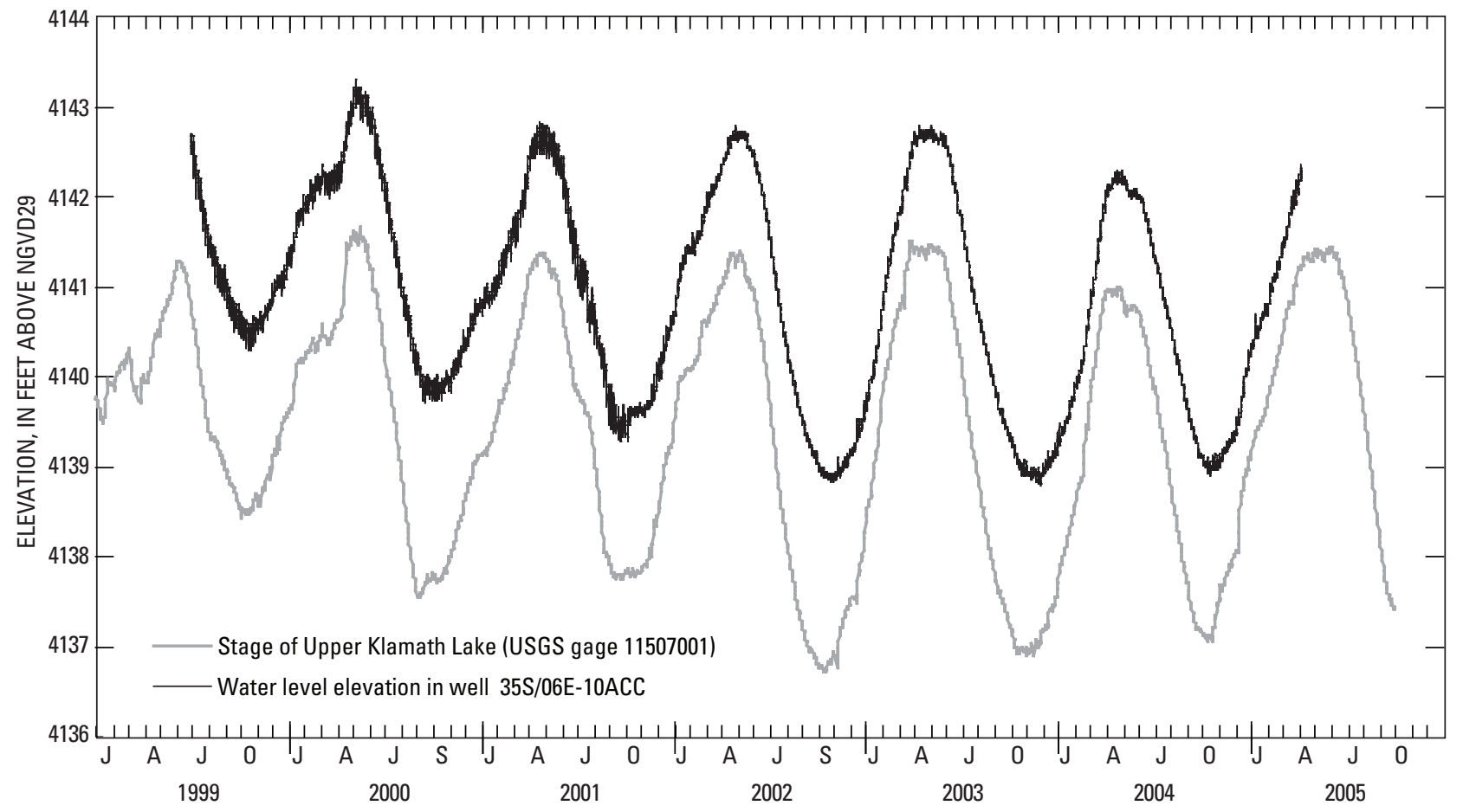

Figure 30. Water-level fluctuations in well 35S/06E-10ACC near Pelican Butte and stage in Upper Klamath Lake, Oregon.

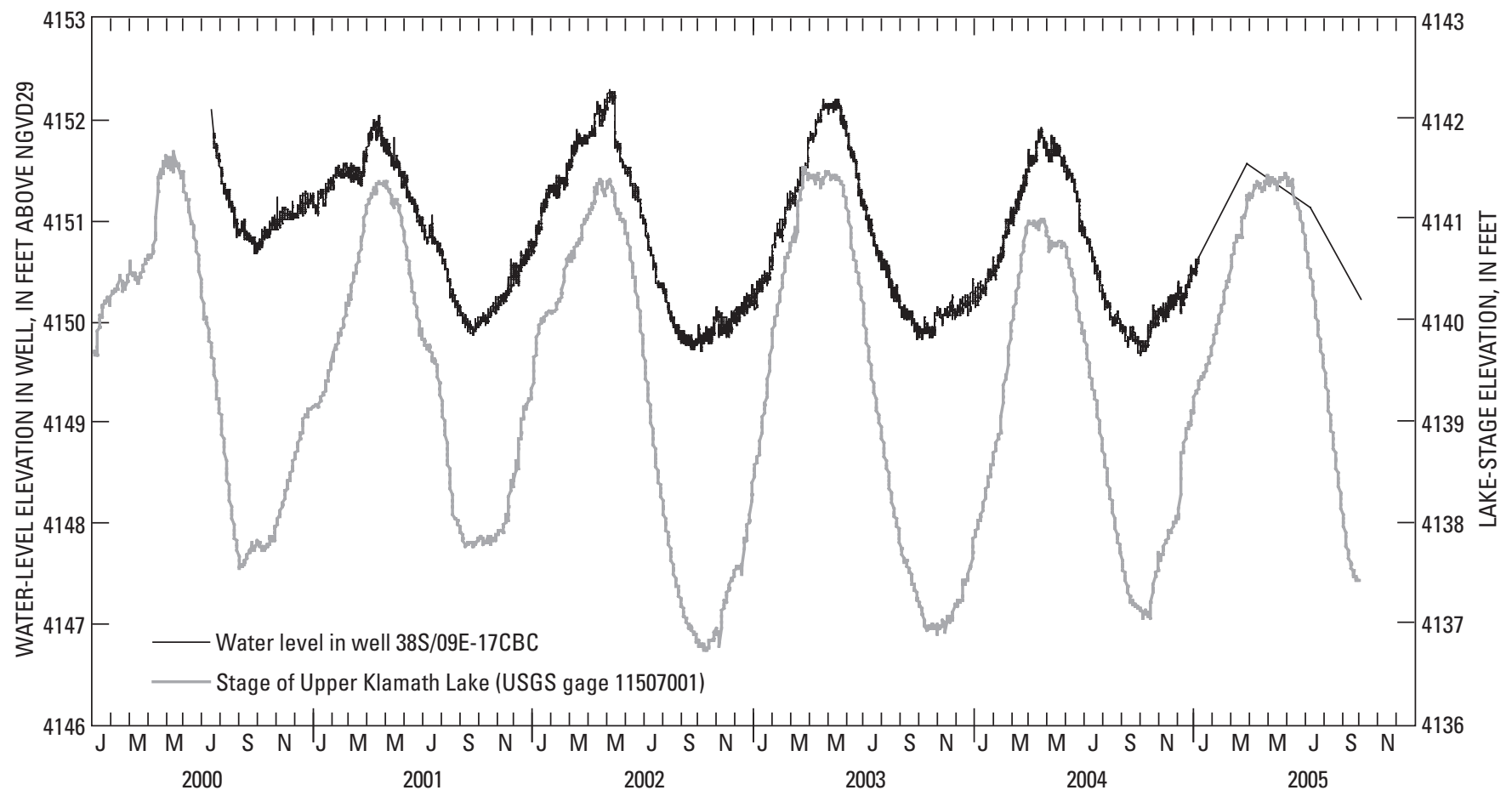

Figure 31. Water-level fluctuations in well 38S/09E-17CBC in the north part of Klamath Falls and stage in Upper Klamath Lake, Oregon. 

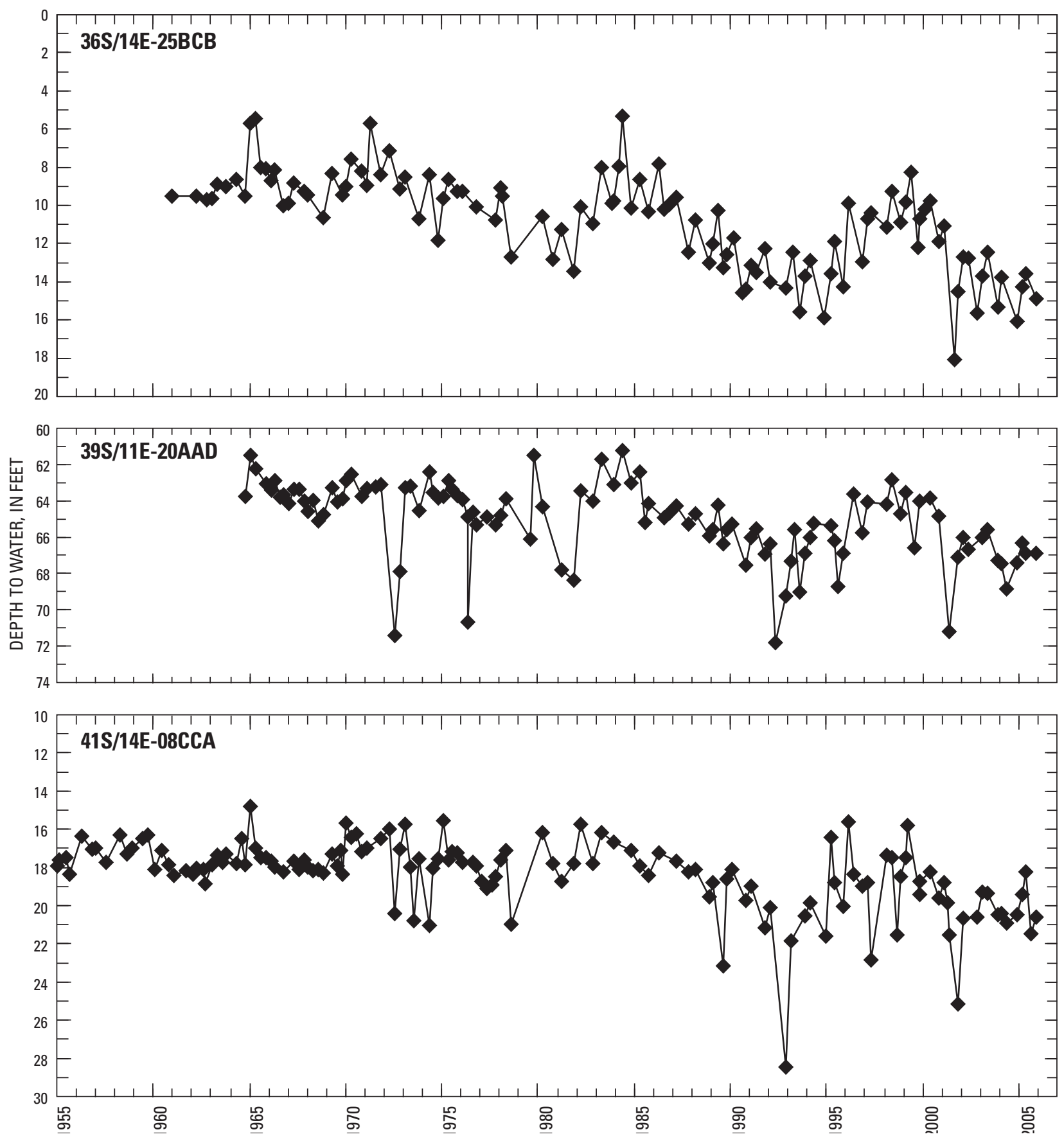

Figure 32. Water-level fluctuations in wells 36S/14E-25BCB near Bly, 39S/11E-20AAD near Bonanza, and 41S/14E08CCA in the southern Langell Valley, Oregon. 
Water levels in two observation wells near the town of Sprague River, 36S/10E-14ACC and 36S/11E-20DCA (fig. 33), have declined over $30 \mathrm{ft}$ since monitoring began in the early 1960s. Leonard and Harris (1974) hypothesized that the relatively steady, and somewhat localized, longterm decline represented a loss of hydraulic head caused by discharge from free-flowing wells. The OWRD later attributed the decline, at least in part, to some wells in the area constructed in a manner that allowed ground water from a the confined basalt aquifer in the lower parts of the wells to flow uphole and into sedimentary units (with lower head) in shallower parts of the well bores (Oregon Water Resources Department, 1987). Borehole geophysical logging has confirmed the interaquifer leakage; however the geologic units receiving the leakage appear to be rhyolitic lavas mapped in the area by Sherrod and Pickthorn (1992) (Mark Norton, Oregon Water Resources Department, unpub. data). For example, geophysical logs for one nearby well show uphole interaquifer flow of about $200 \mathrm{gal} / \mathrm{min}$ into a unit with a relatively high natural gamma signature indicative of silicic material. The driller described the material as "broken lava rock." Water levels in both wells have been more stable since the mid-1990s (fig. 33), likely owing to the ground-water-flow system beginning to reach a new equilibrium.
Water levels in long-term observation well 46N/01E06N01 in Butte Valley were stable from the 1950s to the mid1970s (fig. 34). Since 1975, the water level has declined about $20 \mathrm{ft}$. The trend likely reflects increased pumping stresses during times when precipitation is low, with intermittent times of partial recovery during wet years in the mid-1980s and mid1990s.

An observation well in southern Poe Valley (40S/11E11BAD) shows a series of responses to development from which it has never fully recovered (fig. 35). Most notable is the water-level decline of about $20 \mathrm{ft}$ between 1985 and 1995, a recovery of less than $5 \mathrm{ft}$ between 1995 and 1998, and a decline of about $12 \mathrm{ft}$ since 1998. Another observation well (40S/12E-30DCB) about 3 mi south-southeast of the Poe Valley well, in the area of the Shasta View Irrigation District, has a similar water-level trend where the records overlap from 1994 to present (fig. 35). The total decline in well 40S/12E30DCB since 1998, however, is slightly greater at about $19 \mathrm{ft}$. The similarity of the head fluctuations suggests that the effects of pumping stresses in both areas may migrate across the subbasin boundary.

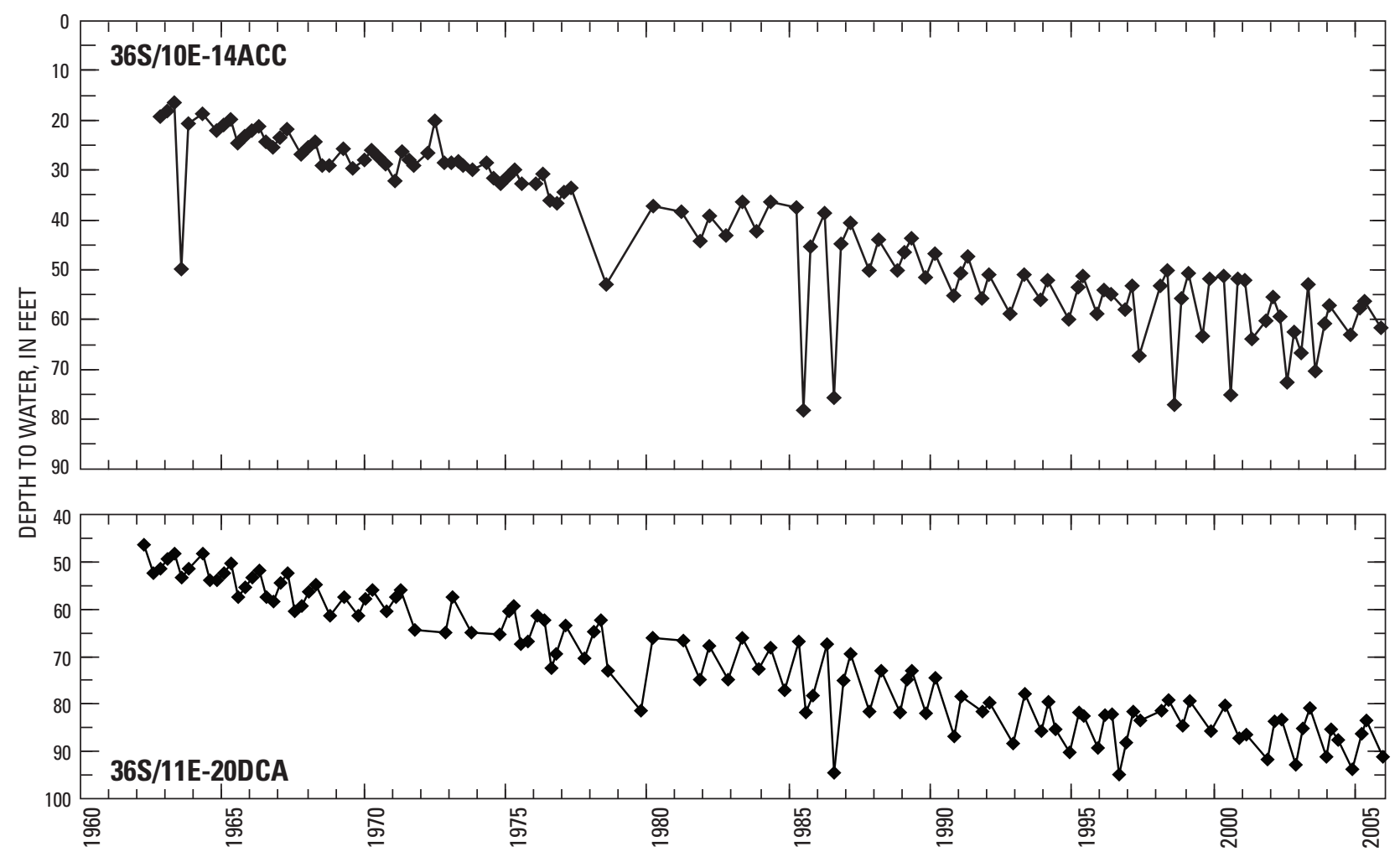

Figure 33. Water-level fluctuations in wells 36S/10E-14ACC and 36S/11E-20DCA in the Sprague River Valley, Oregon. 


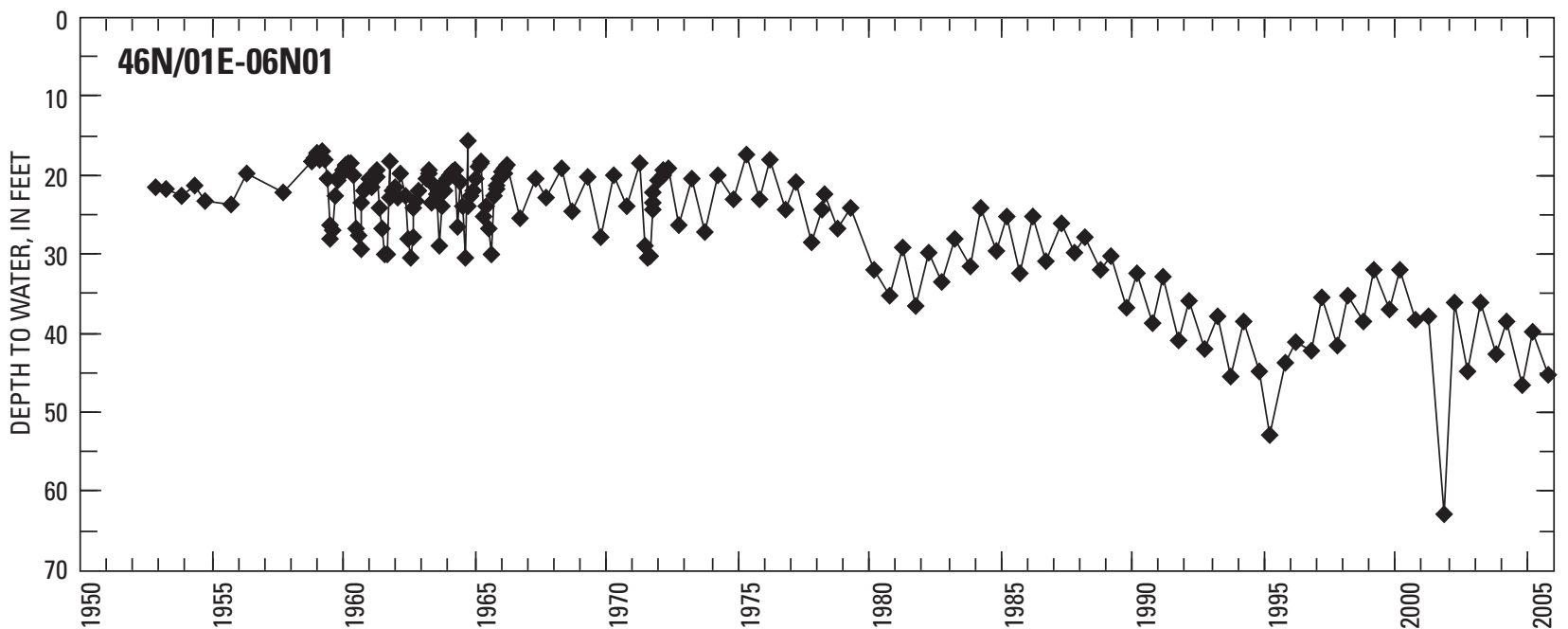

Figure 34. Water-level fluctuations in well 46N/01E-06N01 in Butte Valley, California.
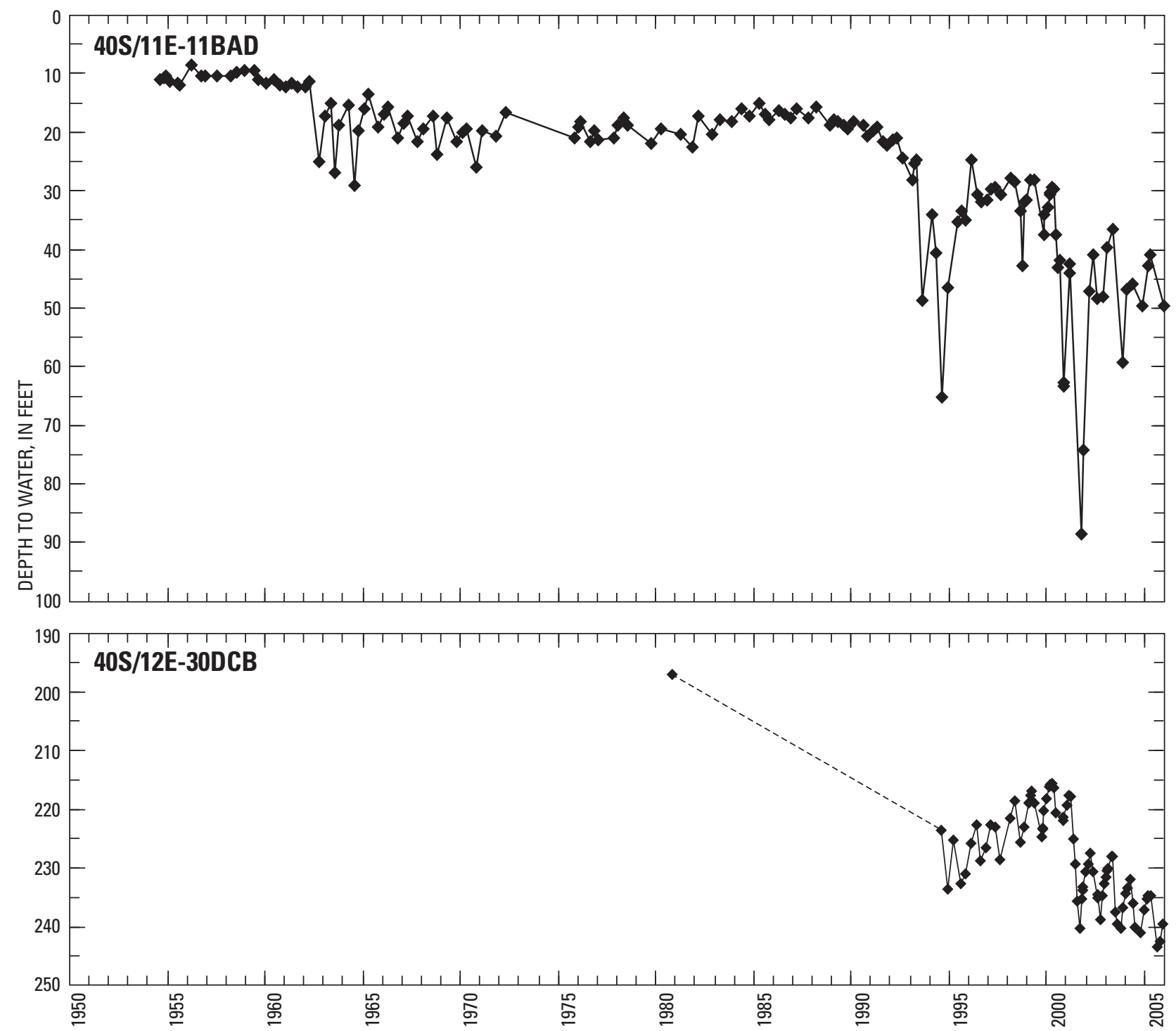

Figure 35. Water-level fluctuations in wells 40S/11E-11BAD in the southern Poe Valley and well 40S/12E-30DCB north of Malin, Oregon. 
Long-term water-level trends in northwest Langell Valley and east of Lorella indicate that pumping stresses in those areas are periodically greater than average (for the area), probably resulting from the occasional use of supplemental ground-water rights. The water level in the observation well in northwest Langell Valley (39S/11E-26ABD) apparently responded to increased pumping during the 1970s, again in the early 1990s, and again starting in 2001 (fig. 36). The groundwater flow system nearly recovered after each of the earlier cycles. In 2005, the water level was about $13 \mathrm{ft}$ below the level measured during 1998, the most recent wet period. A trend similar to that observed in the Langell Valley well, but with a smaller amplitude of fluctuation, is seen in the long-term record at well 39S/12E-35ADD, just east of Lorella (fig. 36). The 2005 water level in the Lorella well was only about $4 \mathrm{ft}$ below the 1998 measurement. Recharge from canal leakage in the area may also be influencing the water-level trend in the Lorella well (Grondin, 2004).

Recent pumping stresses in the Klamath Valley area are reflected in water levels measured in observation well 41S/09E-12AAB (fig. 37). With the exception of a sharp decline in 1970, the water-level trend in the well appears to have been in dynamic equilibrium until 2001. The increased pumping stresses combined with drought contributed to a water-level decline of about $12 \mathrm{ft}$ between 2001 and 2004.

\section{Fluctuations in Hydraulic Head in Response to Recent Increases in Ground-Water Pumping}

Prior to 2001, the ground-water system in most of the upper Klamath Basin was in a state of dynamic equilibrium, under which water levels rose and fell in response to climate cycles and seasonal pumping, but generally without chronic long-term declines. (Water levels in some wells near the town of Sprague River [fig. 33] are an exception.) Historically, water levels declined for several years during droughts, but, with local exceptions, water levels eventually rose to (or nearly to) predrought levels during subsequent multiyear wet periods. Wells generally have been drilled deep enough and pumps set low enough to accommodate these historical water-level fluctuations. Pumping in the upper Klamath Basin increased an estimated 50 percent starting in 2001 in response to changes in water management and a prolonged drought. The ground-water system has responded to the increased pumping with water levels showing acute, seasonal, and long-term effects.

Acute effects occur close to pumping wells, generally within hundreds to thousands of feet. These effects typically are the result of the cone of depression of the pumping well spreading to neighboring wells, resulting in a decline in the static water levels, sometimes referred to as "well interference." These effects typically have a rapid onset and dissipate relatively soon after pumping ends.

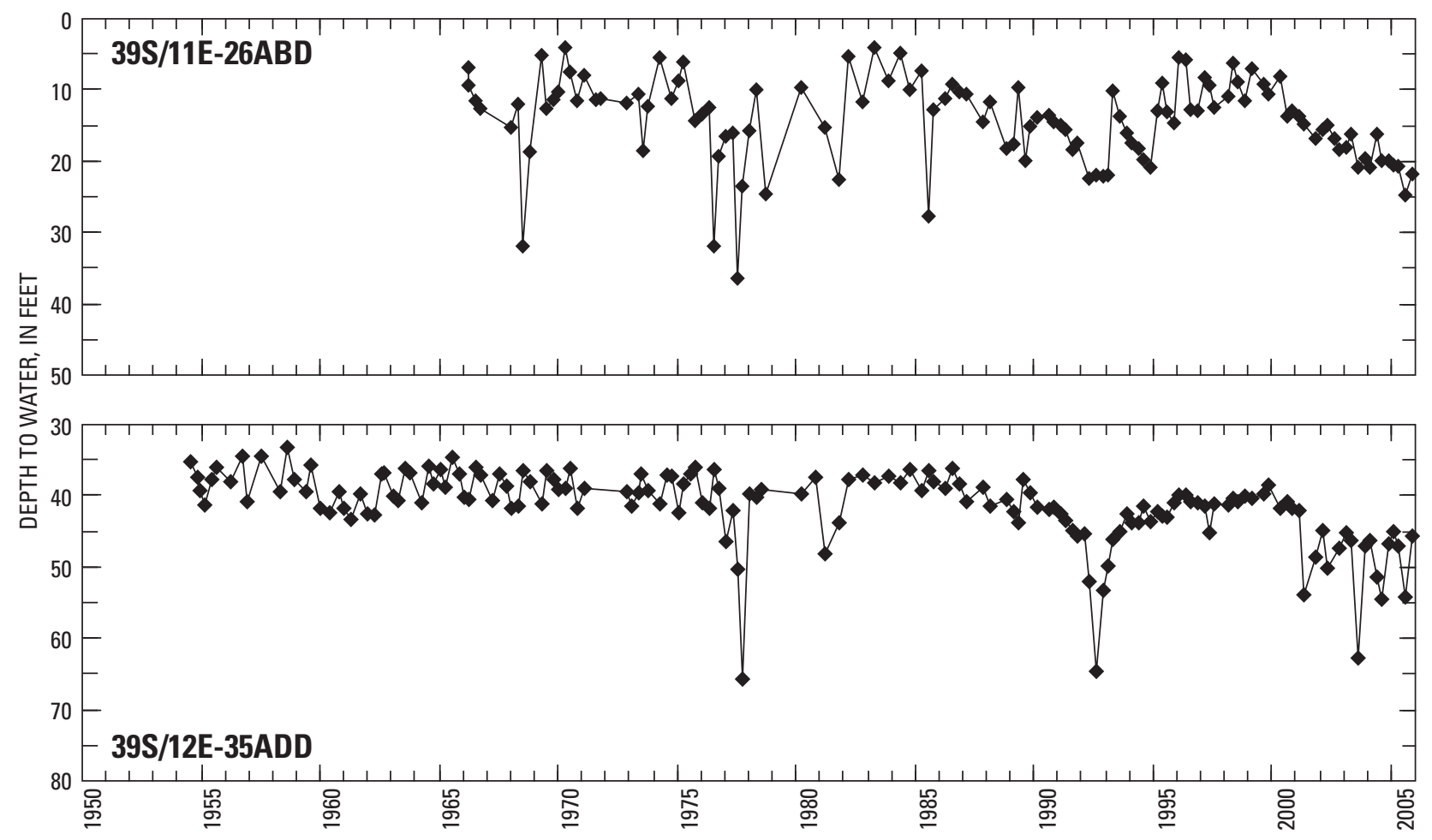

Figure 36. Water-level fluctuations in wells 39S/11E-26ABD and 39S/12E-35ADD in the western Langell Valley, Oregon. 


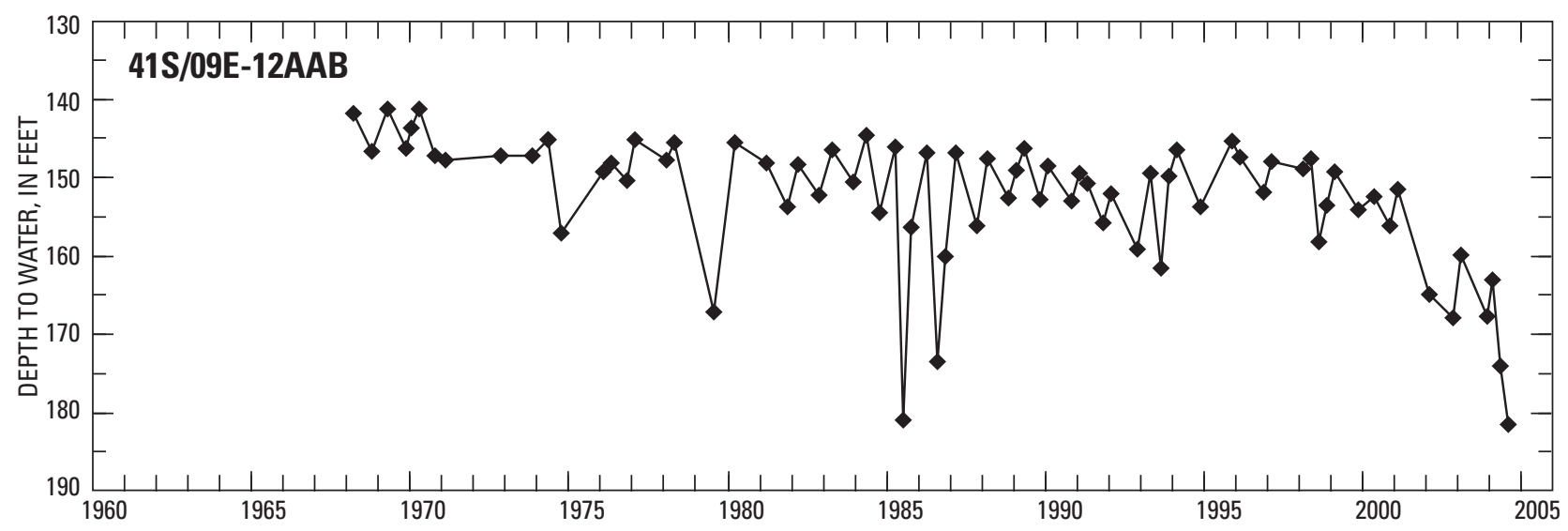

Figure 37. Water-level fluctuations in well 41S/09E-12AAB at the southern end of the Klamath Hills, Oregon.

Seasonal effects reflect the general lowering of the water table over a broad area (several square miles to tens of square miles) in response to the combined seasonal pumping of multiple wells and, in some places, seasonal variations in recharge. These effects typically build up over the irrigation season and largely recover over the following winter.

Figure 38 shows seasonal water-level declines between spring and fall 2004 caused by increased pumping in the basin. Water levels declined more than $10 \mathrm{ft}$ over more than $130 \mathrm{mi}^{2}$ and more than $20 \mathrm{ft}$ over about $20 \mathrm{mi}^{2}$ during the 2004 irrigation season. Declines of 10-20 ft are apparent in an area extending from north of the Klamath Hills, through the Klamath Valley, into the northern and eastern parts of the Tulelake subbasin. Smaller areas in the Klamath Valley and the southeastern part of the Tulelake subbasin show seasonal water-level declines exceeding $20 \mathrm{ft}$ in some wells. Seasonal water-level declines of 1-3 ft were measured in most wells distant from pumping centers. These widespread declines are due to natural seasonal fluctuation, possibly amplified by dispersed pumping and ongoing drought. Although a general decline in water levels was measured during this period, levels in some wells that are hydraulically connected to the shallow aquifer system in the basin-fill sediments rose between spring and fall, ranging from a fraction of a foot to as much as $3 \mathrm{ft}$. This is an annual occurrence entirely due to artificial recharge to the shallow system by canal leakage and deep percolation of irrigation water.
Long-term pumping effects refer to the lowering of the water table for more than a season, often years. Long-term effects can be caused by both climate and pumping stresses. Long-term water level declines typically occur over broad regions, such as an entire subbasin. Long-term decline generally is measured by comparing the spring high water levels each year. Such lowering of the water table has been observed over most of the upper Klamath Basin since about 2000 because of ongoing drought. The only exception is in shallow aquifers in the Klamath Project area, where water levels are maintained by recharge from canal leakage and deep percolation of irrigation water. Long-term declines due to pumping have occurred locally in addition to this droughtrelated decline. Distinguishing pumping related declines from drought related declines in the basin is difficult because of the scarcity of data from previous drought cycles. However, near the town of Tulelake, where long-term water-level data exist, the rate of the year-to-year decline observed in the present drought cycle in well 48N/04E-35L02 appears to be about twice that observed in the most recent previous drought, from the late 1980s through mid-1990s (fig. 39). 


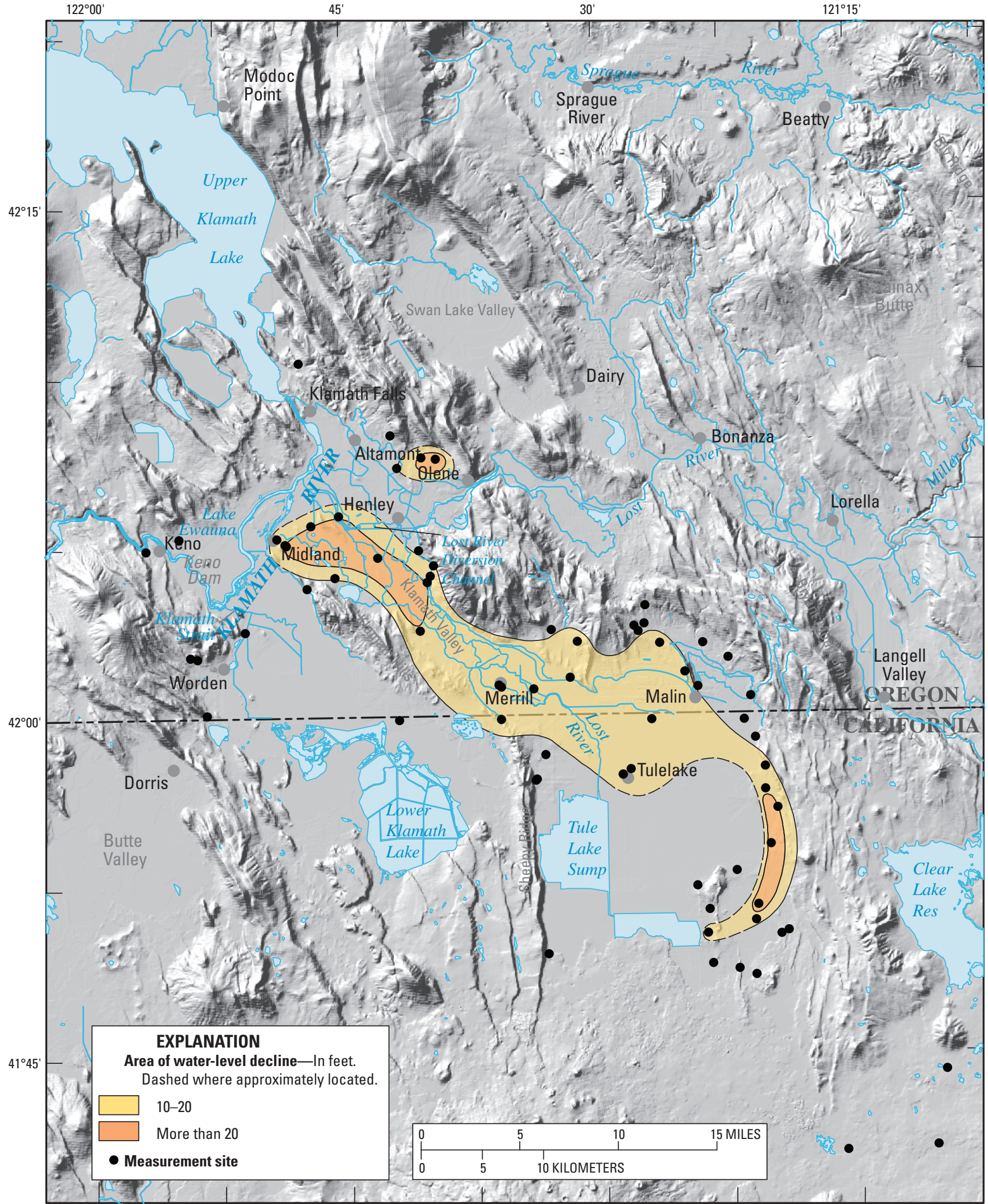

See table of contents for mapping sources

Figure 38. Water-level decline between spring and fall 2004 in the Klamath Valley and Tule Lake areas, upper Klamath Basin, Oregon and California. 


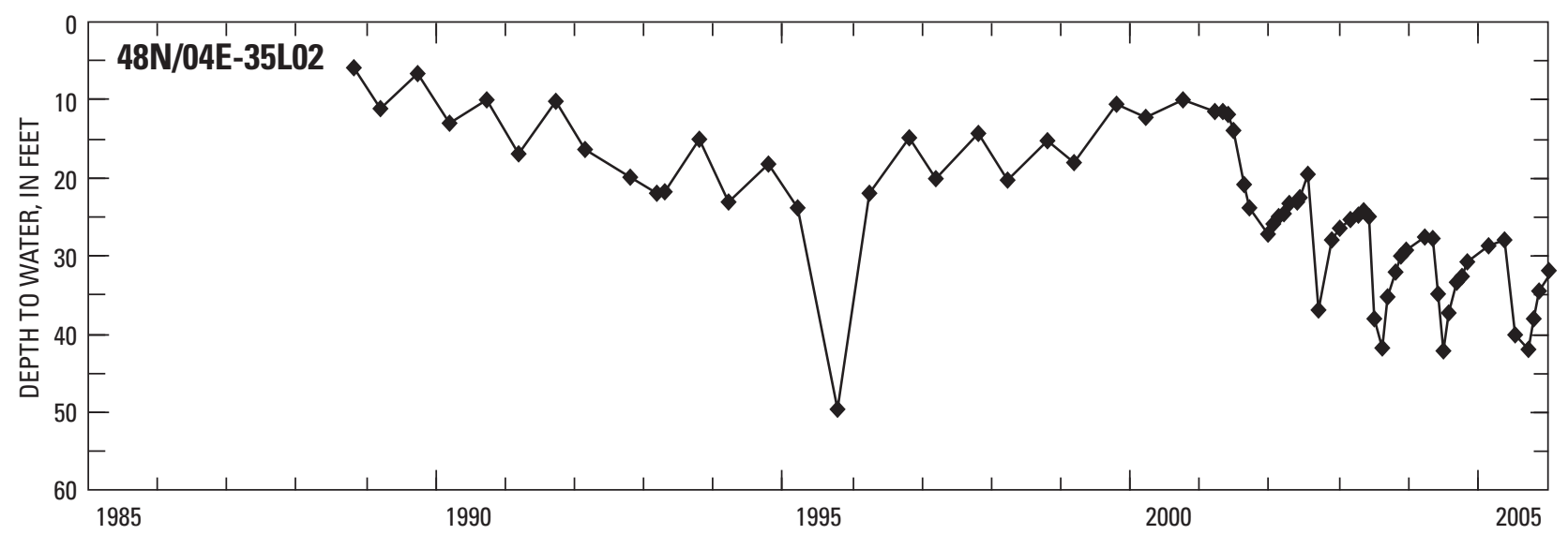

Figure 39. Water-level fluctuations in well 48N/04E-35L02 near the town of Tulelake, California.

The year-to-year water-level declines can be evaluated by observing the changes in water levels between spring 2001 and spring 2004 (fig. 40). Although data are sparse in the northern part of the area, measurements show that over the 3-year period, water levels declined more than $10 \mathrm{ft}$ in deep water-bearing zones (primarily basalt underlying basin-filling sediments) over more than $135 \mathrm{mi}^{2}$ of the Klamath Valley and northern Tule Lake subbasin. Declines exceed $15 \mathrm{ft}$ over an area of about $37 \mathrm{mi}^{2}$ encompassing the State line in the Tule Lake subbasin and extending southward to the town of Tulelake and northward to Malin. Declines of 10-15 ft during this period are common north of Malin. Declines of 5 to $10 \mathrm{ft}$ are common in the southeast part of the Tule Lake subbasin. Levels in three wells on the Modoc Plateau southeast of the Tule Lake subbasin declined 5 to $10 \mathrm{ft}$ (fig. 40). The decline in this southernmost area, where no new pumping has occurred, is somewhat enigmatic, but may indicate that effects are propagating southeastward from pumping centers in the Tule Lake subbasin.

If the post-2000 pumping rates continue in the future, the regional ground-water system possibly will eventually achieve a new state of dynamic equilibrium. This will occur when the depression in the water table is large enough to redirect sufficient regional ground-water flow into the area to offset the increased pumping. At equilibrium, however, the increased discharge in the area of pumping must be offset by decreased discharge elsewhere, likely manifesting itself as a combination of decreased discharge to adjacent basins and decreased discharge to streams, lakes, and wetlands.

Certain details are readily apparent from the recently collected data and existing knowledge of the area. Groundwater pumping is accompanied by declines in water levels that occur at a variety of temporal and spatial scales. The amount of ground water that can be pumped in a period of time will be determined in part by how much drawdown water users and regulatory agencies will tolerate, and in part by how much interference with streams and lakes will be considered acceptable. The drawdown can be easily measured. Where drawdowns acutely affect individual springs, the effects on discharge may be easy to measure. However, where the effects are to larger streams or lakes and represent a small part of the overall flow, they usually are difficult to discriminate from other fluctuations by measurement. Such effects, however, can be calculated using computer models or analytical methods. 


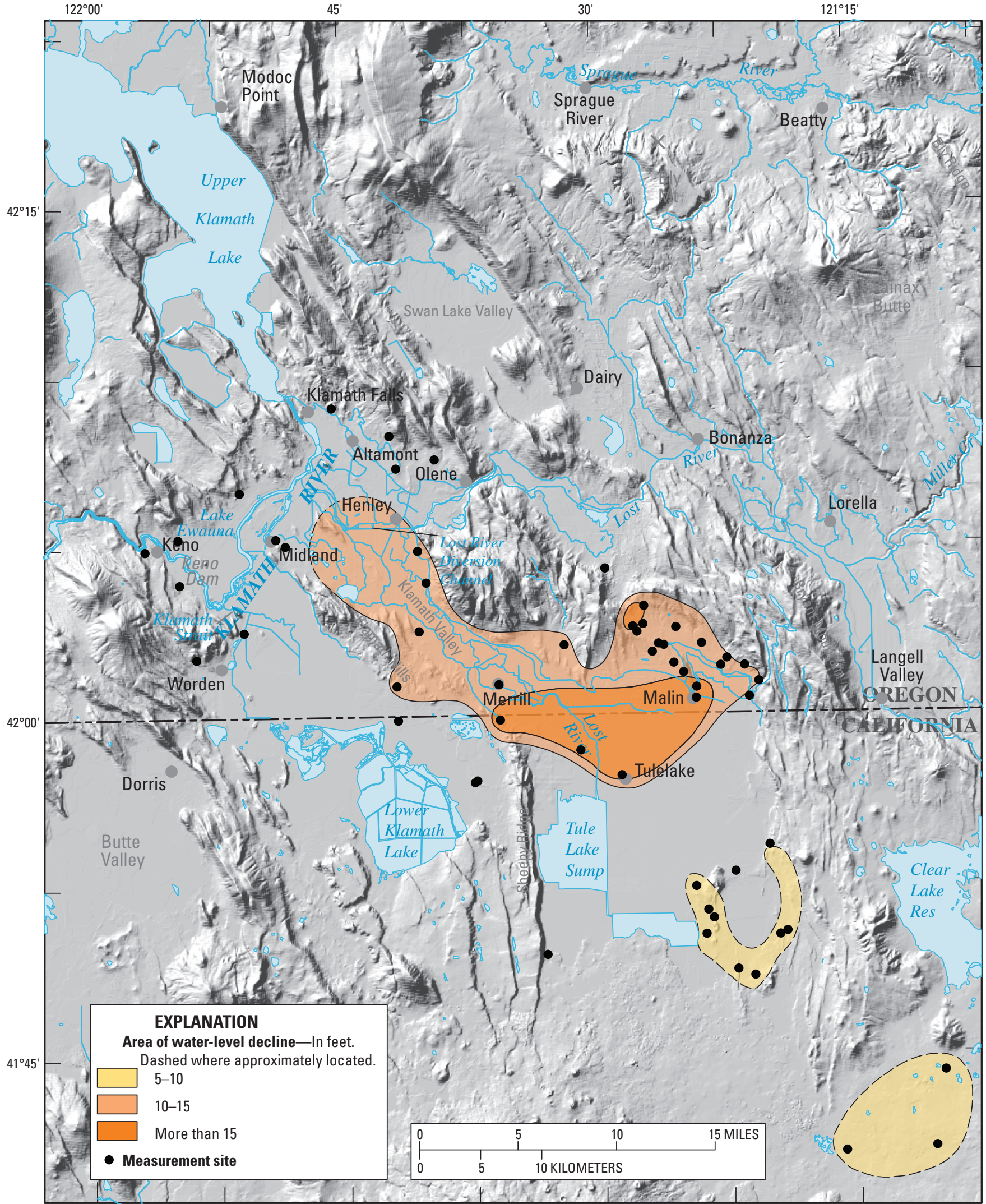

See table of contents for mapping sources

Figure 40. Water-level decline between spring 2001 and spring 2004 in the Klamath Valley and Tule Lake areas, Oregon and California. 


\section{Summary and Discussion}

The demand for water has increased in recent years in the upper Klamath Basin owing to changes in water management resulting from endangered species issues. Problems associated with the increased demand have been exacerbated by drought. As a result, interest has increased in the use of ground water and in understanding how the regional ground-water system can be utilized to prevent future water shortages. Until recently, key aspects of the regional ground-water system were not well known, and information was insufficient to make informed ground-water-management decisions. This report describes part of the results of cooperative efforts by the U.S. Geological Survey and the Oregon Water Resources Department to quantitatively characterize the regional groundwater flow system in the upper Klamath Basin to provide resource managers and basin residents the information needed to make sound resource-management decisions.

The 8,000-square-mile upper Klamath Basin is semiarid, with most of the basin interior receiving less than 20 inches per year of precipitation. Upland areas in the basin are mostly forested, and broad river valleys and lake basins in the basin interior are largely cultivated or in pasture. Irrigated agriculture covers roughly 500,000 acres in the basin. Of this area, roughly 190,000 acres are within the Bureau of Reclamation Klamath Project (this does not include refuge lands in the Project area). Most water for the Klamath Project comes from Upper Klamath Lake. A smaller amount of land in the basin is irrigated using ground water. In 2000, an estimated 59,600 acres were irrigated using ground water.

The upper Klamath Basin spans parts of the Cascade Range and Basin and Range geologic provinces, and is underlain principally by late Tertiary and Quaternary volcanic rocks. The volcanic deposits in the basin are generally permeable and host a substantial regional ground-water system recharged from precipitation in the Cascade Range and uplands within and on the eastern margin of the basin. A prominent system of north to northwest trending faults divides the interior parts of the basin into a series of sedimentfilled structural subbasins. Ground-water flow is controlled by topography, distribution of recharge, the geometry of the stream system, and the geology. The regional geology has been divided into eight hydrogeologic units on the basis of their stratigraphic position and broad hydraulic characteristics. These hydrogeologic units are useful in assessing groundwater potential of specific areas.

Precipitation in the upper Klamath Basin totals about 10 million acre-feet per year. Most of this water returns to the atmosphere at or near where it falls through evapotranspiration. Roughly 2 million acre-feet per year enter the ground-water system. Most of the water that enters the ground-water system discharges elsewhere in the basin to streams, wells, or through evapotranspiration directly from the water table in wetlands.
An estimated 1.8 million acre-feet per year of groundwater discharges to streams. Discharge to streams occurs throughout the basin, but prominent areas of groundwater discharge include the flanks of the Cascade Range, the margins of the Wood River Valley, the area near the confluence of the Williamson and Sprague Rivers (including Spring Creek), the upper Williamson River near Yamsay Mountain, Bonanza Springs on the Lost River, and Klamath River Canyon below John C. Boyle Dam. Much of the ground-water discharge to streams is through major spring complexes. Ground water flows to streams throughout the year, supplying substantial water to streams in the basin. For decades, hydrologists have recognized that much of the water flowing into Upper Klamath Lake originates as ground water that discharges to tributary streams within 12 miles of the lake, or directly to the lake.

Ground-water discharge to streams is not constant, but varies seasonally and from year to year in response to climate cycles. In most large spring complexes, such as the headwaters of Spring Creek or the Wood River, discharge variations due to longer-term, decadal climate cycles are larger than seasonal variations. Discharge to major spring complexes, such as those feeding Wood River and Spring Creek may vary by a factor of 2. Basinwide, climate-driven ground-water discharge variations exceed 450 cubic feet per second, a rate that equates to an annual volume of 326,000 acre-feet.

Ground-water discharge from wells increased gradually from the late 1940s to about 2000, with small increases in the rate of growth related to droughts in the late 1970s and early 1990s. Ground-water pumpage for irrigation in 2000 was about 150,000 acre-feet per year. Ground-water use increased markedly in response to water shortages in 2001 and subsequent water-banking efforts. As a result, ground-water pumpage for irrigation in 2004 was about 226,000 acre-feet per year.

Hydraulic head data from wells and springs shows that ground water flows from principal recharge areas in the Cascade Range and uplands in the basin interior and eastern margins toward discharge areas in the lake basins and stream valleys in the basin interior. In addition, head gradients indicate the potential for flow between structural subbasins in a generally north to south direction. Ground water in the upper Klamath Basin generally flows toward two areas of low hydraulic head: the Klamath River Canyon and the Tule Lake subbasin. Ground water that flows toward the Klamath River Canyon discharges to the river between Keno and John C. Boyle Dam. Some ground water that flows into the Tule Lake subbasin discharges there and is removed by evapotranspiration or pumped to the Lower Klamath Lake subbasin. Head gradient data indicate that some ground water also flows southward out of the Tule Lake subbasin basin toward the Pit River Basin. The amount of southward flow presently is not known. 
Hydraulic head in the upper Klamath Basin fluctuates primarily in response to climate, pumping, canal and irrigation operations, and lake stage. Basinwide, climate exerts the largest influence on water levels. Water levels in upland areas have declined more than 12 feet between 2000 and 2006 in response to drought conditions; however, they are expected to rise again when wet conditions return. Because climatedriven fluctuations affect the entire basin, they have the largest influence on the hydrologic system and are responsible for the large variations in ground-water discharge to streams.

Water level fluctuations in response to pumping are most commonly seasonal, with the water level declining during the irrigation season and recovering more or less fully by the following spring. Prior to 2001, year-to-year water-level declines due to pumping were rare in the upper Klamath Basin. The large localized increase in pumping that began in 2001 has resulted in year-to-year declines in the Klamath Valley and Tule Lake subbasin. The total decline between 2001 and 2004 exceeds 15 feet in parts of these areas and is larger than can be attributed to drought alone. These year-toyear declines have been accompanied by amplified seasonal declines. How long it will take water levels to recover fully after wet climate conditions return and pumping stress is reduced is not known. Data clearly show that pumping stresses can cause measurable head responses over broad parts of the ground-water system.

Irrigation and canal operation also affect water levels, particularly in shallow aquifers. Water levels in these aquifers rise at the beginning of the irrigation season and decline during the off-season. The magnitude of this fluctuation is generally 5 to 10 feet in the main part of the Klamath Project. Water levels in wells near Upper Klamath Lake fluctuate in concert with lake stage.

This study was intended to develop an understanding of the regional ground-water flow system in the upper Klamath Basin to help resource managers and basin residents develop a strategy for managing ground water. Developing a groundwater management strategy for the upper Klamath Basin will require consideration of general characteristics of groundwater flow and characteristics unique to the upper Klamath Basin. Generally, increases in the rate of pumping from a ground-water system will eventually be offset by either increased rates of recharge or (more likely) diminished rates of discharge. Mechanisms whereby ground-water recharge is increased by pumping are rare. In some circumstances, the lowering of hydraulic head caused by pumping could cause increased leakage from streams to the ground-water system. Conditions where this could occur in the upper Klamath Basin are rare. Pumping ground water near basin boundaries can cause the boundaries to shift, effectively capturing recharge from adjacent basins. However, only a fraction of the pumpage would be made up by flow from adjacent basins given likely pumping locations. Diminishment of discharge is the more likely consequence of ground-water extraction. Most of the decrease would be in ground-water discharge to streams, although reductions in discharge to phreatophytes (riparian or wetland vegetation with roots that extend to the water table) and in flows of ground water moving out of the basin in the subsurface could occur as well.

The timing and distribution of the effects of groundwater use are dictated to a large degree by the location of pumping. Pumping very near to discharge areas, such as springs, can diminish the flow of the springs relatively quickly. There have been several instances (with varying amounts of documentation) where ground-water pumping has affected spring discharge in the upper Klamath Basin. Springs affected by pumping in the past include those in Bonanza, elsewhere in the Lost River subbasin, and near Whisky Creek in the Sprague River subbasin.

Ground water is a major component of streamflow in the upper Klamath Basin, and, consequently, ground-water development has the potential to affect streamflow. Because the rate, spatial distribution, and variability of ground-water discharge in the upper Klamath Basin is now well understood, ground-water management strategies can be developed that minimize the effects of ground-water use.

Recently, a considerable effort has been made by various agencies, including the U.S. Geological Survey, the Oregon Water Resources Department, the California Department of Water Resources, and the Bureau of Reclamation, to monitor ground-water levels and ground-water discharge in the upper Klamath Basin. This information has been valuable in developing the present understanding of the regional groundwater system and its response to natural and human-caused stresses. Continued data collection will be important in the future to quantify the response of the ground-water system to stresses.

\section{Acknowledgments}

The authors gratefully acknowledge the support of the residents of the upper Klamath Basin, particularly the many hundreds of individuals who allowed access to property and wells for water-level measurements and monitoring over the course of several years. Our understanding of the groundwater hydrology of the upper Klamath Basin benefited tremendously from many hours of discussions with land owners and scientists working in the basin, who freely shared observations, insights, and valuable data. Particular thanks go to Noel Eaves and Bill Ehorn of the California Department of Water Resources; Jon Hicks, John Rasmussen, and Tom Perry of the Bureau of Reclamation; Jerry Grondin and Ned Gates of the Oregon Water Resources Department; Tim Mayer of the U.S. Fish and Wildlife Service; Mike Stansbury of Water and Energy Services (WESCORP); Steve Luxton of W\&H Pacific; Toni Boyd and John Lund of the Oregon Institute of Technology Geo-Heat Center; and the staffs of the Klamath National Wildlife Refuges Complex and Lava Beds National Monument. Our understanding of the geology of the region 
benefited from discussions with Mike Cummings of Portland State University, Frank Hladky, Margi Jenks, and Ian Madin of the Oregon Department of Geology and Mineral Industries, and Dave Sherrod of the U.S. Geological Survey. Part of the Oregon Water Resources Department contribution to this project was funded through grant assistance from the Bureau of Reclamation Klamath Basin Area Office.

\section{References Cited}

Adam, D.P., Bradbury, J.P., Rieck, H.J., and Sarna-Wojcicki, A.M., 1990, Environmental changes in the Tule Lake basin, Siskiyou and Modoc Counties, California, from 3 to 2 million years before present: U.S. Geological Survey Bulletin 1933, 13 p.

Almy, R. B., 1977, Report on pump test of Hill irrigation well and interference with Modoc Billy Springs, Klamath County, Oregon: Oregon Water Resources Department unpublished internal memorandum, unpaginated.

Anderson, J.R., Hardy, E.E., Roach, J.T., and Witmer, R.E., 1976. A land use and land cover classification system for use with remote sensor data: U.S. Geological Survey Professional Paper 964, 28 p.

Benson, S.M., Sammel, E.A., Solbau, R.D., and Lai, C.H., 1984a, Interpretation of aquifer test data, in Sammel, E.A. ed., Analysis and interpretation of data obtained in tests of the geothermal aquifer at Klamath Falls, Oregon: U.S. Geological Survey Water-Resources Investigations Report 84-4216, p. 5.1-5.55.

Benson, S.M., Janik, C.J., Long, D.C., Solbau, R.D., Lienau, P.J., Culver, G.G., Sammel, E.A., Swanson, S.R., Hart, D.N., Yee, Andrew, White, A.F., Stallard, M.L., Brown, S.P., Wheeler, M.C., Winnett, T.L., Fong, Grace, and Eakin, G.B., 1984b, Data from pumping and injection tests and chemical sampling in the geothermal aquifer at Klamath Falls, Oregon: U.S. Geological Survey Open-File Report 84-146, 101 p.

Boyd, T. G., 1996, Groundwater recharge of the middle Deschutes Basin, Oregon: M.S. Thesis, Portland State University, $86 \mathrm{p}$.

Broad, T.M., and Collins. C.A., 1996, Estimated water-use and general hydrologic conditions for Oregon, 1985-1990: U.S. Geological Survey Water Resources Investigations Report 96-4080, 166 p.

Bureau of Reclamation, 1954, Upper Klamath Basin, OregonCalifornia-A comprehensive departmental report on the development of water and related resources: Sacramento, California, variously paginated, separate appendices.
Bureau of Reclamation, 2005, Natural flow of the upper Klamath River: Bureau of Reclamation Technical Service Center, Denver, Colorado, 77 p. plus attachments.

Burt, Charles, and Freeman, Beau, 2003, Klamath Basin Investigation-Hydrologic assessment of the Upper Klamath Basin-Issues and opportunities-Draft report: San Luis Obispo, California, California Polytechnic State University, Irrigation Training and Research Center (ITRAC), Prepared for the U.S. Bureau of Reclamation, May, 2003, variously paged.

CH2M-Hill, 1992, Groundwater development potential for two proposed Tenaska electrical generating facilities at Malin and Bonanza, Oregon: prepared for Tenaska, Inc., May, 1992 Draft, variously paged.

CH2M-Hill, 1994, Groundwater development potential and hydrogeologic assessment for the Lorella Pumped Storage Project Klamath County, Oregon, CH2M-Hill, Appendix E.2.(a): prepared for Energy Storage Partners, March, 1994, variously paged.

CH2M-Hill, 2002, Deep aquifer testing at the COB Energy Facility water supply well-Water supply supplemental data report-Final report: Portland, Oregon, prepared for Peoples Energy Resources, November, 2002, variously paged.

California Department of Water Resources, 1963, Northeastern counties ground-water investigation, Volume I-Text: State of California Department of Water Resources Bulletin 98, $246 \mathrm{p}$.

California Department of Water Resources, 1998, Butte Valley Wildlife Area well interference investigation: California Department of Water Resources Northern District, December, 1998, 102 p

California State Water Resources Control Board, 1990, California State Water Resources Control Board information pertaining to water rights in California-1990: Accessed at http://www.waterrights.ca.gov/forms/app-geninfo.pdf on 3/2/06, $18 \mathrm{p}$.

Carlson, H.L., and Todd, Rodney, 2003, Effects of the 2001 water allocation decisions on the agricultural landscape and crop production in the Klamath Reclamation Project, in Braunworth, W.S., Jr., Welch, Teresa, and Hathaway, Ron, eds., Water allocation in the Klamath Reclamation Project: an assessment of natural resource, economic, social, and institutional issues with a focus on the upper Klamath Basin, Oregon State University Extension Service Special Report 1037, p. 163-167,

Cooper, R.M., 2002, Determining surface water availability in Oregon: Oregon Water Resources Department Open File Report SW 02-02, 157 p. 
Cooper, R.M., 2004, Natural Flow estimates for streams in the Klamath Basin: Oregon Water Resources Department OpenFile Report SW 04-001 23 p. plus appendixes.

Cuenca, R.H., Nuss, J.L., Martinez-Cob, Antonio, Katul, G.G., and Faci-Gonzalez, J. M., 1992, Oregon crop water use and irrigation requirements: Oregon State University Extension Miscellaneous 8530, 184 p.

Driscoll, F.G., 1986, Groundwater and wells: Johnson Division, St. Paul, 1089 p.

Eaves, J.N., Ehorn, William, Lawrence, Seth, and Ward, Michael, 2002, Upper Klamath Basin Tulelake subbasin hydrogeologic investigation (Draft report): California Department of Water Resources, Northern District, variously paginated.

Fetter, C.W., 1980, Applied hydrogeology: Columbus, Ohio, Charles E. Merrill Publishing Co. 488 p.

Forcella, L.S., 1982, Whisky Creek aquifer test, Klamath County, Oregon: Oregon Water Resources Department unpublished report, 21 p., plus figures and tables.

Freeze, R. A., and Cherry, J. A., 1979, Groundwater: PrenticeHall, Englewood Cliffs, N.J., 604 p.

Gannett, M.W., Lite, K.E., Jr., Morgan, D.S., and Collins, C.A., 2001, Ground-water hydrology of the Upper Deschutes Basin, Oregon: U.S. Geological Survey WaterResources Investigations Report 00-4162, 77 p.

Gates, E.B., 2001, Ground water hydrology of four proposed project areas in the Klamath Basin, Oregon: State of Oregon Water Resources Department Ground Water Open File Report 01-01, 56 p. plus appendices, 4 plates, and 2 maps.

Gay, T.E., Jr., and Aune, Q.A., 1958, Geologic map of California, Olaf P. Jenkins edition, Alturas sheet: California Division of Mines and Geology, 2 sheets, scale 1:250,000.

Golder Associates, Inc., 2002, Groundwater development Lower Klamath National Wildlife Refuge: Redmond, Washington, Golder Associates, Inc., prepared for Water and Energy Services (WESCORP), Mercer Island, Washington, 993-1683-004.002 (0219mk1.doc), February 19, 2002, 20 p. plus tables, figures, and appendices.

Grondin, G.H., 2004, Ground water in the eastern Lost River sub-basin, Langell, Yonna, Swan Lake, and Poe Valleys of southeastern Klamath County, Oregon: Oregon Water Resources Department Ground-Water Report 41, 171 p., 42 appendices, 5 plates.

Hammond, P.E., 1983, Volcanic formations along the Klamath River near Copco Lake, Siskiyou County: California Geology, v. 36. no. 5, p. 99-109.
Heath, R.C., 1983, Basic ground-water hydrology: U.S. Geological Survey Water-Supply Paper 2220, 84 p.

Hubbard, L.E., Herrett, T.A., Kraus, R.L., Ruppert, G.P., and Courte, M.L., 1993,Water resources data, Oregon, water year 1992: U.S. Geological Survey Water-Data Report OR-92-1, 474 p.

Hubbard, L.E., Herrett, T.A., Kraus, R.L., Ruppert, G.P., and Courte, M.L., 1994, Water resources data, Oregon, water year 1993: U.S. Geological Survey Water-Data Report OR93-1, $498 \mathrm{p}$.

Hubbard, L.H., 1970, Water budget of Upper Klamath Lake southwestern Oregon: U.S Geological Survey Hydrologic Investigations Atlas HA-351.

King, L.D., Hellickson, M.L., Schmisseur, W.E., and Shearer, M.N., 1978, Projected energy and water consumption of Pacific Northwest irrigation systems: Corvallis, Oregon, Prepared by Oregon State University for U.S. Department of Energy through Battelle Pacific Northwest Laboratories, PNL-RAP-33, 112 p.

Konrad, C.P., Drost, B.W., and Wagner, R.J., 2003, Hydrogeology of the unconsolidated sediments, water quality, and ground-water/surface-water exchanges in the Methow River Basin, Okanogan County, Washington: U.S. Geological Survey Water-Resources Investigations Report 03-4244, 137 p.

La Marche, J.L., 2001, Water imports and exports between the Rogue and upper Klamath Basins: Unpublished report prepared for the Klamath Alternative Dispute Resolution Hydrology Steering Committee, 7 p.

La Marche, 2002, Big Springs hydrologic field study: Oregon Water Resources Department unpublished report, September 2, 2002, 21 p.

La Rue, E.C., 1922, Klamath River and its utilization: Report to the Office of the State Engineer, Salem, Oregon, 204 p.

Leonard, A.R., and Harris, A.B., 1974, Ground water in selected areas in the Klamath Basin, Oregon: Oregon State Engineer Ground Water Report No. 21, 104 p.

Loy, W.G., Allan, Stuart, Buckley, Aileen, and Meacham, Jim, 2001, Atlas of Oregon: University of Oregon Press, Eugene, $320 \mathrm{p}$.

MacLeod, N.L., and Sherrod, D.R., 1992, Reconnaissance geologic map of the west half of the Crescent $1^{\circ}$ by $2^{\circ}$ quadrangle, central Oregon, U.S. Geological Survey Miscellaneous Investigations Series Map I-2215.

Meinzer, O.E., 1927, Large springs in the United States: U.S. Geological Survey Water-Supply Paper 557, 94 p. 
Mertzman, S.A., Jr., 2000, K-Ar results from the southern Oregon-northern California Cascade Range: Oregon Geology, v. 62, no. 4, p. 99-122.

Moench, A.F., 1984, Double-porosity models for a fissured groundwater reservoir with fracture skin: Water Resources Research, v. 20, n. 7, p. 831-846.

National Marine Fisheries Service, 2002, Biological opinionKlamath project operations: http://swr.nmfs.noaa.gov/psd/ klamath/KpopBO2002finalMay31.PDF, accessed January 5, 2007.

Natural Resources Conservation Service, 2004, Summary of the upper Klamath Basin rapid subbasin assessment of private lands: U.S. Department of Agriculture, Natural Resources Conservation Service, variously paginated.

Newcomb, R.C., and Hart, D.H., 1958, Preliminary report on the ground water resources of the Klamath River Basin, Oregon: U.S. Geological Survey Open-File Report [unnumbered], $248 \mathrm{p}$.

Northwest Geophysical Associates, Inc., 2002, Gravity survey groundwater investigation Lower Klamath Lake Basin Klamath County, Oregon: Corvallis, Oregon, Northwest Geophysical Associates, Inc., prepared for Klamath Drainage District, May, 2002, 13 p. plus 11 sheets.

Oregon Blue Book: http://bluebook.state.or.us/, accessed February 27, 2006

Oregon State University PRISM Group, 2006, PRISM Group data website: www.ocs.oregonstate.edu/prism, accessed 9/2006.

Oregon Water Resources Department, 1987, Information Report-Well reconstruction in the Whisky Creek area, near Sprague River: Memorandum from the Director to the Water Resources Commission regarding Agenda Item L, June 5, 1987 Water Resources Commission Meeting, 6 p.

Orr, E.L., Orr, W.N., and Baldwin, E.M., 1992, Geology of Oregon: Kendall/Hunt Publishing Co., 254 p.

Palmer, P.C., Gannett, M.W., and Hinkle, S.R., 2007, Isotopic characterization of three groundwater recharge sources and inferences for selected aquifers in the upper Klamath Basin of Oregon and California, USA: Journal of Hydrology, v. 336, p. 17-29.

Priestly, C.H.B., and Taylor, R.B., 1972, On the assessment of surface heat flux and evaporation using large-scale parameters: Monthly Weather Review, v. 100, p. 81-92.

Risley, J.C., and Gannett, M.W., 2006, An evaluation and review of water-use estimates and flow data for the Lower Klamath and Tule Lake National Wildlife Refuges, Oregon and California: U.S. Geological Survey Scientific Investigations Report 2006-5036, 18.
Risley, J.C., Gannett, M.W., Lea, J.K., and Roehl, E.A., Jr., 2005, An analysis of statistical methods for seasonal flow forecasting in the upper Klamath Basin of Oregon and California: U.S. Geological Survey Scientific Investigations Report 2005-5177, 44 p.

Russell, R.J., 1928, Basin range structure and stratigraphy of the Warner Range, northeastern California: University of California, Bulletin of the Department of Geological Sciences, v. 17, n. 11, p. 387-496.

Sammel, E.A., and Peterson, D.L., 1976, Hydrologic reconnaissance of the geothermal area near Klamath Falls, Oregon, with a section on Preliminary interpretation of geophysical data: U.S. Geological Survey Water-Resources Investigations Report 76-127, 137 p.

Sherrod, D.R., 1991, Geologic map of a part of the Cascade Range between latitudes $43^{\circ}-44^{\circ}$, central, Oregon: U.S. Geological Survey Map I-1891, 14 p., scale 1:125,000, 1 sheet.

Sherrod, D.R., and Pickthorn, L.G., 1992, Geologic map of the west half of the Klamath Falls $1^{\circ}$ by $2^{\circ}$ Quadrangle, southcentral Oregon: U.S. Geological Survey Miscellaneous Investigations Series, Map I-2182, scale 1:250,000, 1 sheet.

Sherrod, D.R., and Smith, J.G., 2000, Geologic map of upper Eocene to Holocene volcanic and related rocks of the Cascade Range Oregon: U.S. Geological Survey Miscellaneous Investigations Map I-2569, scale 1:500,000.

Siskiyou County, 2003, Annual report of estimated crop and livestock production, year ending December 31, 2003: Siskiyou County Department of Agriculture, unpaginated.

Smith, J.G., Page, N.J., Johnson, M.G., Moring, B.C., and Gray, Floyd, 1982, Preliminary geologic map of the Medford $1^{\circ}$ by $2^{\circ}$ quadrangle, Oregon and California: U.S. Geological Survey Open-File Report 82-955, scale $1: 250,000,1$ sheet.

Snyder, D.T., and Morace, J.L., 1997, Nitrogen and phosphorous loading from drained wetlands adjacent to Upper Klamath and Agency Lakes, Oregon: U.S. Geological Survey Water-Resources Investigations Report 97-4059, 67p.

Stonestrom, D.A., Prudic, D.E., Laczniak, R.J., Akstin, K.C., Boyd, R.A., and Henkelman, K.K., 2003, estimates of deep percolation beneath native vegetation, irrigated fields, and the Amargosa-River channel, Amargosa Desert, Nye County, Nevada: U.S. Geological Survey Open File Report 03-14, 83 p. 
Theis, C.V., 1935, The relation between the lowering of the piezometric surface and the rate and duration of discharge of a well using ground-water storage: American Geophysical Union Transactions, $16^{\text {th }}$ Annual Meeting, part 2, p. $518-524$.

U.S. Department of Agriculture, 2004, Statistics by stateOregon: http://www.nass.usda.gov/Statistics_by_State/ Oregon, accessed January 5, 2007.

U.S. Geological Survey, 1956, Surface water supply of the United States, 1954, Part 11, Pacific slope basins in California: U.S. Geological Survey Water-Supply Paper 1345,574 p.

U.S. Geological Survey, 1960a, Surface water supply of the United States, 1959, Part 11, Pacific slope basins in California: U.S. Geological Survey Water-Supply Paper $1635,748 \mathrm{p}$.

U.S. Geological Survey, 1960b, Compilation of records of surface waters of the United States through September 1950. Part 11-A, Pacific slope basins in California, except Central Valley: U.S. Geological Survey Water-Supply Paper 1315-B, p. 471-864.

U.S. Geological Survey, [various dates], Surface water supply of the United States, Pacific slope basins in California: U.S. Geological Survey Water-Supply Paper, various parts.

Vance, J.A., 1984, The lower Western Cascades Volcanic Group in northern California, in Nilsen, T.H. ed., Geology of the Upper Cretaceous Hornbrook Formation, Oregon and California: Society of Economic Paleontologists and Mineralogists, Pacific Section, Field Trip Guidebook v. 42, p. 195-196.

Veen, C.A., 1981, Gravity anomalies and their structural implications for southern Oregon Cascade Mountains and adjoining Basin and Range province: Corvallis, Oregon, Oregon State University, M.S. thesis, 86 p.

Wagner, D.L., and Saucedo, G.J., compilers, 1987, Geologic map of the Weed Quadrangle: California Division of Mines and Geology Regional Geologic Map Series Map No. 4A (Geology), 15 p., scale 1:250,000, 4 sheets.

Walker, G.W., 1963, Reconnaissance geologic map of the eastern half of the Klamath Falls (AMS) quadrangle, Lake and Klamath counties, Oregon: U.S. Geological Survey Mineral Investigations Field Studies Map MF-260, scale $1: 250,000,1$ sheet.
Watershed Sciences, 2002, Aerial survey in the Klamath and Lost River Basins-Thermal infrared and color videography, Watershed Sciences, LLC, Corvallis, OR, 29 p., plus appendices.

Weber, Bruce, and Sorte, Bruce, 2003, The upper Klamath Basin economy and the role of agriculture: in Braunworth, W.S., Jr., Welch, Teresa, and Hathaway, Ron, eds. Water allocation in the Klamath Reclamation Project: an assessment of natural resource, economic, social, and institutional issues with a focus on the upper Klamath Basin, Oregon State University Extension Service Special Report 1037, p. 213-229.

Weddell, B.J., 2000, Relationship between flows in the Klamath River and Lower Klamath Lake prior to 1910: Report to U.S. Fish and Wildlife Service Klamath Basin Refuges, Tulelake California, $10 \mathrm{p}$.

Weeks, E.P., 2005, Hydrologic properties of coal-beds in the powder River Basin, Montana. II. Aquifer test analysis: Journal of Hydrology, v. 308, p. 242-257.

WESCORP (and Golder Associates), 2003, Lower Klamath NWR groundwater program-2002 groundwater development report-U.S. Fish and Wildlife Service: Mercer Island, Washington, WESCORP (Water and Energy Services Corporation), January, 2003, variously paged.

Western Regional Climate Center, 2006, Historical climate data: http://www.wrcc.dri.edu, accessed 9/2006.

William E. Nork, Inc., 1992, Analysis of pumping tests on OIT Injection Well No. 2: Prepared for Oregon Institute of Technology by William E. Nork, Inc., Reno, Report 92-421 [PSC-P 58777], 9 p. plus figures and tables.

Wood, P.R., 1960, Geology and ground-water features of the Butte Valley region, Siskiyou County, California: U.S. Geological Survey Water-Supply Paper 1491, 150 p.

Zwart, M.J., and Gates, E.B., 2002, Results of a long-term aquifer test at the Ron McVay irrigation well, Klamath County, Oregon: State of Oregon Water Resources Department Ground Water Open File Report 02-004, 35 p. plus 3 appendices. 
Ground-Water Hydrology of the Upper Klamath Basin, Oregon and California

This page intentionally left blank. 


\section{Appendix A. Landsat Analysis Methods}

The imagery classification was based on two levels of resolution: (1) a generalized nonirrigated level that consisted of four Anderson Level I/II classes: ice and snow, evergreen forest, water, and shrub lands that represented a combination of bare soil, rock, sagebrush and other nonirrigated vegetation (Anderson and others, 1976); and (2) irrigated lands clustered into five vegetative classes based on their spectral similarity and potential crop water needs. These classes were labeled alfalfa and irrigated grasses, small grains, onions-garlic, potatoes-corn, and strawberries. Although it would have been desirable, identification of individual crop types proved to be impossible because of the lack of unique spectral signatures (Paul Seevers, EROS Data Center, written commun., 2000). The use of three satellite images from different times during the growing season increased the probability that certain croptypes could be distinguished based on the development of their spectral signatures. To aid in the classification of the imagery, field work was conducted to map directly crop types in areas totaling about 17,000 acres. A variety of representative landcover types were observed, including native trees, pasture and most of the agricultural crops. Most data were collected in mid-July. Data on crop type and height, percentage of crop cover, sprinkler type, and other parameters also were collected.

The three images were processed in succession. The May 21, 2000, scene (from Landsat 5) showed full canopy cover of the perennial crops such as alfalfa, irrigated grasses, and any winter wheat that may have been planted the previous fall. The timing of the scene put it before any annual row crops had enough growth to show a vegetative signature. Areas with vigorous growth in the May scene served to mask over the same areas in the August scene. This step reduced the amount of data in the August scene that required analysis. The irrigation district boundaries were used to segregate irrigated areas outside of the Klamath Project. The August 1 scene (from Landsat 7) revealed the full canopy of the annual row crops planted during the spring. The September 18 scene (also from Landsat 7) was used to show any crops that might have a vigorous vegetative signature beyond the harvest dates of the small grains.

A review was performed on the results of the final landcover classification by creating an error matrix to evaluate how well the classification of the imagery matched what was actually mapped on the ground. The review looked at how accurately the classification identified specific crop-types and how accurately the classification did with respect to all irrigated crop-classes. To do this, the new land-cover map created from the classified Landsat imagery was converted to a polygon dataset, with each polygon being 30 meters, the resolution of the original imagery. Each polygon contained a code for crop class determined by the classification process. The ground reference boundaries were then used to clip out the same areas in the classified land cover. The clipped landcover polygons were then evaluated by crop class against the ground reference. For example, if a ground reference area was identified as alfalfa, then the same area was compared in the land cover. The results of the review showed that largeacreage crops such as alfalfa had a correct classification ratio of about 64 percent. However, if all irrigated crop classes were included then the accuracy of identifying irrigated lands within that area increased to about 73 percent. For crops grown on smaller fields, the accuracy of the classification to identify specific crop class decreased to a range of 20 to 30 percent. If all irrigated lands were included then the accuracy increased to the 50 to 70 percent range. Sugar beet fields for example, were correctly classified 34 percent of the time, but if all irrigated lands for the same area were included then the accuracy increased to 62 percent. All mint and strawberry fields were located during the ground truth and were included in the final classification. 


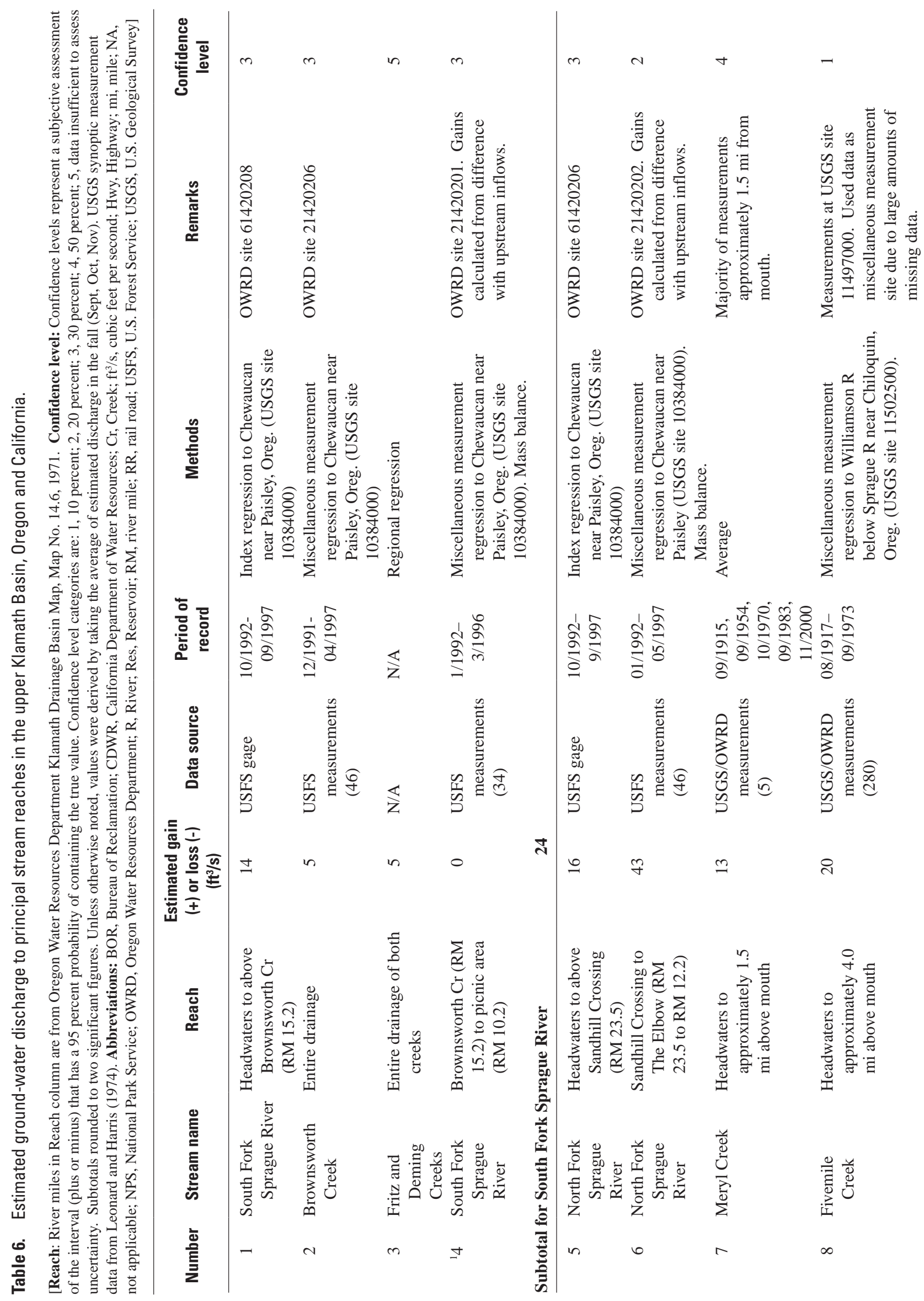




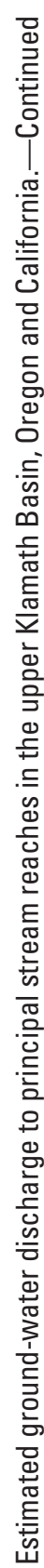
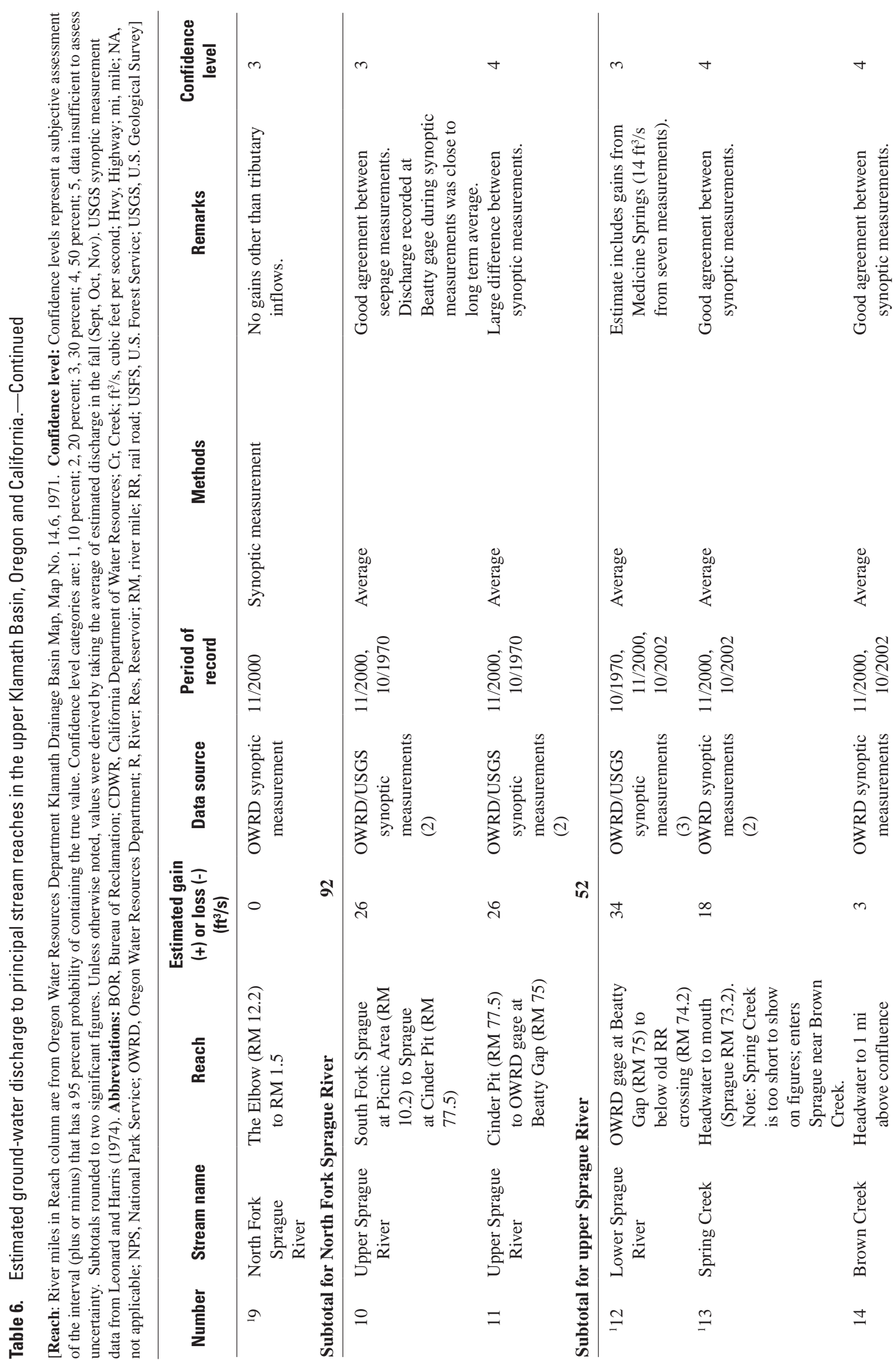

里

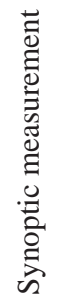

흠흔

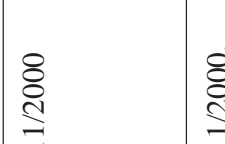

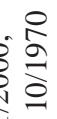

¿ํำ

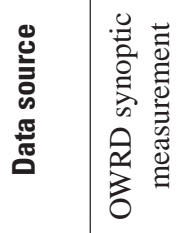

言竑

递 0

$\frac{2}{ \pm}$

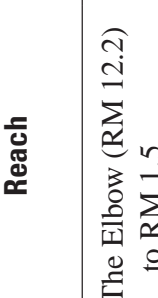

$\exists$

离

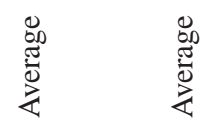

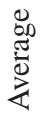

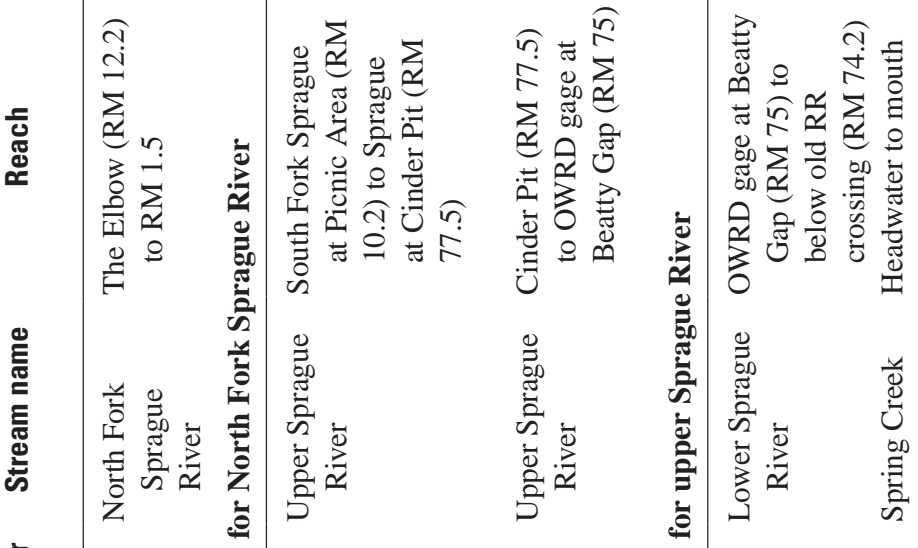

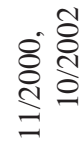

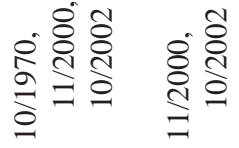

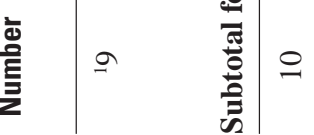

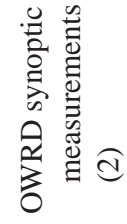

ก

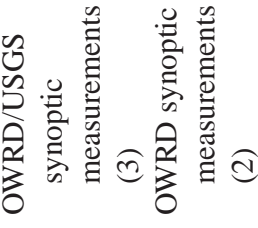

$m$

i

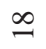

$=\quad \frac{\pi}{8} \cong$

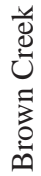

$\pm$ 


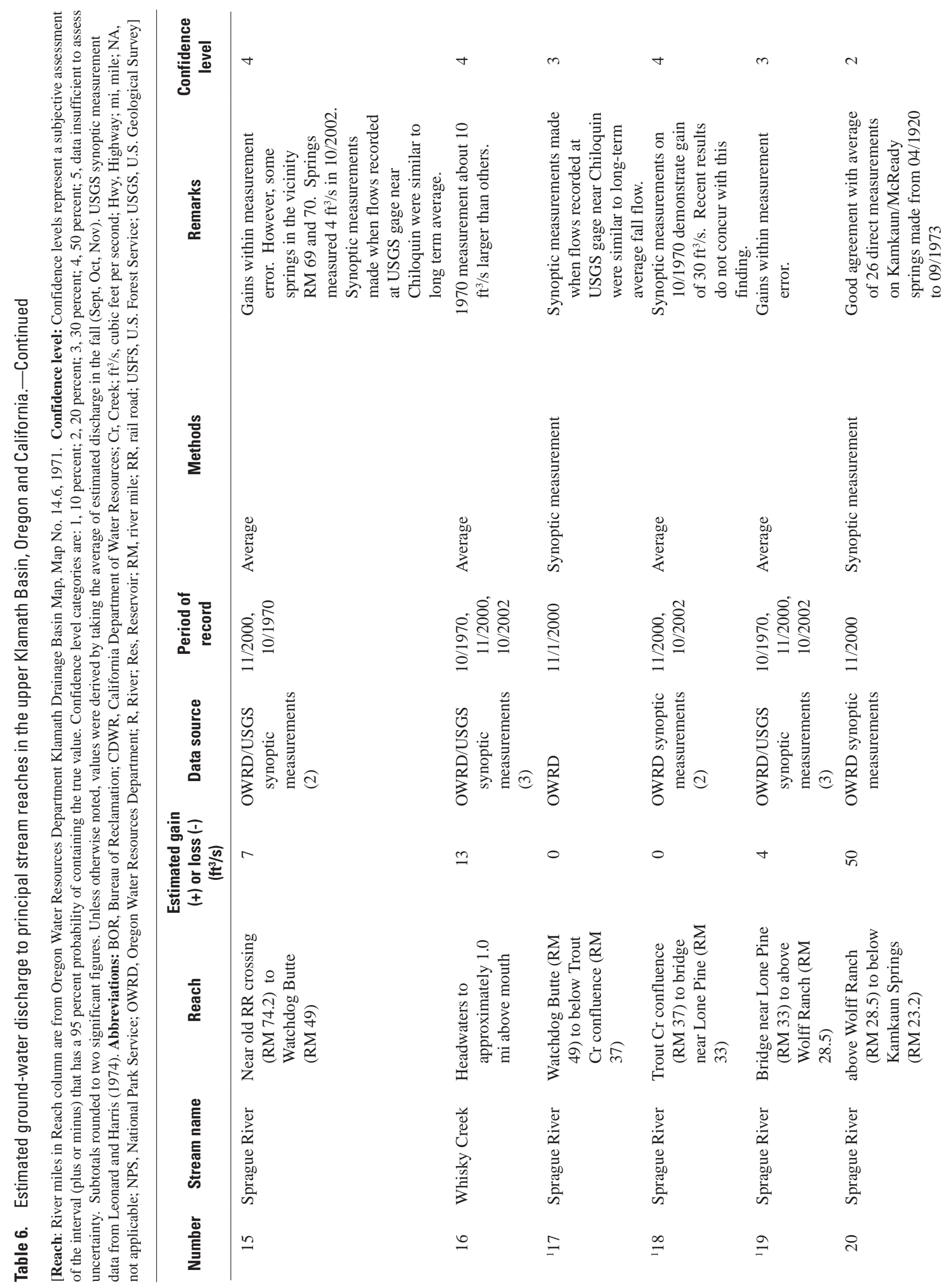


要

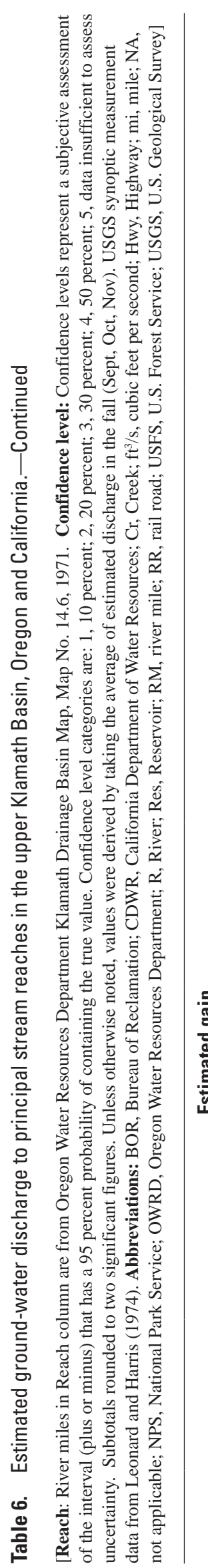

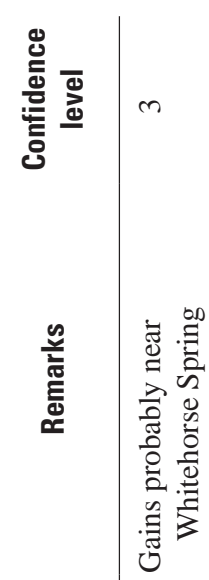
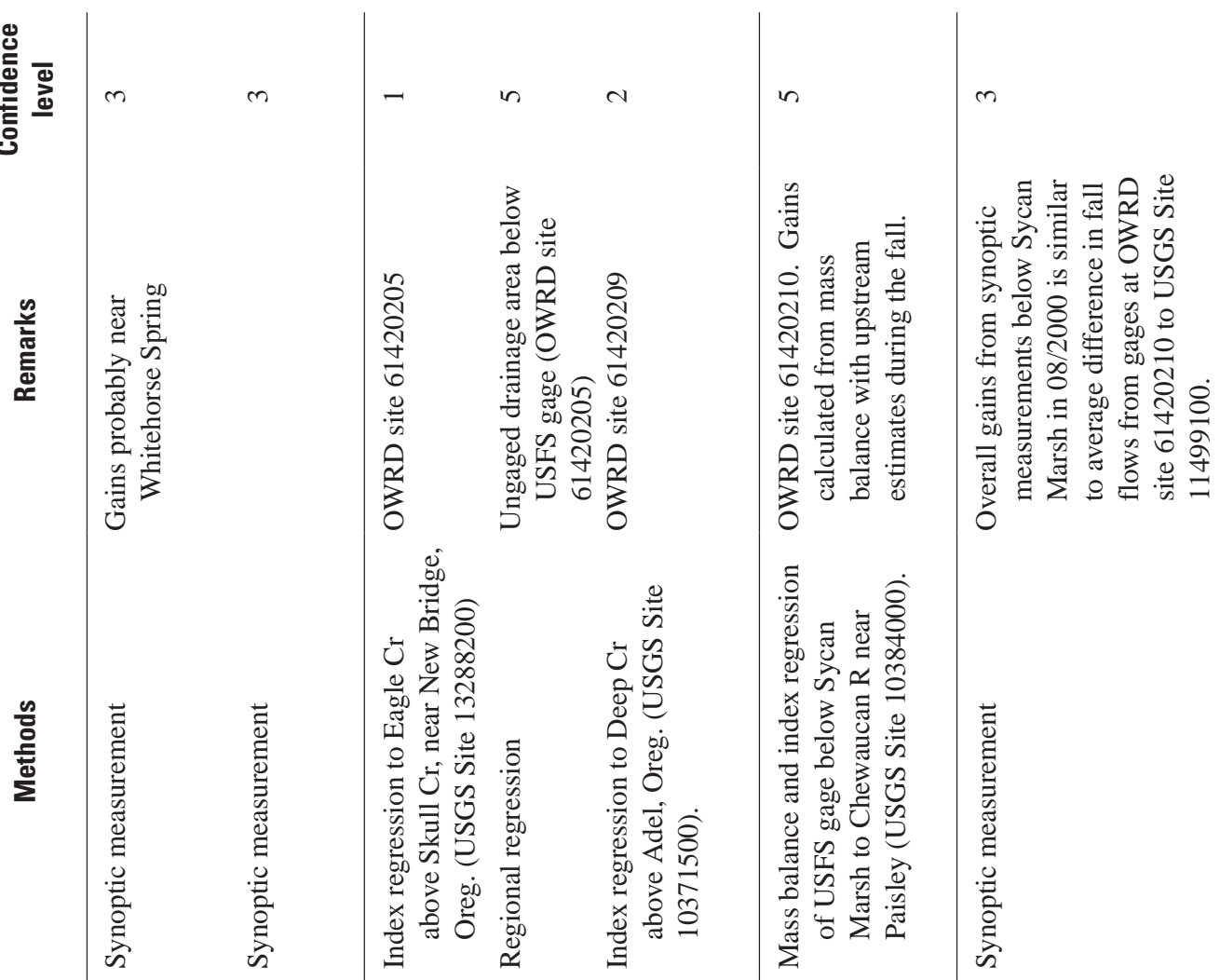

흠 혼
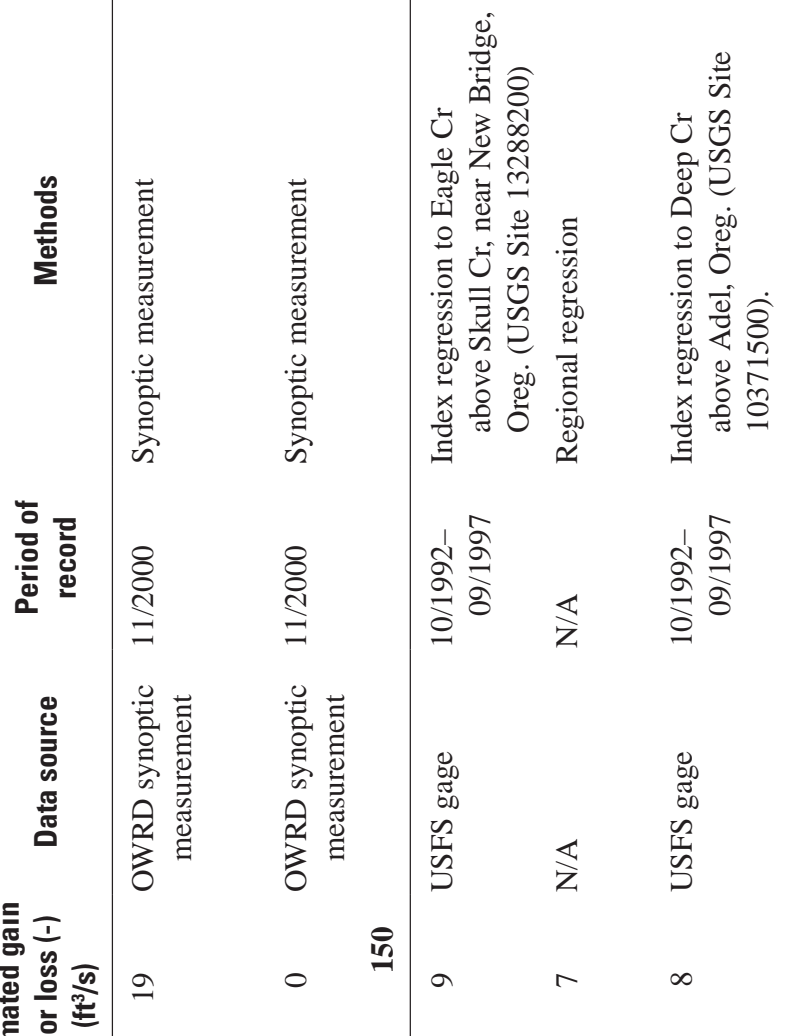

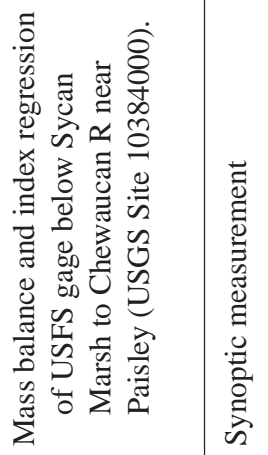

王

$\sum$

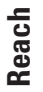

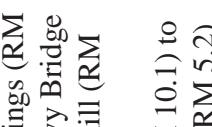

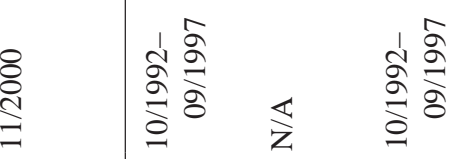

๙ั

$\approx$

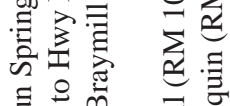

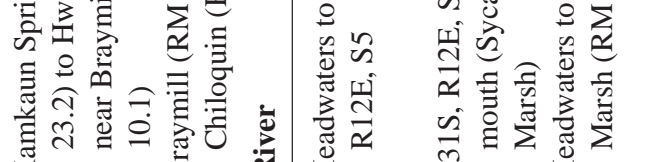

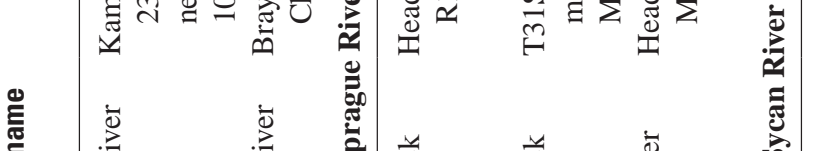

产

产

衰 ন

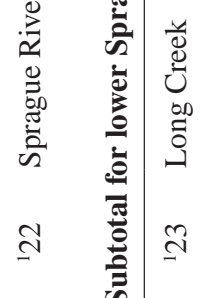

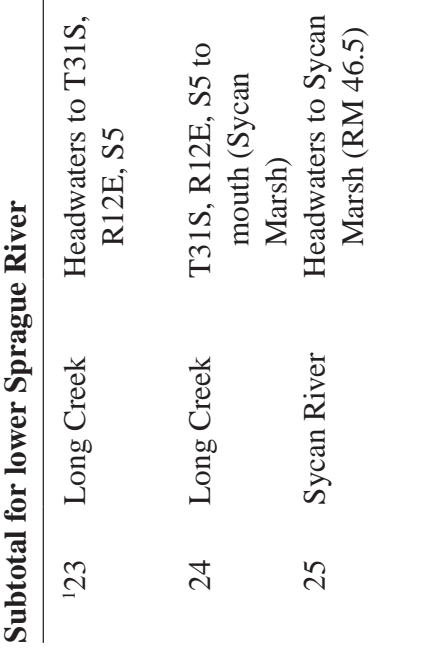

ส

(1)

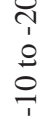

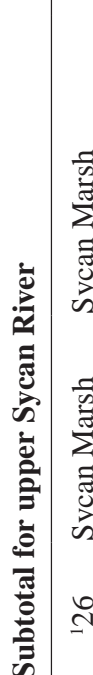

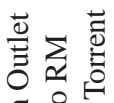

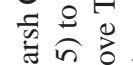

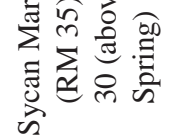

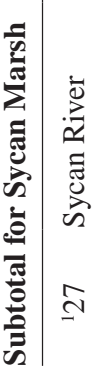




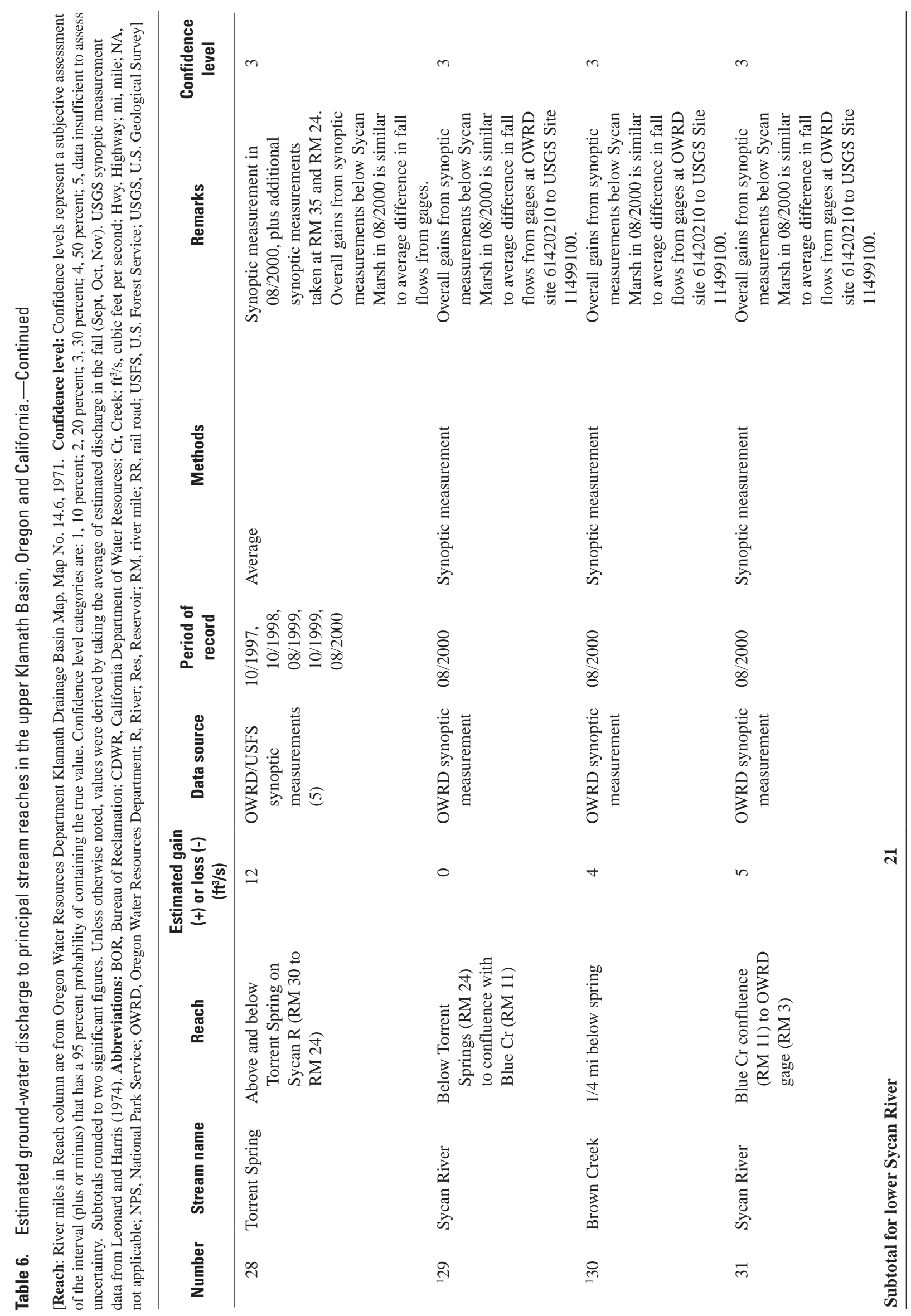


恶

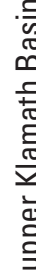

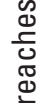

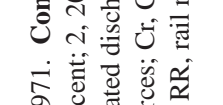
○远苛

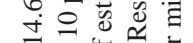

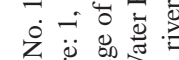

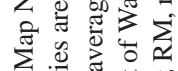

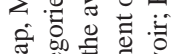
$\sum \overbrace{0}^{0}$ क

एँ एँ

응

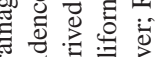

ด

च ن

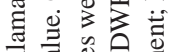

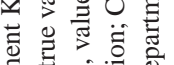

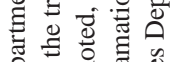

ปิ

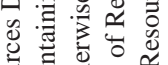

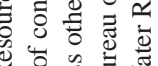

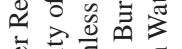

武

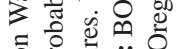

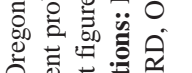

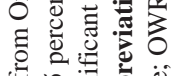

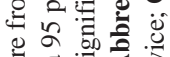

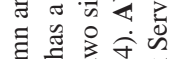

吾吉吉品

ป气

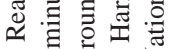

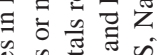

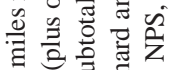

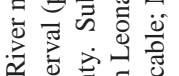
ف
异导

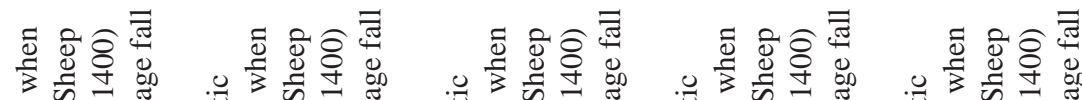

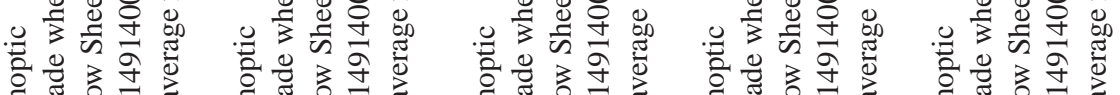

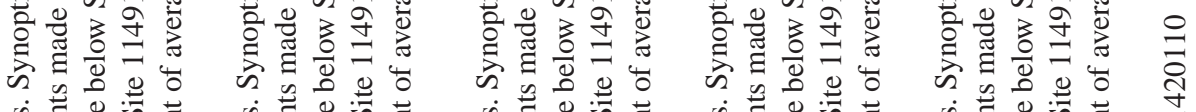

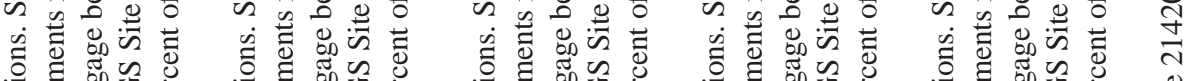

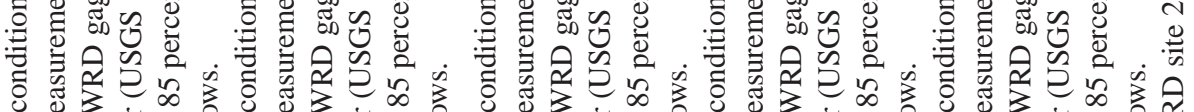

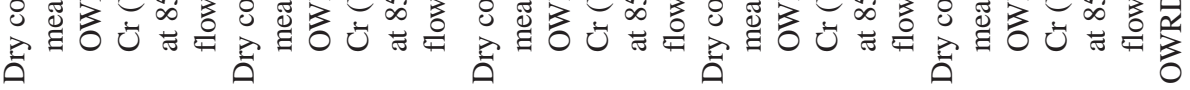

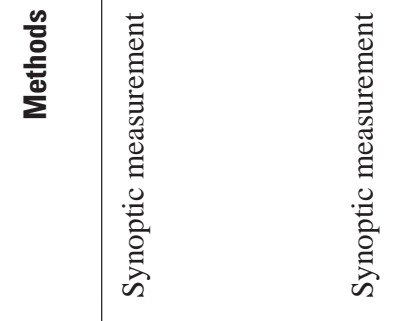

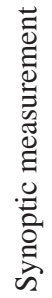

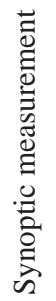

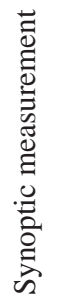

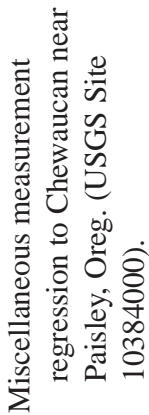

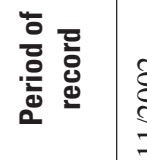

ڤั

๑ั

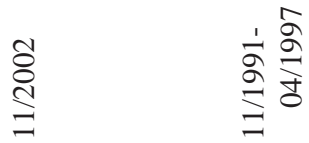

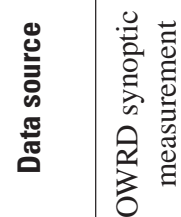

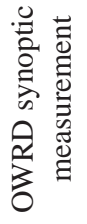

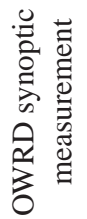

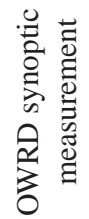

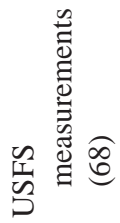

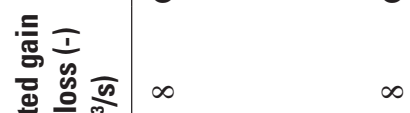

$\pm$

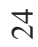

○

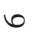

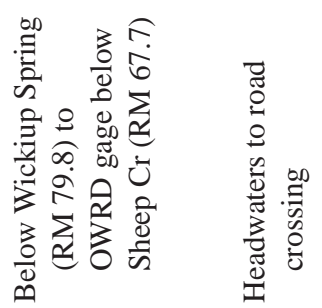

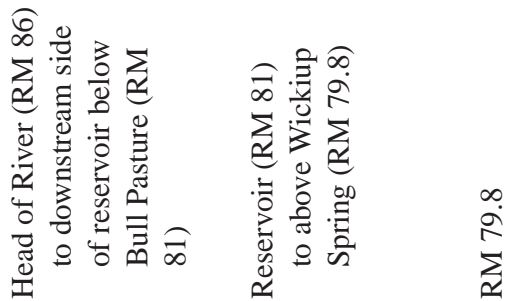

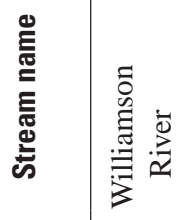

营

旁

赛

善

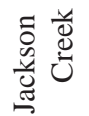

m

m

$\ddot{m}$

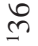

nิ 


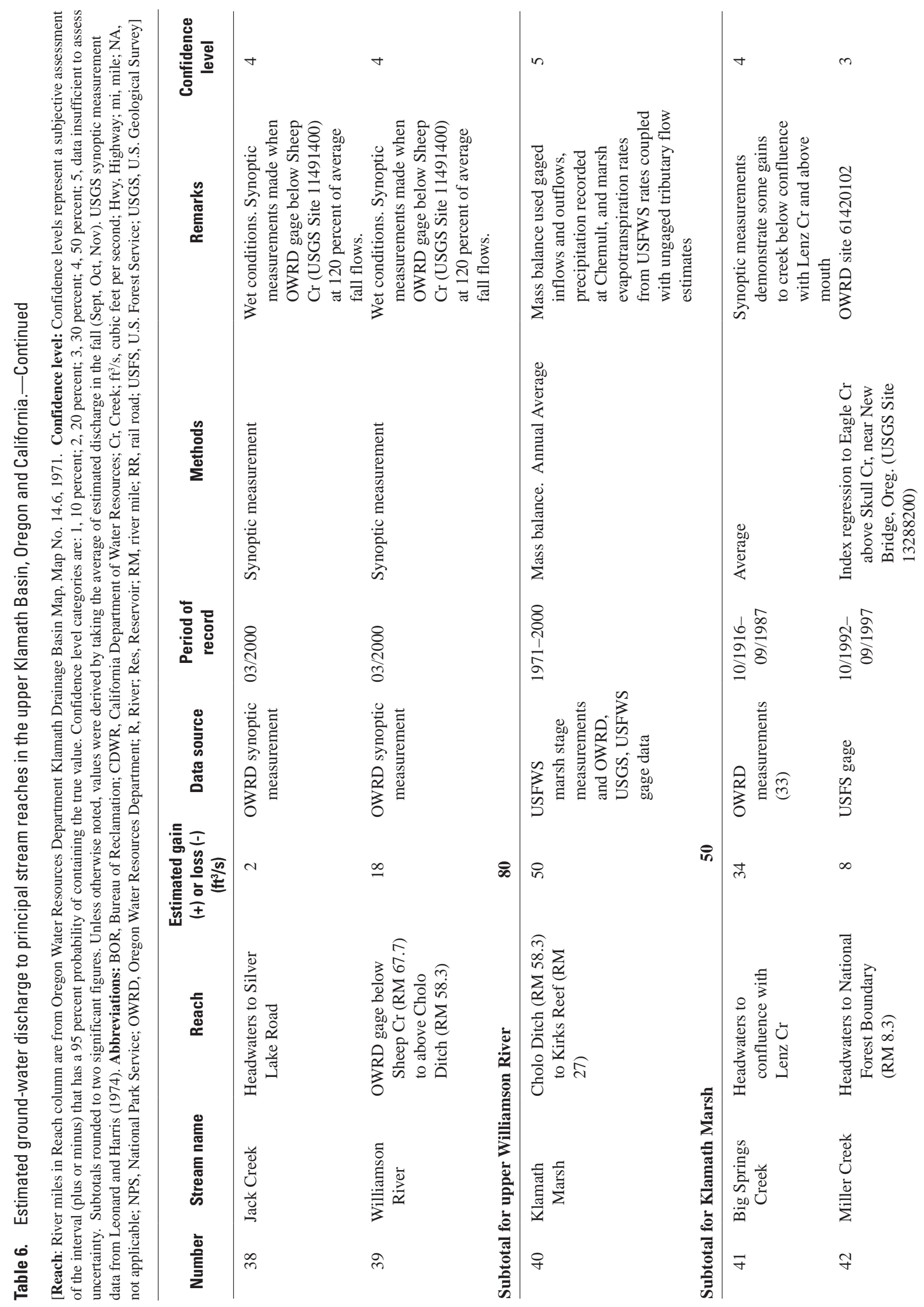


Table 6

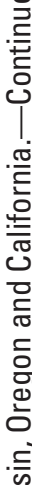

乒$$
\text { . }
$$

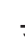

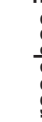

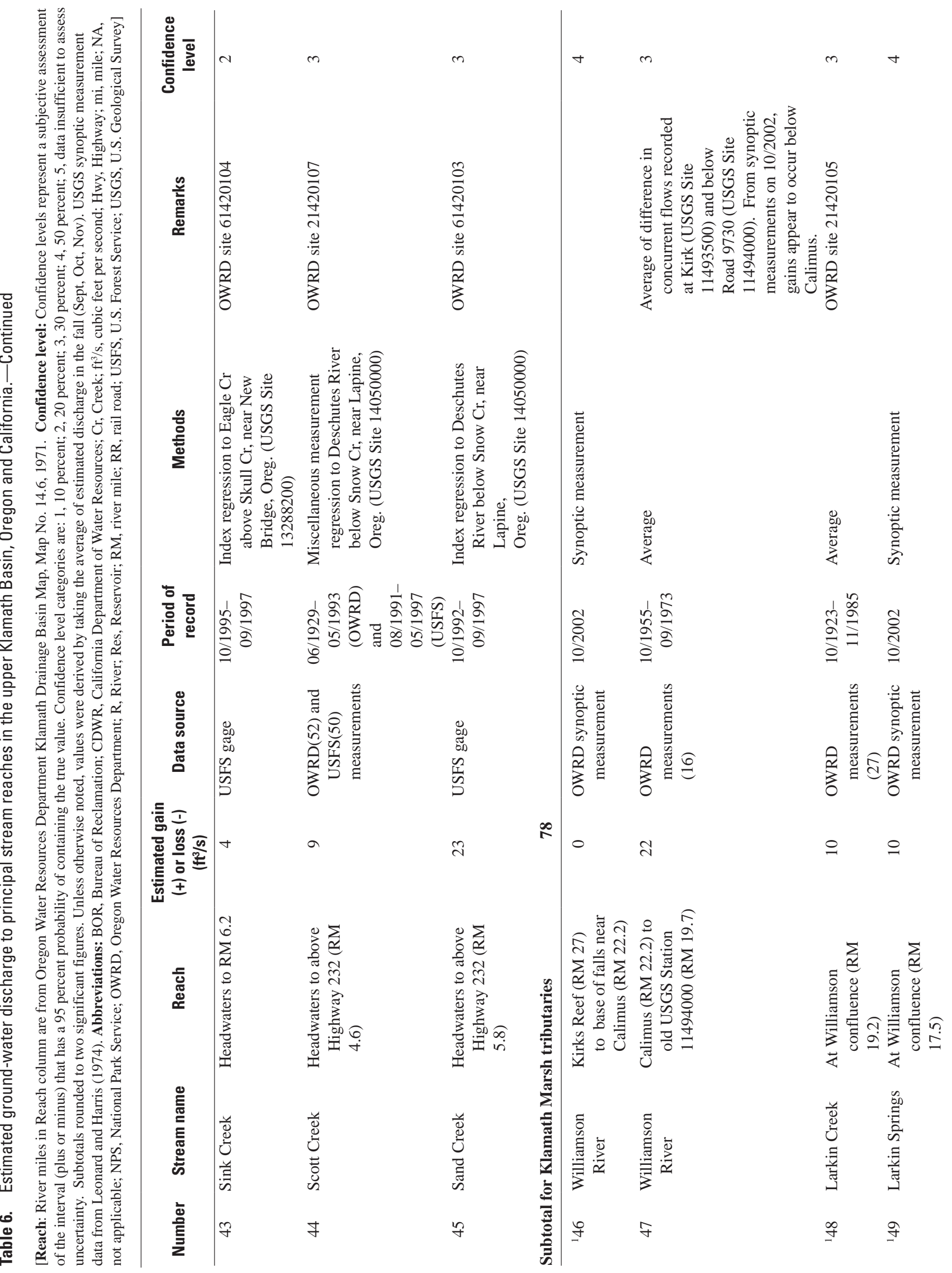




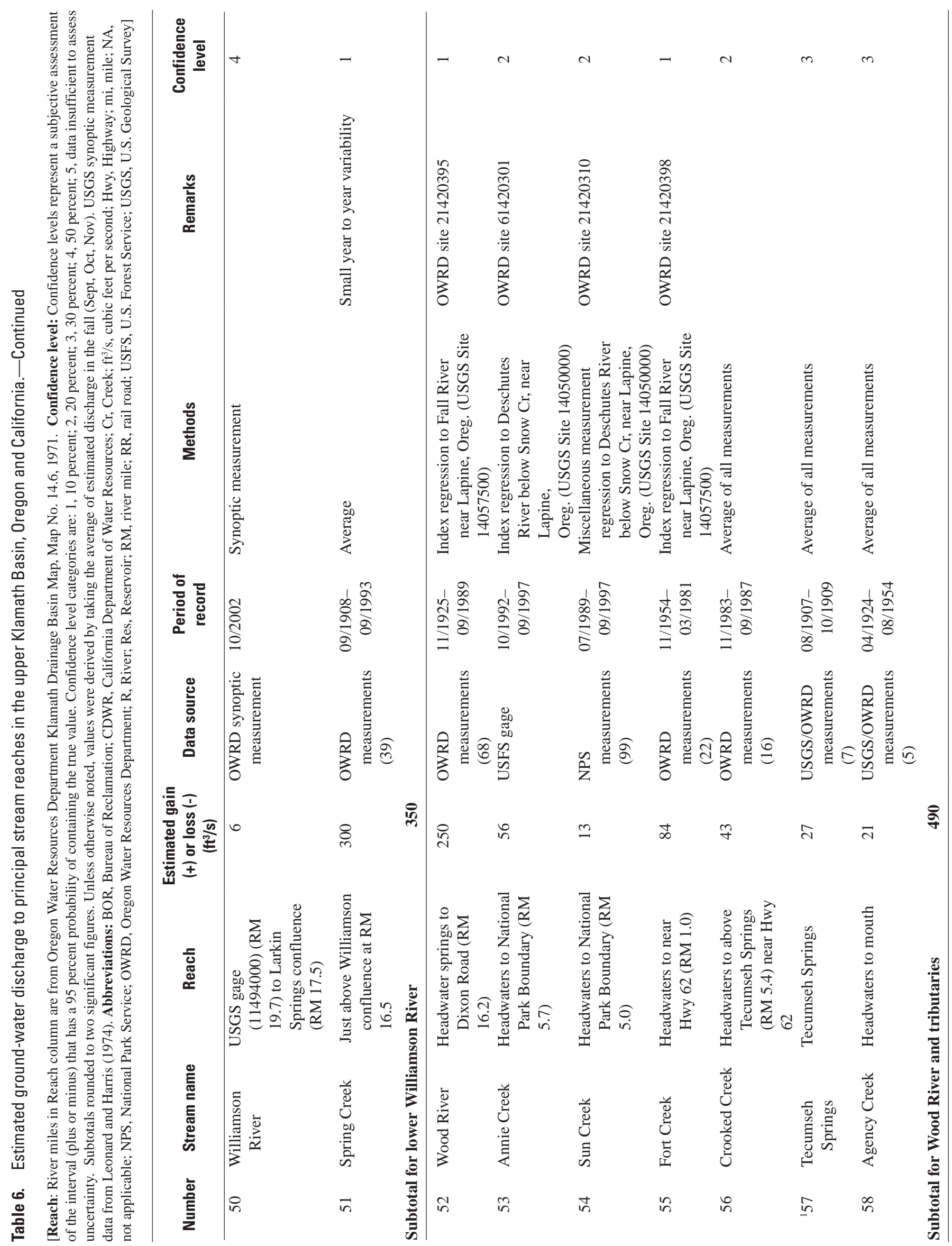


Table 6

81

皇

.

壱$$
\text { 政 }
$$

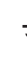

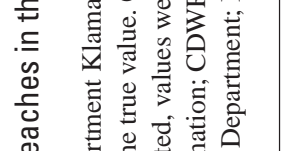

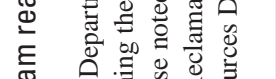

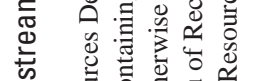

可

产

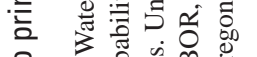

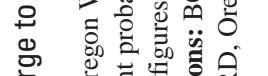

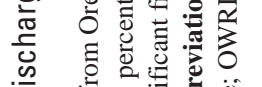

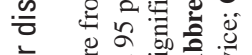

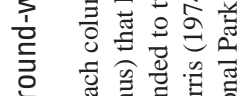

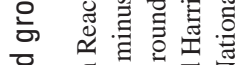

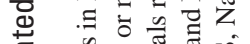

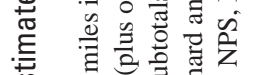

出

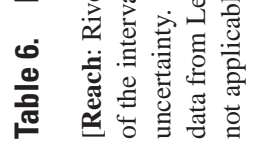

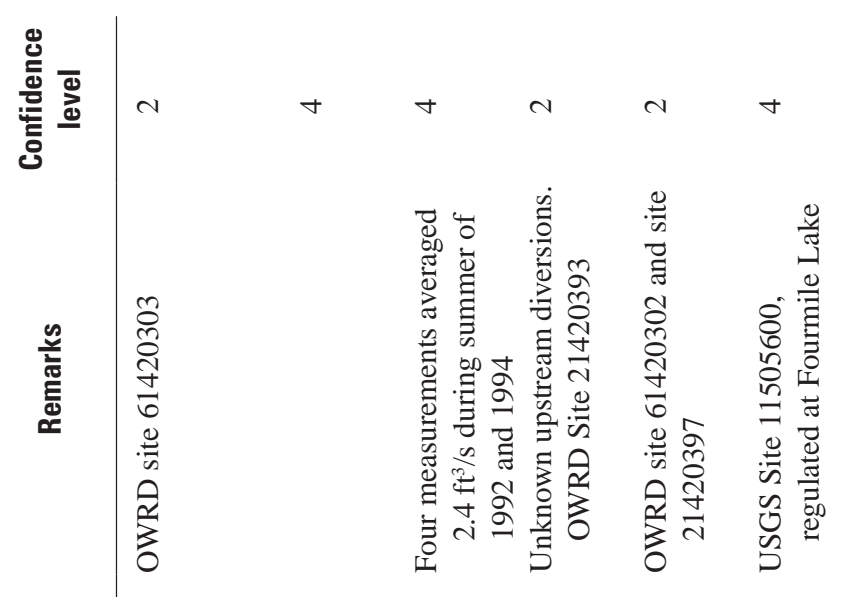

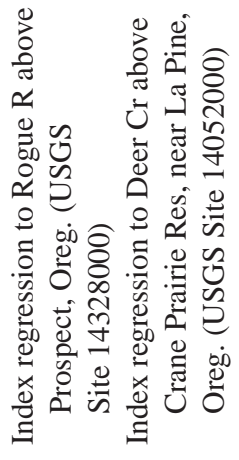

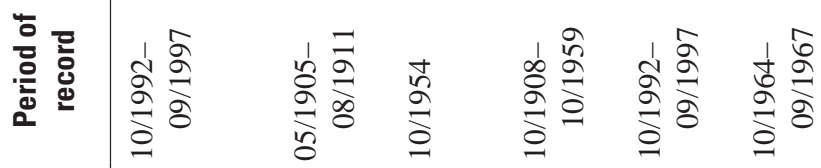

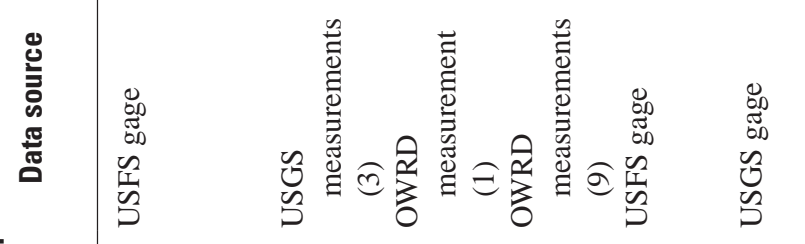

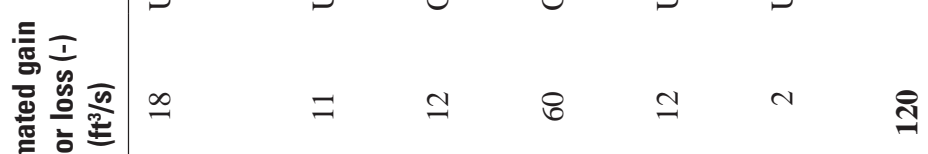

端王

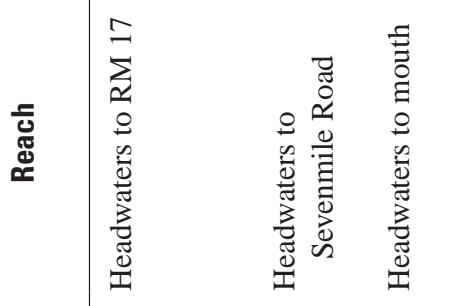

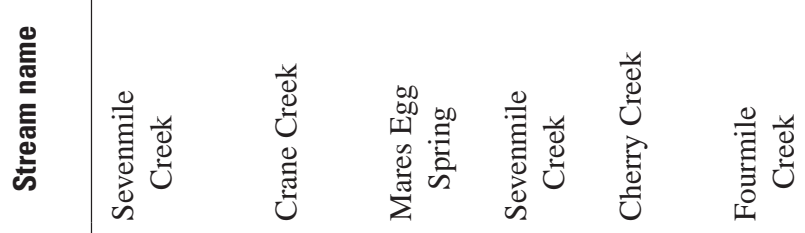

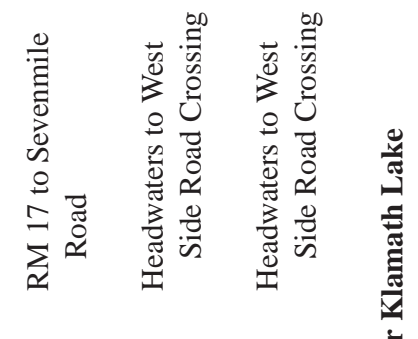

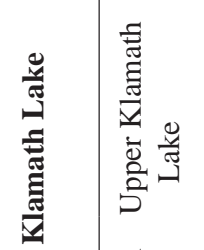

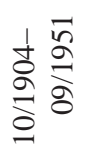

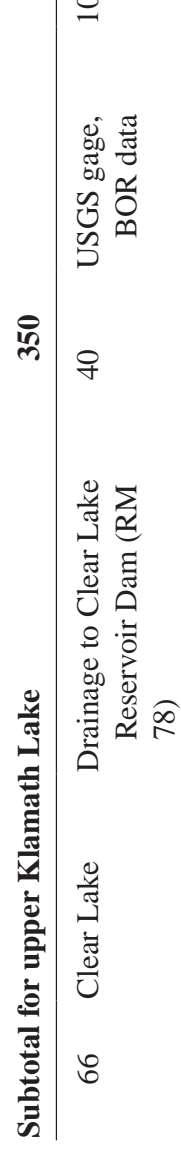




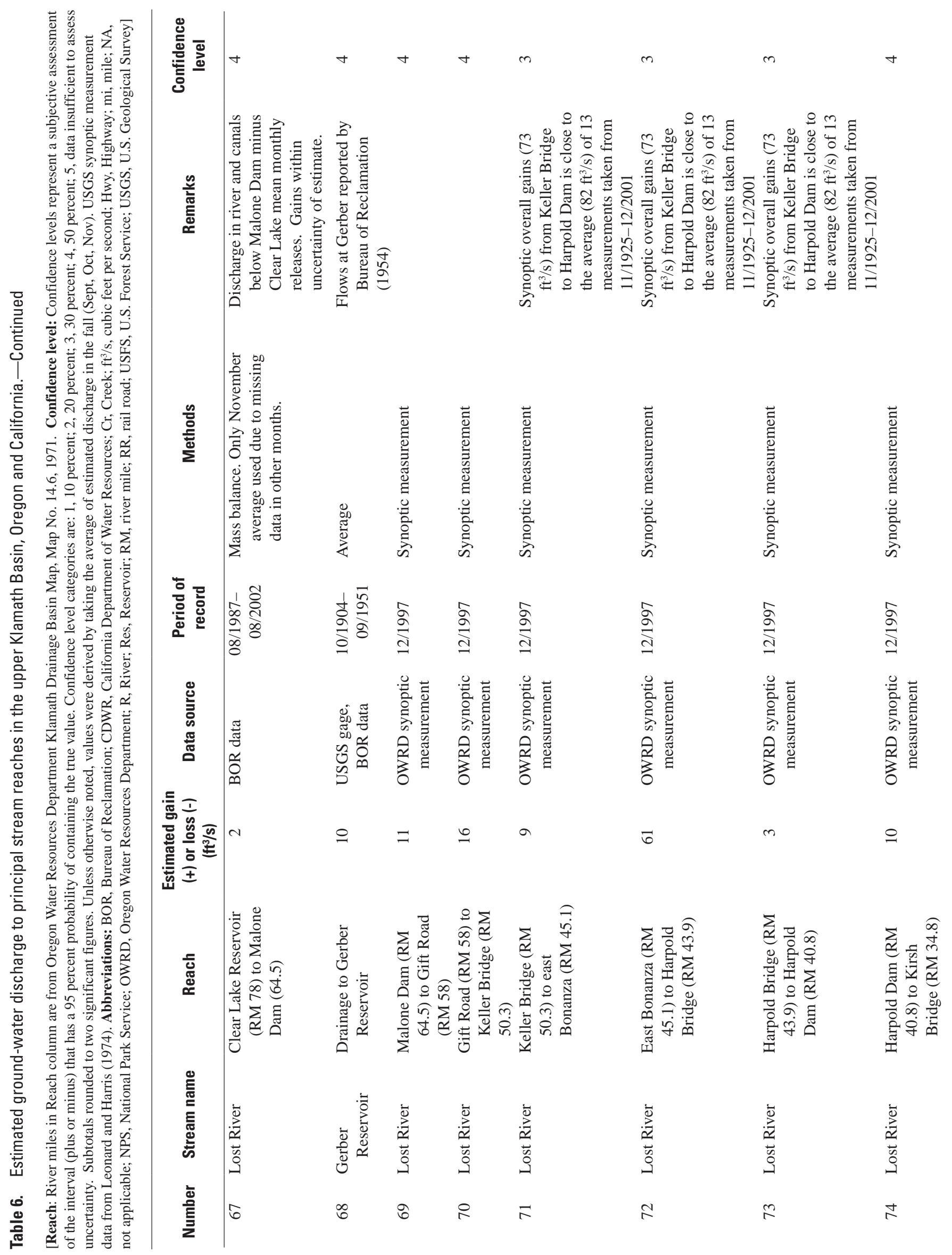




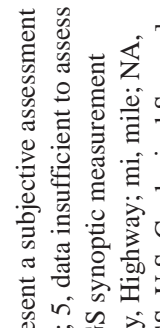

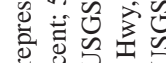

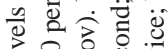

a in $z$

诺范岕

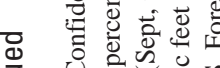

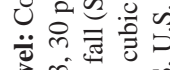

\&

잉

워 응 0

$\dot{1}=0$

근

记웡

安 -4 㟧

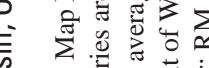

๑

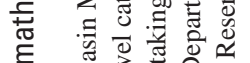

의.

ळ.

บ

芩号芆

क

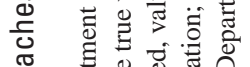

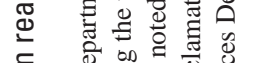

Е

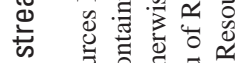

匹

U

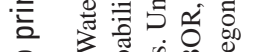

足

क्षे

品

过 可

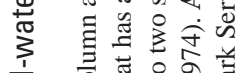

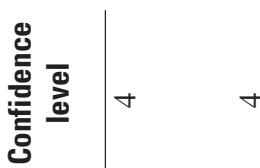

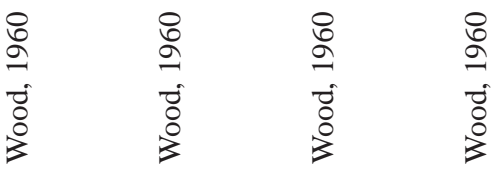

蛋
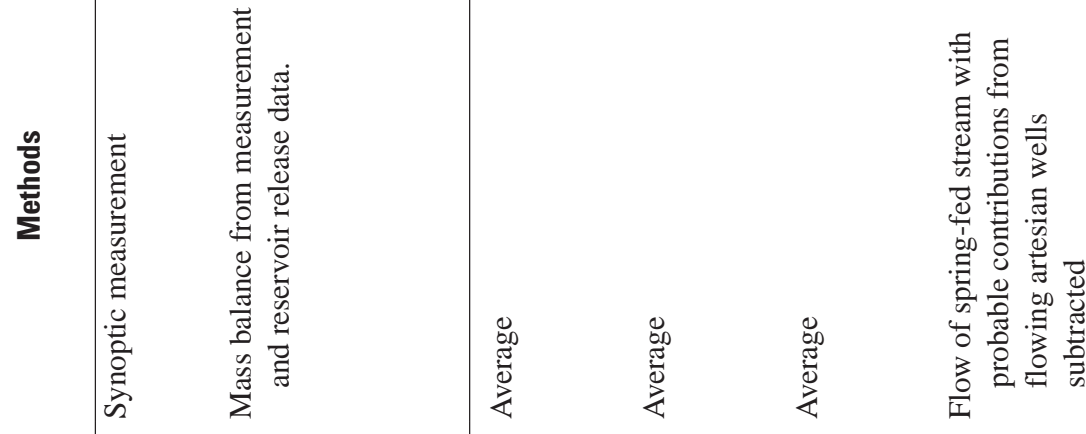

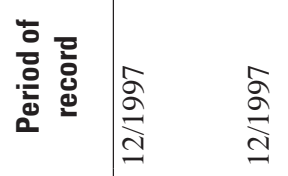

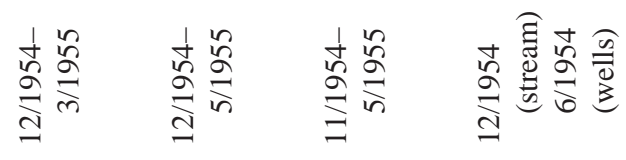

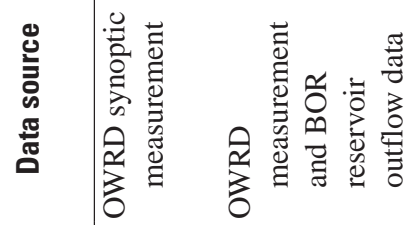

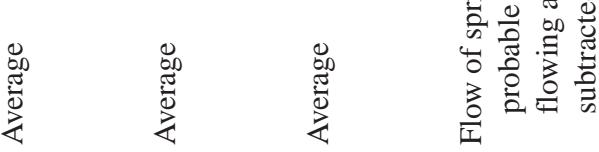

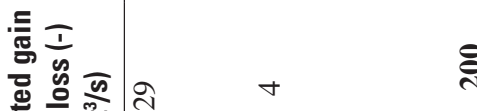

8

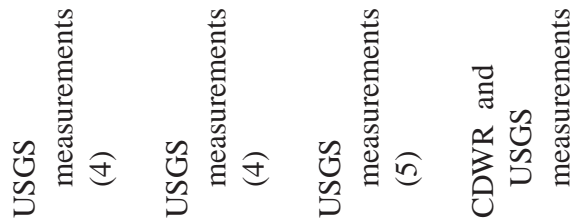

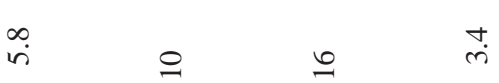

m

言

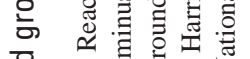

这

莺

을

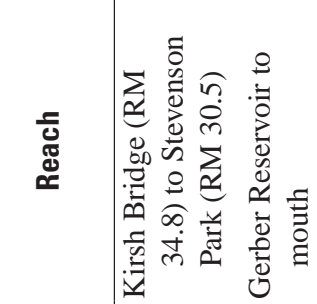

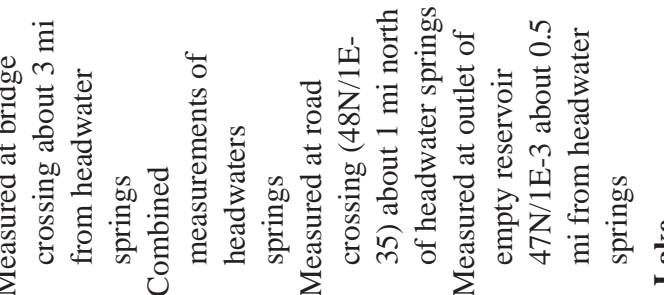

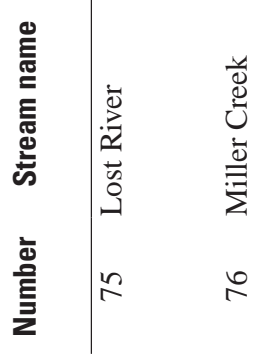

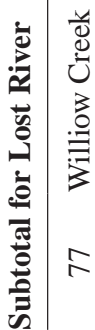

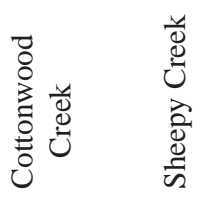

$\stackrel{\infty}{\sim}$

$\curvearrowright$

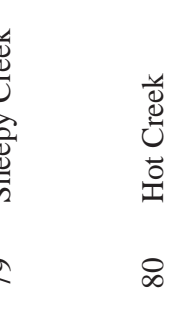

$\frac{4}{0}$ 


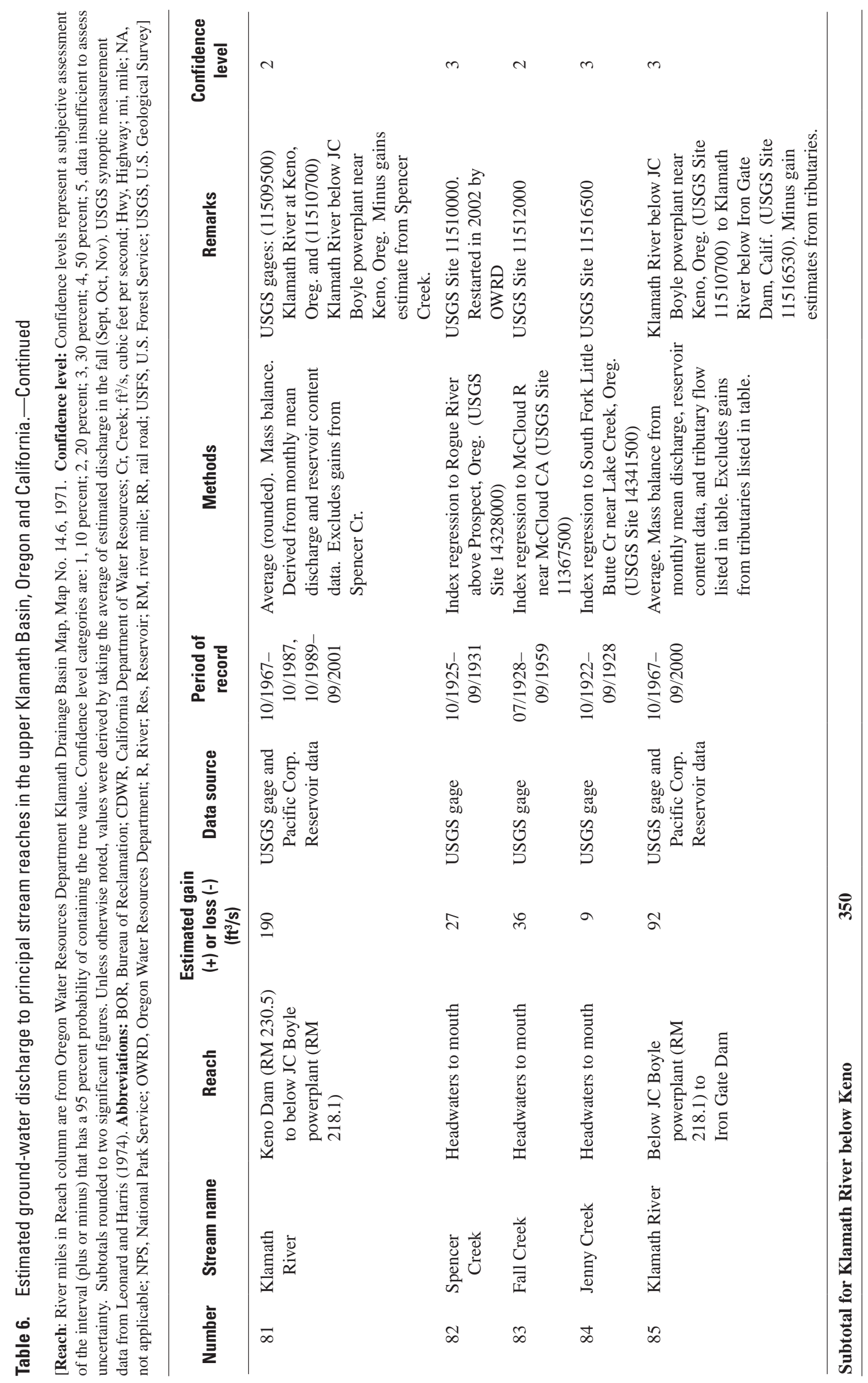


Manuscript approved for publication, April 4, 2007

Prepared by the USGS Publishing Network,

Publishing Service Center, Tacoma,

Bill Gibbs

Donita Parker

Linda Rogers

Debra Grillo

Ginger Renslow

Bobbie Jo Richey

For more information concerning the research in this report, contact the Oregon Water Science Center Director

U.S. Geological Survey

10615 S.E. Cherry Blossom Dr.

Portland, OR 97216

http://or.water.usgs.gov 
